\title{
EVOLUCIÓN [ESPACIO-TEMPORAL]
}

DE LA CIUDAD UNIVERSITARIA DE MADRID (1926-1956).

DIÁLOGOS ENTRE UNOS PROCESOS ARQUITECTÓNICOS DE CONFORMACIÓN

TESIS DOCTORAL
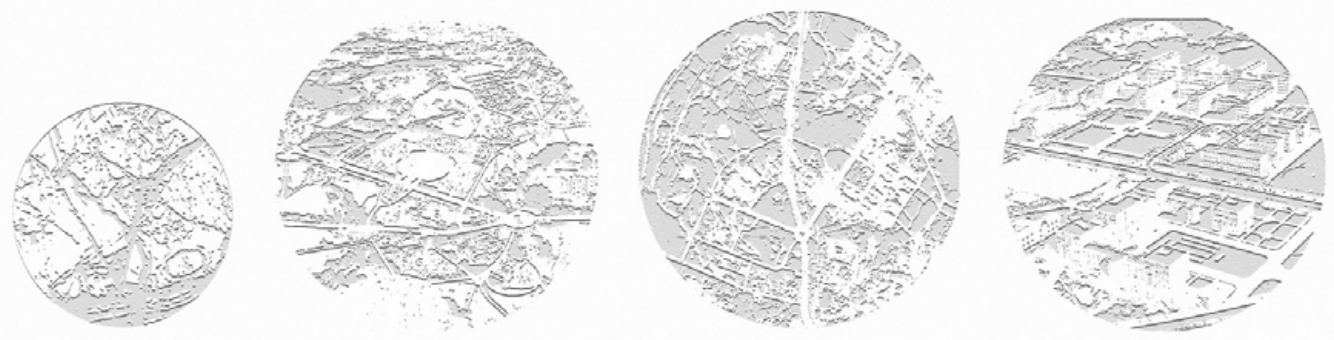

DOCTORANDO:

Cristina Romero de la Torre

CODIRECTORES:

Joaquín Ibáñez Montoya

Profesor Titular de Proyectos Arquitectónicos

ETSAM. Escuela Técnica Superior de Arquitectura de Madrid

Pablo Campos Calvo-Sotelo

Profesor Ordinario-Catedrático de Composición CEU. Centro de Estudios Universitarios - Arquitectura

Departamento de Proyectos Arquitectónicos. Escuela Técnica Superior de Arquitectura de Madrid. ETSAM UNIVERSIDAD POLITECNICA DE MADRID. UPM

GRUPO DE INVESTIGACIÓN: http://gipaisajecultural.dpa-etsam.com Paisaje Cultural. Intervenciones contemporáneas en la ciudad y el territorio PROGRAMA: 330A Teoría y Práctica del Proyecto. [RD778/1998] 

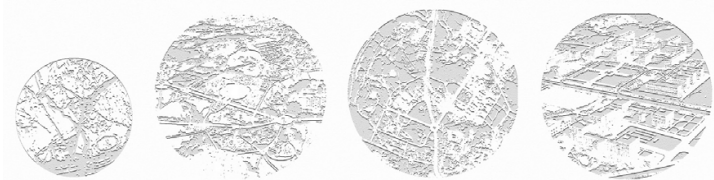

ESCUELA TÉCNICA SUPERIOR DE ARQUITECTURA DE MADRID. 
DEPARTAMENTO DE PROYECTOS ARQUITECTÓNICOS

ESCUELA TÉCNICA SUPERIOR DE ARQUITECTURA DE MADRID. ETSAM

EVOLUCIÓN [ESPACIO-TEMPORAL]

DE LA CIUDAD UNIVERSITARIA DE MADRID (1926-1956).

DIÁLOGOS ENTRE UNOS PROCESOS ARQUITECTÓNICOS DE CONFORMACIÓN

TESIS DOCTORAL

Cristina Romero de la Torre

Arquitecta.

2016 

DEPARTAMENTO DE PROYECTOS ARQUITECTÓNICOS

ESCUELA TÉCNICA SUPERIOR DE ARQUITECTURA DE MADRID. ETSAM

\section{EVOLUCIÓN [ESPACIO-TEMPORAL]}

DE LA CIUDAD UNIVERSITARIA DE MADRID (1926-1956).

DIÁLOGOS ENTRE UNOS PROCESOS ARQUITECTÓNICOS DE CONFORMACIÓN

TESIS DOCTORAL

Joaquín Ibáñez Montoya

ETSAM. Escuela Técnica Superior de Arquitectura de Madrid

Pablo Campos Calvo-Sotelo

CEU. Centro de Estudios Universitarios - Arquitectura

\section{Codirectores}



D.12

Tribunal nombrado por el Mgfco. Y Excmo. Sr. Rector de la Universidad Politécnica de Madrid, el día

Presidente D.

Vocal D.

Vocal D.

Vocal D.

Secretario D.

Realizado el acto de defensa y lectura de Tesis el día

en la Escuela Técnica Superior de Arquitectura de Madrid

Calificación:

EL PRESIDENTE

LOS VOCALES 



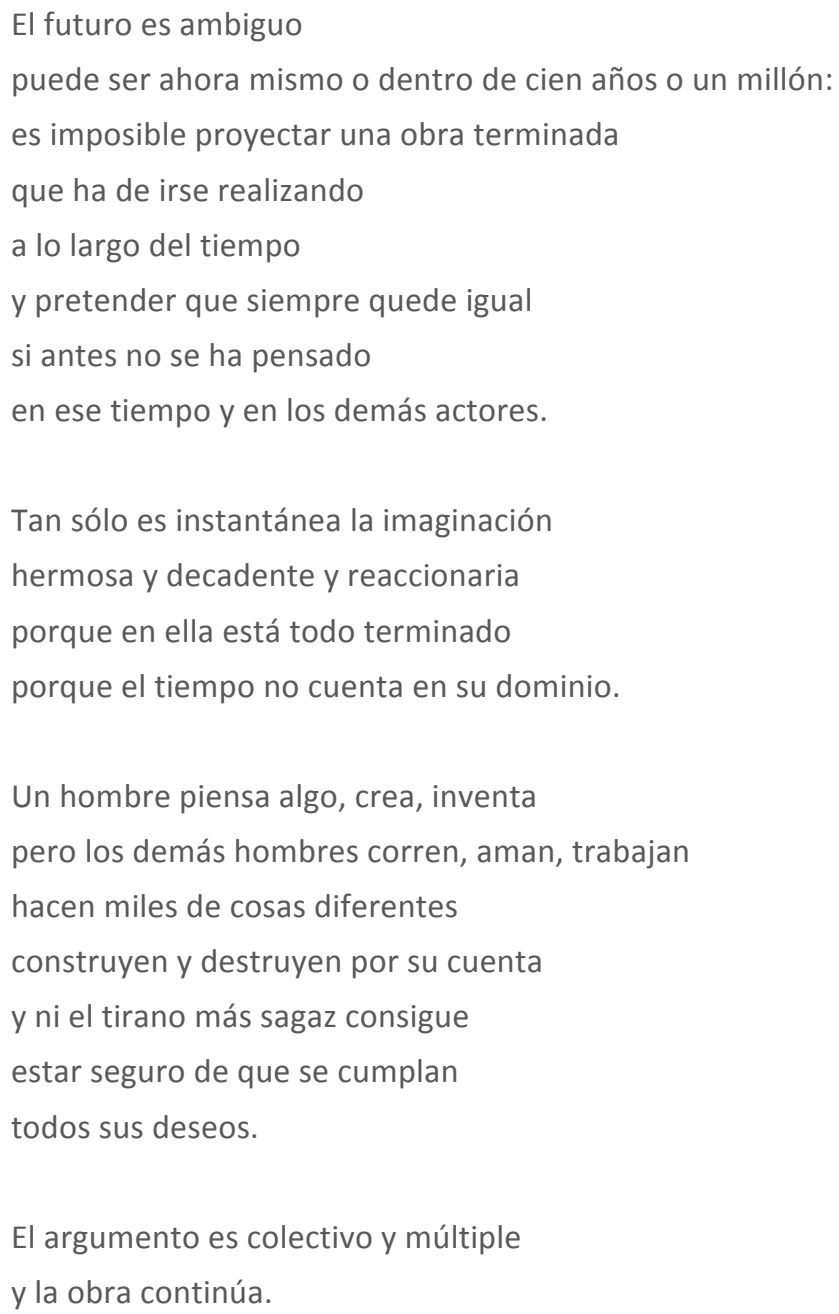




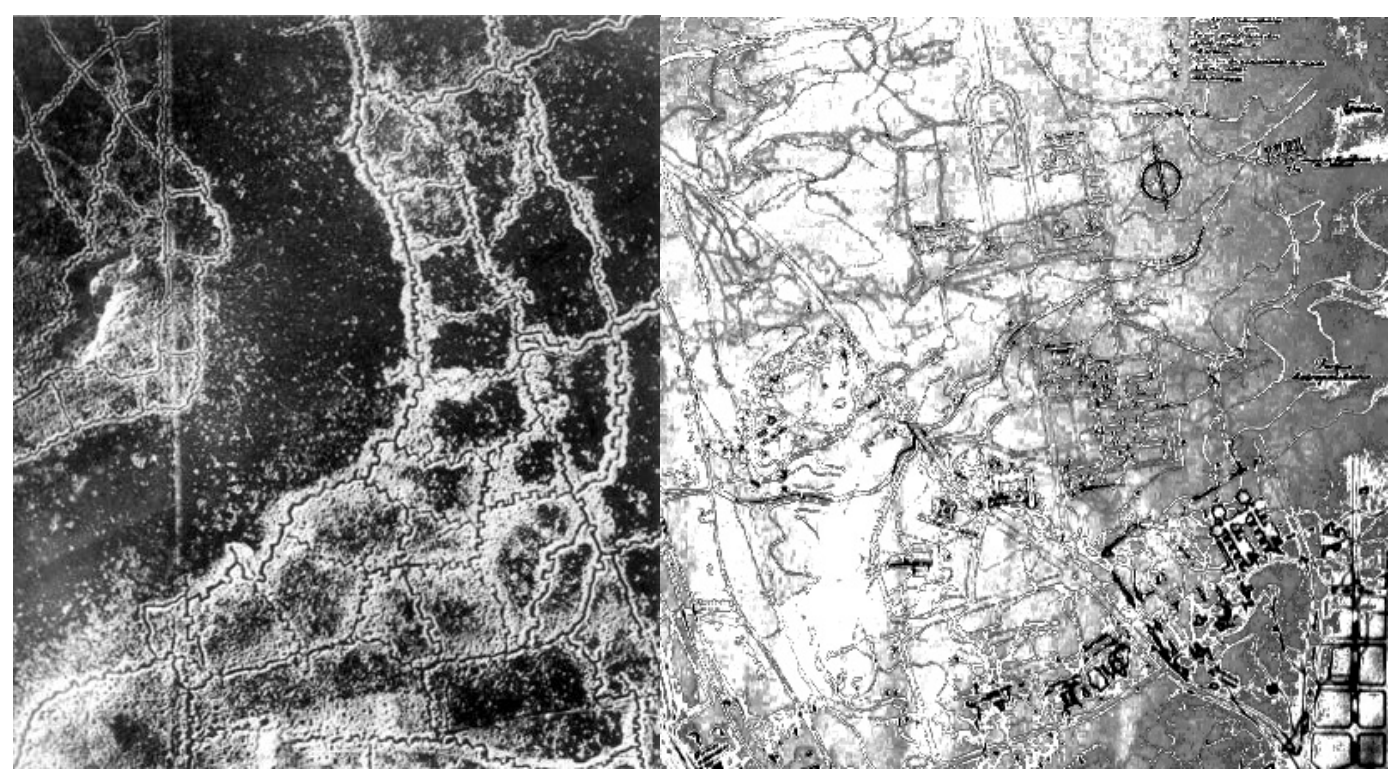

Vista aérea del sistema de trincheras de la zona de Loos-Hulluch.Pas de Calais, Julio de 1917. Vista aérea primeras líneas y terreno comprendido en las panormicas.La Ciudad Universitaria. Madrid, 1939. 


\section{RESUMEN}

Abstract

Ideas esenciales

Hipótesis

Agradecimientos

\section{INTRODUCCIÓN}

Preámbulo. Intención y objetivos

El arquitecto que estudia y analiza un LUGAR

\section{MATERIAL Y MÉTODO}

El método de estudio y el material para el desarrollo

La Ciudad Universitaria de Madrid como ÁMBITO DE ESTUDIO [espacio]

La visión panorámica del PASADO desde el PRESENTE [tiempo]

Justificación de la elaboración del estudio en el contexto actual

Fuentes primarias y secundarias

III. DESARROLLO

Organización del documento en capítulos

$\begin{array}{ll}\text { cap1- LUGAR _ } & \text { Contexto/ [LO CONTEXTUAL] / Espacio-Tiempo } \\ \text { cap2- FORMA_ } & \text { Temático/ [LO JUSTIFICADO] / Génesis } \\ \text { cap3- FÍSICO _ } & \text { Temático/ [LO AJENO] / Transformación } \\ \text { cap4- CONCEPTO _ } & \text { Temático/ [LO PROPIO]/Distorsión } \\ \text { ANEXOS } & \text { Contexto/ Marco Complementario }\end{array}$

IV. CONCLUSIONES

V. FUENTES y BIBLIOGRAFÍA

Bibliografía y Archivos 

ÍNDICE Abreviado

\author{
RESUMEN - Abstract \\ I. INTRODUCCIÓN \\ II. MATERIAL Y MÉTODO \\ III. DESARROLLO
}

ANCESTROS

cap1 _ LUGAR [LO CONTEXTUAL] _ Espacio-Tiempo

p. 3

c.1.1_ La mirada, la memoria y el lugar.

La Intención, el espacio-tiempo y el significado

c.1.2_ Duo-polis- Sintaxis entre dos ámbitos. Ciudad como fachada

c.1.3_ Laboratorio social- político - urbano de Madrid

c.1.4_ La reparcelación de la CUM.

p0-Maclas , Límites y Continuidad

PROCESOS

Cap2 _ FORMA [LO JUSTIFICADO]_ Génesis

c.2.1_ Un grupo heterogéneo para un proyecto unitario. Ideales importados para una nueva Universidad.

c.2.2_ Ciudades del Saber. El escenario urbano-universitario.

c.2.3_ Planeamiento de un proyecto a diferente escala

c.2.4_ Procesos de Génesis

p1- Ejes y Estructura_ p2- Llenos y Vacíos_ p3- Perspectivas y Relaciones

cap3 _ FÍ́SICO [LO AJENO]_ Transformación

p. 139

c.3.1_ Escuelas de la mirada.

Un paisaje bélico - arquitectónico

c.3.2_ Metamorfosis del campus de Madrid

c.3.3_ Doble línea y tierra de nadie

c.3.4_ Procesos de Trasformación

p4.Muros y Visuales_p5.Posiciones y Nodos_ p6.Perforaciones y Horadaciones

cap4 _ CONCEPTO [LO PROPIO]_ Distorsión

p. 199

c.4.1_ Ruinas y Sentimiento.

Reconstrucción e Ideología

c.4.2_ Maquetas. Apariciones y Ausencias

c.4.3_ Procesos de Distorsión

p7- Dualidades _p8- Escenografías _ p9- Articulaciones

c.4.4_ El paisaje posterior y la proyección de los paisajes futuros

ANEXOS

p. 269

IV. CONCLUSIONES

V. FUENTES Y BIBLIOGRAFÍA 
ÍNDICE Descriptivo

\author{
RESUMEN. Abstract \\ I. INTRODUCCIÓN \\ II. MATERIAL Y METODO \\ III. DESARROLLO
}

\title{
ANCESTROs
}

cap1 _ LUGAR [LO CONTEXTUAL] _ Espacio-Tiempo

$\begin{array}{lll}\text { c.1.1_ La mirada, la memoria y el lugar } & \text { p. } 4\end{array}$

La Intención, el espacio-tiempo y el significado p.11

c.1.2_ Duo-polis- Sintaxis entre dos ámbitos. Ciudad como fachada p.15

$\begin{array}{ll}\text { c.1.2.1_La metrópoli de principios de siglo p.17 } & \text { p.17 }\end{array}$

c.1.2.2_Zona de ensanche de Madrid. Ciudad griega/latina p.21

c.1.3_ Laboratorio socio- político - urbano de Madrid p.23

$\begin{array}{ll}\text { c.1.3.1_El origen de algo justificado p.27 } & \text { p.23 }\end{array}$

c.1.3.2_El conflicto del primer proyecto p.35

c.1.4_ La reparcelación de la CUM p.39

p0-Maclas , Límites y Continuidad_(Unificación) p.41

\section{PROCESOs}

cap2 _ FORMA [LO JUSTIFICADO]_ Génesis

c.2.1_ Un grupo heterogéneo para un proyecto unitario. p.70

Ideales importados para una nueva Universidad. p.75

c.2.2_ Ciudades del Saber. El escenario urbano-universitario p.83

c.2.2.1_Concepto de Campus en la Ciudad Universitaria de Madrid p.86

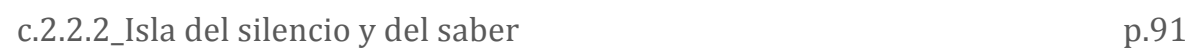

$\begin{array}{lll}\text { c.2.3_ Planeamiento de un proyecto a diferente escala } & \text { p.95 }\end{array}$

c.2.3.1_Composición urbana y planimetría p.97

c.2.3.2_Proyecto realizado por grupos y por fases p.103

$\begin{array}{ll}\text { c.2.4_ Procesos de Génesis } & \text { p.107 }\end{array}$

p1- Ejes y Estructuras _ [Infraestructura /Vaciados /Cornisas] p.109

p2- Llenos y Vacíos _ [Escala /Contenedores/ Material] p.114

p3- Perspectiva y Relaciones _ [Zonificación/Naturaleza] p.127 
cap3 _ FÍSICO [LO AJENO] _ Transformación

$\begin{array}{lrr}\text { c.3.1_ Escuela de la mirada } & \text { p.140 }\end{array}$

$\begin{array}{lr}\text { Un paisaje bélico - arquitectónico } & \text { p.144 }\end{array}$

c.3.2_ Metamorfosis del campus de Madrid p.151

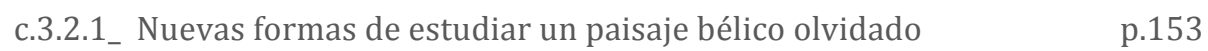

$\begin{array}{lr}\text { c.3.2.2_ Lugares estratégicos, tácticos y logísticos p.157 } & \text { p }\end{array}$

c.3.3_ Doble línea y Tierra de nadie p.161

c.3.3.1_Fisonomía territorial. Fragmentación del suelo p.165

c.3.3.2_Fisonomía arquitectónica. Exterior de las construcciones p.168

c.3.4_ Procesos de Trasformación $\quad$ p.171

p4. Muros y Visuales_[Movimientos de Yuxtaposición] p.172

p5. Posiciones y Nodos _ [Injertos de Estrategia] p.182

p6. Perforaciones y Horadaciones _ [Cicatrices de Comunicación] p.186

cap4 _ CONCEPTO [LO PROPIO] _ Distorsión

$\begin{array}{llr}\text { c.4.1_ Ruinas y Sentimiento p.200 } & \text { p. }\end{array}$

$\begin{array}{lr}\text { Reconstrucción e Ideología } & \text { p.207 }\end{array}$

$\begin{array}{ll}\text { c.4.2_ Maquetas. p.219 } & \text { p. }\end{array}$

$\begin{array}{lr}\text { Apariciones y Ausencias } & \text { p.223 }\end{array}$

c.4.3_ Procesos de Distorsión p.229

$\begin{array}{lr}\text { p7. Dualidades _ [Fragmentaciones y nuevos usos] } & \text { p.230 }\end{array}$

p8. Escenografías _ [Adoctrinamiento y Publicidad] p.239

$\begin{array}{lr}\text { p9. Articulaciones _ [Entrada y salida] } & \text { p.242 }\end{array}$

c.4.4_ El paisaje posterior y la proyección de los paisajes futuros p.253

ANEXOs

Anexo c1_Momento arquitectónico en España. La Arquitectura Moderna p.271

Anexo c2_La Universidad y su desarrollo histórico. El Viaje de la nueva realidad p.281

Anexo c3_Fortificaciones permanentes y de campaña. Madrid Fortificada p.305

Anexo c4_Construcciones en época del Régimen p.319

CUADRO I : Periodos de Ancestros y Procesos $\quad$ p.321

CUADRO II: Recintos universitarios $\quad$ p.323

CUADRO III: Edificaciones-CR/SZ - Minas y Contraminas p.325

DIALOGOS: Miradas_Fotografías. p.333

DIALOGOS: Memoria_Escritos y Entrevista. $\quad$ p.339

IV. CONCLUSIONES p.349

V. FUENTES y BIBLIOGRAFÍA

$\begin{array}{lr}\text { Fuentes. Archivos consultados } & \text { p.357 }\end{array}$

$\begin{array}{lr}\text { Bibliografía comentada y específica } & \text { p.358 }\end{array}$ 



\section{RESUMEN}

El presente trabajo tiene como objeto de estudio el recinto de La Ciudad Universitaria de Madrid entendido como un proyecto urbano y arquitectónico unitario, con la finalidad fundamental de establecer la relación directa entre su diseño pasado original a través de su desarrollo proyectual arquitectónico secuencial, sedimentario o superpuesto, y la reinterpretación actual de nuevos significados o valores que laten, que se esconden o están subyacentes en su proceso de conformación de su diseño vigente.

Se analiza en más profundidad el período comprendido entre 1926 y 1956, empezando a nivel contextual por los ancestros, y así posteriormente aplicar el proceso, objeto de este estudio; proceso que se subdivide en tres fases (asociados a cada uno de los tres capítulos) para así identificar los posibles mecanismos de manipulación del lugar, que se ha generado dejando un rastro sobre éste. Se centra la mirada, más concretamente, en la zona que mayor carga proyectual ha sufrido en el recinto universitario, tanto durante su ideación y construcción como durante la confrontación bélica entre 1936 y 1939; siendo la doble línea del frente, la llamada "tierra de nadie" (Nonesmanneslond- No man's land) la parte analizada como una nueva aportación proyectual singular de la investigación.

La esencia de esta investigación, el eje, es la creación de una nueva "complejidad analítica y re-interpretativa“; es la creación de un proceso continuo en espacio y tiempo en un ámbito concreto, tomándolo como caso de estudio. Según el concepto tradicional de los lugares, estos adquieren profundidad e individualidad con el paso del tiempo y en ellos se entremezclan y se funde substratos de diferentes concepciones proyectuales, urbanísticas o arquitectónicas, en el caso de "la Universitaria", que terminaron confluyendo en uno de los mejores recintos universitarios europeos de principios de siglo XX. Las posibles referencias a épocas pasadas desde las preexistentes, a través de su evolución o cambios, hace que hasta cierto punto se esté convencido de que estos procesos que lo han conformado, tienen una razón de ser, que han sido validados y que son un motivo adecuado para que definan su propia identidad. Este trabajo intenta recrear esa convicción sobre la evolución de un espacio proyectado único; ex-novo, al mismo tiempo que ofrece un mecanismo para ordenar y encapsular un proyecto arquitectónico, urbanístico y paisajístico lleno de complejidades, por medio de un análisis que se desarrolla en un ámbito concreto en el seno de una ciudad anexa a Madrid.

Un lugar, en fin, aglutinador de memoria, conservador de procesos proyectuales y ejemplo de materialidades, naturalezas y espacios. 


\section{ABSTRACT}

This paper aims to study the grounds of the Ciudad Universitaria de Madrid (The University City of Madrid), understood as an urban planning and architectural design unit, with the main purpose of establishing the direct relationship between its original design, through its architectural project development, whether sequential, sedimentary or superimposed, and the current reinterpretation of new meanings and values that are alongside, hidden in or underlying the process of conformation with its current design.

The period between 1926 and 1956 is discussed in more depth, starting at the contextual level with the ancestors, and then applying the process that is the object of this study; the process is divided into three phases (associated with each of the three chapters) in order to identify possible mechanisms of manipulation of the place that have been generated and which have left their traces on it. It focuses more specifically in the area that has undergone the greatest design load on campus, both during initial design and construction and during the military confrontation between 1936 and 1939; being the double front line, the "no man's land" (Nonesmanneslond), the part analysed as a new singular design contribution in the research.

The essence of this research axis is the creation of a new "re-analytical and interpretive complexity"; It is the creation of a continuum in space and time in a particular area, taking it as a case study. According to the traditional concept of places, they acquire depth and individuality with the passage of time and substrates of different projectual, urban planning or architectural conceptions mixing and melting together in them, and in the case of "the University" they ended up coming together into one of the best European campuses of the early twentieth century. The possible references to periods in the past from the pre-existing environment, through evolution or changes, mean that to some extent one is convinced that these processes that have shaped it have a rationale, have been validated and are an adequate reason to say they define its identity. This paper attempts to recreate that belief in the evolution of a unique designed space: exnovo, while at the same time providing a mechanism to organise and encapsulate an architectural, urban planning and landscape project full of complexities, through an analysis that takes place in a specific area within a city adjacent to Madrid.

A place, in short, agglutinating memory, conserving project processes and an example of materialities, natures and spaces. 


\section{IDEAS ESENCIALES.}

Procesos conformadores de forma, físicos y conceptuales que configuran el lugar. Se realiza un recorrido conceptual acumulativo a través de diversas capas o estratos que reflejan la alteración que ha sufrido La Ciudad Universitaria; para así conseguir una ordenada o simplificada clasificación de procesos [mecanismos] que sienten las bases para interpretar cualquier otra intervención futura o de lugares de similares características. Es decir, el objetivo, no es tanto hacer una clasificación de las etapas más relevantes que dieron origen al proyecto de La Ciudad Universitaria de Madrid, sino descubrir la estructura, el orden, y la taxonomía de este lugar con una mirada crítica, analítica y actual que permita reinterpretar cualquier decisión proyectual, arquitectónica o urbanística, tanto del pasado como del futuro. Un análisis o mirada temporal-espacial de un proyecto.

"Una mirada hacia atrás vale más que una hacia adelante"—-Arquímedes

Las formas, la memoria y la mirada están relacionadas. En una disciplina como la Arquitectura, la mirada posee una intención, la memoria acota un espacio de tiempo determinado y las formas del lugar poseen significados que se podrían analizar y reinterpretar.

El estudio, el trabajo del arquitecto (tal como yo lo veo) están condicionados por su mirada particular, por su mirada propia, por la memoria intrínseca y por el lugar escogido. Este trabajo está hecho por estratos donde las ideas, los conceptos y la historia, los objetos y los edificios, los planos, las visitas, las fotografías y los textos bibliográficos construyen una sección, un palimpsesto de profundidad variable. Tiene un valor que se obtiene tanto de su acumulación, ordenación y clasificación como de la elaboración de cada uno de los procesos independientes que conforman esos estratos diferenciados. Tanto la sección como cada una de las agrupaciones de esas capas son "encapsulamientos" de un proyecto mayor, que iluminan y generan el trabajo de ir encajando las piezas para conformar el discurso que se ha pretendido encontrar y explicar en esta tesis. Para un arquitecto los edificios y sus espacios anexos -los lugares- tienen a veces la virtud de hablarnos con claridad y facilidad, sin intermediarios, puesto que prescinden de una interpretación más crítica o banal, para llegar a reconocerles algún valor espacial, formal, o bien materializar con ellos la abstracción más inverosímil y convertirse así en referencias cuando proyectamos otros.

Para llegar a este fin, de nuevos significados en el lugar, se genera una mirada, por medio de un análisis, relacionando conceptos para encontrar esos "procesos generadores" del proyecto arquitectónico que asienta las bases de este lugar en concreto, dando una respuesta a esos posibles vacíos existentes, significados desaparecidos y valores únicos que se intuían que estaban en este lugar. Lugar ya estudiado y explicado anteriormente, pero utilizando esta vez un nuevo análisis científico, arquitectónico y mas contemporáneo, con la intención de sumar nuevas lecturas o "miradas" a lo ya explicado.

La Ciudad Universitaria de Madrid funciona como un conjunto de edificaciones, facultades y escuelas que son un todo, compuesto por individualidades en un lugar que se modifica, a la vez que se trasforma el terreno que las contiene, conformando el estrato base de ese lugar. 
Todos estos elementos arquitectónicos, que han sido testigos de diversos eventos y procesos proyectuales de evolución quedan marcados, no solo por sí mismos, sino por el valor que tuvieron en el proyecto inicial, su trasformación o desaparición y su posterior reconstrucción. Se convierte en un lugar conformado, en un conjunto arquitectónico, de valores diferentes al resto que habría que investigar para poder demostrar, con la mezcla de nuevos y antiguos métodos de análisis, la búsqueda y aparición de nuevos intereses y reinterpretaciones.

“Las dos miradas al cruzarse tuvieron un breve e instantáneo diálogo"1

la mirada __ posee una intención

la memoria _ acota un espacio de tiempo

las formas del lugar ___ poseen significados

\section{HIPÓTESIS}

La mirada a un lugar se establece desde unas determinadas premisas, que se presentan en el cuadro a continuación:

PROYECTO ENCAPSULADO EN EL [LUGAR], ESPACIOS, ARQUITECTURA Y MATERIALIDAD.

1-Es posible encapsular un proyecto arquitectónico en un lugar, tiempo y visión, como ocurrió en las diferentes etapas de la creación de la Ciudad Universitaria de Madrid.

\section{TERMINOLOGÍA [ESPACIO/TIEMPO] DE DIFERENTES PROCESOS PROYECTUALES}

2-Los lugares o construcciones, testigos-marcados por un proceso evolutivo y secuencial, pueden ser analizados y valorados paisajística y arquitectónicamente bajo puntos de vista diferentes, cada uno de estos, como motivo impulsador y generador del proyecto en sí.

\section{LA CIUDAD UNIVERSITARIA DE MADRID COMO LA VOLUNTAD POLITICA E IDEOLOGICA TRADUCIDA AL ESPACIO ARQITECTÓNICO.}

3-El proyecto arquitectónico y urbano como instrumento político y reflejo de la ideología.

Se tratará de analizar, mediante la mirada, la memoria y las formas del lugar, las diferentes muestras de construcciones y paisajes fruto de la génesis de confrontación de ideas espaciales y compositivas, de la confrontación de dos bandos en un conflicto bélico armado y de la confrontación de usos docentes diferentes al ámbito universitario. Las obras de diversos arquitectos construidas bajo un innovador y potente proyecto, tanto compositivo como formal; su posterior pérdida por un hecho ajeno y su posterior puesta en valor hasta la reconstrucción, hacen que los inmuebles y los lugares del conjunto escogidos para este trabajo, respondan al tipo de "edificios estratégicos" para poderlos así estudiar de forma comparada, con el fin de tener conocimiento de su realidad, independientemente de que

1 Cela, Camilo José. La colmena. Edaf, 2002. Pág. 204. 
resulten más emblemáticos unos que otros, o más o menos significativos dentro del ámbito de estudio. Sólo desde el conocimiento del conjunto, de su etapa generadora (1926-1956) se puede obtener una idea real de lo que fue el proyecto, proyecto que es ahora parte de la ciudad de Madrid. Para ello se han formulado las siguientes hipótesis divididas por temas o capítulos durante la investigación y desarrollo el trabajo:

1. LUGAR / Espacio-Tiempo: La innovadora obra, realizada por un grupo de arquitectos e ingenieros, dio lugar a un claro y unitario proyecto que le hizo ser continuado y desarrollado a pesar de las diferentes y contrarias teorías políticas o educativas de los sucesivos gobiernos de las épocas. Su valor e ideal intrínseco, persisten todavía en su trazado y en su arquitectura, a pesar de las modificaciones o agresiones que han influido en gran medida en la trasformación del lugar, después de la confrontación bélica en la capital, durante su período de reconstrucción e incluso posteriormente en una época más reciente.

2. FORMA / Génesis: Las nuevas necesidades y tendencias en la sociedad del momento inicial, hicieron que el nuevo trazado y proyecto no solo respondiera a unos condicionantes estéticos y funcionales sino a nuevas teorías de urbanismo y de educación en la enseñanza universitaria. Importadas la gran mayoría de Estados Unidos y Gran Bretaña, que fueron ejemplo para nuevas universidades posteriores del resto de Europa y de América Latina. Fue un proyecto pionero que trasladaba las ideas y tipologías extranjeras de la "forma de vivir en un campus" a la tipología universitaria docente de la vieja Europa.

3. FísICo/ Transformación: La experiencia de la confrontación en primera línea de batalla no le dio, al lugar, más que un valor añadido de "lugar físico ofensivo y fortificado". Se convirtió en una zona que sumaba las construcciones previamente educativas, con las construcciones estratégicas militares como puntos de baluartes y protección. Nuevos usos y valores constructivos. Una nueva serie de construcciones y trasformaciones que modificaron, más aún si cabe el proyecto arquitectónico, el terreno, dándole un nuevo uso, funcionalidad y "marca" o "huella desaparecida" al lugar.

4. CONCEPTO/Distorsión: Los lugares desaparecidos, los edificios reconstruidos y los espacios trasformados por nuevas necesidades o ideologías, son un último valor añadido al proceso del "proyecto generador" que configuró el primer recinto universitario moderno en la Europa del siglo pasado. Las decisiones e ideas formales previas, trasformaciones físicas, destrucciones y agresiones de diferente origen, variaron más tarde hacia la distorsión final del primer "campus" que configuraron su razón de ser y así su llegada a como lo conocemos en la contemporaneidad.

5.CONCLUSIONES/ Patrimonio En los lugares, espacios y construcciones iniciales de los 30 primeros años de la Ciudad Universitaria persisten valores, como estratos, que han permanecido escondidos, subyacentes, que la han hecho ser el sitio idóneo para ser considerada una de las mayores obras urbanísticas y arquitectónicas del siglo pasado. Sus procesos de conformación la han hecho convertirse en un sumatorio de valores únicos, topográficos, históricos, bélicos, proyectuales y arquitectónicos que le hacen un lugar único a nivel patrimonial. 



\section{INTRODUCCIÓN}

\section{PREAMBULO. INTENCIÓN Y OBJETIVOS}

El lugar es algo sorprendente, por eso nos seduce a cada uno de diferente manera. Es algo propio para cada uno. Un mismo lugar puede ser tan diferente, como las personas que acuden a él a mirarlo, contemplarlo o estudiarlo. Lo podemos ver de muchas formas: conocido o desconocido, cercano o lejano, pudiendo pertenecer o no a él, pudiendo sentirse atraído o intrigado. Pero es paradójico, que aunque creemos ser de un solo lugar, con el paso de la vida, algunos lugares nos hacen pertenecerles...

Era un desafío estudiar un lugar tan analizado y criticado. Pero era ese desafió, el aportar algo más, una pequeña visión diferente, otro acercamiento mas actual, lo que me capturó.

La Tesis no se perfila como una línea única y limpia, responde a las hipótesis planteadas sobre los posibles "procesos proyectuales subyacentes de la Ciudad Universitaria de Madrid" utilizando un método a través de trasformaciones sucesivas y continúas; apariciones y desapariciones, de intenciones, de trazas. Es un esbozo de la inquietante y continúa búsqueda de la esencia del lugar, de la arquitectura y de las relaciones entre los espacios que se han generado a través y por el proyecto. Un esbozo de un trazo nuevo, paralelo, quizás más amplio o abstracto, para obtener unas conclusiones de investigación que pudieran llenar los vacíos que existieran en referencia a una completa reinterpretación de este lugar y con una mayor relación con los pensamientos proyectuales de la actualidad. Una reinterpretación como valor añadido y como nuevo significado, desde una mirada más contemporánea.

Se propone un viaje que sumerja o lleve al lector a lugares, espacios interiores y exteriores de una época pasada, con la posibilidad de imaginar esa estructura subyacente de cada proceso proyectual que dio lugar a los diferentes estratos que conformaron La Ciudad Universitaria de Madrid. Gracias a toda la documentación encontrada, descubierta y a algunos libros que por "casualidad" (o por obra del destino) cayeron en mis manos se ha realizado esta tesis como un intento por atrapar nuevas relaciones entre las construcciones y los espacios, entre los conceptos formales, físicos, conceptuales y simbólicos. Una tesis como un camino donde el andar contemplando y mirando es mas satisfactorio que el llegar.

Es importante remarcar que no soy historiadora ni cartógrafa, y que las teorías filosóficas del conocimiento o pensamiento más actuales del siglo XX ayudan pero serían quizás, solo en algunos casos, prescindibles para la realización de una tesis de Arquitectura. El lugar, los conocimientos de nuestra disciplina y todos los estudios adquiridos durante la "carrera" y el doctorado, por medio del análisis y la reinterpretación podrían y deberían ser suficientes. Soy consciente que todavía me falta mucho por leer y estudiar, y que esto no es sino el primer escalón de una investigación que seguirá ampliándose y desarrollándose con el tiempo. He podido hilvanar y coser esta trabajo gracias a la confluencia de documentación, información y bibliografía de varias disciplinas, y que es el umbral de una teoría que ha comenzado. En todo caso, esta investigación que sólo pretende centrarse en una zona 
concreta y durante una época (1926-1956) determinada en un tiempo específico de La Ciudad Universitaria de Madrid, quedará abierta a futuros estudios del resto de edificios, lugares o construcciones similares en el mismo ámbito, o incluso de diferente época, con lo que se podría enriquecer considerablemente el análisis de todos ellos como un conjunto arquitectónico global que ha llegado hasta nuestros días.

Considero, que a pesar de ser la etapa de confrontación en La Ciudad Universitaria, una época prácticamente obviada y no analizada en la mayoría de libros de arquitectura y urbanismo, y sumando las dificultades que plantea abarcar un tema tan amplio, lejano y militarmente técnico y complejo, como son los tres años de enfrentamiento entre dos bandos hermanos, queda justificada la necesidad de abordar la cuestión, incluyendo dicha época, no como un paréntesis sino como un momento más dentro de los procesos secuenciales del proyecto arquitectónico, por la labor y la importancia estratégica que tomaron estos lugares en el desarrollo del proyecto posterior.

Es por todo esto y por ello, por lo que me planteo los siguientes objetivos:

- Demostrar, con el análisis de la documentación encontrada de diferentes épocas, como el paso del tiempo y las necesidades urbanas, sociales e intelectuales, convirtieron a "La Universitaria" en un mezcla heterogénea de valores, olvidando algunos iniciales pero sumando otros nuevos. Así se demuestra porque fue considerada en diferentes etapas, un proyecto moderno, necesario y articulado desde su creación.

- Diferenciar, además de su conformación meramente morfológica, los momentos temporales, históricos, políticos y creativos, tan diferentes que marcaron este lugar, en causa y efecto, en su proyecto de conformación arquitectónico como conjunto.

- Sentar la base de posibles caminos para el estudio de otros tipos de estratos subyacentes a los arquitectónicos o urbanísticos más visibles. Buscando y estudiando conceptos, enterrados o borrados, por ser considerados de otras disciplinas que no se relacionan con la arquitectura.

- Plantear, si cabe, la existencia de algún hilo argumental estilístico o compositivo, que permita explica y rastrear de donde procede, como se ha desarrollado y hacia donde se dirigen las soluciones adoptadas que se han realizado en este recinto único.

- Redibujar analíticamente la suma de procesos que ha dado lugar a este campus único en la primera mitad del siglo pasado, que todavía hoy sigue transformándose y desarrollándose.

Se mantendrá un análisis intencionado con el objetivo de encontrar significados propios a través de los procesos, siendo consciente de que en este camino se intenta dejar el sentido interpretativo subjetivo y sentimental, imponiendo el científico y metodológico, para que aspectos morfológicos intrínsecos nuevos salgan a la luz, llegando a una teoría coherente y demostrada con claras explicaciones en diferentes niveles o escalas.

Por tanto, las conclusiones que se obtengan en este trabajo de investigación se deben entender como tránsito, como un medio, hacia el conocimiento global de todos los tipos de edificaciones, construcciones y lugares que conforman lo que podríamos empezar a llamar 
"Los procesos de la Universitaria”. Un riquísimo ámbito tanto en el tiempo como en su extensión, tanto por su riqueza arquitectónica como proyectual de todas las épocas tanto pasadas como actuales.

\section{EL ARQUITECTO QUE ESTUDIA Y ANALIZA UN LUGAR}

El arquitecto mira y ve allí donde otros no ven.

El paisaje tan sólo existe a través de nuestra experiencia. Es un proceso que actúa sobre nosotros y sobre el que, a su vez, nosotros intervenimos. Es una idea y una imagen definida a través de un diálogo entre nosotros y el territorio. Todo paisaje es único; su carácter singular solamente puede ser comprendido a través de la experiencia, la interpretación y la representación ${ }^{1}$

\section{La experiencia}

Mi vinculación personal con el tema comienza, cuando La Ciudad Universitaria de Madrid empieza a ser testigo de mis años de estudiante. Mi primer proyecto como estudiante de Arquitectura se localizó en los Campos de Deporte de la Ciudad Universitaria de Madrid, junto a la Avenida Juan de Herrera. Un proyecto donde las gradas, la extensión de los campos, el viaducto y la piscina se perdían y vagaban libres en escala, proporción y orden, por las escasas capacidades gráficas y espaciales con las que disponía en aquel momento. Sin embargo, ese primer proyecto me hizo descubrir como los arquitectos debíamos acercarnos al lugar, descubriendo y analizando el espacio de una manera diferente a como lo hacen otras disciplinas. Ni mejor, ni peor, pero simplemente de manera diferente.

\section{La interpretación}

Según Javier Maderuelo, y su "Escuela de la mirada", los arquitectos a lo largo de la historia se han "autorreferenciado" y no se han relacionado con su entorno o su medio físico, una ceguera que llevó durante mucho tiempo a la planificación de ciudades inhóspitas o a construir lugares con falta de identidad. A diferencia de los arquitectos, los artistas y los arquitectos-paisajistas llegaron mucho antes a entender, observar y valorar los paisajes -los lugares-, pero los arquitectos supieron en un momento añadir este valor a su obra, muchos de ellos intrínseco en su manera de proyectar y elaborar sus creaciones, sin entenderlo como una cualidad adicional, sino como algo natural.

MIRADA MEMORIA FORMA [LUGAR]

INTENCIÓN ESPACIO-TIEMPO SIGNIFICADO

\footnotetext{
${ }^{1}$ Waterman, Tim y Wall, Ed (2013). "Un diálogo con el paisaje: proyecto, representación y proceso". Urban, NS05, Artículos y Notas de Investigación. Pág.37
} 
Bajo una mirada del proyecto y bajo la disciplina de los conocimientos en Arquitectura, este trabajo será un intento de sentar las bases para definir un instrumento de referencia para conseguir el entendimiento de una relación entre mirada, memoria, y el significado de las formas que conformarán un lugar de la ciudad de Madrid.

La mirada ___ posee una intención

La memoria__acota un espacio de tiempo

Las formas___ poseen significados

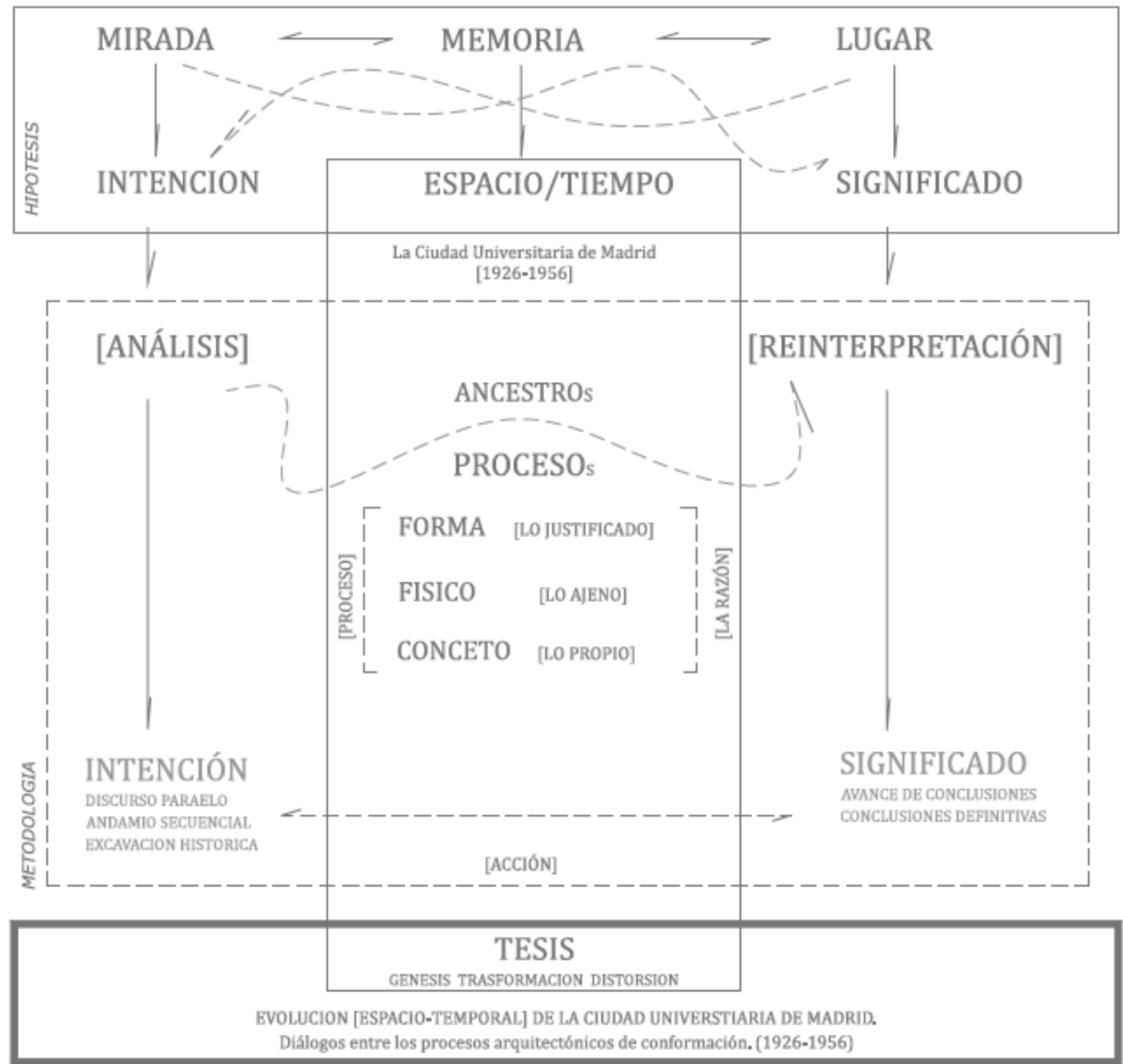




\section{La representación}

"La arquitectura no es simplemente sobre el espacio y la forma, sino también sobre el evento, acción, y lo que sucede en el espacio. Las transcripciones de Manhattan se diferencian de la mayoría de los dibujos de arquitectura en la medida en que no son ni proyectos reales ni meras fantasías." 2

De la misma manera que Bernard Tschumi en su proyecto experimental de "Manhattan Transcripts", realiza una lectura diferente de la arquitectura en la que el espacio, el movimiento y los eventos son independientes, estos, a su vez, están en una relación nueva de unos con otros. Una arquitectura con programa, con acciones y acontecimientos. De ese modo los componentes convencionales de la Arquitectura se descomponen y se reconstruyen a lo largo de diferentes ejes. Podemos utilizar esta forma de sintetizar y descomponer en las transcripciones, como una representación, que de sentido a una realidad proyectual arquitectónica, en nuestro caso estratificada y abstracta por capas.

Tschumi desarrolla un método de representación a través de las transcripciones de Manhattan que él describe como un "trabajo en progreso". A través de estos dibujos de arquitectura se puede entender las formas de articular las búsquedas que relacionan las interacciones entre el hombre, el espacio y la ocurrencia de eventos.
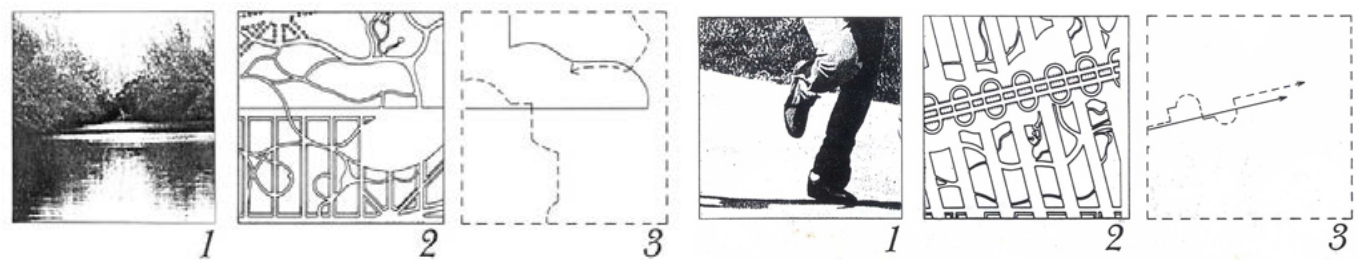

Figura 1. Manhattan Transcripts. Bernard Tschumi
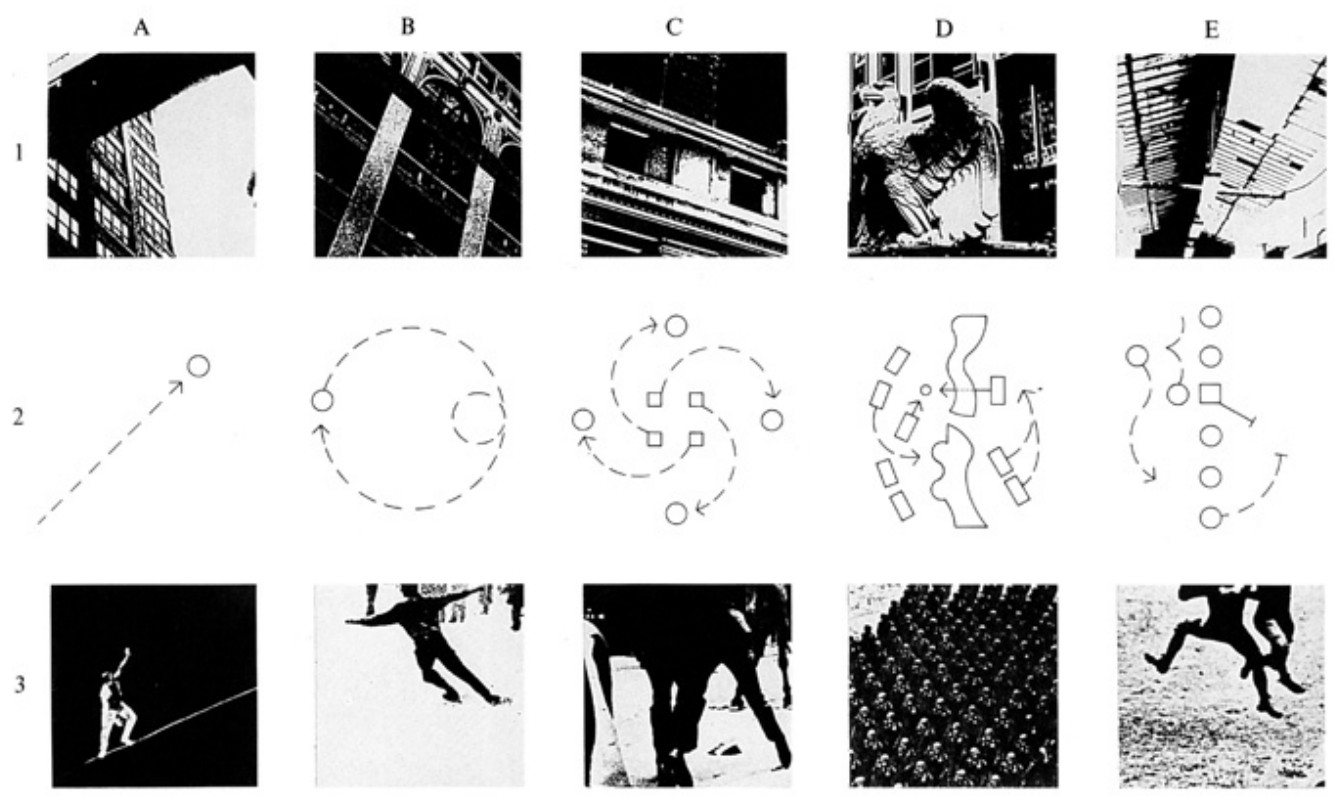

Figura 2. Manhattan Transcripts. MT4. Bernard Tschumi

2 Gardinetti. Marcelo. Las transcripciones de Manhattan. Bernard Tschumi /1976-1981 http://tecnne.com/?p=11024 


\section{MATERIAL Y MÉTODO}

\section{EL MÉTODO Y EL MATERIAL PARA EL DESARROLLO}

El método de BUSQUEDA,ANÁLISIS, PROCESOS Y REINTERPRETACIÓN de trabajo se puede resumir en las siguientes etapas de trabajo y estudio:

\section{1a_Fase: BÚSQUEDA. Recogida de información}

1. Revisión de trabajos previos sobre "La Ciudad Universitaria de Madrid. Búsqueda y análisis general del estado de la Arquitectura española en esos años tan convulsos de principios de siglo XX. Tendencias y vanguardias. EEUU y Europa.

2. Consulta y visualización de bibliografía y documentales de índole histórico, social y militar, sobre la Guerra Civil Española, en concreto, la Batalla de Madrid.

3. Consulta del material accesible de documentos, fotografías, memorias, planos, informes técnicos, presupuestos, proyectos etc. en archivos (públicos y militares), bibliotecas y hemerotecas.

4. Consulta de escritos, correspondencia, y entrevistas, que puedan dar información complementaria e inédita sobre el tema de estudio.

\section{2a_Fase: ANÁLISIS. Ordenación de la información}

5. Ordenación de la información obtenida dividiéndola o separándola por temáticas e identificando en que apartado va a ser estudiada. Cuatro capítulos de diferente duración que se caracteriza cada uno por un tipo de acción, trasformación y alteración sobre el terreno estudiado.

\section{3﹎__Fase: ESTUDIO DE PROCESOS. Comparación secuencial re-interpretativa.}

6. Tratamiento de datos obtenidos y bajo un método de trabajo de análisis científico, secuencial, confrontado y comparativo, de la diferente época y momentos que habían surgido durante el proyecto y realización de la Ciudad Universitaria. La intención ha sido obtener una metodología general de estudio extrapolable a otros lugares de similares características, subdivida en temáticas pero en orden cronológico secuencial.

\section{4﹎.Fase: CONCLUSIONES. Critica y posibles soluciones.}

7. Diálogos y correcciones sobre las ideas, teorías, concepciones y escritos realizados con expertos de diferentes materias y disciplinas sobre el lugar que es caso de estudio. Las conclusiones se llevarán a cabo como la síntesis de las ideas principales que se han obtenido en la fase de análisis comparado y su relación con las primeras hipótesis de la introducción. 
Para su mejor comprensión se ha dividido, la parte DESARROLLO (iii) de la tesis en cuatro capítulos autónomos pero ordenados, que constituye una estructura secuencial-temática del caso de estudio.

- ANCESTROs: El marco de reflexiones sobre el lugar y su marco espacio-temporal contextual. Antepasado o preexistencias.

- PROCESOs : La ideación, el dibujo, y la ejecución de sus proyectos a través de los capítulos de génesis, trasformación y la reconstrucción conceptual. Sometiendo a un lugar a un procedimiento de elaboración o de transformación, a operaciones lógicas y ordenadas cuyo fin es la obtención de resultados determinados.

La estructura de la parte de los procesos FORMA/ FÍSICO/ CONCEPTO se plantean de manera independiente como estratos, no como diferentes caras de una misma moneda, sino como un proceso que se suceden en la misma cara. Estos procesos, dan lugar al mismo resultado sumatorio o sedimentario, cuando se ven todos como una trasparecía desde arriba o como sumatorio al acoplarse.

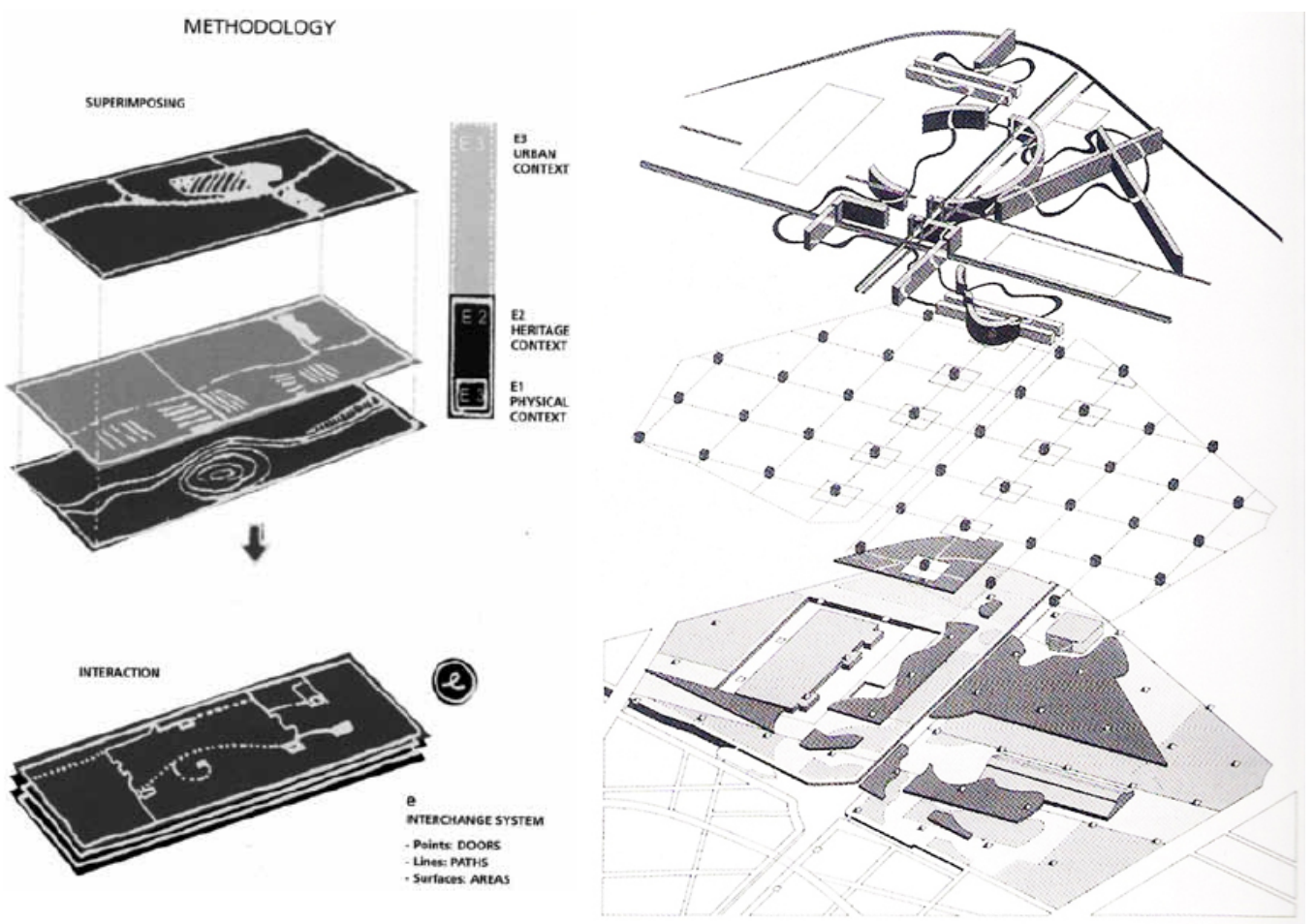

Figura 2. El paisaje cultural como espacio de identidad y realidad evolutiva. "El valor estructurante del patrimonio en la transformación del territorio”. Julián Galindo González. Joaquín Sabaté Bel. APUNTES Vol. 22, núm. 1 Pág. 20-33

Figura 3. Tschumi Architects. Descomposición por capas del Proyecto de Ordenación de La Villette . La descomposición de un plano de ordenación por capas temáticas y el reconocimiento de cada una de ellas con independencia de las demás y del conjunto se convierte en una verificación de la calidad del diseño. Una mala solución no resiste el análisis fragmentado de sus componentes. Forma y Ciudad. En los limites de la Arquitectura y el Urbanismo. Pág. 50 


\section{LA CIUDAD UNIVERSITARIA DE MADRID COMO ÁMBITO DE ESTUDIO. [ESPACIO]}

La Ciudad Universitaria o también llamada Campus de la Moncloa es una pequeña ciudad de trama independiente, anexa y articulada a su "hermana mayor", Madrid. Su diseño original novedosos de principios del siglo XX, se organizó bajo unas tramas, zonificaciones y ejes donde sus edificios, recién terminados, se convirtieron sin casi utilizarse, en baluartes y fortificaciones de un hecho bélico sin igual en nuestro país, siendo los testigos de restos y ruina que quedaron en el lugar. Se reconstruyeron de nuevo tras la contienda para volver a tomar su función original, pero el hecho de ser testigo en "primera fila" del hecho bélico mas relevante de España, la hizo tomar de nuevo parte de su significado y valores originales y ser marcada por otros nuevos que se han ido ampliando y desarrollando a través del tiempo, pero siempre con el carácter de perdurabilidad y continuidad impenetrable.

Siendo "La Universitaria" un lugar más entre otros a los que acompaña la Historia de la capital, se ha realizado esta investigación y análisis, con una nueva mirada y enfoque hasta los ahora realizados; en esta área que fue inicialmente un nuevo proyecto docente para una ciudad. Todo un proceso con cambios sucesivos u obligados, de valores y diseños tanto en lo social, político como en lo arquitectónico o paisajístico. Del mismo modo, este proyecto se acerca a su aniversario centenario, aunque los últimos años de desarrollo, modificación y colmatación la haya desestructurado y distorsionado, alejándola del inicial e idílico proyecto del recinto universitario.

La consideración y la puesta en valor de el PROCESO INICIAL CONFIGURADOR arquitectónico de los treinta primeros años, que se perdió en los años del desarrollismo y continuó su perdida hasta la actualidad, es el motivo y la clave por el qué se ha escogido este período para esta investigación. Será una manera de recordar y reclamar un tratamiento del lugar acorde con el valor histórico, proyectual y urbano que se merece.

Se llegarán a los cien años de la Ciudad Universitaria y todos sus ocupantes, organismos y administraciones lo celebrarán pero sin haber realizado ni una de las mejoras que tanto tiempo se llevan pidiendo desde algunos sectores de la sociedad. Un ámbito que frente al olvido que ha sufrido tiene que ser reformado y actualizado como una universidad contemporánea y ampliable, acomodándose a los cambios de las sociedad y del sistema docente o universitario, como se pensó y se pretendió realizar desde su proyecto inicial. La Arquitectura como elemento de construcciones y espacios que puede seguir absorbiendo cambios y mejoras. 


\section{LA VISIÓN PANORÁMICA DEL PASADO DESDE EL PRESENTE [TIEMPO]}

Una visión del pasado desde el presente, entendiéndola como sumatoria de estratificaciones o de manera inversa, pero también pudiéndose haber estudiado como una visión del presente, pero apartando y separando capas o estratos hasta llegar a su origen: "La superficie del terreno sobre el que se graba la memoria de sus trasformaciones, se convierte en un mapa y en la crónica del lugar. En esta presencia intensificada del lugar hay una materialidad sensual que es descrita por Descombes como una ‘acumulación sedimentaria de huellas'. La estética de la revelación mantiene una tensión entre el pasado y el presente, entre lo que esta ahí y lo que ya no está" 3.

Un trabajo previo de aproximación al LUGAR [LO CONTEXTUAL] posibilitará la "construcción" de las preexistencias que había en esa parte de la ciudad y la representación del escenario de actuación como elemento integrante previo (Ancestro) al propio proyecto, interactuando con el PROCESO del proyecto arquitectónico a lo largo de los capítulos: FORMAL [LO JUSTIFICADO], FÍSICO [LO AJENO], CONCEPTUAL [LO PROPIO]. Se entenderá como un camino continuo de mecanismos interconectados entre el lugar y la variación formal, física y conceptual del conjunto arquitectónico, con el fin de conseguir significados nuevos de reinterpretación, bajo una visión más actual y con la lejanía del tiempo que ha trascurrido en un "lugar", ya antes analizado y estudiado.

A partir de la lectura de un territorio dado, según las premisas definidas por el "suburbanismo"4 y del estudio de la relación entre un objeto arquitectónico, su entorno y su evolución, se pretende dotar a La Ciudad Universitaria de Madrid, un lugar anexo a otra ciudad que ha sido objeto de un desarrollo continuo y secuencial en el tiempo (bajo diferentes momentos políticos y sociales); de una metodología de aproximación al lugar y a su concepción arquitectónica, que nos permita "construir" su descripción y representación como elemento integrante del proceso proyectual.

“El tiempo no es lo que ya pasó ni lo que aún permanece, es nuestro emplazamiento en él, que contiene el pasado y en el presente está pre-configurado el futuro" ${ }^{5}$. Reflexiones sobre el tiempo en el espacio de la historia nos recuerdan el concepto benjamino de ahora de acuerdo con Gurménez. Ya no hay representación de la realidad, sino reconstrucciones de la misma en otro tiempo, que se actualiza a la vez en el tiempo individual de la mirada de los diferentes espectadores.Es en conclusión, una reinterpretación mas actual, abstracta y complementaria (a modo de reinterpretaciones formal, física y conceptual), ampliando los estudios realizado hace más de tres décadas en el mismo lugar. Una perspectiva del proyecto arquitectónico de conjunto, enfocada al estudio del suelo como portador de memoria, en su representación física y cartográfica, así como la relación de éste con el hombre, con el proyecto arquitectónico realizado y de la memoria que éste guarda.

\footnotetext{
3 Marot, Sebastián. Suburbanismo y el arte de la memoria. Gustavo Gili. 2006. Pág.- 126

${ }^{4}$ Marot, Sebastián., Sub-urbanismo y el arte de la memoria. Gustavo Gili. 2006

5 Ábalos, Iñaki. Campos de batalla:(Laboratorio de técnicas y paisajes contemporáneos, ETSAM, 20022003). Actar; Col-legi d'Arquitectes de Catalunya, 2005. Pág. 10
} 


\section{JUSTIFICACIÓN DE LA ELABORACIÓN DEL ESTUDIO EN EL CONTEXTO ACTUAL.}

"Quienes no pueden recordar el pasado están condenados a repetirlo"6

En España en los últimos años la llamada "Recuperación de la memoria" o "Memoria Histórica" ha resultado una forma inestable y sentimental de volver a hechos pasados, pero casi nunca tratando el punto de vista patrimonial, arquitectónico o paisajístico. La mayor parte de los estudios, escritos e investigaciones se han realizado como investigaciones locales o de profundos aficionados, nunca desde las instituciones públicas o universidades. También son muchas las tesis que abordan este período de la Historia de España desde diferentes temáticas: históricas, artísticas, políticas, de medios visuales o periodísticos, pero muy pocas son ya las que toman el tema o los años de la Guerra Civil como período de estudio en una tesis de Arquitectura. Y mucho menos de sus construcciones, que quedan relegadas a construcciones e infraestructuras de estudio civil, ingeniero o militar. ¿Es posible encontrar un proyecto analizable de arquitectura, de urbanismo, o de espacios en las construcciones bélicas?

Durante los años previos de investigación y acercamiento a "mi tema y ámbito de estudio" sobre el que versa esta tesis, fue fundamental la colaboración en el Proyecto de Investigación, junto con la Universidad Complutense de Madrid y La Casa de Velázquez, de la planificación, organización y ejecución del Congreso y Exposición "Paisajes de una guerra". Dicho congreso, realizado en Madrid durante los días 7, 8 y 9 de mayo de 2015, me permitió realizar una comparación directa de mi tema de estudio con otras disciplinas, más históricas o artísticas. Muchas de las ponencias en este congreso se dedicaron a temáticas, estudios e investigaciones anteriores, habiéndome servido muchas de ellas como base o punto de comienzo en este trabajo.

La colaboración en el grupo que se encargó de recuperar y montar la maqueta de 5,30m x $5,10 \mathrm{~m}$, realizada para la reconstrucción del recinto universitario en 1943, que se encontraba desmontada y almacenada, también me permitió un acercamiento diferente a mi lugar de estudio. Un trabajo físico y mental de saber hacer y organizar un verdadero puzzle del lugar, de la misma manera que se organiza el puzzle de los capítulos de esta tesis en mi cabeza.

Es imprescindible hacer referencia a la gran conocedora del proyecto de la Ciudad Universitaria de Madrid en todo su conjunto, Pilar Chías Navarro. Su tesis "La Ciudad Universitaria de Madrid: planeamiento y realización" realizada y defendida en la Escuela Técnica Superior de Madrid (ETSAM) en 1983 es el estudio más completo, global, cronológico y contrastado que se ha hecho hasta el momento sobre La Ciudad Universitaria de Madrid como proyecto arquitectónico y urbanístico, sin olvidar la gran cantidad de documentación histórica y legal que utiliza como apoyo en su investigación.

Existen otras tesis más enfocadas al ámbito del recinto y la evolución de los espacios universitarios o docentes como institución y de manera mas relacionado con lo urbano y la

${ }^{6}$ George Santayana, filosofo hispano-estadounidense, escritor de La vida de la Razón. 
ciudad. Habría que citar tesis específicas y otras más generalistas de algunos de los arquitectos que formaron parte del grupo de arquitectos escogido para formar parte del grupo que proyectó La Ciudad Universitaria de Madrid. Tesis sobre Modesto López Otero, la arquitectura de Sánchez Arcas, Luis Lacasa o Agustín Aguirre, así como tesis completas o de obras del ingeniero Eduardo Torroja Miret que tan relacionado estuvo con el calculo de estructuras e infraestructuras en la universidad y cuyas obra de hormigón han sido objeto de numerosos estudios y artículos o tesis, tanto a nivel independiente o de manera a modo de génesis global de un obra completa de autor.

Sin embargo, era recurrente y algo sorprendente, que en la mayoría de los escritos o publicaciones sobre La Ciudad Universitaria de Madrid, la franja de los tres años (19361939) durante el periodo bélico de confrontación, solo se especificara que fue "primer frente de batalla" o que "sufrió numerosos destrozos" o "quedó prácticamente en ruinas". Fotos, artículos en hemerotecas y algunos estudios de otras disciplinas hacen mención a esta parte, pero sin ninguna referencia a la arquitectura, al urbanismo o al paisaje semiurbano que se originó en aquella zona por los hechos que allí acaecieron. Es por ello lógico, que este período fuera tanto en el proceso de investigación, análisis y desarrollo el más desconocido y del que más información o conocimientos tendrían que surgir. Además que la gestión patrimonial de los lugares ligados a un proyecto arquitectónico novedoso y a un hecho histórico, debería valorarse y estudiarse para que las memorias colectivas e individuales tomen su importancia en la construcción de identidades comunitarias y personales futuras.

\section{FUENTES PRIMARIAS Y SECUNDARIAS.}

Las teorías y explicaciones desarrolladas en este trabajo de tesis doctoral se sustentan básicamente en el material documental consultados en fuentes de información escrita, bibliotecas y en los archivos, así como en un diálogo con la opinión de personas expertas en este campo y que ha desarrollado su trabajo de investigación sobre este tema desde diferentes perspectivas que se pueden entrelazar bajo el lugar común que es "La Ciudad Universitaria de Madrid". Tanto en el antes como en el después del momento de la Guerra Civil, así como en disciplinas diferentes como son la histórica, paisajista o militar.

\section{_Fuentes primarias}

Este trabajo de investigación se ha servido fundamentalmente de documentación inédita y otra ya encontrada o consultada, pero a veces no publicada ni digitalizada, procedente de diversos archivos, bibliotecas o trabajos previos, además de la toma de datos in situ del lugar. Se ha encontrado gran cantidad de artículos, noticias, planos, fotos y mapas, tanto de índole militar como geográfico, catastral, urbano o de población, que hacen referencia y aportan datos y detalles de cómo fue modificándose o alterándose en cada momento, el ámbito de estudio.

El trabajo de selección se ha basado en las fuentes primarias de planos, manuscritos y documentación, que pude consultar y manipular de la fuente original, la mayoría encontrados en depósitos de archivos civiles y militares. 
Los escritos biográficos de mi abuelo en su diario sobre sus vivencias en el recinto universitario durante la Guerra Civil Española, han servido de manera fundamental en la investigación como fuente original inédita. La posesión de estas memorias, con la descripción de algunos hechos que contaba como soldado de la Guardia de Asalto Republicana, durante los tres años de asedio de Madrid, me facilitaron de manera paralela acércame a ese paisaje pasado que intentaba hacer propio. Una documentación inédita y de gran valor familiar que se adjunta en el anexo de este trabajo. También gracias a la memoria de conversaciones pasadas y recuerdos familiares, he conocido algunas historias o anécdotas relacionando a mi familia con la zona que analizo y personajes de aquella época. Pero lo fundamental para este trabajo, es la utilización de la documentación que dejó mi abuelo sobre lo que vio y vivió en ese lugar que he estudiado, e imaginado, para explicar de manera secuencial una posible teoría sobre la trasformación proyectual de su paisaje.

De igual modo, la conversación-entrevista con un antiguo soldado nacional que había vivido durante cinco meses en la Universidad durante los mismo años que combatió mi abuelo, ha sumado nuevos conocimientos y verificaciones a lo que estaba estudiando e investigando, con la grata consecuencia de poder contrastar mis estudios, planos y análisis con la vivencia y experiencia vital de una persona que allí había combatido. Dos visiones de una misma zona desde bandos diferentes y contrarios.

\section{_Fuentes secundarias.}

De igual manera se han utilizado libros, tesis y artículos que hacen referencia a otras fuentes primarias, en el caso de utilización de esta materia siempre se ha intentando hacer referencia a la fuente original.

Información menos relevante para el tema de esta tesis, pero de gran importancia se ha utilizado y conseguido durante la investigación, lo que permitirá posibles tesis futuras, continuando el estudio de la zona y de los que se hace referencia en alguno de los epílogos de varios capítulos. Son así los planos originales del proyecto de la Casa Velázquez de 1922 de Daniel Zabala y los planos de reconstrucción de 1954-1958 que facilitó la institución francesa para su digitalización. Así como la localización en el AGA (Archivo General de la Administración en Alcalá de Henares) del proyecto original de La Escuela de Agrónomos de Gato Soldevila inaugurado en 1924 y del proyecto original de la Fundación del Amo, desaparecidas ambas construcciones durante la guerra y reconstruida solo la primera bajo un nuevo proyecto, muy lejano del original a modo de palacete del que solo se conserva ya sus planos.

Esta tesis, y de ello viene su subtítulo, intenta ser como un diálogo, entre el antes y el después, lo que fue La Ciudad Universitaria de Madrid (CUM) y en lo que se ha convertido, sobre el lugar que era y ahora es desde cuatro puntos de vista interconectados y ordenados por los diferentes hechos y destrucciones que generaron el lugar. Un trabajo-guía, entre el pasado y el presente, entre el diseño original y el diseño reconstruido. Un diálogo entre los dos frentes que allí combatieron, entre las edificaciones que quedaron enfrentadas "mirándose" y lo que ha llegado de todos estos proyectos, etapas y paisajes que se han ido modificando y desarrollando con el tiempo hasta la contemporaneidad. 
El DIÁLOGO entendido como:

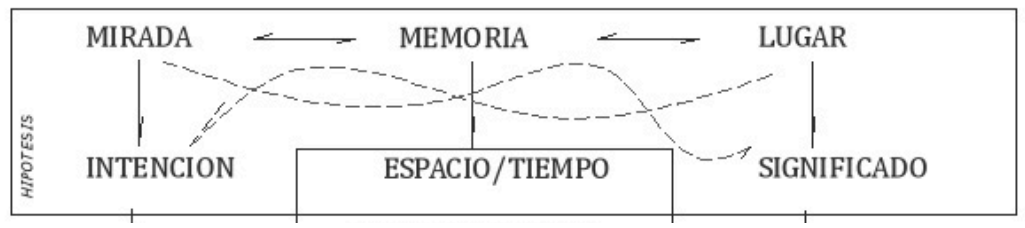

\section{[MIRADA]}

- Lectura temática de un lugar en momentos diferentes y mirada arquitectónica.

- La mirada como análisis con la intención de una nueva reinterpretación que actualice un estudio pasado pero desde la contemporaneidad

- Mecanismo para analizar un proceso donde la arquitectura y el lugar forman el proceso generador de 30 años, en contraposición del desarrollismo que rompió el concepto de unidad y de proyecto posterior.

\section{[INTENCIÓN]}

- Búsqueda de reinterpretaciones a modo de estratificaciones o procesos independiente como un elemento sumatorio en el proceso proyectual.

- Encontrar la relación entre los distinto procesos de conformación del recinto universitario, con base al momento histórico, proyectual, formal, físico y conceptual.

- La intención creativa no es la mirada, ni la memoria, es la "materia" de la memoria.

\section{[MEMORIA]}

- Conclusión o critica con reflexiones sobre el pasado y sus consecuencia en el presente.

- Memoria y herencia del lugar como huella. Visible, borrada o desconocida.

- Una comunicación del lugar o de elementos con sus ancestros.

[ESPACIO/TIEMPO]

- Conversación de como era, como es y lo que podía haber sido.

- Visión de lo contemporáneo estudiando el pasado desde el presente.

- $\quad$ Espacios y arquitectura que se han modificado, desaparecido y otros ha permanecido.

\section{[LUGAR]}

- Estudio comparativo como un trabajo de "acupuntura" temática.

- Capas o estratos de acontecimientos superpuestos y secuenciales.

- La actualidad y el pasado, en el mismo lugar.

[SIGNIFICAD0]

- La Nemotecnia y la Memoria como estimulo de creación.

- Antecedentes que proponen nuevas imágenes y significados

- Conversaciones sobre la visión futura y crítica de la actualidad. 
A mi abuelo, porque él lo pudo ver con sus propios ojos... 



\section{AGRADECIMIENTOS}

Mis más sinceros agradecimientos...

A La Ciudad Universitaria de Madrid ¿Cómo se puede "mirar” tanto un lugar?.

A mis directores de tesis, Joaquín Ibáñez Montoya y Pablo Campos Calvo-Sotelo, por contagiarme su entusiasmo por investigar, descubrir y aprender cada día, por compartir su sabiduría y ayudarme en esta odisea en que a veces se convierte la tesis.

A los bibliotecarios de la ETSAM y a los encargados de todos los Archivos Militares y Públicos, que me ayudaron a bucear en documentos, legajos y expedientes. Menudo mundo queda por descubrir todavía...

A todos los autores de la bibliografía por sus brillantes ideas y reflexiones que han contribuido a poder llevar esta tesis adelante. Cuanto me quedar por leer...

A todos aquellos que siguen indagando e investigando por este lugar, para que no desistan en la búsqueda. En especial a Leyre, Jara y José Luis, por tener tanta ilusión.

A mi maestra del colegio Concha, por animarme a estudiar Arquitectura. Allí donde estés, te recuerdo. A mi profesor de la Escuela José Manuel Sanz, para que siga escribiendo y enseñando tan fácil.

A Juan Antonio González-Cárceles y a su maravilloso legado, una pena no haber coincidido más. A mis informáticos Manuel y Jorge, que me han tranquilizado y salvado en momentos claves.

A Ángel Llorente y Pilar Pérez, por sus correcciones, conversaciones y consejos.

A Fernando Calvo González-Regueral, por su preciosa dedicatoria, sus explicaciones y su magnífico libro.

A los Antonios, por su interés y ánimos. Al que sabe tanto y me ha explicando cada batalla sobre el terreno, al que me organiza partidos y al que me animó tanto las noches de los lunes voluntarios.

A ese gran lugar que es Cedia, en especial a Paloma, no hay palabras suficientes para todos ellos.

A mis amigos de la escuela, Irene, Jon, Luis, Sonia, Carmen y en especial a Elena, por cubrirme, cuidarme y soportarme tanto...

A mis amigas Madrileñas que ninguna es de aquí...pero todas somos una.

A Pili, Inés, Marta, Ibone y Jelen, que además de amigas, son animadoras y psicólogas en prácticas.

A mi amiga Eva, por presentarme a su abuelo, animarme sin descanso y sus inmejorables consejos...

A Doroteo, por ilusionarme con sus recuerdos, su historia y sus vivencias.

A mis amigos y hermanos de SSCC, por lo que hemos compartido y lo que nos queda.

A mis amigos de tantos lugares: los corredores, los de los partidos, los que deje al otro lado del océano, las markelianas, los amigos de amigos, a los superhéroes...

A Conchita, por su apoyo entusiasta y aguantar mis desahogos telefónicos interminables.

A mi tía-madrina Maㅡ Carmen, ejemplo de mujer fuerte, luchadora y buena.

A mis queridas amigas, Teresa, Eva, Ana y María, porque siempre estáis cuando os necesito.

A mis compañeros y ahora amigos, Gonzalo y Esther, por todo lo pasado en la "sala de investigadores".

A mis abuelos, que están en "otro lugar" pero que siguen formado parte de mí en "este".

A mi primo Rafa, que sigue cuidándome y seguro leerá esta tesis.

A toda mi familia, tíos, primos, sobrinos, a todos los que forman "La Gran Familia"...

A mi hermana, que lo es todo y más.

A mis padres.

A todos, muchas, muchísimas gracias por estar siempre a mi lado. Ahora me toca volver... 



\section{DESARROLLO}

Organización del documento en capítulos

$\begin{array}{ll}\text { cap1- LUGAR _ } & \text { Contexto/[LO CONTEXTUAL] / Espacio-Tiempo } \\ \text { cap2- FORMA_ } & \text { Temático/ [LO JUSTIFICAD0] / Génesis } \\ \text { cap3- FÍSICO _ } & \text { Temático/ [LO AJENO] / Transformación } \\ \text { cap4- CONCEPTO _ } & \text { Temático/ [LO PROPIO] /Distorsión } \\ \text { ANEXOS } & \text { Contexto/ Marco Complementario }\end{array}$
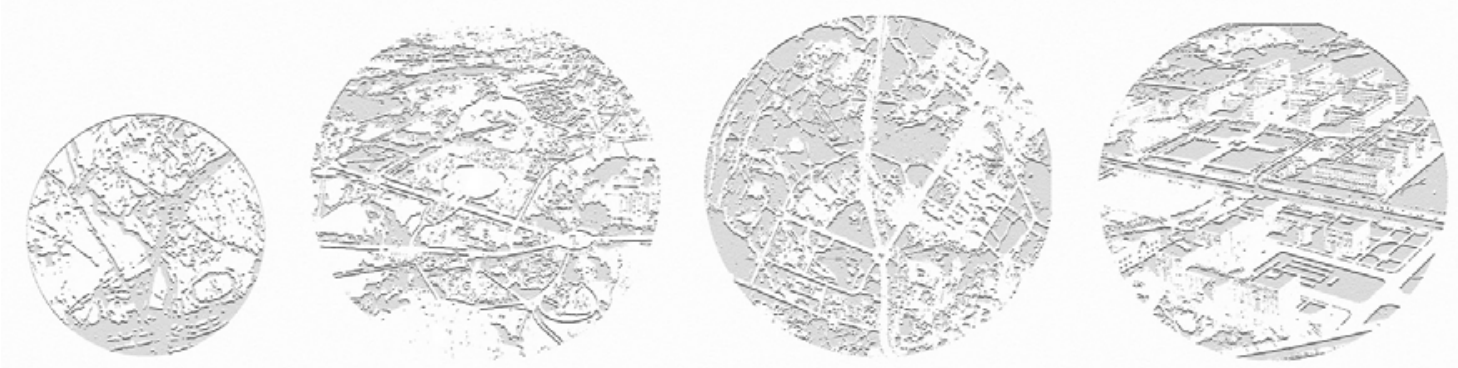


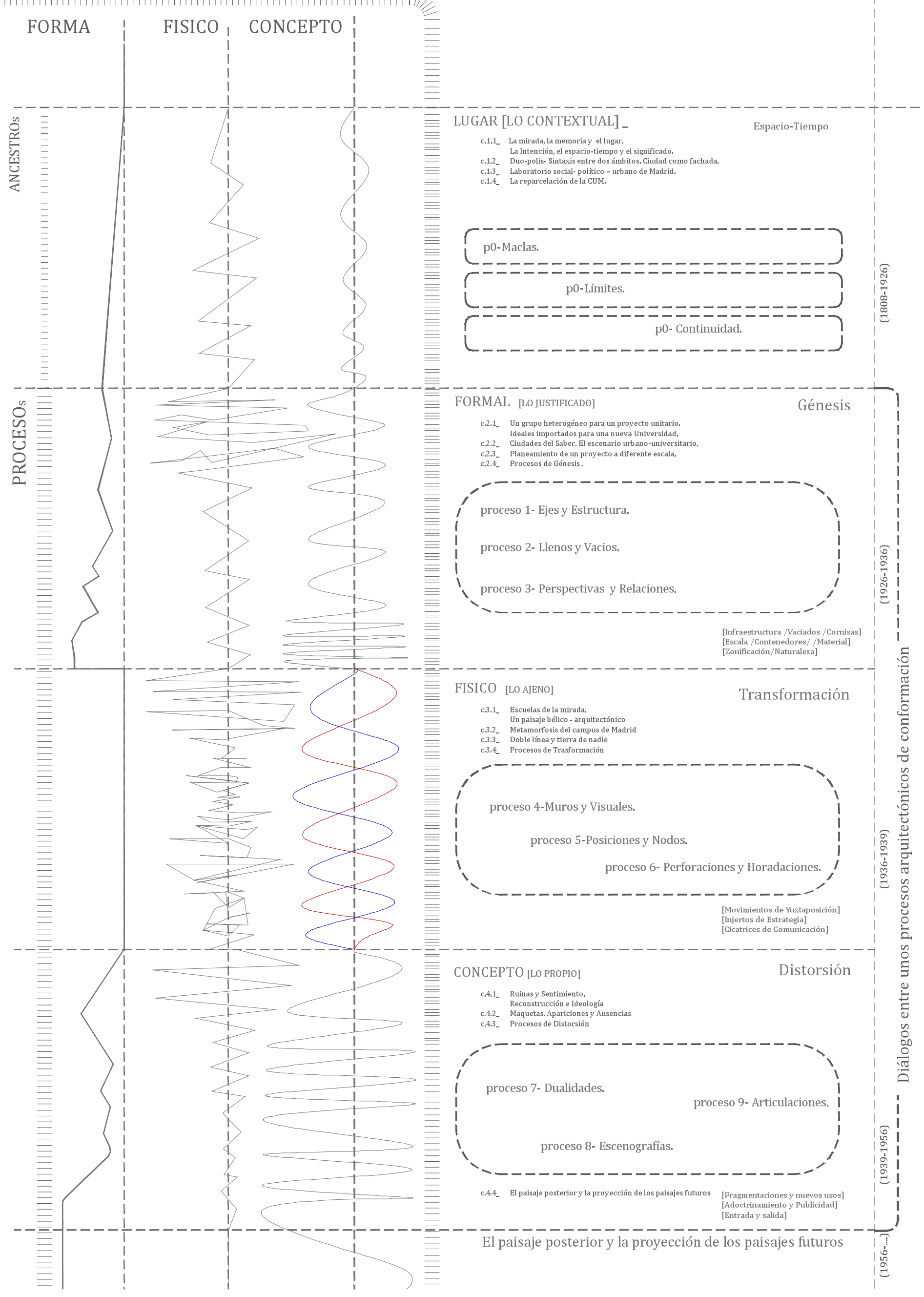


ANCESTROs $^{2} \ominus$
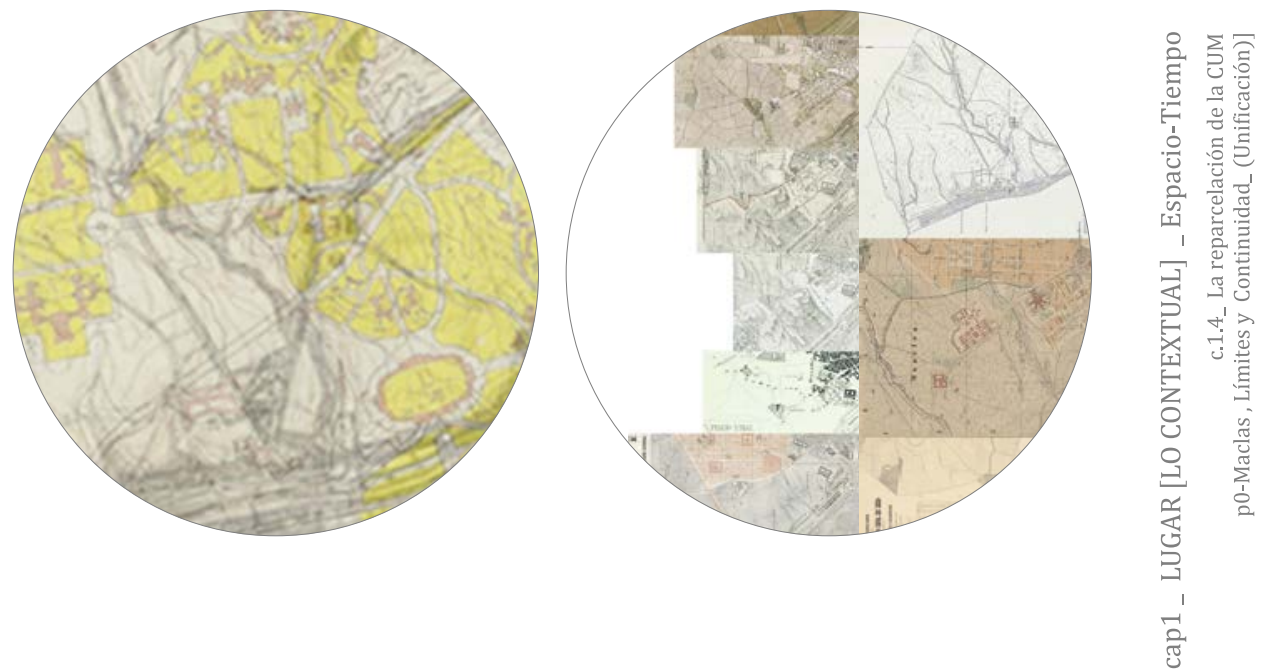
El valor histórico es evidentemente el más amplio y puede, por tanto, ser analizado en primer lugar. Llamamos histórico a todo lo que ha existido alguna vez y ya no existe ${ }^{1}$.

${ }^{1}$ Riegl, Aloïs. El culto moderno de los monumentos. A. Machado Libros, Madrid,1987 p.24 
CAP1 _ LUGAR [LO CONTEXTUAL] _ ESPACIO/TIEMPO

El espacio y el tiempo son dos términos íntimamente vinculados. El espacio es uno de los episodios del tiempo y esta situado en él. Acumular espacio no es lo mismo que acumular tiempo. El espacio es un hecho o suceso del tiempo, por tanto, en el estudio o análisis de los procesos que dan lugar a un lugar (espacio), es imposible sin considera a la vez la historia (tiempo), sin estudiar las trasformaciones y el movimiento (los procesos)..$^{2}$

Estos procesos son los generadores de una idea, de un proyecto...

"No fueron ecos que se hayan apagado los de aquella batallas. Muchos años han pasado y continúa el troteo"

2 Sáez, Horacio Capel. Dibujar el mundo: Borges, la ciudad y la geografía del siglo XXI. Ediciones del Serbal, 2001.p.43-44 


\section{C.1.1_ LA MIRADA, LA MEMORIA Y EL LUGAR \\ LA INTENCIÓN, EL ESPACIO-TIEMPO Y EL SIGNIFICADO}

Las formas, la memoria y la mirada están relacionadas. En una disciplina como la arquitectónica o la paisajística, la mirada posee una intención, la memoria acota un espacio de tiempo determinado, y las formas poseen significados que hay que analizar y descubrir. ¡Hay que aprender, hay que reinterpretar!

mirada___ memoria___ forma
intención___espacio- tiempo___ significado

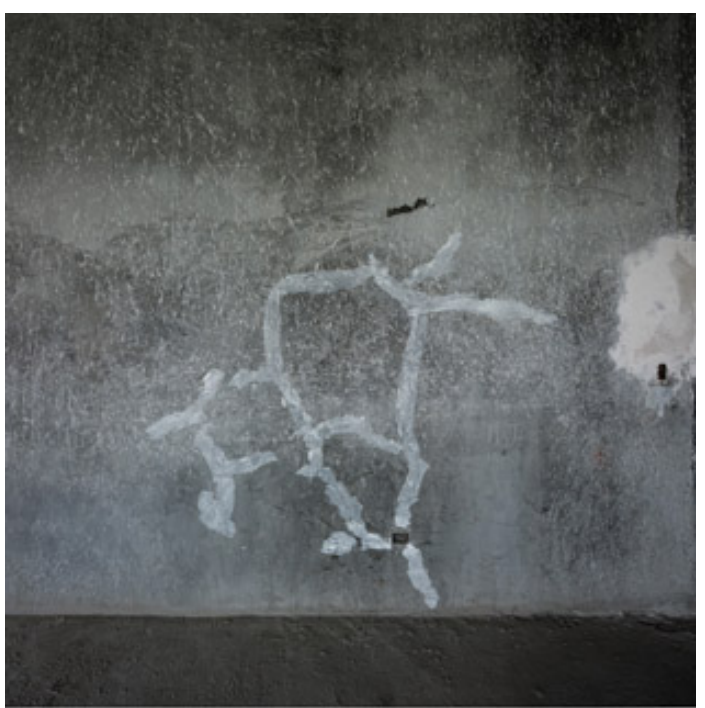

"La memoria de lo imaginad" Fernando Alda Undefined. Epifanía en Gris 2014

Es necesario establecer un puente entre la descripción literaria y plástica y el análisis científico y filosófico, mostrando que el paisaje no es una entidad cerrada sobre sí misma sino que ofrece muchas caras como tema de estudio ${ }^{3}$

La interacción entre estas parejas o tríos de palabras en nuestro estudio dan como desenlace unos conceptos y terminología para entender el paisaje [lugar] dotándolo de un nuevo significado, como una arquitectura o artificio de procesos que revelaban aspectos inadvertidos. Esta conexión entre disciplinas, campos y categorías que habían estado aislados, se unen por medio de un método ordenado encontrando la producción y resultando en una reinterpretación inédita (de un lugar ya estudiado) con nuevos significados espaciales, proyectuales o arquitectónicos.

${ }^{3}$ Maderuelo, Javier. “Aquello que llamamos paisaje”. Visions, Diciembre 2003, núm. 2 p. 24. 


\section{_La mirada posee una intención}

Las diferentes maneras de ver un lugar [paisaje], de describirlo o representarlo, supone que tras él hay un pensamiento; establece por tanto una relación directa entre el objeto que se admira y el sujeto que lo observa, a través de "la mirada" que es intencionada. Vemos solo aquello que podemos reconocer y pensamos, según aprendemos a ver la diversidad que nos rodea. De este tipo de mirada que reconoce y aprende surge una visión intencionada del objeto, una emoción ante lo que es un panorama o una visión determinada.

Los hombres siempre se han emocionado ante los espacios naturales, y así lo reflejan en la literatura y en la pintura de la antigüedad, pero a su vez también hay muchos sitios valorados que emocionan tras la actuación trasformadora humana que existe en un lugar [paisaje]; el orden y la ubicación de las construcciones o de los edificios en relación a su entorno.

El paisaje se encuentra en el interior de cada persona, que mira, que contempla y que interpreta con toda su propia cultura y toda su sensibilidad, por eso se dice que hay tantos paisajes como personas los interpreta. ${ }^{4}$

A parte de estos lugares, naturales o urbanos, hay alguno lugares que perteneciendo a un híbrido de los dos, están cargados de significado, de interpretación; quizá con menor capacidad de belleza estética, pero si con una relación más profunda e íntima con el entorno, con un momento histórico o con un hecho concreto que genera que sean otras premisas diferentes las causas para ser admirados e interpretados.

El paisaje no está en la mirada sobre los objetos, está en la realidad de las cosas, es decir en la relación que establecemos con nuestro entorno... ${ }^{5}$

El paisaje, aunque esté en la realidad de las cosas, no puede ser reducido a la mera mercancía o a lo existente, ya que no es un ente objetual, sino que se contempla en un medio o entorno que lo rodea y que desde luego, no le es ajeno. Ese sujeto que percibe y siente, en cuanto persona inteligente, es capaz, además de experimentar placer, de elaborar juicios y relaciones estéticas, formales, físicas y conceptuales.

Ese proceso de percibir, sentir y valorar (o apreciar) se aproxima al pensamiento, pero como indica Agustín Berque 6 , "para pensar se necesitan las palabras"7. Ese

\footnotetext{
${ }^{4}$ Rivera Blanco, Javier. Arquitectura: paisaje y patrimonio en la Comunidad de Madrid:[exposición]. Servicio de Publicaciones de la Universidad de Alcalá, 2011. p.123

${ }^{5}$ Berque, Agustín. El pensamiento paisajero. Ed. Javier Maderuelo. Biblioteca Nueva, 2009. p.59
} 
proceso de argumentar sobre lo que se ve, de generar poética y una iconografía sobre la mirada proyectada en el territorio se inició en nuestra cultura occidental, durante el Renacimiento, alcanzando en los últimos lustros altas cotas de producción intelectual que contrasta paradójicamente con la intensidad y rapidez con las que la humanidad está destruyendo el paisaje heredado... ${ }^{8}$

Por lo tanto, la disposición durante este trabajo, será la intención y la necesidad de "Aprender a mirar" con la actitud de ser arquitecto pero con la intención de identificar y distinguir las diferencias de un lugar que tuvo un gran componente de riqueza histórica, proyecto arquitectónico innovador y, a la vez, como un proceso trasformador, de un lugar incomparable a nivel de riqueza natural y paisajista de la capital. De esta manera, se comprenderá y se reinterpretará el paisaje como una suma, como un resumen de todo lo acumulado desde el punto de vista geográfico, topográfico, histórico, compositivo, proyectual, arquitectónico, táctico e incluso eventualmente estratégico. Con una visión analítica, se establece una metodología de estudio de análisis del lugar [paisaje] a través de capas, de estratos sucesivos.

Para el estudio es necesario utilizar tres niveles o escalas en cada uno de los procesos temporales y espaciales:

1- Escala territorial. Tomando el lugar y su paisaje como una unidad en sí misma que se ha modificado y trasformado sucesivamente en función y de acuerdo a los de diferentes proyectos arquitectónicos y urbanísticos, referenciados a sus momentos históricos circunstanciales.

2- Escala espacial compositiva. Según la mirada espacial o formal que se tenga, a la que se le suma la mirada temporal política o conceptual; ambas miradas fueron los verdaderos trasformadores del lugar bajo sus acciones e intenciones arquitectónicas o de simbología.

3- Escala arquitectónica. Estudiando cada elemento arquitectónico y la interrelación entre ellos desde un punto de vista de cambio de función, forma, posición o utilidad dentro del recinto en cada momento temporal espacial.

\footnotetext{
${ }^{6}$ Agustín Berque investiga la relación profunda entre el territorio y sus habitantes, entre la Tierra y el ser humano. Describe y estudia los paisajes por medio de la comparación de las diferentes visiones del mundo.

${ }^{7}$ Enumera en su libro Les Raison du paysage, págs. 34-35, los criterios de la existencia del paisaje como tal: Representaciones lingüísticas, representaciones literarias, representaciones pictóricas y representaciones jardineras. Solo en las sociedades propiamente paisajeras se encuentran a la vez los cuatro criterios y son también las únicas en presentar la representación lingüísticas. 8 Berque, Agustín. El pensamiento paisajero. Ed.Javier Maderuelo. Biblioteca Nueva, 2009. P.21
} 


\section{_La memoria acota un espacio y tiempo determinado}

"Somos nuestra memoria, somos ese quimérico museo de formas inconstantes, ese montón de espejos rotos". ${ }^{9}$

La memoria permite ordenar, almacenar y recuperar los conocimientos y datos del pasado. Surge de las conexiones sinápticas entre las neuronas, entre el pasado y una acción en el presente. Por esta acción se permite retener experiencias pasadas y recuperarlas en nuestra actualidad. En el proceso de esta acción, se pueden diferenciar tres fases: la codificación o registro, el almacenamiento, y el hecho de recuperación o recordar. Recordar es un diálogo entre el pasado y el presente, un hilo que pone en relación un hecho anterior y lo recupera para traerlo a un momento posterior.

En los últimos años, como así pasó con el término paisaje, la cuestión de la memoria, ha ocasionado la aparición de numerosos estudios, investigaciones y debates. El concepto de la memoria, debido a sus múltiples dimensiones y significados, suscita la interferencia entre diversos campos académicos. El interés por un tema que antes era exclusivo de filósofos, historiadores o psicólogos, ahora se ha extendido a otras disciplinas, como las ciencias sociales o humanas. Incluso ha aparecido un nuevo concepto llamado "estudios de la memoria" refiriéndose a un campo multidisplinar que ampliamente han explicado los profesores de Psicología de la Washington University School, Roediger Y Wertchs ${ }^{10}$, en su artículo 'Collective memory: Conceptual foundations and theoretical approaches'.

Más en concreto este estudio de la memoria: la memoria individual versus la memoria colectiva (recuerdo colectivo) tiene como objeto examinar las formas y funciones de representar el pasado. Con el objetivo de delimitar el panorama conceptual que enmarca las discusiones de la memoria colectiva, para ello propone dos conceptos enfrentados y opuestos: la memoria colectiva frente al recuerdo colectivo; la historia frente a colectivos. En el mismo artículo se nombra a Yadin Dudai11, como el que delimita el término "memoria colectiva" por medio de tres entidades: un cuerpo de conocimiento, un atributo, y un proceso. Estas tres entidades captan algunos de los distintos (pero no todos) sentidos de la

\footnotetext{
9 Cita atribuida a Jorge Luis Borges

10 James V. Wertsch y Henry L. Roediger. Article Memory, perteneciente a su libro 'Collective memory: Conceptual foundations and theoretical approaches', 2008 Washington University School. 11 Yadin Dudai, Profesor de Ciencias Neurológicas en la Universidad de Nueva York ( NYU), cuya investigación se ha centrado en la memoria como concepto y como una facultad del cerebro, en la memoria colectiva, y en la persistencia de la huella y de la evolución en el papel de conceptos de la memoria.
} 
memoria colectiva, siendo utilizados por los estudiosos de diferentes disciplinas académicas, cada uno desde y para diferentes causar y objetivos.

El proceso como metodología. El proceso como evolución continua de la comprensión de hecho entre el individuo y el grupo; como individuos pueden influir y cambiar la memoria colectiva del grupo, pudiendo el grupo cambiar la comprensión del individuo por la conciencia de ser miembro de ese grupo. Pero en este punto, aquí, lo que nos interesa es la memoria entendida como un proceso evolutivo y metodológico.

Como se ha enunciado anteriormente, el vocabulario, definiciones y clasificaciones en torno a la palabra "memoria", más la diversidad de calificativos y sobrenombres, se han multiplicado en los últimos tiempos hasta llegar a un concepto que todo lo engloba. Pero, quizá los motivos que explican este nuevo interés, no solo en España, sino a nivel mundial, podrían ser varios: motivos políticos, de defensa de derechos humanos o simplemente sociales; en especial, el deseo y la necesidad de proteger, mediante relaciones espaciales y temporales, la identidad personal y colectiva frente a la trasformación globalizadora e internacional en la que se está moviendo y desarrollando la sociedad actual. La necesidad de mantener unas bases tradicionales de dicha identidad. ¿Es la tradición todavía importante en nuestra sociedad?

La memoria queda, por tanto, relacionada con el espacio y el tiempo, acotando dichos términos, para buscar una memoria vivida y activa, una memoria del lugar, algo auténtico, espiritual, histórico y tradicional, lejos de lo subjetivo o hipotético de la actualidad. La importancia de la relación de la memoria con el espacio y la temporalidad se ha mostrado en términos y expresiones como lugares de memoria, paisajes memoriales, espacios de memoria, itinerarios y caminos de memoria y un largo etc. de combinaciones como éstas. La mayoría de estos términos se han vinculado, y más en España, con la relación de la memoria colectiva, los paisajes y lugares y las identidades nacionales $i$ Es la memoria, por tanto, un concepto de identidad?

Frances Yates en su primero capítulo del libro de "El arte de la Memoria"12, diferencia dos tipos de memoria, una natural, la otra artificial. La memoria natural

\footnotetext{
12 Ediciones Siruela, 2005 : Surgida al mismo tiempo que la filosofía, el arte de la memoria fue creada por el poeta Simónides de Ceos hacia el año 500 a. C. Desde entonces formó parte de la educación en las escuelas del mundo griego y romano. Mientras que el estudio de la filosofía proporcionaba los medios para manejar adecuadamente los conceptos, la mnemónica se proponía la función no menos importante de enseñar a utilizar las imágenes mentales (imagines agentes) y la carga emotiva adherida a ellas a fin de potenciar los procesos de rememoración, facilitar las operaciones intelectivas y contribuir a la plasmación de la personalidad... Caída en el olvido desde el siglo XVIII, 8
} 
es aquella que nace y se origina con el pensamiento, está en nuestras mentes. La artificial es la memoria que ha sido desarrollada y estructurada por el ejercicio. Esta última, ejercitándose, puede perfeccionar la memoria natural, e incluso las personas menos dotadas a nivel genético, pueden ampliarla y desarrollarla.

La memoria artificial está fundada en lugares e imágenes [Constat igitur artificiosa memoria ex locis et imaginibus], definición fundamental que se ha de repetir siempre en las diferentes épocas. Un locus es un lugar que la memoria puede aprender con facilidad, así una casa, un espacio rodeado de columnas, un rincón, un arco, u otros análogos. Las imágenes son formas, marcas o simulacros [jormae, notae, simulacra] de lo que deseamos recordar....

El arte de la memoria es como un alfabeto propio de quien lo conoce y aprende las letras. Pueden escribir lo que sabe, conoce o le cuentan y leer lo que han escrito. Del mismo modo, quienes han aprendido a recapitular y recordar, pueden poner en lugares lo que han oído y sacarlo de la memoria, suya o de otros.

$\ll<$ Pues los lugares son muy parecidos a tablillas de cera o de papel, las imágenes son como letras, la colocación y disposición de las imágenes como el guion, y la dicción es como la lectura.»13

Pero la memoria también se relaciona con el lugar y su forma. Esa forma que posee significados, pero que antes hay que recordar. Como diría Frances Yates en el mismo libro sobre el estudio de la nemotecnia y sus principios generales:

El primer paso es imprimir en la memoria una serie de loci o lugares. Por lo común, aunque no solamente, se emplea como sistema de lugares mnemónico el tipo arquitectónico. ... sacando de los lugares memorizados las imágenes que ha alojado en ellos. El método asegura el orden correcto en que se han de recordar los puntos, ya que la secuencia de los lugares dentro del edificio fija el orden. ${ }^{14}$

la mnemónica se ha convertido en foco de atención gracias, en buena parte, a Frances A. Yates, que en este libro ha narrado, de forma luminosa, la historia de este arte singular. Por su originalidad se destacan los capítulos... y las relaciones de la mnemónica con la pintura y la arquitectura. (Sinopsis)

13 Yates, Frances Amelia. El arte de la memoria. Siruela, 2005. p. 22 y 23

14. Yates, Frances . Op.cit p.20 


\section{_El lugar posee significados que hay que analizar y descubrir.}

Los lugares siempre han estado vinculados con el estudio o el contenido territorial. Hasta el siglo XIX la Geografía era la encargada de ellos y paso a considerarse la ciencia del paisaje. El paisaje expresaba, exteriorizaba y definía la disposición, forma y figura que toman los hechos geográficos. Pero fue la geografía humana la que definía las formas de vida y aumentó los caracteres, subjetivos, culturales y perceptivos del paisaje. De modo que el paisaje no era solo territorio sino que ahora iba inseparablemente unido al concepto cultural.

El territorio y el paisaje puede a veces confundirse, ya que su frontera o la línea que los separa, es difusa, ya que ambos están interconectados, y esa conexión se debe a que todo territorio se formaliza en paisaje y toda base del paisaje se explica y se interpreta por su estructura territorial.

El paisaje es esa realidad que muestra en convergencia , en asociación, en organización los signos de las fuerzas que lo fabrican. La geografía de los lugares es así compañera del tiempo, en le que las cosas se ordenan y desordenan. ${ }^{15}$

Hay elementos físicos como montañas, valles, ríos... elementos urbanos como calles, puentes, parques, edificios... que son medibles, cuantificables y, por tanto, pueden ser descritos o representados en documentos, dibujos, planos o fotografías. Estos elementos son el "substrato físico" de lo que entendemos por paisaje. Todos estos elementos se encuentran en el paisaje, se encuentran en un continuo conflicto entre orden y desorden, entre artificio y naturaleza, o entre geometría y biología, todos laten en los paisajes construidos.

Para nombrar el conjunto de esos elementos utilizamos el término "paraje" que designa un sitio o lugar dispuesto de una manera determinada. Pero, para que esos elementos antes nombrados adquieran la categoría de paisaje, para poder aplicar con precisión ese nombre, es necesario que exista un ojo que contemple el conjunto y que se genere un sentimiento, que lo interprete emocionalmente. 16

En el estudio de los lugares y de sus formas, y en concreto, de los lugares o paisajes donde la memoria es un atributo más en su formación y desarrollo, (paisajes simbólicos, patrimoniales o históricos) se ofrece un estudio novedoso y una exploración diferente. Ofrece ser un ámbito para estudiar cargado de una riqueza multidisplinar con la capacidad de unir temáticas que en otros lugares sería imposible.

\footnotetext{
${ }^{15}$ Martínez de Pisón, Eduardo. El paisaje patrimonio cultural. Paisaje y Teoría. Biblioteca Nueva. p.73 16 Maderuelo, Javier. Aquello que llamamos paisaje, Op cit. p. 25. 


\section{LA INTENCIÓN, EL ESPACIO-TIEMPO Y EL SIGNIFICADO}

\section{_La intención}

Pero volviendo al paisaje y a su interpretación, los lugares son, por tanto, apreciados, admirados y estudiados por la infinidad diferente de sus capacidades o cualidades. La intención de encontrar y descubrir esas cualidades estéticas, naturales, divinas o la capacidad sobrecogedora del lugar, son las que nos llevan a analizar un pasaje utilizando una mirada diferente, científica y arquitectónica. Muchos paisajes naturales y otros muchos también urbanos son poseedores de una gran belleza; han sido objetos de veneración, que se han expresado a través de sus cualidades misteriosas u ocultas hasta un determinado momento. Los lugares se sacralizan, se convierten en paisaje cuándos se superan los conceptos de valor físico y de utilidad.

Es la diversidad lo que genera un lugar, la dualidad entre el mundo natural y el mundo construido, lo mutable de lo perecedero, lo nuevo de lo antiguo, la ruina de lo rehabilitado. Y es lo que explica y define la cualidad paisajística de un conjunto heterogéneo.17

Hay tres conceptos o palabras que, según Javier Maderuelo en su artículo "Aquello que llamamos paisaje", son las que definen las cualidades paisajísticas de un conjunto heterogéneo. Las palabras son: "entrelazar", "lugar" y "misterio". Si existen estas tres palabras, existe un paisaje de diversidad y contenido.

- Entrelazar_..."solo se puede hablar del paisajes cuando existe "trabazón", cuando la diversidad que forman diferentes elementos que se ofrecen a nuestra contemplación aparecen "enlazados", "trabados" 18 ... No se refiere a una unión simplemente física de los elementos naturales al suelo, sino a las leyes ajenas al control humano que se han generado allí. Ese entrelazado hay que buscarlo por tanto un poco más allá de solo la naturaleza en sí.

Si utilizamos los conceptos espaciales, terminología específica y el conocimiento militar, entrelazándolo con lo nuestra forma analítica formal de estudiar el terreno desde el punto de vista arquitectónico, el resultado es una concepción diferente. La mirada de un militar será siempre distinta de un topógrafo, de un geógrafo, de un biólogo o de un ingeniero o arquitecto.

\footnotetext{
${ }^{17}$ Maderuelo, Javier. "Aquello que llamamos paisaje”. Op cit p. 20-25.

18 José Sancho Comís en el artículo de Javier Maderuelo. Aquello que llamamos paisaje. "Visions", Diciembre 2003, núm. 2, p. 20-25.
} 
Es en estos lazos, entre la mezcla de materias y disciplinas es cuando podemos descubrir cosas en común y otra nuevas que son generadas por la unión y la relación de ambas disciplinas". 19

- Lugar_ En los idiomas de raíz latina y en los anglosajones el concepto "lugar" se haya intrínseco en el concepto del "paisaje". En todos los idiomas occidentales el concepto "paisaje" hace referencia al lugar, atendiendo a sus terminaciones “..aje”, “..scape”.

Si tenemos en cuenta que el lugar es en sí algo que no se puede separar de la palabra paisaje, que es el que lo nutre, se entenderá mejor, (y por ello adelantamos, nuestro ámbito de estudio) que La Ciudad Universitaria de Madrid, no fue sólo en un determinado momento un simple proyecto arquitectónico en medio de un campo de batalla propiamente en sí, sino el único lugar periférico urbano que se reconvirtió en una zona fortificada e impenetrable durante más de tres años. Un lugar único como paisaje, que había sido de carácter docente y universitario hasta que un hecho o evento, como una confrontación durante una guerra, hizo de éste un lugar diferente temporalmente y con consecuencias proyectuales posteriores sin igual.

En cualquier caso, al final el resultado de esta historia sobre como una de las más bellas ciudades universitarias del mundo acabó en ruinas salpicadas de trincherones, embudos e minas y muertos, ya solo lo puedes juzgar tu lector...20

- Misterio_ El paisaje toma sentido completo cuando el lugar unido o trabado, de elementos diversos que lo conforman, está dominado o caracterizado por lo "misterioso". Teniendo en cuenta el sentido religioso e íntimo que contiene esta palabra y la cualidad secreta a la que se refiere. Desde el punto de vista metafórico, sería una cualidad relacionada con la revelación de verdades ocultas.

La confrontación siempre ha sido un tema de análisis, de misterio y de atracción para el pensamiento humano. Hay estudios que analizan la lucha o la pugna entre dos seres, como un aspecto universal, como un aspecto ancestral de la naturaleza humana, mientras que otros sostienen que sólo es resultado de circunstancias socio-culturales o económico-políticas.

Se podría afirmar que la frecuencia y la existencia casi universal del enfrentamiento (se intentará en lo posible evitar la palabra "guerra", ya que está

\footnotetext{
${ }^{19}$ Ideas y formas de entender la visión de un mismo lugar. Conversación mantenida con Fernando Calvo González-Regueral sobre la diferencia entre la visión arquitectónica y la militar.

20 Calvo González-Regueral, Fernando. La Guerra Civil en la Ciudad Universitaria. La Librería. 2012 p. 17 
connota un hecho mas genera, nacional y lejano ) además de ser intrínseca en la naturaleza del hombre, conlleva una necesidad y una satisfacción personal de pertenencia al grupo, a la comunidad. Por lo tanto, como diría Lawrence L. LeShan ${ }^{21}$ en sus escritos sobre la guerra y la psicología: ¿Cómo ser al mismo tiempo un individuo y algo más grande que uno mismo?

Aquello que traba los elementos físicos de un lugar hasta hacerlos paisajes es lo misterioso, es decir, lo revelado a través de la poética, lo reservado, lo subjetivo, lo interpretativo. Efectivamente, solo hay paisaje cuan hay interpretación y esta es siempre subjetiva, reservada y poética o, si se quiere, estética. ${ }^{22}$

\section{_Espacio- Tiempo}

Las formas van creando en el proceso proyectual una sección, un palimpsesto, de profundidad variable con un valor que se obtiene tanto de su acumulación, ordenación, clasificación como de la elaboración de discursos o procesos independientes en cada de los estratos.

Tanto la sección como cada uno de los estratos son "encapsulamientos" que generan lo que se puede entender como mecanismos diferentes: formas ortogonales ordenadas de un proyecto, formas de trama y de sustento de fondo, posicionarse encima de nuevas formas de protección, fortificación; capas sucesivas que conforman los proceso que dan lugar a edificios, construcciones, calles, espacios que ya han desaparecido y que algunos quedaron solamente en la memoria, pero que han llegado a nosotros, como conocimientos o pasado, por la extensa cantidad de planos, documentos, actas, fotos e informes que se generaron.

Sin embargo, este sumatorios de cambios, trasformaciones o procesos, que la hacen ser un lugar único bajo una diferente mirada, podrían analizarse de manera independiente, o incluso modificar el orden de su posición. Pero para ello, para crear la matriz base o fundamento donde superponer dichos estratos, hay que ir a los orígenes más primitivos, porque la historia, los hechos y las acciones previas que dieron lugar al territorio donde se produjeron y asentaron dichos procesos también la han hecho ser parte de lo que se ha convertido.

\footnotetext{
${ }^{21}$ Lawrence LeShan, psicólogo y profesor de la Universidad de Chicago. Escritor sobre una gran variedad de temas, entre los que se encuentran la psicología, la guerra o la psicoterapia. La cita hace referencia a sus escritos en el libro La psicología de la Guerra: La comprensión de su mística y su locura. Andres Bello, 1992.

22 Maderuelo, Javier. "Aquello que llamamos paisaje”. Op cit p.23
} 


\section{_ Significado}

Es por ello por lo que utilizando estas tres palabras (entrelazar, lugar y misterio) se podrá llegar a explicar y demostrar, cómo el paisaje se impregna al lugar, se entrelaza con él; generando elementos de misterio entre lo pasado y lo presente, la ruina y la memoria, lo que era y lo que pudo ser, una tipología nueva de paisaje, verificable a través del estudio de lo que allí ocurrió y la documentación que ha llegado hasta nosotros.

En el último siglo nuevos estudios, investigaciones e interpretaciones, han dado lugar a nuevos significados, ampliando el campo de estudio, entorno al paisaje, y más concretamente en torno al paisaje bélico, paisaje del recuerdo o de la memoria. ${ }^{23} \mathrm{El}$ paisaje no solo como algo que representa un medio físico, sino como algo que se encuentra fuera de nosotros y nos rodea, pero que están intrínsecamente relacionado con nosotros, con nuestra historia pasada y la forma de mirarlo o contemplarlo.

Ante nuestros ojos se abre un campo visual que muestra el mundo en toda su variedad y complejidad. Pero no ha sido fácil aprender a ver ese mundo complejo y diverso, mucho menos conocerlo. Por esto surgen algunas preguntas: ¿cómo hemos ido descubriendo la tierra?, ¿cómo se han ido apreciando y valorando sus entornos y paisajes? y ¿cómo el hombre ha pasado de la mirada sobre sí mismo a observar, disfrutar y comprender los fenómenos que nos ofrece el mundo físico que nos rodea? Preguntas que constituyen algunos de los grandes retos a los que hoy debemos responder cuando queremos saber sobre el paisaje ${ }^{24}$

En el presente estudio sobre la evolución espacio-temporal de La Ciudad Universitaria de Madrid como espacio docente universitario o campus ${ }^{25}$, se pretenderá combinar el estudio de las trasformación del lugar con otros puntos de vista que entremezclarán los sucesivos planteamientos o cambios económicos, sociales y culturales que materializan, más tarde, la diversidad de arquitecturas, construcciones, paisajes y espacios de todo su entorno.

\footnotetext{
${ }^{23}$ Términos nuevos que han surgido y se han popularizado a finales del siglo XX y que se explicará más detalladamente en este mismo capítulo en epígrafes posteriores

${ }^{24}$ Maderuelo, Javier. "Aquello que llamamos paisaje”. op. cit. p.21

25 Termino urbanístico y arquitectónico del que se explicará su origen y correcta utilización en el capítulo 2 de esta tesis. La Ciudad Universitaria de Madrid es el primer recinto universitario moderno que se realizó en España con la adaptación de esta tipología, creada para la Universidad Central, en terrenos cedidos por Alfonso XIII y con la intención de que se convirtiera en la obra de su reinado comenzando a planificase en 1926.
} 


\section{C.1.2_ DUO-POLIS- SINTAXIS ENTRE DOS ÁMBITOS.}

CIUDAD COMO FACHADA

La Ciudad Universitaria de Madrid (a partir de ahora podrá ser nombrada sólo con la abreviatura Ciudad Universitarias o CUM) es una zona de trama de la ciudad del mismo nombre, que se ha mantenido independiente de la ciudad que la acoge, bajo una articulación zonal y una articulación lineal, como zona acotada y delimitada bajo un perímetro imaginario, pero no físico- materia y con un trazado académico de ejes ordenadores en su conformación interna. Todo esto sumando a la contraposición de arquitecturas, edificaciones y construcciones que recoge en su interior la hace ser un englobado de espacios de dualidades y binomios, desde su origen.

Esta dualidad o mezcla de estilos desde su configuración inicial pudo venir dada por la variedad y momentos de visión de diferentes realidades que sufría la sociedad en aquel momento ${ }^{26}$. Una "ciudad" propia, articulada y conectada con otra urbe mayor, en algunos momentos de su desarrollo proyectual, con intención o trazas con intención de unirse, otras de continuar separada, pero siempre autónoma e independiente. Una parte de la ciudad, que surgió y se diseñó bajo unos ejes como las ciudad de origen latino (con ejes ordenadores) ${ }^{27}$ frente o junto a una ciudad-polis griega ${ }^{28}$ (con crecimiento concéntrico y agregativo), pero como con un cinturón o espacio de vacío verde, cerrando la parte de la corona que le faltaba al desarrollo de la capital.

Funcionaba también como una dualidad clásica-moderna en su diseño y como una dualidad de la nueva vida estudiantil que se impondría en esa parte de la ciudad. Una mezcla de Modernidad (en su trazado) y Clasicismo (en sus edificaciones). Y una dualidad de vida de estudio y trabajo junto con deporte y naturaleza. Era una suma y superposición de ideas, trazados y arquitecturas.

-Dualidad polis (Polis griega + Polis latina)

-Dualidad estilística (Trazado clásico + Construcciones modernas)

-Dualidad espacial arquitectónica (Llenos + Vacíos)

-Dualidad de espíritu (Estudio +Deporte- Collage + Sports)

\footnotetext{
${ }^{26}$ No hay que confundir esta dualidad y contraposición inicial, con la dualidad y variedad actual propia del paso y el desarrollo urbano que ha sufrido la Ciudad Universitaria.

27 El cardo con dirección norte-sur, y el decumano, con dirección este-oeste.

${ }^{28}$ Ciudades con procesos de agregación de núcleos y grupos anteriormente vinculados. Ciudad amurallada en torno a un centro o espacio de relación.
} 
Una secuencia y un superposición que se analizará, empezando en este capitulo por las preexistencias al proyecto de generis, tanto a nivel histórico de manera secuencial (lineal) como a nivel arquitectónico (sumatorio) como una superposición de estratos y que han configurado la esencia del lugar.

Una de las mayores investigadoras y conocedoras de La Ciudad Universitaria de Madrid es Pilar Chías ${ }^{29}$. Su conocimiento histórico, proyectual evolutivo, y arquitectónico, como parte del desarrollo y planeamiento de la gran urbe que la contiene, la hace "la gran conocedora" de toda la elaboración, desde sus orígenes hasta lo que se ha llegado a cristalizar en el último cuarto del siglo XX, como un ente reducto independiente de la ciudad. Esta tesis se desarrolla sobre la idea de que el planeamiento y proceso de decisiones, que configuraron el recinto, se configuró como una cristalización de la política social y urbanística que germinó en España desde 1927 hasta la actualidad. La autora, no olvida tampoco, en la evolución del conjunto, la decisiva influencia que tuvo la caída de la Monarquía, la herencia de la Segunda República, el desconcierto político y social que confluyó en la guerra y la imposición del posterior régimen dictatorial ${ }^{30}$ junto con la posterior gestión y financiación del proyecto y sus consecuencias, ocasionando la pérdida de coherencia del conjunto. Un desarrollo que según ella (corroborado en su tesis con infinidad de planos, notas, fuentes y datos documentados) está desarrollado bajo la gran interrelación entre la política social y urbanística que seguía en todo momento, el proceso del proyecto y su ejecución material.

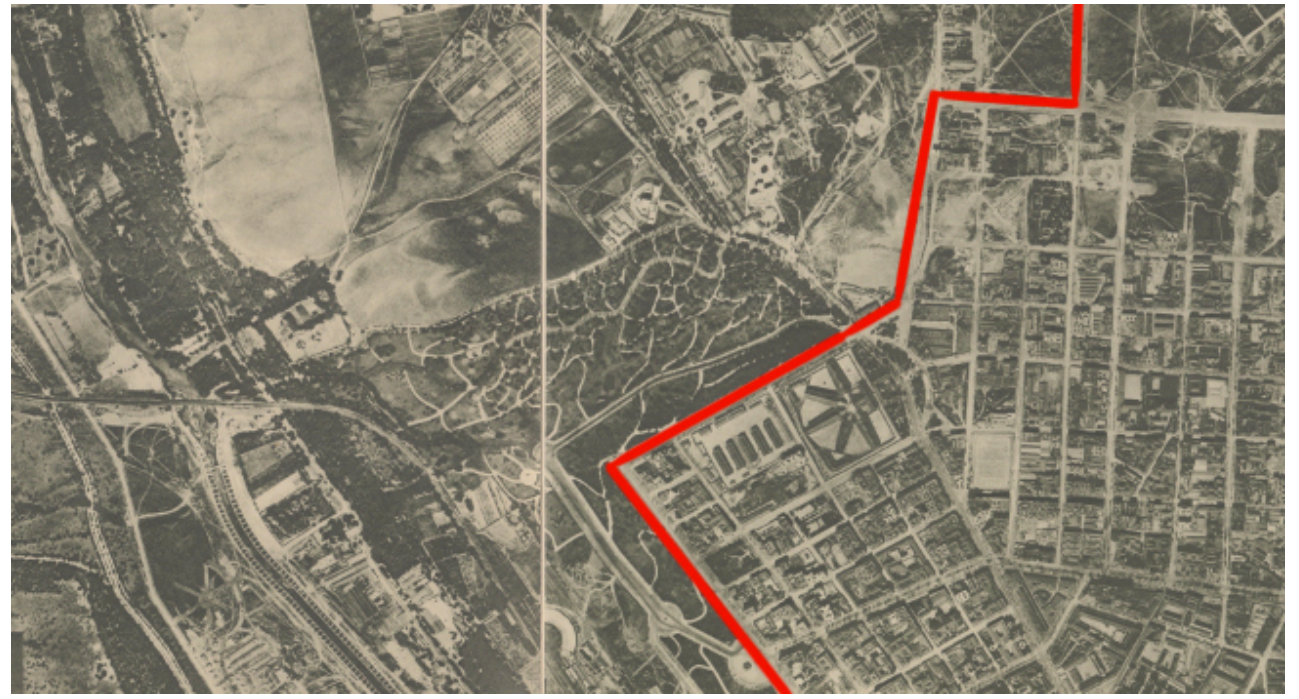

Fig. 1. Fotografía aérea 1927- Limite de dos ámbitos de la ciudad de Madrid (modificada)

\footnotetext{
${ }^{29}$ A lo largo de este trabajo se harán referencia a datos, estudios y conclusiones de esta arquitecta, ya que es ella la realizadora del más amplio y profundo estudio sobre este ámbito.

30 Sin olvidar la gran influencia que tuvo la Junta o la Oficina Técnica, que a persa de su heterogeneidad de estilos e ideologías, tomaban las decisiones de manera unilateral. 


\section{C.1.2.1_LA METRÓPOLI DE PRINCIPIOS DE SIGLO.}

Madrid a principios de siglo XX es una nueva metrópolis, se había convertido en una ciudad cosmopolita, una ciudad renovada y privilegiada. ${ }^{31}$ Con casi un millón de habitantes, como las grandes ciudades y metrópolis europeas, comienza en esta época la llamada "edad de plata" en la arquitectura y urbanismo español, aportando grandes cambios a su configuración urbana y a su funcionamiento. En una avance de proyecto urbano de organizar y relacionar el centro de la urbe con la periferia, aparecen nuevas infraestructuras como el metro, nuevas construcciones de colonias de vivienda unifamiliares en la zona del ensanche (Ciudad Jardín, Puente de Vallecas o Tetuán de las Victorias, son algunos ejemplos) y se crean o se proyectan espacios urbanos nuevos como la Colonia de los Chopos o lo que será la futura Ciudad Universitaria de Madrid, a la vez que se decide que el crecimiento de la capital debe cambiar de este a norte, con la ampliación de la Castellana y el plan Zuazo-Jansen. ${ }^{32}$

La operación de crear y conectar mediante el metro el centro con la periferia, favorecía y apuntaba la actividad de dedicar terrenos para la creación de viviendas. El metro se inauguró en 1919 con la línea Sol- Cuatro Camino de mano de la Compañía Urbanizadora Metropolitana, quien compró ese mismo año los terrenos próximos a la finca de La Moncloa, configurando la ronda del ensanche con la creación de bloques de vivienda colectiva desde la Avenida de Reina Victoria $^{33}$ hasta el Parque Metropolitano ${ }^{34}$. Dejando una zona de vacío entre la avenida y Cea Bermúdez que sería urbanizado más tardíamente (después de la guerra por su proximidad a La Ciudad Universitaria) y con un tejido y estilo urbano o social diferente del conjunto del Barrio de Argüelles.

Una ciudad que crece, tanto en población como en dimensiones, donde las colonias de vivienda unifamiliar no eran solo experimentos de descentralización al estilo o anglosajón o europeo, sino actuaciones dispersas por diferentes promotores o gremios como nuevas formas de ocupar el suelo. Ejemplo de ello,

\footnotetext{
31 Seguramente en parte debido a la posición de neutralidad de España en la I Guerra Mundial.

32 En 1928 el Ayuntamiento de Madrid convoca un concurso internacional de ordenación de la Ciudad de Madrid. El Plan ganador es el presentado por los arquitectos Zuazo y el urbanista alemán Jansen, ya que respondía claramente a la cultura urbana europea del momento aplicada a la zona territorial de Madrid de forma clara y con un modelo radio-céntrico.

33 Dirigida la clase media acomodada y profesionales liberados, como se construía análogamente en el extranjero, un parque urbanizado con hoteles rodeado de jardines y huertas.

34 Parque urbanizado de viviendas unifamiliares de unas 20 hectáreas para uso delos trabajadores de la compañía que trabajaban en la construcción del metro. Dirigida también a la clase media acomodada y profesionales liberados.
} 
además de la Ciudad Lineal, fue la rápida proliferación de vivienda social en Madrid durante la dictadura de Primo de Rivera (1923-1930). Esta tipología de vivienda quedó reglamentada jurídicamente para permitir y favorecer un desarrollo ordenado y evitar la conflictividad social, llamándose, la "Ley de Casas Baratas"35 y "Ciudades Satélites" 36 que favorecieron desde 1922 el crecimiento de colonias residenciales en Madrid con más de medio centenar en los últimos momentos de la Monarquía. ${ }^{37}$ Con la Republica se harían también construcciones de nuevas colonias, pero evolucionando hacia clases acomodadas, estando situadas en terrenos no tan alejados y más próximos al ensanche. 38
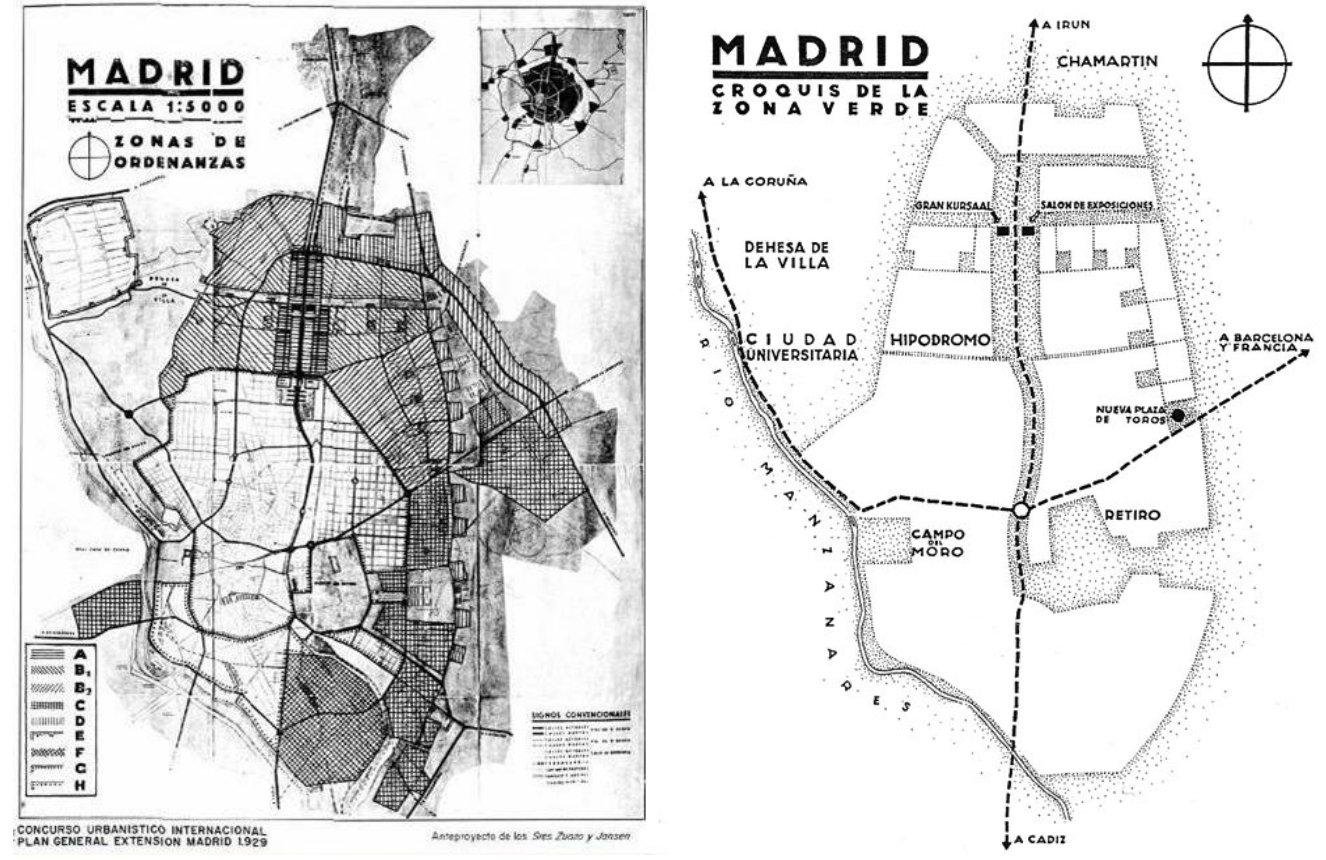

Fig.2. Mapas de Madrid. Zuazo Jansen. Zonas de ordenanzas. Fuente: www.urbannetworks.blogspot.com Fig. 3 Mapas de Madrid. Zuazo Jansen. Croquis de zonas verdes y principales conexiones de salida y de zonas. www. Madrid .es

\footnotetext{
${ }^{35}$ A partir de 1911 se promulgan la primera Ley de Casas Baratas, en 1921 se aprueba la segunda Ley de Casas Baratas y en 1925, durante la Dictadura de Primo de Rivera, en se hace extensiva a la clase media.

36 La aparición de las ideas de ciudad jardín y de ciudad satélite en el terreno de la teoría urbanística, así como la realidad de la forma de realizarse la urbanización que se estaban dando, estaban conduciendo a la necesidad de ampliar la forma institucional el problema del crecimiento periférico de las ciudades.

37 "La colonia de Prensa" (1911-1916), "La Ciudad -Jardín Alfonso XIII"( 1915-1924), "La colonia Socialista" (1919-1920), "Ciudad Jardín del Norte” (1923-1929), "La colonia de Prensa y Bellas Artes" (1926-1928), “Los pinares (1926-1928) “Los Cármenes” (1926-1928), “Cruz del Rayo” (1927-1928),” Maudes” (1928-1929), “Albéniz" (1928-1934) "Fuente del Berro" (1925-1926), “El Pico del Pañuelo" (1927-1930), “San Fermín" (1925-1930) “Colonia Manzanares” (1928-1929) y "La Colonia Militar" (1919-1922).

${ }^{38}$ Colonia "Parque-Residencia (1931-1933) y “El Viso" (1933-1934) por Rafael Bergamín y Luso Blanco Soler, con marcado estilo racionalista.
} 
El proyecto de crear una recinto universitario en la zonas de la Moncloa y la Florida, siempre fue un proyecto arquitectónico y urbanístico independiente de la ciudad de Madrid y apenas es nombrada en los grandes planes ordenadores y de ampliación de la capital (Plan de Núñez Grañez de 1910, Plan General de Extensión y el de Gran Vía). Si se puede ver intuida y nombrada en el plan de Zuazo-Jansen como una prolongación de las arterias urbanas y en relación a las zonas verdes. Siempre fue un proyecto independiente, tanto en ideación, concepción y financiación, como se verá mas adelante, como desde el punto de vista de ubicación, relación y conexión con la ciudad anexa a la que pertenecía, pero de la que seria muy diferente.

Aunque se barajaron posibles zonas de implantación, como más tarde se comprobará y explicará en este mismo capítulo, la finca de La Moncloa fue el lugar escogido, en el margen izquierdo del Río Manzanares, al noreste del núcleo edificado de la capital. Un lugar muy discutido por su valor paisajístico y su valor estratégico por su cercanía y conexión con la ciudad.

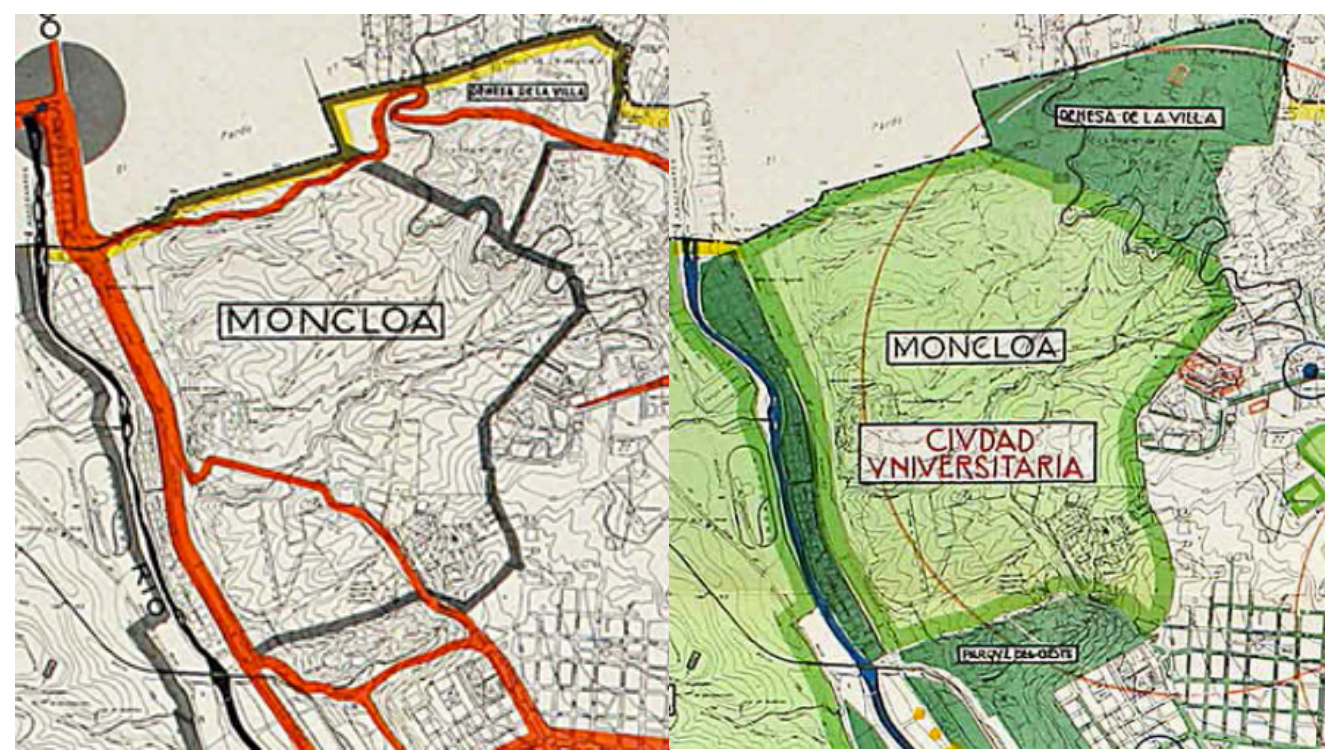

Fig. 3. Plano de Arterias principales de trafico. Fig. 4. Plano de Recreo. Parques y Jardines. Memoria. Madrid Información sobre las ciudad. Año 1929. Ayuntamiento de Madrid. Planos 


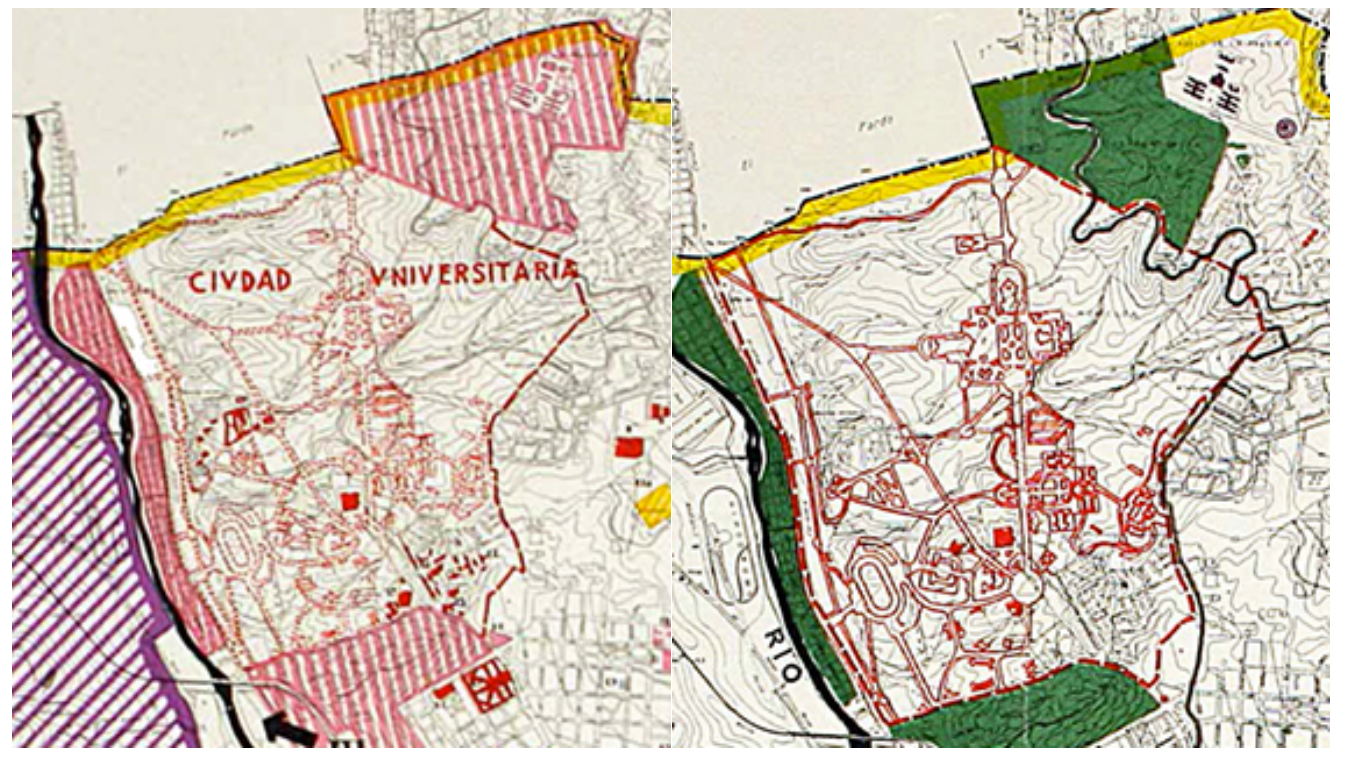

Fig. 5. Plano de Edificios Monumentos y Sitios .

Fig. 6. Plano de Instrucción Publica.

Memoria. Madrid Información sobre las ciudad. Año 1929. Ayuntamiento de Madrid. Planos

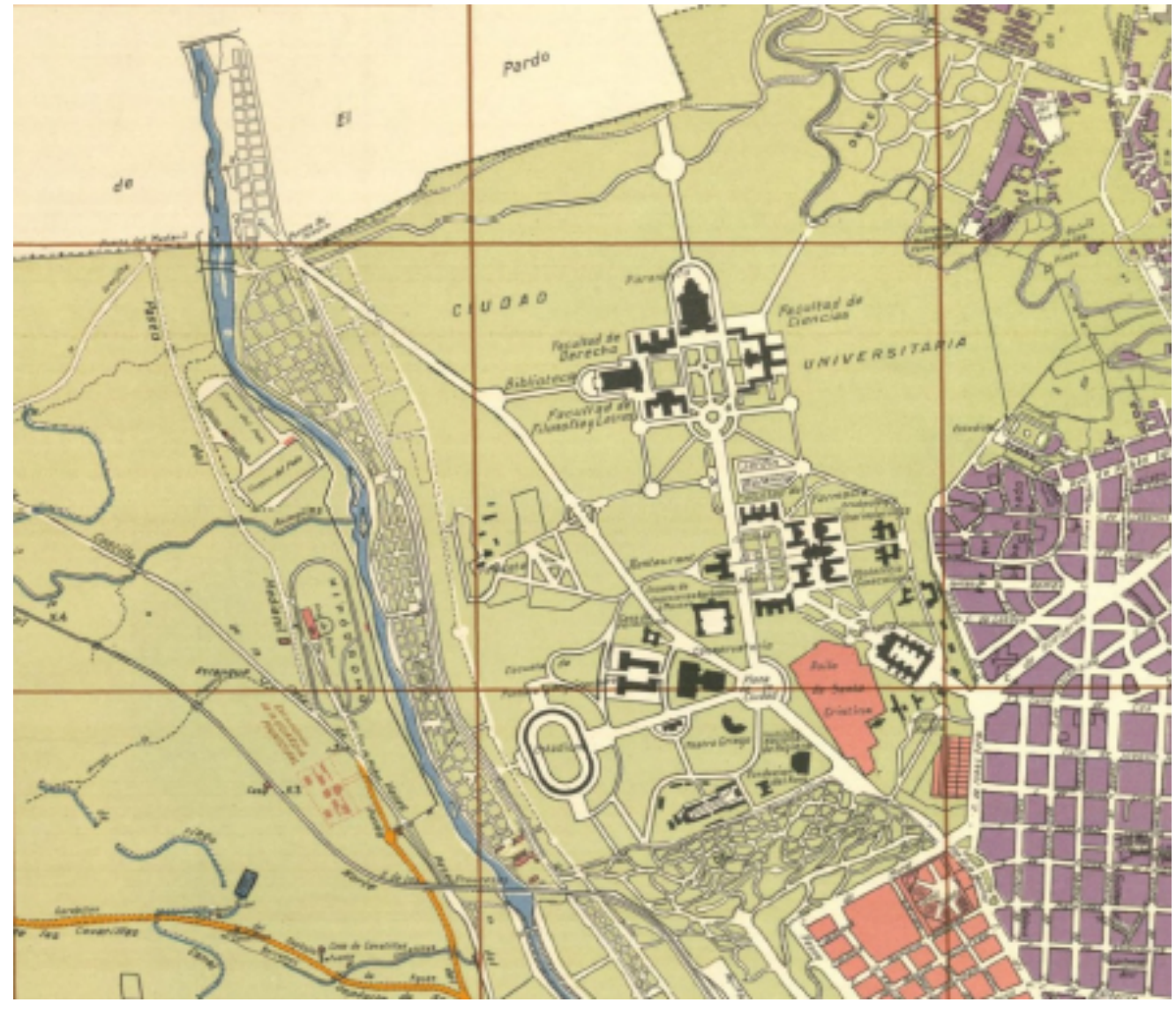

Fig. 7. Plano de Madrid. Plano de vías publicas. 1934. Ayuntamiento de Madrid.

Plano a color realizado por la Sección de Estadística del Ayuntamiento de Madrid, escala 1:14300, plastificado, 125 × 100 cm. Imprenta de las Artes Gráficas Municipales. 


\section{C.1.2.2_ZONA DE ENSANCHE DE MADRID.}

Como la idea que Santiago Amón manifiesta en algunos de sus documentales, la Ciudad Universitaria reflejaba, el contraste y el contrapunto que existe en la totalidad de este lugar, una arquitectura racionalista (de la época más monárquica y continuación de la República) con la contraposición de una arquitectura más imperial y emblemática) ${ }^{39}$ que se desarrolló y se impuso tras la Guerra Civil. Pero la verdadera dualidad surge de la contraposición, de esta ciudad especializada, con la ciudad a la que esta anexa o su ciudad nodriza. ${ }^{40}$

Según lo estipulado en el Congreso de Quito en su carta de 1977, todo núcleo urbano con un centro histórico debe reforzar y prevalecer las ideas de: una estructura fuerte, una identidad histórica reconocible, y su pasado histórico. Un núcleo que debe ser indivisible e inmutable como tejido urbano a preservar y sus edificios históricos cuidados para su no desaparición ni trasformación. ¿Puede considerarse y estudiarse La Ciudad Universitaria de Madrid como una ciudadpolis independiente, donde prevalecen ciertas ideas iniciales estructurales e identitarias propias, como ciudad anexa a otra?

Este coloquio define como Centros Históricos a todos aquellos asentamientos humanos vivos, fuertemente condicionados por una estructura física proveniente del pasado, reconocibles como representativos de la evolución de un pueblo.

Los Centros Históricos no sólo son patrimonio cultural de la humanidad sino que pertenecen en forma particular a todos aquellos sectores sociales que los habitan. ${ }^{41}$

El planeamiento de La Ciudad Universitaria como proyecto urbano y arquitectónico siempre se mantuvo separado e independiente del resto de la ciudad. En sus planeamientos, como el de Núñez Grañez y en sus planes de extensión, nunca se tomó como parte ampliable de la ciudad, y se representaba como una zona intermedia entre urbana y rural con algunos caminos que la recorrían y algunas construcciones dispersas. El carácter de parcelación, rural y natural del paraje era lo más representativo y admirado, y se muestra en el análisis histórico de los planos originales y en orden cronológico de la Finca. Sera nuestro punto de partida para la investigación y el estudio interpretativo del lugar.

Fue una de las más importantes y grandes acciones urbanísticas en la primera mitad del siglo XX de la capital, de manos de la Monarquía. Su forma y creación de

\footnotetext{
39 Programa cultural Trazos de La2 de TVE. "La Ciudad Universitaria”. 1977. Ideas y declara raciones que se explica en el libro El Madrid de Santiago Amón. Ed La Librería, Reeditado en 2006

40 Términos que utiliza Pilar Chías en la introducción de sus tesis, La Ciudad Universitaria de Madrid. Planeamiento y Realización. ETSAM. 1983 p.5 como una cuestión de conveniencia y punto de partida para su estudio.

${ }^{41}$ Carta de Quito. Conclusiones. Punto 1. Párrafo 1 y 4. Definición de Centros Históricos
} 
anexionarse de manera aislada a una ciudad en el borde norte natural, podría deberse a dos motivos diferentes, pero complementarios:

- Uno físico y necesario por los crecientes conflictos que empezaron a surgir en los años finales de la monarquía, manteniendo a la juventud-estudiante lejos, acotada y controlada.

- Otro a nivel espiritual, didáctico y educativo, como la mejor forma de enseñanza y de llegar al conocimiento, en un lugar destinado y diseñado para ello, en una ciudad del saber, independiente. ${ }^{42}$

Quizá es esta idea sea la razón, por la que en el libro del profesor Rico Pérez se nombra y de define al Rey Alfonso XIII como el "arquitecto"43, ya que él fue el verdadero creador y generador de la idea. Su dedicación a España durante sus veintinueve años de reinado se caracterizó entre otras cosas, por su entusiasmo y decisión en la construcción de La Ciudad Universitaria de Madrid. Incluso tras su salida del país, sus alusiones y referencias a ella son constantes en muchos de sus discursos durante su exilio en Roma a partir de 1931, continuando con su idea de dar el proyecto a conocer incluso proclamada la Segunda República en España el 14 de abril del mismo año

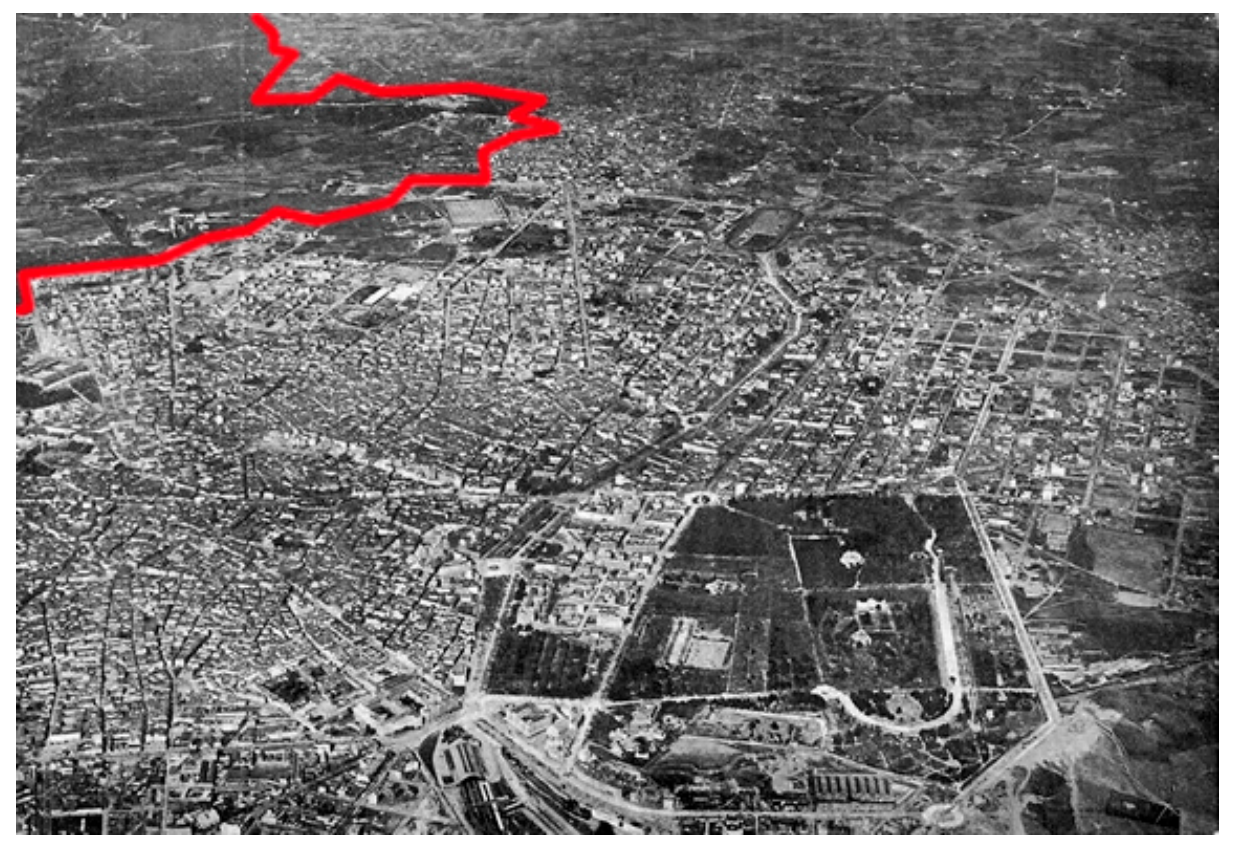

Fig.8. Vista aérea de Madrid anterior a 1923 por la ausencia de la Universidad y el estado de El Parque del Retiro y junto al Museo del Prado, Recoletos y el Paseo de la Castellana, que continúa hasta finalizar en el antiguo Hipódromo de la Castellanas. www.urbancidades.wordpress.com.

\footnotetext{
42 Ideas de aislamiento que afirma y explica Alfredo Lledó en el documental Voces y Formas de la Memoria. La Ciudad Universitaria de Madrid (1927-2006)

${ }^{43}$ Rico Pérez, Francisco. Alfonso XIII Y La Universidad De Hispanoamérica. Fundación Ramos de Castro para el Estudio y Promoción del Hombre, 1982.
} 


\section{C.1.3_ LABORATORIO SOCIAL- POLÍTICO- URBANO DE MADRID}

Las ideas y desequilibrios sociales jugarían un importante papel en cada momento político y por ello también los arquitectos intervinientes en cada momento, como un trabajo de equipo que mostrarían su tendencia o concepción formal tanto a nivel arquitectónico, urbano como político, en cada periodo. La Ciudad Universitaria de Madrid, fue un proceso de proyecto continuo, desde su génesis, que cada poder o sistema de gobierno se hizo propio e intentó mejorar, simplificar o modificar, bajo su modo de ver y sus ideales propias. Un único proyecto que sufrió una variación continúa, gestando la universidad como concepto e institución, pero como un laboratorio donde se investiga o se intenta buscar una solución con diferentes agentes de ideas política y arquitectónicas a veces contrarias.

Según Pilar Chías en su tesis, la situación de convivencia entre arquitectos de diferente generación (1910 y 1925) se mantenía en la mayoría de ocasiones, pero la diferencia de ideologías era tan clara como la de estilos, materiales o técnicas, siendo evidente y así se plasmó en los proyectos y obras desde el comienzo del proyecto. Esto que parecería una contrariedad, dio lugar a la riqueza y la idónea organización formal o zonal como un proyecto de conjunto.

La noción de estilo o tendencia adscrita a cada miembro arquitecto con ciertas coordenadas comunes entre ellos se diluía en favor de un nuevo sistema basado en escenarios de interconexión que propiciaban complicidades intensas. El método de trabajo, estilos de proyecto o visiones del conjunto podían ser muy diferentes, pero los intereses eran claramente afines. Había que hacer un proyecto de gran escala y tenía que existir un orden y sistema jerarquizado de revisión y planeamiento.

Todo su planeamiento estuvo en manos de la Junta fundada en 1927, presidida por el rey y formada por diecisiete miembros de diferentes disciplinas y atribuciones, caracterizándose por su hermeticidad e independencia de las críticas u observaciones de la sociedad sobre la idea que se estaba gestando. ¡Hasta en esto era independiente! Entre los miembro había filósofos, decanos, políticos y dos arquitectos: Luis Landecho y Modesto López Otero. Uno autodefinido como continuador de la tradición de Viollet Le-Duc y el otro más joven, director de la Escuela de Arquitectura de clara influencia más clasicista y secesionista vienesa, como veremos a continuación en el siguiente epígrafe.

En las primeras reuniones, en mayo de 1927, se estableció con carácter urgente que se entregara los primeros proyectos y planos por parte de los decanos y 
arquitectos encargados de en el plazo de 20 días. Para más efectividad la Junta se dividió en cuatro comisiones: Hacienda, Asuntos Generales, Ejecutiva y Obras, esta última se encargaría del diseño y proyecto. Para la Junta Constructora se nombró como director a Modesto López Otero, por su trayectoria profesional y su juventud. Él fue el encargado de organizar y nombrar los miembros-arquitectos para la elaboración de los diferentes proyectos edificatorios de las facultades y escuelas que se necesitaban. Miembros todos de la "Generación del 25".44 La realización del proyecto de urbanización quedaría a manos de esta Oficina Técnica, pero el conjunto de edificios se haría por arquitectos, la mayoría de ellos trabajando o colaborando de manera individual o en parejas.

La citada Junta, fue la encargada del planeamiento y se crearon a su vez dos comisiones entre 1919 y 1927 para la realización del hospital y la zona de pabellones anexa a la universidad. Como se explicará en el segundo capítulos más detalladamente, el planeamiento del recinto universitario de Madrid, se mantuvo siempre independiente de los planes de extensión y ordenación territorial . 45

Según Sofía Diéguez Patao, la Generación del 25 conformaba una elite culta cosmopolita que realizó los primeros contactos con la arquitectura moderna europea, con la idea de terminar con el ambiente cultural, por medio de las obras construidas, de ese desencanto y del camino sin salida en que se encontraba. Fue un acercamiento al Movimiento Moderno, pero también fué una tendencia hacia la modernización gradual, una generación puente entre el academicismo de principios de siglo y el racionalismo ortodoxo de los años 30. Algunos asimilando los cambios mas rápidamente y otros de forma mas continuada, pero siendo esta época de la historia de la arquitectura, subjetiva, contradictoria y a veces contraria entre diferentes arquitectos, historiadores o críticos. 46

La Ciudad Universitaria de Madrid es un ejemplo mas del equilibrio entre innovación y tradición que caracteriza a esta generación. No pueden hacerse una valoración de este conjunto siguiendo los principios del Movimiento Moderno o del racionalismo ortodoxo porque son evidentes las ataduras con la tradición. Aunque en su conjunto intervinieron arquitectos tan representativos de la modernización como Lacasa, Sánchez Arcas, Blanco soler o el ingeniero Torroja, fue un empresa de gran envergadura que nación condicionada por una serie de factores que harán de ella un hibrido entre tradición y modernización. ${ }^{47}$

\footnotetext{
44 Ver datos e ANEXO c1

45 Planes de Núñez Grañez y el Avance del Plan de Extensión - El Gran Madrid

${ }^{46}$ Caso de estudio seria la tesis de Alberto Campo Baeza, sobre la arquitectura madrileña, donde cuestiona las ideas expresados por Flores, Bohígas o Fullaondo, en la revista Nueva Forma, sobre maestros de la escuela madrileña.

47 Diéguez Patao, Sofía. La generación del 25. Primera arquitectura moderna. Cátedra. 1997. p. 275 
Carlos Flores dijo de esta generación que "evocaba el clima de rebeldía que se inicia en la arquitectura hacia 1925". El gran reto de los arquitectos españoles de los años veinte era unir el casticismo y la tradición con la vanguardia y la modernidad. Los viajes al extranjero y loas novedades, noticias libros y revistas, del exterior llegaban del exterior por lo que el ambiente intelectual madrileño, al igual que el político y social , bullía.

La Ciudad Universitaria de Madrid, no solo seria una obra y proyecto posible, sino que seria símbolo de la cultura moderna y los nuevos aires y tendencias artísticas que empezaban a imperar desde principios de siglo.

Era idea del Rey, y así nos lo manifestó expresamente en distintas ocasiones, que la Ciudad Universitaria fuera obra nacional y no estuviera sometida a los vaivenes de la política $^{48}$

Para el arquitecto Francisco de Asís Cabrero, la Ciudad Universitaria de Madrid por sus características de conjunto arquitectónico, prismático, de limpieza en su volumen compositivo, los criterios funcionales de interiores o exteriores, su uso de las estructuras y el uso de materiales con tendencia a la arquitectura limpia de ornamentos, la hacen ser un hecho arquitectónico con el que empieza el Movimiento Moderno en España.

Por ello, mientras en Europa se desarrollaban otras tendencias y estilismos arquitectónicos que en algo influyeron en su gestión y creación, se la puede considerar como una obra arquitectónica y urbanística, con un origen y evolución independiente de las tendencias y cambios que se estaban realizando en aquel momento en Europa e incluso en América, pero quizá con algún rasgo o influencia en su concepción original.

La historia del urbanismo y de la arquitectura española; se puede llegar a comprender y a analizar en cada período, en función de las diferente influencias artísticas, ideológicas y políticas, que se dan lugar de manera coetánea. Pero la mayor característica, o se podría decir, peculiaridad, es que la Ciudad Universitaria de Madrid desde sus orígenes hasta los años setenta, se ha desarrollado y modificando a lo largo de diferentes momentos políticos, ideológicos y sociológicos de la historia con igual impronta, energía y dedicación en cada uno de ellos. Momentos continuos en el tiempo pero discontinuos en valores e ideología ${ }^{49}$.

\footnotetext{
${ }^{48}$ Palacios, Julio , Op cit. p.643

${ }^{49}$ El proyecto del conjunto se aprobó con el apoyo y sustento de la Monarquía en 1926, mas tarde fue heredado por la Republica que heredó y revalidaría sus conceptos y continuidad hasta el comienzo de la Guerra Civil Española. La reconstrucción y ampliación durante la dictadura la devolvió en parte su concepto inicial. Pero fue a partir de los años setenta cuando de manera mas alarmante el
} 
Ha sido la única obra en España que ha puesto de acuerdo a gobiernos tan diferentes como contrarios en ideología.

Por esto último, se pueden encontrar en un mismo conjunto urbanístico y arquitectónico tan extenso, como es la Ciudad Universitaria, desde su comienzo hasta la actualidad, proyectos funcionalistas, junto a ejemplos mas tarde de arquitecturas tachadas de imperialistas o monumentalitas, hasta llegar a experimentos estructuralistas y organicistas de la última época.

Todo un siglo de desarrollo que ha dado lugar a una variedad de ejemplos arquitectónicos y urbanísticos en un área acotada y delimitado como es el campus universitario de "La Universitaria". Vinculando el pasado y los años posteriores a su reconstrucción, hasta la actualidad, la variación de diseños e ideologías representa toda esta acumulación de ideas y movimientos estéticos, que han llegado a conformar un estado actual del conjunto a la vez interesante pero complejo. 


\subsection{1_EL ORIGEN DE ALGO JUSTIFICADO}

España a finales del siglo XIX sufrió dos grandes procesos, relacionados entre sí, que cambiaron la estructura social del país. El crecimiento de la población y el movimiento de la población rural a las ciudades. España era un país empobrecido, mayormente analfabeto y sin casi derechos. ${ }^{50} \mathrm{El}$ sistema político decadente no funcionaba a pesar del gran patriotismo de su rey que le hizo aceptar la oferta del ejército de implantar un Directorio temporal con la dictadura de Primo de Rivera como posible solución.

En 1910, intelectuales como Ortega y Gasset manifestaban su idea de trasformar la realidad mediante la educación. ${ }^{51}$ Fue durante esta época cuando se gestó y se originó la idea de una universidad para Madrid, que daría lugar a lo que hoy se conoce como "La Universitaria". 52

Si educación es la trasformación de una realidad en el sentido de cierta idea mejor que poseemos, y la educación no ha de ser sino social, tendremos que la Pedagogía es la ciencia del trasformar sociedades. ...el problema social es un problema pedagógico. ${ }^{53}$

Es lo que se llamaría "la cuestión universitaria". El rey fue consciente de que toda reforma política, social y económica sería insuficiente sin la profunda trasformación de la enseñanza ${ }^{54}$ El sistema político en 1923 aun siendo ineficaz, intentó llevar a cabo algo de modernización, pareciendo una etapa de relativa prosperidad. ${ }^{55} \mathrm{~A}$ este afán de modernización se sumó la idea de la creación, seguramente por necesidad e interés político, de una nueva zona para los estudios

\footnotetext{
${ }^{50}$ Alfonso XIII es proclamado rey en 1902, cuando tras las regencia de su madre la Reina Maㅡ Cristina, alcanza la mayoría de edad. Una primera época de alternancia de partidos en el poder entre liberales y conservadores, a la que sucederá una época de guerras, como la de Marruecos, huelgas, gobiernos cortos, revoluciones e incluso terrorismo. Claro ejemplo del momento convulso en que vivía el país es que el mismo rey, Alfonso XIII, llego a sufrir incluso tres atentados en su reinado y dos jefes de gobierno fueron asesinados.

51 En esta época casi un 65\% de la población era analfabeta y la cultura era un privilegio de clases. Una década más tarde el monarca pensaba lo mismo y deseaba modernizar el país atajando el origen del problema.

52 Nombre común, utilizado por la población y de manera coloquial, que designa y hace referencia a todo el ámbito que rodea la actual Universidad Complutense, Universidad Politécnica y UNED, entre otras instituciones docentes, que conforman los terrenos del Campus de Moncloa de Madrid.

53 Discurso de Ortega y Gasset sobre la "Pedagogía social como problema político" el 12 marzo de 1910 cit. en Fernández de Sevilla Morales, Miguel. 2009. La Ciudad Universitaria de Madrid: 80 años de historia. Edisofer. 2009. p.23

${ }^{54}$ Fernández de Sevilla Morales,, Miguel. 2009. La Ciudad Universitaria de Madrid: 80 años de historia. Edisofer. 2009. p.24

${ }^{55}$ Se intentó modernizar el país potenciando el nacionalismo como un renacer del imperio pasado español y para ello se realizaron grandes obras públicas para el bien y beneficio de todo el pueblo español.
} 
universitarios, dando esperanza a los estudiantes, que como era normal no eran partidarios de Primo de Rivera ${ }^{56}$ ni de la dictadura instaurada. Estos estudiantes, a la vez desarrollaron un esfuerzo de europeización que se plasmó en nuevas formas intelectuales, filosóficas y estéticas en aquella época. ${ }^{57}$ A estos intelectuales, en la primavera de 1929, se les unió la protesta estudiantil universitaria. Todo ello con motivo del reconocimiento de algunos centros superiores dirigidos por la Iglesia, la renuncia de varios catedráticos y la decisión y publicación, por parte del dictador, del cierre de universidades o facultades, ya que no sería perjudicial para un país en el que existían excesivos profesionales en algunas disciplinas. Contradictorio sería, que sin embargo, apoyara y secundara las ideas de Alfonso XIII para la creación de La Ciudad Universitaria en terrenos hasta ese momento del Patrimonio Real.58

La personal hombría de bien del dictador, su resolución del problema marroquí, su brillante política de obras publica... reforma constitucional, situación del campesinado, el problema catalán, junto con la crisis financiera pusieron fin a al dictadura y también porque no decirlo a la monarquía parlamentaria. ${ }^{59}$

La educación_ La falta de educación y el contexto intelectual de estos años es fundamental para poder entender la necesidad de crear una nueva universidad y analizar cómo y porqué se gestó de la manera en que se hizo. La realidad educativa y docente con el escenario social y político, fueron los causantes de su aparición:

- Es un momento de alto valor intelectual a principios de siglo XX, en parte debido en gran medida a la actividad de Escuelas Especializadas, Ateneos, Centros de investigación o Reales Sitios.

- La cultura y la educación eran privilegio de unos pocos. El porcentaje de analfabetos era en torno al 60\%. Más de la mitad de la población española no sabía leer ni escribir.

- Aunque había un alto grado de analfabetismo, el nivel de cultura creadora se observa por el gran auge del periodismo y de la producción editorial en

\footnotetext{
56 Fue a partir de 1928, al poco de originarse la idea de la Ciudad Universitaria, cuando la dictadura vivió un periodo de decadencia sumando día a día nuevos enemigos. Entre ellos hay que destacar, porque se trata en relación a este estudio, la protesta estudiantil y universitaria, además del sentimiento de desesperanza y descontento del pueblo. Fue una época complicada donde la dictadura podría parecer la única y menos mala de las soluciones.

${ }^{57}$ La Generación del 98 con intelectuales como Unamuno, Machado, Azorín, Baroja, Maeztu, Ortega, Menéndez Pidal, Benavente y la Generación del 27, existían a la par que el subdesarrollo cultural de la mayoría del pueblo español durante estos años.

58 Terrenos originarios de diferentes propietarios que se fueron anexionado por fincas o parcelas hasta conseguir la finca definitiva en propiedad de la corona. Serán los terrenos llamados preexistentes que conformaran el lugar definitivo donde se asentará la nueva universidad. ${ }^{59}$ Fernández de Sevilla Morales, Miguel. Op. cit. p.23 
contraposición al analfabetismo y retroceso en la sociedad a partir de la dictadura de Primo de Rivera.

- La Universidad necesitaba de un marco más moderno y distinto, ya que los planteamientos antiguos y anteriores habían fracasado.

- Se llevaron a cabo importantes acciones culturales como la creación de la Junta para ampliaciones de estudios e Investigaciones Científica en 1907 y la reforma Institución Libre de Enseñanza. 60

La Ciudad Universitaria de Madrid representará el cambio más radical que en los procedimientos docentes se produzca en España ${ }^{61}$

Alfonso XIII, monarca humanista por vocación, asumió y vio necesario la necesidad de cambio de su pueblo con la idea de impulsar la prosperidad. Quiso en todo momento que esas corrientes culturales y científicas que se estaban desarrollando vieran su resultado y aplicación en la sociedad en un proyecto, lugar y edificaciones concreto. El rey mostrará siempre, como se verá más adelante, en el origen y creación del proyecto de La Ciudad Universitaria de Madrid, una gran admiración e interés por los problemas urbanísticos y arquitectónicos en el recinto docente, ya que sería el mejor escaparate y publicidad a Europa y al Mundo, donde demostrar los cambios, mejoras y avances que se habían producido en la sociedad española en aquel comienzo del siglo XX. ${ }^{62}$. Un Laboratorio de ideas políticas- sociales, urbanísticas y arquitectónicas, con la idea de mostrar la innovación creativa y el carácter intelectual que había emergido.

En materia educativa, animo la asimilación de nueva tendencias de conocimiento de la época, sentando las bases de un remozado concepto de Universidad... Un espíritu resulto y ambicioso que pronto habría de tener su traducción en una revolucionaria espacio edificado. El Rey acertó al entender que la expresión arquitectónica era el mejor espejo donde reflejar la rejuvenecida personalidad de España en aquel arranque del siglo XX63.

Las condiciones de docencia en la capital tenían que cambiar. El traslado de la sede de La Universidad de Alcalá a Madrid en 1836, hizo que sus sedes se repartieran y se dispersasen por locales, edificaciones y caserones por todo el casco de la urbe.

${ }^{60}$ Ejemplo de esto sería en 1910, la inauguración de la Residencia de Estudiantes, inicialmente situada en la calle Fortuny y que se trasladó en su lugar actual de la mítica "Colina de los Chopos" Lugar que sería más tarde discutido como uno de los lugares idóneos para localizar la zona universitaria y educativa de la capital, por aquellos que defendían conservar el aspecto rural y natural de la finca de la Moncloa.

61. Palabras de testimonio del decano de la Facultad de Medicina, Sebastián Recasens. cit. En Campos Calvo- Sotelo, Pablo, El viaje de la utopía. Editorial complutense, 2002, p.: 39

62 Ideas concebidas por la gran cantidad de información en la Hemeroteca con noticias y artículos de aquella época donde publicitan la creación de la Ciudad Universitaria como una obra novedosa y colosal por su envergadura y diseño arquitectónico por los mejores técnicos del momento.

${ }^{63}$ Campos Calvo- Sotelo, Pablo, Op. cit. p.39 
Una disposición fragmentada, por las operaciones especulativas del siglo XIX, que dificultaba y ponía en riesgo su eficacia como institución. Además de que las diferentes sedes ocupaban gran parte del suelo de una capital que se estaba reorganizando como ciudad capitalista en una tardía industrialización. Además los edificios eran antiguos e incomparables con los de otros países europeos o americanos, y carecían de factores de diseño que favorecieran el estudio y la enseñanza. No había tampoco un estilo arquitectónico en Madrid específico en cuanto a la Universidad, ni una tipología de aula, esto demostraba el poco desarrollo o investigación hasta el momento respecto a la arquitectura docente. 64 Podemos adelantar, aunque se desarrollará más profundamente y con detenimiento en el segundo capítulo, que la disposición más común de los centros de enseñanza hasta ese momento, se conformaba alrededor de un patio, con un juego de simetrías y de arcadas laterales configurando un espacio, como eran los palacios tradicionales o quizá también los claustro de los monasterios donde había estado siempre la base de la cultura del conocimiento.

Resultaría sencillo enunciar la afirmación de que había una falta de estilo propio de una arquitectura docente en la contemporaneidad de la época, pero quizá sea más preciso relacionar dicha falta clara de tipología previa específica, con la falta de cultura y educación en la población de la época, en España. Si se analizasen más profundamente los datos estadísticos 65 , de este período de tiempo, principios de siglo XX, se apreciarían el alto grado de analfabetismo y por tanto, la falta de público o estudiantes previa que acudiría a esta institución.

- Tasa de analfabetismo: 29\% en 1930 (20\% en hombres y 37\% en mujeres).

- Tasa de analfabetismo en las regiones rurales (Castilla-La Mancha 40\%, Murcia 48\%) y las más urbanas (Madrid 10\% y Cataluña 16\%)

- Variación del producto interior bruto: $-3,87 \%$ de 1929 a $1930,-2,68 \%$ de 1930 a 1931.

- Peso del presupuesto de las administraciones públicas en relación al PIB, en 1930: Gran Bretaña 49\%, Alemania 42\%, Francia 35\%, España 10\%.

Esta falta de educación, cultura y desarrollo institucional, seguramente sería un factor determinante de la inadecuación que la educación universitaria solicitaba. Y esta inadecuación también se hacía presente, igualmente, en los edificios médicos y sanitarios de la época.

\footnotetext{
64 Ver artículo "La génesis urbanística de la Ciudad Universitaria” de Pilar Chías Navarro en el libro, La ciudad Universitaria de Madrid Vol. I. 1998

65 Carreras Albert. Tafunell Xavier. Estadísticas Históricas de España. Siglos XIX-XX. Fundación BBVA. Editorial Nerea, 2005. Véase datos estadísticos de cifras generales extraídos.
} 

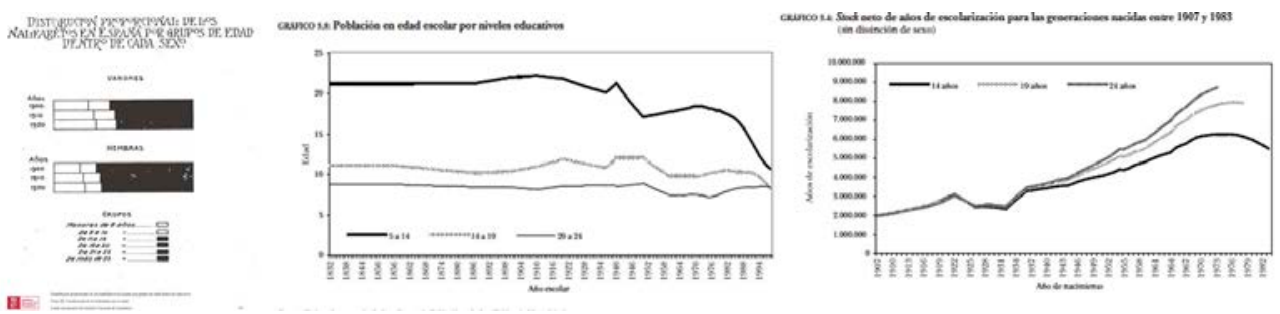

Fig. 9. Datos Estadísticos de Analfabetismo en España proporcional a cada sexo 1920. Stock neto de años de escolarización para las generaciones nacidas entre 1907 y 1983. Fuentes: INE y Estadísticas Históricas de España. Siglos XIX-XX. Fundación BBVA. Editorial Nerea, 2005.

Fig. 10. Censo de Población de 1900. Instrucción elemental por sexo y franja de edad. : INE

La sanidad_A la par de la necesidad de habilitar una zona docente para la gran universidad, era también necesario corregir el déficit de hospitales, equipamientos sanitarios y asistenciales de la capital, que había aumentado por el rápido aumento de población y algunos hechos políticos del momento.

El Hospital San Carlos66, era insuficiente por tamaño, para todas una capital que crecía. Debido a la imposibilidad de ampliación se realizaron a modo de apoyo una serie de edificios temporales o pabellones individuales en el borde o perímetro de la ciudad, los pabellones tipo "Docker" 67 de construcción prefabricada de uso temporal, que se denominó también Pabellones de la Facultad de Medicina por su función docente a la vez que asistencial. Se ubicarían en la llamada zona médica en un emplazamiento que según un informe mandado al ministerio con un plano delimitaba la "zona" que discurría entre el Hotel Parisiana hasta el tiro nacional lindando con el Tiro nacional, el instituto del Cáncer y el asilo de Santa Cristina. ${ }^{6}$ No es de extrañar, por tanto que la zona sanitaria futura, se ubicara en esta zona, ya que como se comprueba en los numerosos planos y parcelarios del momento en aquellos terrenos, se disponían de otros usos de carácter asistencia como asilos, albergues o laboratorios e instituciones benéfico-sanitarios. Estos terrenos serían los escogidos posteriormente para la construcción del actual Hospital San Carlos que formaría parte del equipamiento docente y universitario de la capital.69

66 Ubicado en la calle Atocha denominado Hospital General y de la Pasión durante los siglos XVII y XVIII y "Hospital Provincial de Madrid" en los siglos XIX y XX. Se reformó y se rehabilitó para convertirse en el actual Museo de Arte Reina Sofía.

67 Docker, término anglosajón utilizado para referirse a una instalación a modo de muelle o atraque. Seguramente fueron designados así por su situación en el borde o perímetro de la capital. En concreto se realizaron de manera temporal por el gran número de enfermos a raíz de la Guerra de Marruecos en 1921, como apoyo por la falta de espacio en el Hospital San Carlos.

68 Construcciones previas en la finca, dichas construcciones quedaron representadas en el anteproyecto con los primeros bocetos y tanteos de ordenación y planeamiento por zonas de la Ciudad Universitaria en Octubre de 1928.

${ }^{69}$ Chías Navarro, Pilar. Tesis doctora. "La Ciudad Universitaria de Madrid" Planeamiento y Realización. ETSAM 1983 p. 9 
La doble intención de resolver los problemas sanitarios y docentes fueron los causantes directos de crear el primer núcleo universitario-sanitario en Madrid. Pero también se podría decir que introduce la idea de que España necesitaba una proyección hacia el extranjero, y en esta idea jugaría un importante papel el rey, artífice de la idea. Necesitaba y quería una excusa para ayudar a su pueblo y por qué no, aprovechar para hacer "la obra de su reinado". Una obra que se gestó en 1911; una obra útil, intelectual, necesaria y que fuera a la vez accesible para el pueblo. Y para ello no dudó en invertir parte de sus terrenos para convertir una idea utópica y filantrópica, en un proyecto doblemente real. Un proyecto urbanístico y arquitectónico sin precedentes hasta ese momento.

Esta obra, pase lo que pase, quedará como una prueba de mi amor a España y a su cultura. ${ }^{70}$

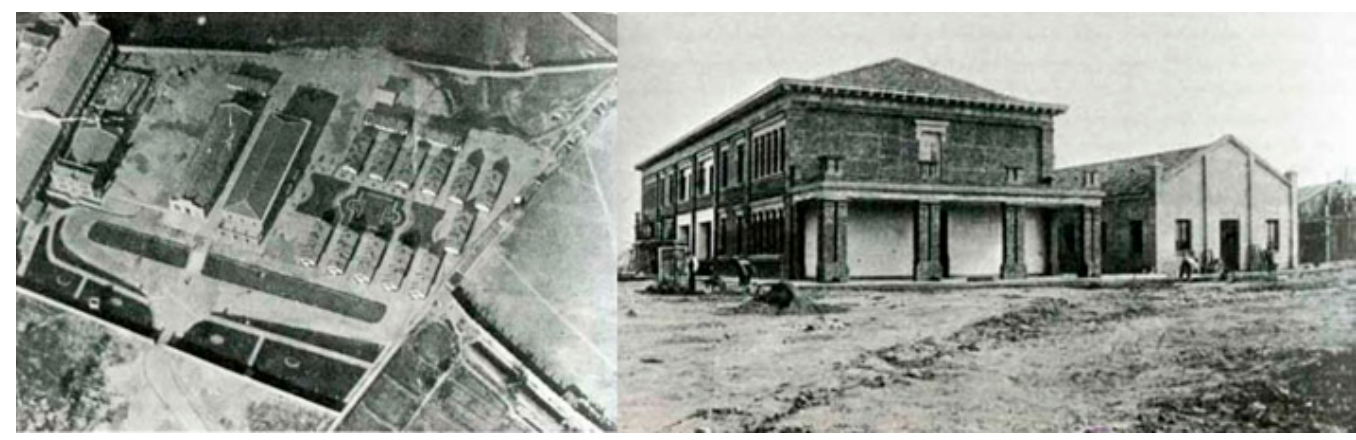

Fig.11 y 12. Fotos Dockers en la Universitaria. Pabellones de la Facultad de Medicina 1929.

Chías Navarro, Pilar. La Ciudad Universitaria de Madrid. Editorial Complutense p. 68

La obra de un reinado _ Según el historiador William Thomas Walsh ${ }^{71}$, era la idea de creación y obra de su reinado como lo había sido siglos antes la ideación y construcción de El Escorial como la obra culmen y recordatoria del rey Felipe II. Ideas de modernización y europeización, ya que existían en algunas capitales europeas, algunos centros o núcleos universitarios nuevos ${ }^{72}$, totalmente opuestos y diferentes a lo que existía en España en aquella época y además era una manera de vincularse y relacionarse con todos los países de habla hispana, creando una "universidad de raza"73 o referencia. Resumiendo, un nodo o vértice, entre las

${ }^{70}$ Alfonso XIII dijo estas palabras durante su discurso en la Universidad de Oxford el 5 de Julio de 1926 al ser investido Doctor "Honoris Causa" por la misma universidad.

71 Williams Thomas Wallsh (1891-1949), historiador inglés centró sus estudios en España como en concreto en la biografía de Isabel la Católica y Felipe II, así como la inquisición española.

72 Muchos de ellos habrían sido visitados por el Rey durante sus viajes por Europa como queda demostrado en los numerosos artículos y noticias sobre los viajes del monarca. Hemeroteca ABC.

73 Termino con que se designó a la universidad, que por la lengua castellana, podía unir a los estudiantes de Latinoamérica y España, recordando la época de la Edad de Oro del Imperio español (incluyendo a Portugal y Brasil). Más tarde dicho término se volvería a utilizar durante el régimen franquista. 
universidades europeas y latinoamericanas, siendo el vértice superior del triángulo, la universidad de Madrid.

El rey Alfonso XIII tenía obsesión de europeizar a su pueblo, y educarlo políticamente para la convivencia democrática, no era fácil ni modesto el empeño y la idea de la Ciudad Universitaria sin duda era un amplio camino, quizá el más seguro para lograrlo. ${ }^{74}$

Es por tanto necesario aclarar, que esta gran iniciativa educativa del Rey, no tiene por qué hacer olvidar otros problemas del momento que se no solucionaron y que se agravaría en la sociedad. Sin embargo, es anecdótico o incluso injusto, que en un proyecto- obra- universidad que iba a llevar su nombre, actualmente tenga solo una pequeña escultura que haga mención y referencia a su labor, a su persona, en todo el recinto universitario. Así también, se demuestra en el artículo escrito por Julio Palacios en la revista Acción Española no 43 en Madrid a fecha del 16 de diciembre de 1933 "Anecdotario para la historia de la Ciudad Universitaria que había de llamarse de Alfonso XIII"

...me preguntó el Soberano si había muchos catedráticos jóvenes en mi Facultad y si no se sentía la necesidad de un cambio completo en la vida estudiantil, no sólo desde el punto de vista docente, sino también en su aspecto social. Añadió que su sueño dorado era construir una universidad nueva, en la que se atendiera tanto a la perfección de la enseñanza como al mejoramiento de las condiciones de vida de los estudiantes, velando por su completa formación intelectual, moral y física. Quería que fuese ésta la obra cumbre de su reinado, gastando en cada Facultad lo que pudiera costar un acorazado. Pero era preciso esperar una ocasión oportuna; había de terminar la guerra de Marruecos y mejorar la situación interior del país. ${ }^{75}$

Según el escritor del artículo, Julio Palacios, el interés del Rey era demostrado y visible, tanto en la Junta de la Ciudad Universitaria, en el Palacio de la Moncloa, del que él era su presidente, como en la cesión de terrenos, propiedad de la corona y en la entrega de un donativo anónimo de un legado que había recibido y que con los intereses ascendía a casi un millón de pesetas. 76

También fué el caso en la Fundación Del Amo, en la que el rey no escatimó ni tiempo ni esfuerzos con Don Gregorio del Amo ${ }^{77}$, de ideas claramente

\footnotetext{
74 Fernández de Sevilla Morales, Miguel. 2009. Op. cit. p.24.

75 Palacios, Julio "Anecdotario para la historia de la Ciudad Universitaria que había de llamarse de Alfonso XIII”, Acción Española, Madrid, 16 de diciembre de 1933. Tomo VIII, número 43 p.634.

76 Palacios, Julio , op cit 634. El donativo fue expedido a nombre del Sr Menéndez de la Patagonia.

77 Médico y diplomático español, fue nombrado cónsul de España en San Francisco, California. Creó la Fundación del Amo, en 1929 para aumentar las relaciones culturales entre España y EEUU. Donó para ello una importante suma en 1929, para realizar uno de los primero edificios de la futura Ciudad Universitaria de Madrid.
} 
republicanas, que estaba en Madrid gracias al Vizconde de Casa Aguilar ${ }^{78}$, ya que conocía su interés en dar un alto donativo a la creación de la Universidad. El resultado de aquel encuentro fue que poco después se inauguraba la primera residencia de estudiantes y uno de los primeros edificio del campus, la Residencia del Amo. Se inauguraría el 12 de Octubre de 1930

No fue sólo el Sr. Del Amo quien sintió entibiados sus sentimientos republicanos ante el entusiasmo con que el Rey quería dotar a España de una universidad modelo...79 Tres días después emprendía D. Alfonso el camino del destierro. Le siguieron los ex ministros vocales de la Junta: Callejo y Yanguas. En el exilio continúan todos, con Guadalhorce y Calvo Sotelo. La Historia ha de hacer justicia y todos tenemos el deber de dar testimonio de cuanto vimos y oímos. ${ }^{80}$

En los años en los que se gestó la idea de la Universidad, se desarrollaron a la vez importantes obras públicas, planes industriales, carreteras, red de paradores y Exposiciones Universales como la de Barcelona o Sevilla. Una época de crecimiento tanto en lo económico, como en espíritu innovador y creativo que se verá más adelante. Sin embargo el pueblo seguía descontento y en parte sus problemas seguían sin resolverse...

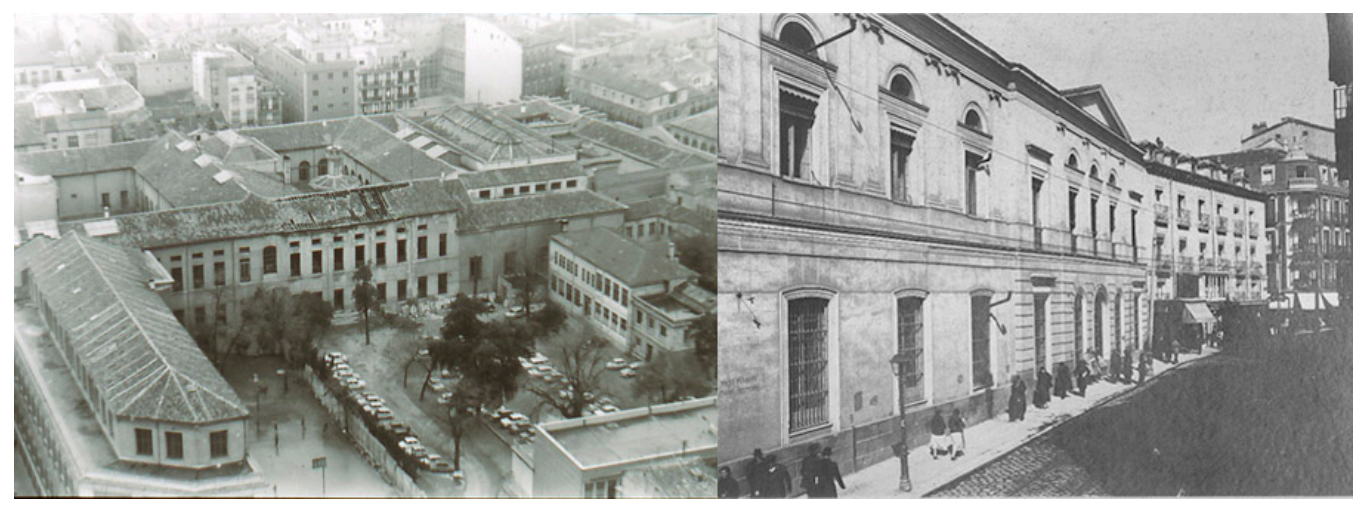

Fig.13. La Universidad de San Bernardo desde el edificio España. 13/12/1968. ARCM. Fondo Fotográfico Martín Santos Yubero. 26166_40. http://open.ieec.uned.es/HussoDigital

Fig.14. Fachada de la Universidad Central calle San Bernardo [1920-1930]". AGUCM SG/1497,01. http://open.ieec.uned.es/HussoDigital

\subsection{2_EL CONFLICTO DEL PRIMER PROYECTO}

La zona de la Moncloa fue el lugar escogido para la implantación del proyecto, pero fue también, y no se puede que olvidar, que no había otro lugar más idóneo por cercanía y accesibilidad a la capital; porque aun siendo un espacio amplio y

\footnotetext{
78 Amigo, médico y dentista del rey Alfonso XIII, fue uno de los principales personajes que influenciarían en el monarca en la concepción de la idea de la nueva universidad.

${ }^{79}$ Palacios, Julio Op cit. p. 635

80 Ibídem p.636 
suficientemente grande como para adecuarse a los cambios y sin el peligro de que las ampliaciones urbanas le dejaran en medio o asfixiado, ${ }^{81}$ su condiciones y belleza paisajística era única en terrenos cercanos a la capital.

Y contando sobretodo el precepto de Alfonso X el Sabio : "De buen aire y de hermosas salidas debe ser la Villa donde quisieran establecer el estudio, porque los maestro que muestren los saberes y los escolares que los aprendan vivan sanos en él, y puedan holgar y recibir placen en la tarde, cuando se levanten cansados del estudio" 82

Sumando la imagen idónea del lugar de la Moncloa, la idea del rey de representar la mejoría de España por medio de la creación arquitectónica de una universidad; el vínculo que se había generado entre el hospital y la docencia, y que en la zona ya existían varios institutos y edificaciones relacionados con estas materias, tras varias órdenes y estudios sobre el emplazamiento e informes de parcelas, comenzó la gestión para la adquisición y expropiación de éstas. Quedando esta idea demostrada en los periódicos y diarios de la época:

La iniciativa del Rey, camino de ser una realidad. Hace unos cuantos años, S.M. el Rey visitó en la Moncloa unos magníficos pabellones que se construyeron para que sirvieran de ampliación a la Facultad de Medicina y que, por necesidades de la campaña de Marruecos, fue preciso utilizar, en unión de unos pabellones Docker, para atender a la curación de soldados heridos y enfermos. Uno de aquellos pabellones es el que actualmente ocupa el Patronato de la Ciudad Universitaria y la oficina técnica adscrita al mismo, encargada de confeccionar el proyecto de la gran urbe universitaria ${ }^{83}$

Es menos conocido, incluso se podría decir que paradójico, que realmente el primero proyecto que se realizó a modo de conjunto ordenador de La Ciudad Universitaria en 1929, quedara prácticamente olvidado. Fue obra de Javier Luque, arquitecto de la Universidad, que realizo un rápido proyecto de la propuesta con un programa de construcciones docentes e instituciones sanitarias anexas, en la zona del Cerro del Pimiento y parte del Tiro Nacional, alrededor del perímetro del Asilo de Santa Cristina. Un proyecto de estilo ecléctico, beaxiano y de plantas clasicistas, muy al gusto de algunos miembros que formarían parte de la Junta futura de la Universidad. ${ }^{84}$ Paradójico es también que el autor, aunque su

81 Como ocurría hasta este momento con otras universidades antes realizadas.

${ }^{82}$ Alfonso X el Sabio en la Ley 2 de su libro "Las Siete partidas" de los estudios en que se aprenden los saberes y de los maestros y de los escolares $i$ ?

${ }^{83}$ Campos Calvo- Sotelo, Pablo La ciudad de la Utopía Editorial Complutense, 2002 p.40

${ }^{84}$ Este proyecto constaba de 14 planos y memoria. Fue entregado al ministerio de Instrucción Pública en Marzo de 1927, siendo olvidado y nunca mencionado ni citado tras la configuración de la Junta de la Universidad, según datos de la Tesis y artículos de Pilar Chías haciendo referencia al "Ensayo de la Facultad de Medicina y de su urbe clínica” en Madrid de 1927 obra del arquitecto realizador del proyecto, Luque 
proyecto no llegara a realizarse, alabara más tarde el proyecto del Paraninfo ${ }^{85}$ de López Otero.

La elección del lugar fue solo el primero de los grandes escollos que se tendrían que resolver. El momento álgido de exaltación popular, sobre todo estudiantil, dio lugar en la prensa a mucho comentarios y pensamientos contrarios; enfocados a veces desde la ideología, desde cómo realizar la reforma de la educación, desde donde colocar el proyecto y como realizar el complejo universitario. ${ }^{86} \mathrm{~A}$ todo esto hay que sumar los problemas de financiación y modo de abaratar la enseñanza. Sin embargo, el problema y la decisión proyectual más importante con que se encontró y se centró la Junta, fue en la elección del lugar.

Varios lugares iniciales se pesaron, aparte de La Moncloa, pero ninguno de ellos fructifió, a pesar de que pudieran haber generado una capital diferente a la que conocemos:

- Alcalá de Henares : la recuperación de Alcalá con una reforma, ya que tenía las infraestructuras básicas y tenía una gran tradición y riqueza patrimonial.87

- El Pardo: esta zona contaba con terrenos estatales, pero la distancia y la falta de urbanización lo hacía inviable.

- TerrenoS periféricos: la utilización de terrenos cercanos a la ciudad, baratos y que facilitaban el problema económico.

El grupo que capitaneaba la idea del Rey, era partidario de La Moncloa, sin atender a la necesidad de expropiaciones o compras para conseguir más terrenos, o el "robo" a la capital de una de las pocas zonas verdes, a modo de pulmón, que quedaban cercanas a la urbe. 88

\footnotetext{
${ }^{85}$ Edificio principal del campus obra de López Otero que quedó en proyecto y que se desarrollara más detalladamente en el estudio y análisis de los Paisajes Prebélicos del capítulo 2

${ }^{86}$ Ideas de la reforma de enseñanza que unían la idea de talleres y técnicas de artes y oficios, muy parecida a las ideas de institutos de tecnología y la escuelas americanas que se trataran más profundamente en el capítulo 2

${ }^{87}$ La idea de Reformar Alcalá como universidad para Madrid no fraguó por la distancia, aunque se retomó este tema tras la Guerra Civil y la reconstrucción de la Ciudad Universitaria años más tarde. ${ }^{88}$ Las grandes zonas verdes eran consideradas el Retiro y la Casa de Campo, ambas de procedencia real. La zona de la Moncloa había empezado a realizar la misma función.
} 


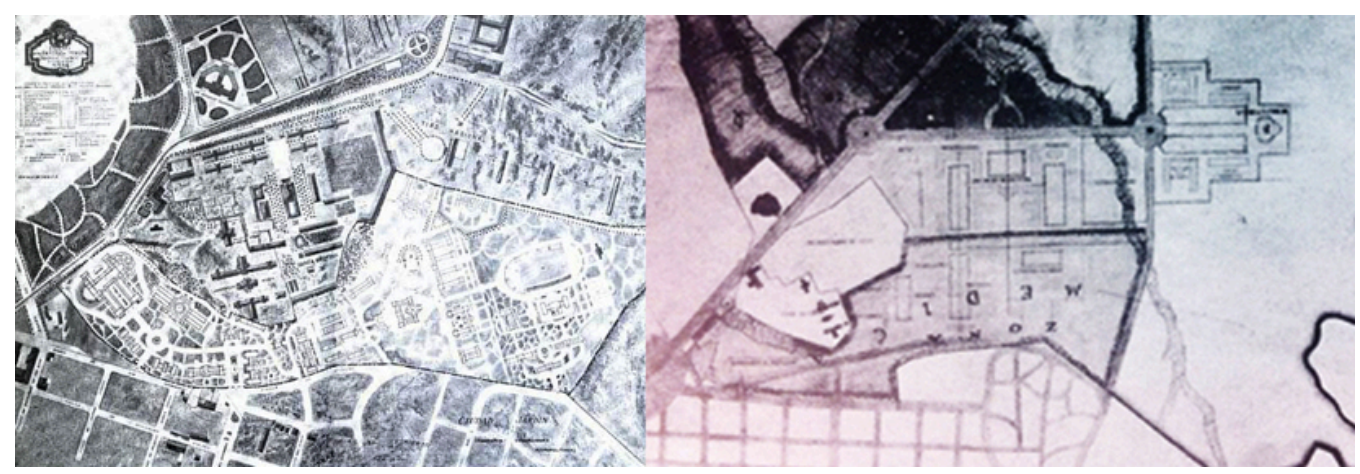

Fig. 15. Proyecto de Javier de Luque. Ensayo dela Facultad de Medicina y de su Urbe Clínica. 1927.

Fig. 16. Anteproyecto de la Ciudad Universitaria. Primeros tanteos de zonificación. Octubre 1928 Chías Navarro, Pilar. La Ciudad Universitaria de Madrid. Editorial Complutense p. 32 y p.80

En 17 de Mayo de 1927, tras ponerse todos los sectores de acuerdo y conseguir la aprobación de una suscripción publica que resolviera los problemas financieros, se dio la aprobación al programa de obras y con ello se constituyó rápidamente una Junta encargada de la gestión, presidida por el rey y miembros de la política, educación e intelectuales del momento, aparte de los técnicos y arquitectos. Un proyecto de tan grandes dimensiones necesitaba de muchos integrantes activos, variedad y suma de ideas. Pero desde el primer momento la postura de dirección unidireccional y autosuficiente quedó marcada en el desarrollo del proyecto. Y así también quedaría marcado en el diseño arquitectónico, urbanístico y ordenado del proyecto en sí.

Sin duda, el Monarca desde aquella fecha acarició en su mente la idea de que se construyera allí una Ciudad Universitaria, y el año pasado, cuando España entera se disponía a rendirle un grandioso homenaje, con motivo de cumplir el XXV aniversario de su coronación, Su Majestad dijo que la más grande alegría y satisfacción que podría proporcionársele, como Rey y como español, sería la de ver que se llevara a cabo la construcción de una Ciudad Universitaria. ${ }^{89}$

${ }^{89}$ Crónica del diario $A B C: 15$ de noviembre de 1928 sobre el inicio de la ideas de crear una universidad en los terrenos de la Moncloa. 


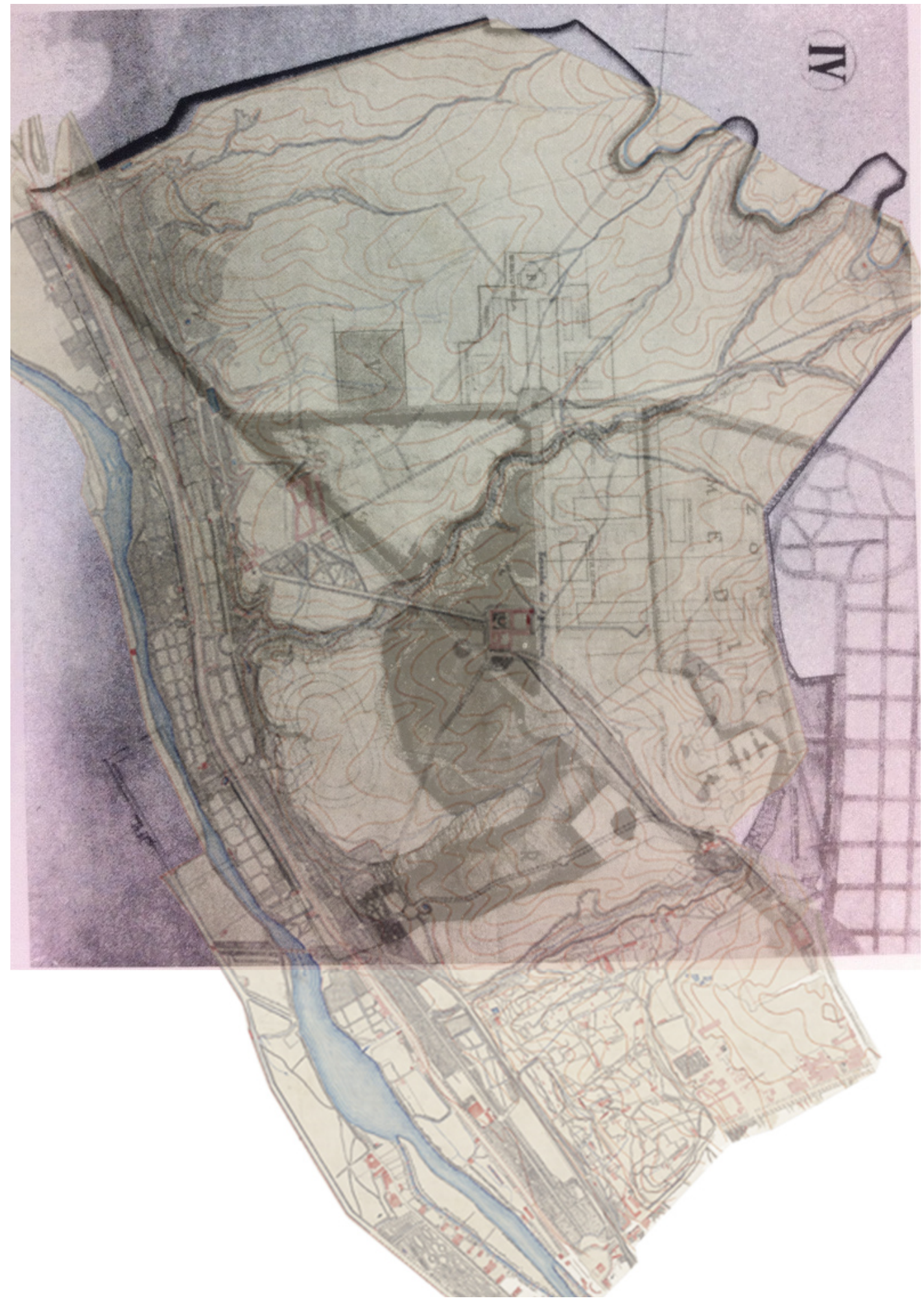

Fig. 17. Superposición primer boceto -Croquis esquema de zonificación y ejes del proyecto universitario sobre Plano de la zona de La Moncloa_(1872-1885) 1/10.000)

Centro geográfico del ejército. Archivo Cartográfico y de estudios Geográficos 


\title{
C.1.4 Reparcelación DE LA CIUDAD UNIVERISTARIA DE MADRID.
}

\author{
p0_Maclas, Límites y Continuidad_ (Unificación)
}

La historia no se desenvuelve solo en el tiempo, también en el espacio. Los sucesos tienen lugar en algún sitio. La historia tiene "escenarios". Hablamos de "lugar de los hechos"9o

Hay lugares, ya estudiados anteriormente, que ni siquiera son merecedores de hacer comentario alguno, a no ser que sea novedoso o innovador. Pero a veces lo nuevo comienza por una explicación que durante mucho tiempo se ha dado por concluida, cerrada o ya agotadamente estudiada, acerca de algo que parecía que ya se ha entendido como obvio, o que ha quedado en el olvido como recuerdo de algo ya pasado y no se puede recuperar.

Tanto en la historia, como en la filosofía el predominio de lo temporal en la narración ha imperado y ha tomado tal poder o derecho, que se acepta sin preguntar. Según el historiador alemán Karl Schlögel, la desaparición del carácter espacial a veces nos llama la atención, pero hay momentos en que quizá el tiempo no abarca lo suficiente de la existencia humana, y es quizá el momento donde el espacio, debe complementar. ¿Qué ocurre cuando se piensa y se describe también en términos espaciales y de procesos variables un lugar o la historia? 0 dicho de otro modo... ¿Se puede explicar la historia de un lugar por los modificaciones meramente espaciales que se generaron en él como un proceso progresivos, sucesivo y cambiable?

Al escribir historia se sigue normalmente el orden del tiempo, la pauta u orden de la historia es cronológico, la secuencia temporal de los acontecimientos. Del mismo modo, se pueden descubrir, acciones, decisiones, componentes de forma, físicos geométricos o conceptuales en las diferencias de dos mapas de un mismo lugar que difieren de fecha, siendo estos correlativos o sucesivos. Estos cambios son procesos de conformación, algunos previos al proyecto, que organizan el subsuelo o lugar físico donde se va a implantar un proyecto trasformador, urbanístico o arquitectónico, pero un proyecto al fin.

Los procesos previos de conformación del lugar, ese germen base donde se realizará el futuro proyecto ( de génesis, de trasformación y conceptual) son los que dieron lugar a los que en este trabajo llamamos ANCESTROS de la Ciudad Universitaria de Madrid.

90 Schlögel, Karl. En el espacio leemos el tiempo: sobre historia de la civilización y geopolítica. Siruela, 2007.p13 
Los mapas del estado del lugar previo al proyecto nos sirven como un recurso auxiliar a modo de adelanto para conocer los condicionantes físicos y que elementos naturales, intocables o condicionantes fijos, condicionaron el proyecto posterior que se realiza.

Es mas tarde cuando la arquitectura y el urbanismo, en los mapas que se analicen mas delante de la investigación con el proyecto inserto, las disciplinas que puedan dar el dato nuevo o innovador que complete y conforme el análisis anterior. Puede quizá que sea el conocimiento del proceso continuo desde el estado previo del lugar su modificación, variación y trasformación sucesiva de trazas, tensiones, continuidades o limites, hasta el momento cuando se decidió la implantación del proyecto urbano de la universidad, lo que nos lleve hasta la idea o estado final del proyecto.

No hay nada que quepa reproducir y replicar cartográficamente: guerra, asedio, huida, rutas de peregrinación, dominios imperiales [...] Pero la mayor ventaja de la representación cartográfica, replica yuxtaposición y simultaneidad, también es patente su limitación: los mapas no dejan de ser estáticos, a lo sumo pueden insinuar movimiento. Los mapas no son replican, construyen y proyectan espacios, y así hacen de espacios territorios por primera vez. ${ }^{91}$
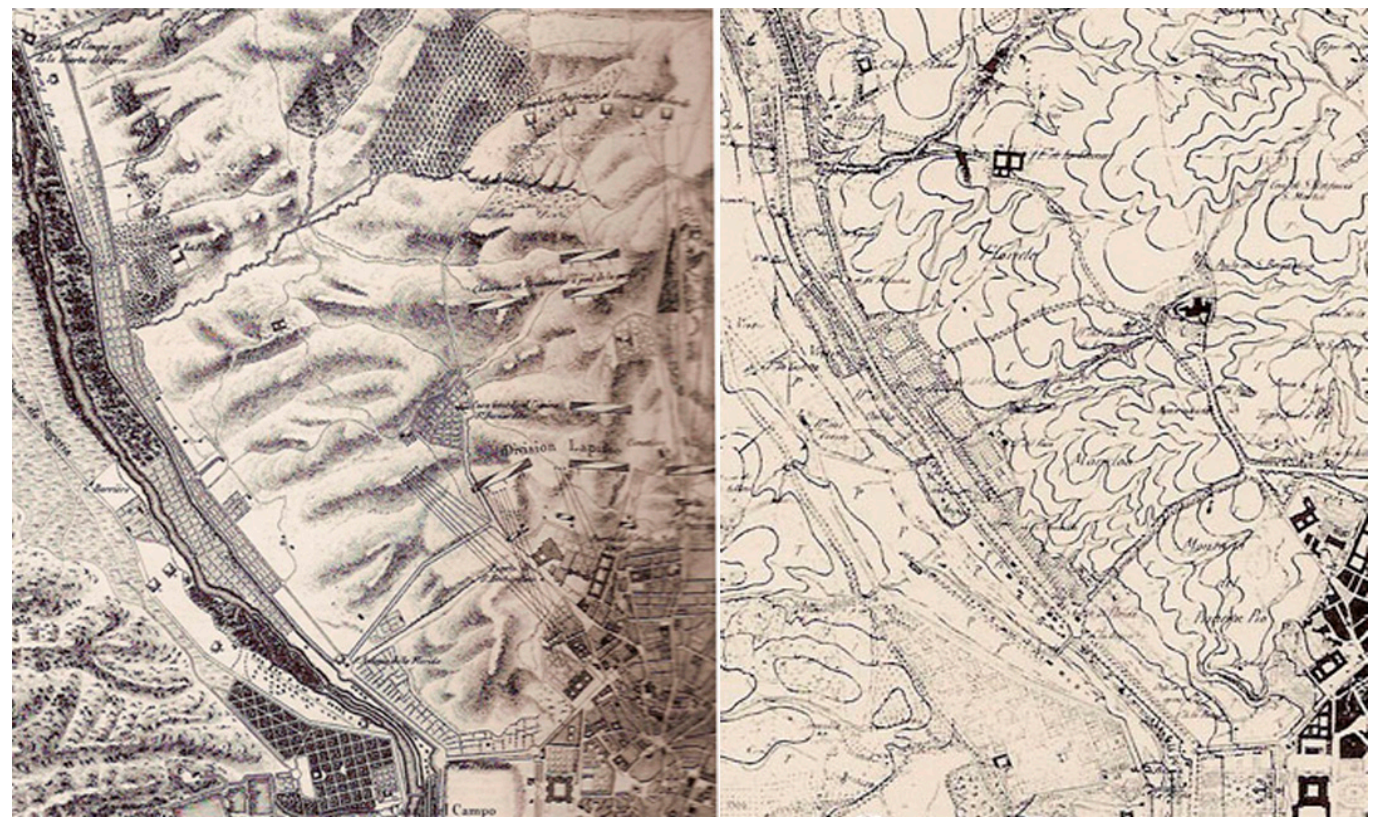

Fig. 18. NODO 1808 Plano de Madrid, Tropas napoleónicas 1/5.000. www.nodo50.org

Fig. 19. Plano de la zona de La Moncloa_(1856) CGE.ACEG

${ }^{91}$ Schlögel, Karl. En el espacio leemos el tiempo: sobre historia de la civilización y geopolítica. Siruela, 2007.p17 


\section{Maclas _ 92}

La actual finca de la Moncloa, en el margen derecho del rio Manzanares, que pasar por el lado oeste de la capital, siempre estuvo vinculada a la realeza. El recinto actual, que alberga el proyecto y obra universitaria mas grande de la capital, se puede interpretar desde su origen primitivo como un ámbito conformado mediante un proceso de anexamiento o maclas de contacto de varios territorios o zonas discontinuos que pertenecían o habían pertenecido a diferentes propiedades, hasta llegar a su configuración final de máxima extensión que hoy conocemos.

Sus orígenes se remontan al siglo XVII, cuando empezaron a delimitarse las propiedades que durante el reinado de Carlos IV, conformarían el Real Sitio de La Florida y La Moncloa93, que se anexionaron sucesivamente conformando el Real sitio:

- La Huerta de la Florida (terrenos al lado del río Manzanares en la parte baja de la llamada Montaña Príncipe Pío) donde se construyó un palacio con zona de jardines que se fue ampliando con huertas adyacentes.

- La Huerta de Fuente El Sol, que tras sucesivos dueños terminaría llamándose de la Moncloa por el conde de Monclova94

- Huerta del Arroyo de Cantarranas al norte, donde se construyó el palacete llamado "Casa Pintada" al lado de huertas y jardines con una cueva a modo de mantequería todo de la misma posesión. ${ }^{95}$ Este palacete sería conocido como "Palacete de Alba, de la Florida o del de la Moncloa"

La unión de estas propiedades dio lugar a la que se conocería y aparecería siempre referenciado en los planos y mapas de la época como Real Sitio de la Florida. ${ }^{96}$ Será en 1807, mediante una nueva macla, en la zona norte, con la adquisición a la Villa de Madrid, cuando se unan a los terrenos y parcelas anteriores, La Villa de Amaniel o la Dehesa la Villa, con lo que el Real Sitio de la Florida conseguiría su máxima extensión ${ }^{97}$. Esta zona de grandes vías de agua que continuarían su curso

\footnotetext{
92Según la R.A.E.: (Del fr. macle).f. Geol. Asociación de dos o más cristales gemelos, orientados simétricamente respecto a un eje o un plano.

${ }^{93}$ Estas extensiones, desde el Palacio Real, junto a la Montaña del Príncipe Pío, hasta el Palacio de El Pardo, permitía al Rey desplazarse de uno a otro sin dejar de pisar sus dominios

94 Esta huerta seria cedida por Godoy incorporándose a la finca anterior.

95 Carlos IV compraría esto terrenos con los de a Florida para conseguir casi la totalidad de la finca

${ }^{96}$ Cercada, vallada y delimitada perimetralmente con diez puertas de acceso.

${ }^{77}$ Datos que se describen en el artículo de "La Recuperación del Palacete. Una intensa Historia", de José Antonio González Cárceles.
} 
atravesando la finca anexa ahora ya unificada, de la Florida ${ }^{98}$, y de la que hay documentación en planos de 1885 sobre la campamentos del Ejercito durante la guerra de África. ${ }^{99}$

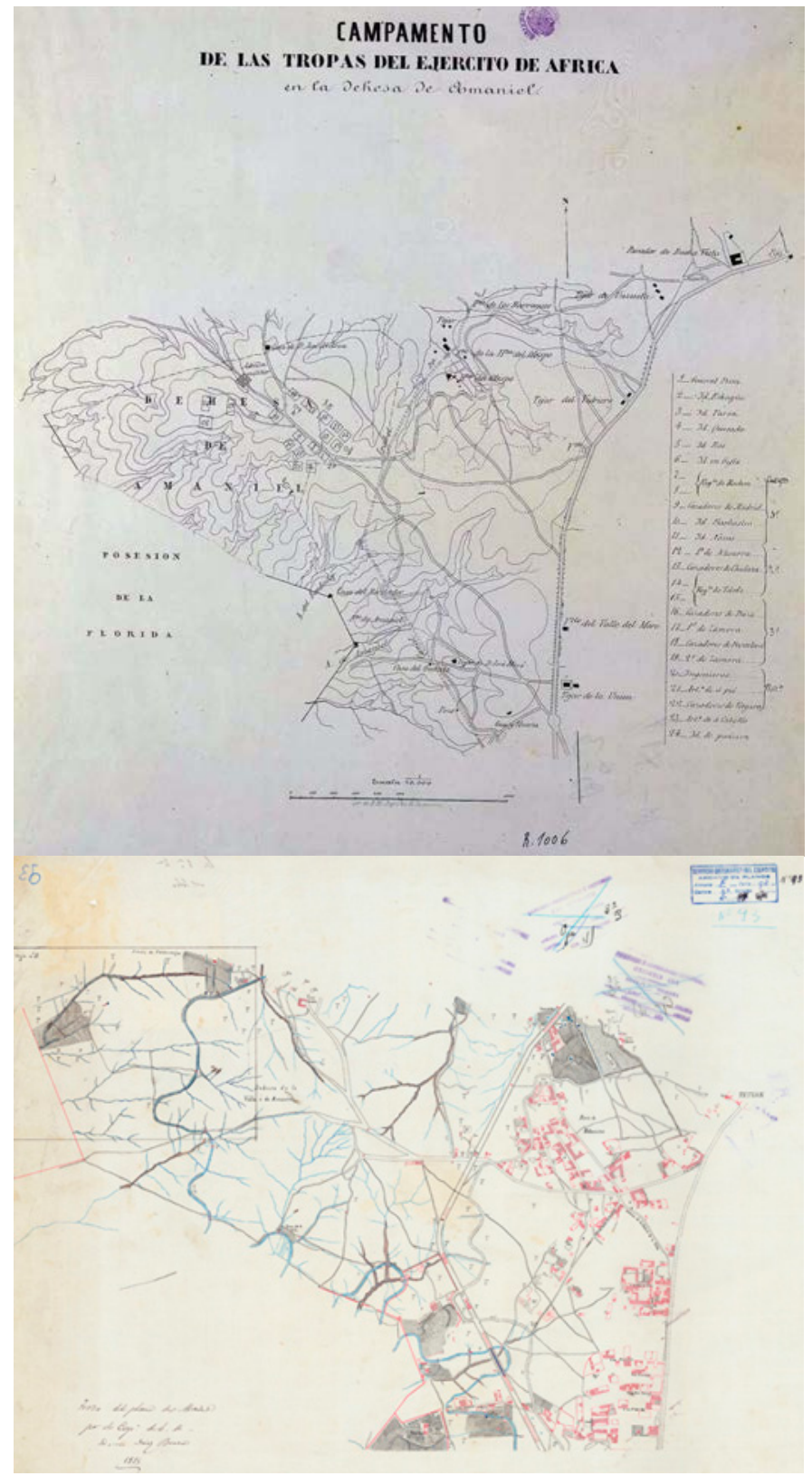

Fig. 20. Plano de Dehesa de Amaniel. Campamentos Militares. Campamento de las Tropas del ejército de África en la Dehesa de Amaniel BNE Biblioteca Nacional Española. Archivo Digital1850-1900

Fig. 21. Plano de la zona de aguas de la Dehesa de Amaniel_ (1885) Centro geográfico del Ejército. Archivo Cartográfico y de estudios Geográficos

98Ver planos adjunto CGE.ACEG 1985 T3.C3-93 Plano de la zona de aguas de la Dehesa de Amaniel_ (1885) y Plano de Dehesa de Amaniel. Campamentos Militares. Campamento de las Tropas del ejército de África en la Dehesa de Amaniel BNE Biblioteca Nacional Española. Archivo Digital 18501900

99 Ver plano adjunto BNE 1850-1900 Plano de Dehesa de Amaniel. Campamentos Militares. 
En 1865, con la llamada «Ley del Rasgo», se aprobó la primera medida que afectaba a las propiedades de la Monarquía, en este caso a las de La Florida y la Moncloa. por la que se permitía la expropiación, segregación de las mismas por parte del Estado y las cargas y responsabilidades recaían en el Rey, como cualquier ciudadano. En 1868, con el termino del reinado de Isabel II, se entrega al Ministerio de Fomento, el sitio de la Florida con el propósito de instalar allí la Escuela Central de Agricultura, siendo este el primer edificio docente que se levantó sobre la fábrica de porcelana de «La China», y comenzó a funcionar con el nombre de Escuela General de Agricultura en 1880; al que sumarían posteriormente las construcciones del Campo de Riegos y la Estación de Ensayo de Máquinas.

Con el proyecto de Urbanización del Extrarradio en 1919 se empieza a plantear las posibles primeras vías que atravesarían esas extensiones periféricas que se habían unido, de la Dehesa la Villa y La Moncloa, cerrando las vías tanto de tranvía como rodadas para delimitar el perímetro, para :

- Reconvertirla en un parque público, por medio de una vía envolvente.

- Destinarla a un parque urbanizable limítrofe entre ciudad y jardín.

Tres años más tarde, en 1923, aparece la primera propuesta, basada en estos criterios más modernos 100 de: tratamiento del terreno y del respeto a la zonificación existente, zona de transición entre lo urbano y lo natural (ciudadjardín), mayor adaptación a la topografía con trazados más orgánicos, e idea incipiente de un posible zona docente-sanitaria como delimitación de la primera "zona Universitaria". Pero lo más importante fue, que a pesar de las numerosas sumas de solares, adquisidores de terrenos y la macla-unión sucesiva de todas ellas con las fincas originales, la zona tendría que funcionar como una zona de transición y bisagra entre la urbe y los usos previos instalados entre la naturaleza y topografía existente.

En 1926, se crea la comisión para la redacción del Plan General de Extensión de Madrid, pero a ella las comisiones no tendrían que ajustarse para la creación del recinto universitario.

Seguramente fue la voluntad del Rey, demostrable por las Reales Ordenes e informes sobre el estudio y la formalización definitiva del lugar de

100 Según la tesis de Pilar Chías (Pag14), con la adopción de soluciones basado en principios más anglosajones, tanto conceptuales como gráficos. 
emplazamiento, lo que ocasionó la adquisición de las ultimas parcelas que se anexionaron, en el interior, llegando hasta las 350Hc finales que configurarían la zona a la que se sumaría el Hotel Parisina, Tiro Nacional, Instituto del Cáncer y algunas propiedades cercanas privadas. Solamente el Asilo de Santa Cristina quedaría como una isla en torno a la que acoplarse el proyecto de trazado de organización. La casa de Labor y el Palacete quedaba lejos y la escuelas de Agrónomos podría y debía ser integrada en el plan urbanizador de la universidad.
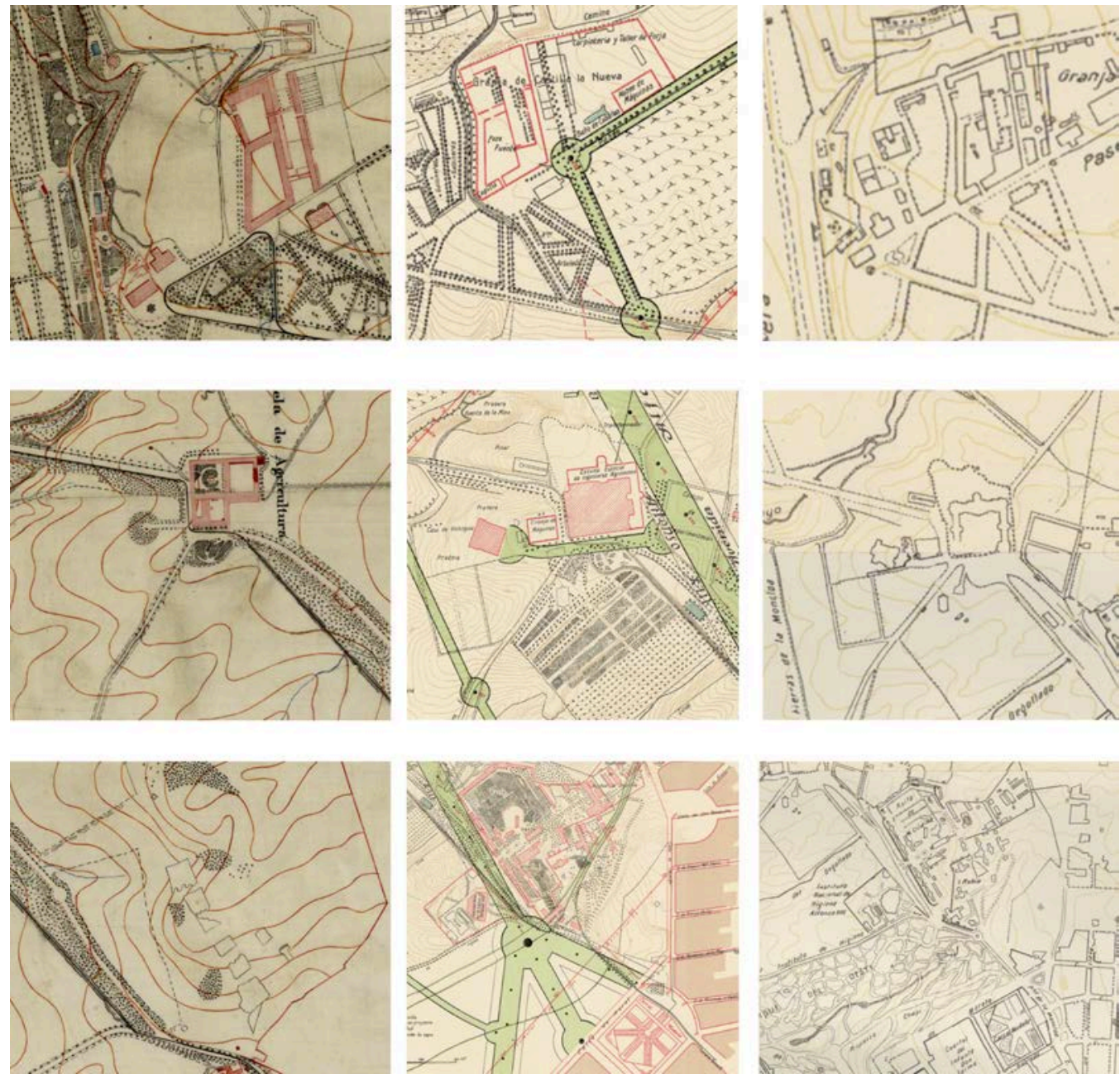

Plano La Moncloa_ (1872-1885) Plano de La Moncloa _ (1927) Plano de población Madrid _ (1929)

Fig.22 Planos comparativa. Zona de la Casa de Labor y Palacete. Zona de terrenos Fábrica de cerámica China "La Fábrica de la China". Zona del Asilo de Santa Cristina y Cárcel Modelo. En el Real Sitio de La Florida. Centro geográfico del ejército. Archivo Cartográfico y de estudios Geográficos 
La facilidad de conectar y unificar - maclas de terreno, parcelas y propiedades,casi todas homogéneas en uso, consiguiendo una extensión mayor y unificada, acción que se realizó desde su origen, y que se intensificó cuando se escogió este ámbito como posible lugar de implantación del proyecto universitario- nos hace suponer que fue uno mas a favor de los puntos clave para ser escogida esta zona como futuro emplazamiento del proyecto que se estaba ideando.

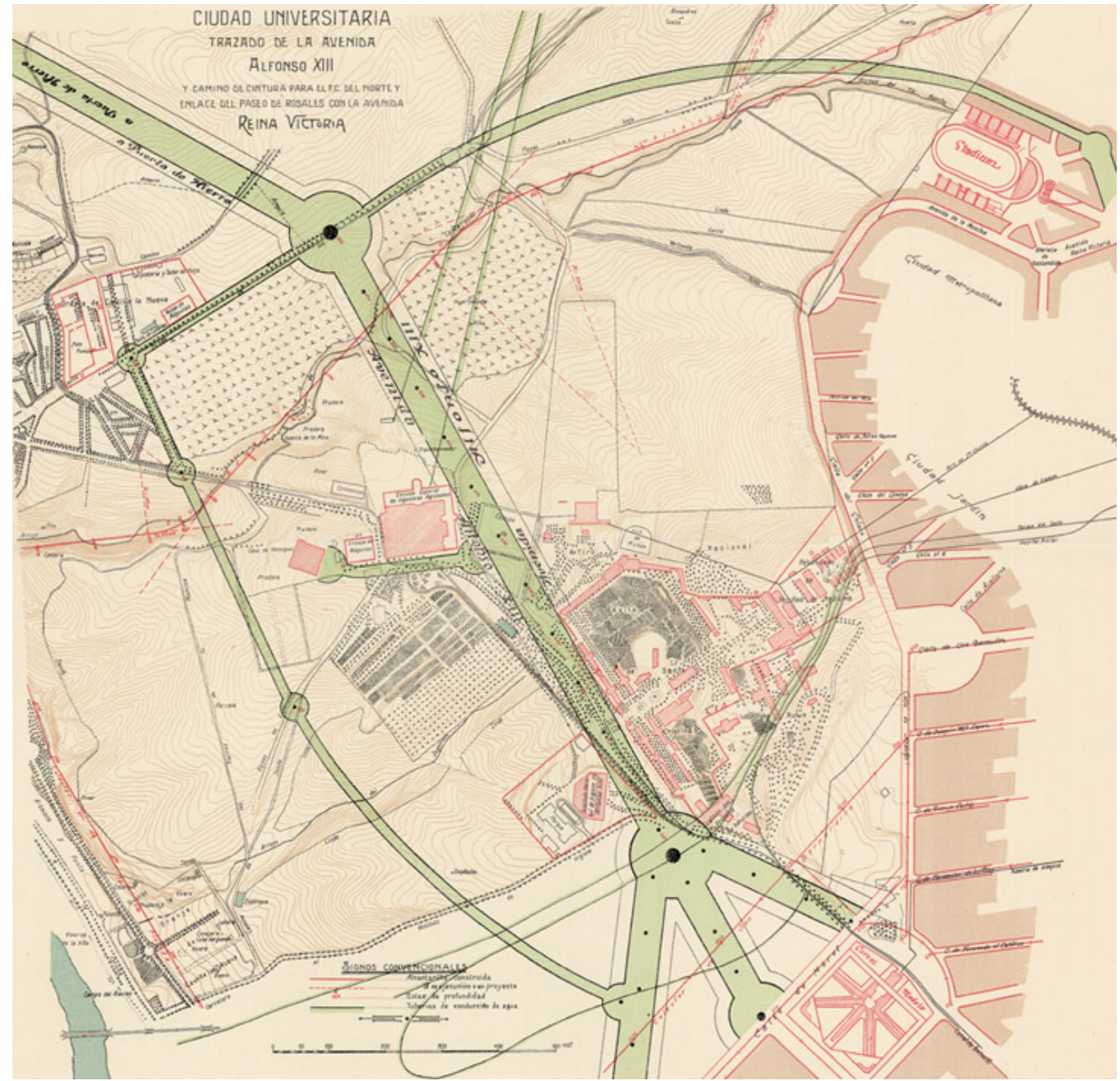

Fig. 23. Plano de la zona viario y conexión de la Plaza de la Moncloa_(1927) 1/10.000

Centro geográfico del ejército. Archivo Cartográfico y de Estudios Geográficos. (CGE.ACEG). 


\section{Límites_ 101}

Los límites del recinto, al igual que los terrenos, fueron alterándose por el sumatorio de parcelas, solares o fracciones de tierras de cultivos, que por medio de cesiones, expropiaciones, permutas o compras conformaron los terrenos iniciales y sus sucesivas ampliaciones. En 1928 se daría por concluida la unificación de todos los terrenos de la finca de La Moncloa con una superficie total de 320-350 Has ${ }^{102}$, desde las 8 Has de parcelas anejas a La Moncloa, hasta llegar a las 35Has de adquisición extra para la construcción de la Universidad.

_Al Norte la finca topaba con La Dehesa de la Villa, destinada a zona urbanizable a modo de la ciudad jardín. Se delimitaba con las tapias de El Pardo y la Puerta de Hierro en una zona de mayor pendiente y más diferencia de cota con respecto al río.

_En la zona sur, se comunicaban los terrenos con la parte desarrollada de la ciudad que llegaba con la parcela de la futura Cárcel-Modelo, la cuña del Barrio de Arguelles 103 , y el Parque del Oeste como zona de antigua escombrera que descendía hacia el rio, llegando hasta el Puente de los Franceses.

_Al este delimitaba con terrenos escarpados, llenos de vaguadas cercanas y comunica con la cercana Dehesa de la Villa, y que iban modificándose según el crecimiento sucesivo de la ciudad, lo que llegarían a ser el futuro Parque Metropolitano y su estado de futbol (continuación de Cuatro Caminos por Reina Victoria) en una de las cornisas de la capital.

_En la zona oeste y de manera casi longitudinal la finca se encontraba delimitada por la orilla del río Manzanares con sus numerosas huertas en el lado más oriental (junto al palacete de la Moncloa) por donde discurría la originaria salida norte de Madrid, la carretera de la Coruña. Se configuraba una estrecha y larga banda encajada entre dos zonas verdes (El Parque del Oeste y El Pardo), creando el límite más largo y continuo a lo largo de la orilla río en su flanco izquierdo.

\footnotetext{
101 Según la R.A.E: (Del lat. limes, -ĭtis). 1. m. Línea real o imaginaria que separa dos terrenos, dos países, dos territorios. 2. m. Fin, término. U. en aposición en casos como dimensiones límite, situación límite.

102 En la tesis, libros o artículos de Pilar Chías se proporciona el dato de $320 \mathrm{Has}$, aunque en otras publicaciones o documentos la cifra varía entre 320-y 350Has.

103 Para conocer más sobre este parte de desarrollo de la ciudad de Madrid, consultar artículo de DIÉGUEZ - PATAO, Sofía "El barrio de Argüelles y la fachada representativa Antonio Bonet Correa (coord.), Urbanismo e Historia urbana en el mundo hispano, IISimposio, Madrid, Universidad Complutense, t. II. 1985
} 


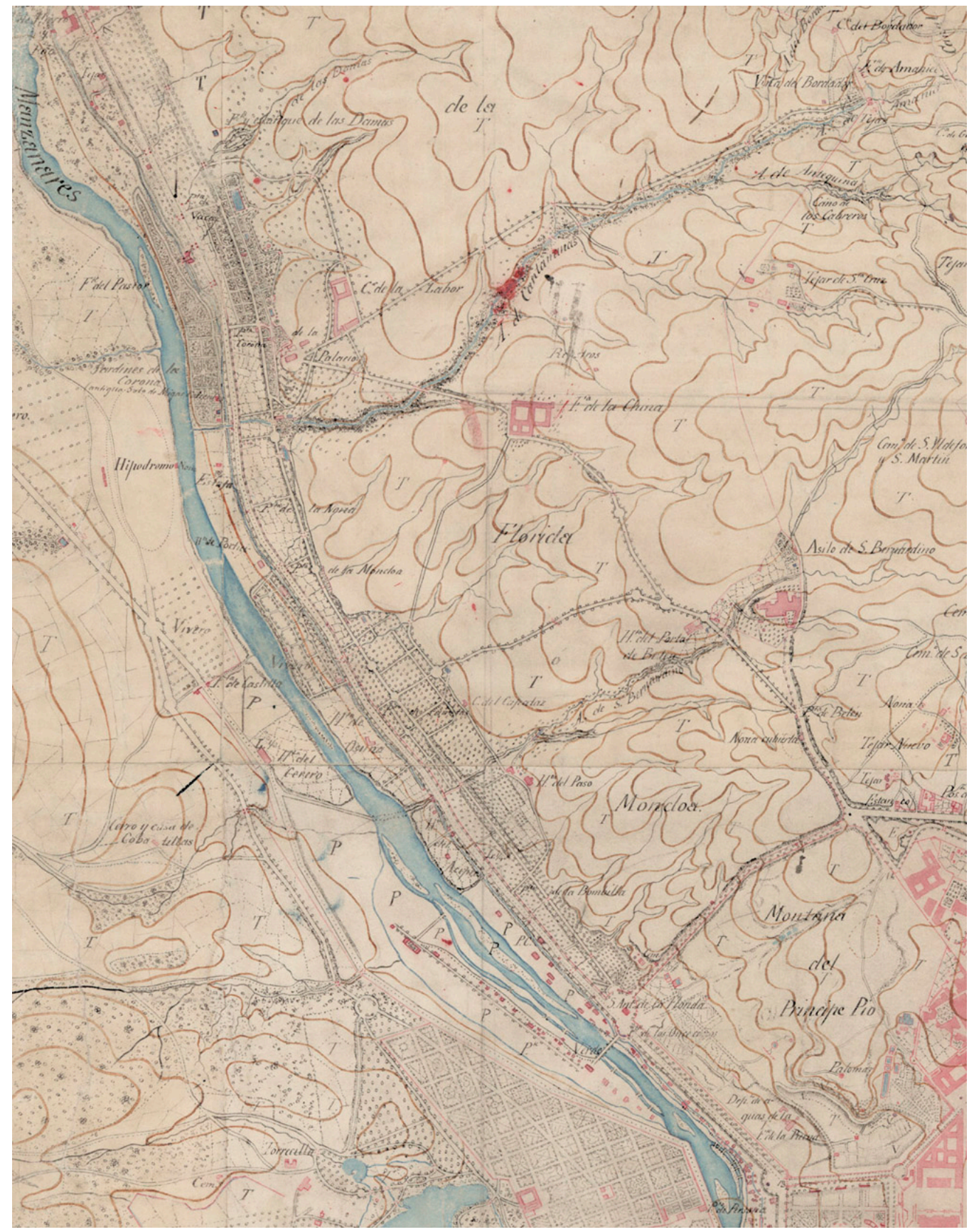

Fig. 24. Plano de la zona de La Moncloa_(1856) CGE.ACEG

Centro geográfico del ejercito. Archivo Cartográfico y de estudios Geográficos

Como aportación valiosa habría que destacar el tratamiento de borde de la finca de la Moncloa, en el que se introdujo el concepto de gradación paulatina en la densidad desde el casco hasta el parque: un planteamiento muy interesante que hubiera debido recordarse en la postguerra. ${ }^{104}$

${ }^{104}$ Chías, Navarro P. La Ciudad Universitaria De Madrid: Génesis Y Realización. Madrid: Editorial de la Universidad Complutense, 1986. P. 168. 


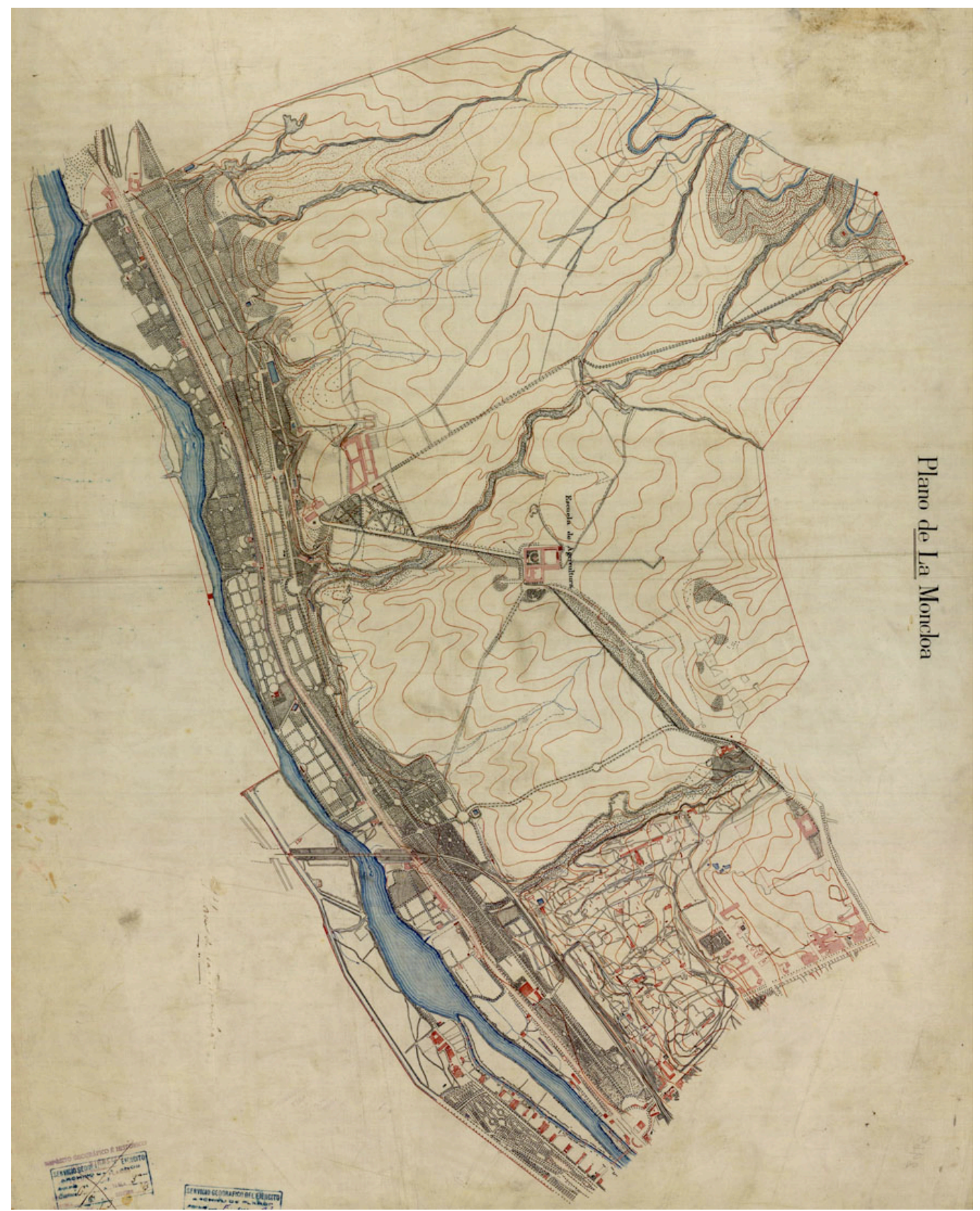

Fig. 25. Plano de la zona de La Moncloa_(1872-1885) 1/10.000)

Centro geográfico del ejército. Archivo Cartográfico y de estudios Geográficos

Realizando un estudio cronológico y continuo desde los planos de mediados del siglo XIX hasta el siglo XX, se comprueba la evolución y la variación en las edificaciones, caminos y viales desde el plano original de 1808 pasado por cartografías de 1856, hasta el plano de 1929.

En 1856 lo más característico de la finca denominada "Finca Real de la Florida" por encima del nombre de "La Moncloa", será el marcado recorrido del Arroyo de Cantarranas que atravesaba la finca de este a oeste, junto con el trazado del Paseo 
de los Almendros, la zona longitudinal de huertas junto al Manzanares y el vial de comunicación en línea quebrada (primero más orgánica para convertirse en lineal) que unía las dos edificaciones de mayor relevancia, la Casa de Labor junto al Palacete y la Fabrica de la China105.

En 1866, con la cesión de la finca al Estado106, los terrenos se hicieron más populares y en 1868 el gobierno ofrece al ministerio de Fomento la finca para instalar allí la Escuela Central del Agricultura que se trasladaría desde Aranjuez (primer huésped docente y futuro universitario de la finca). Este edificio se realizó sobre la fábrica de porcelana "la China", realizándose a su vez una estación de máquinas cercana. Esta escuela que comenzó a funcionar en 1880 contaba con zonas de labranza, huertas, explotación ganadera, talleres y demás dependencias, de ella dependía la Granja de Castilla la Nueva y la casa de Labor ${ }^{107}$.

De las mayores modificaciones que se pueden constatar en planos, debido al desarrollo de la ciudad anexa, fue la incipiente cuña de la ciudad (futuro barrio de Arguelles) donde en el plano de 1885 se representa un inicial Parque del Oeste con sus caminos y su correspondiente Arroyo de San Bernandino. La representación con gran detalle de las líneas de nivel y más el detalle de las zonas de huertas hacen pensar que se trataba todavía de una zona rural y de gran riqueza paisajística sin alterar, pero en la que pronto empezaran a aparecer zonas de descanso, merenderos, asilos y pequeñas construcciones cercanos al acceso a Madrid junto a las construcciones de uso agrario o jardines que ya existían con anterioridad.

Este parque se comenzó en 1893 y quedó inaugurada la primera fase en 1905 (una fase que comprendía una superficie aproximada de 87 hectáreas entre las actuales calles de Moret, y Séneca) realizándose en una zona de abrupto talud y funcionando como zona de transición entre la ciudad y las fincas o solares mas rústicos o naturales. Sus trazados al estilo del jardín inglés paisajista, fue la incorporación de la mejor tradición paisajista internacional ensayada a la trama de un ciudad de Madrid. Destacaba por sus fuertes desniveles adaptándose al terreno, sus caminos sinuosos, praderas, y magníficas vistas sobre la sierra. Así como el uso de elementos a modo de hito como el mirador, la cascada, el lago, el templete de música o los monumentos a los mártires de las guerras coloniales, todos ellos desaparecidos, pero que hacían tener ese carácter paisajístico de recorrido.

\footnotetext{
105 Plano Comparativo 1856

106 Cesión real por Isabel II junto con otras propiedades reales como el Retiro.

107 Será la futura Escuela de Agrónomo, la primera institución y edificación que se instaló en la finca y de ella dependía otras tierras y huertas de alrededor.
} 


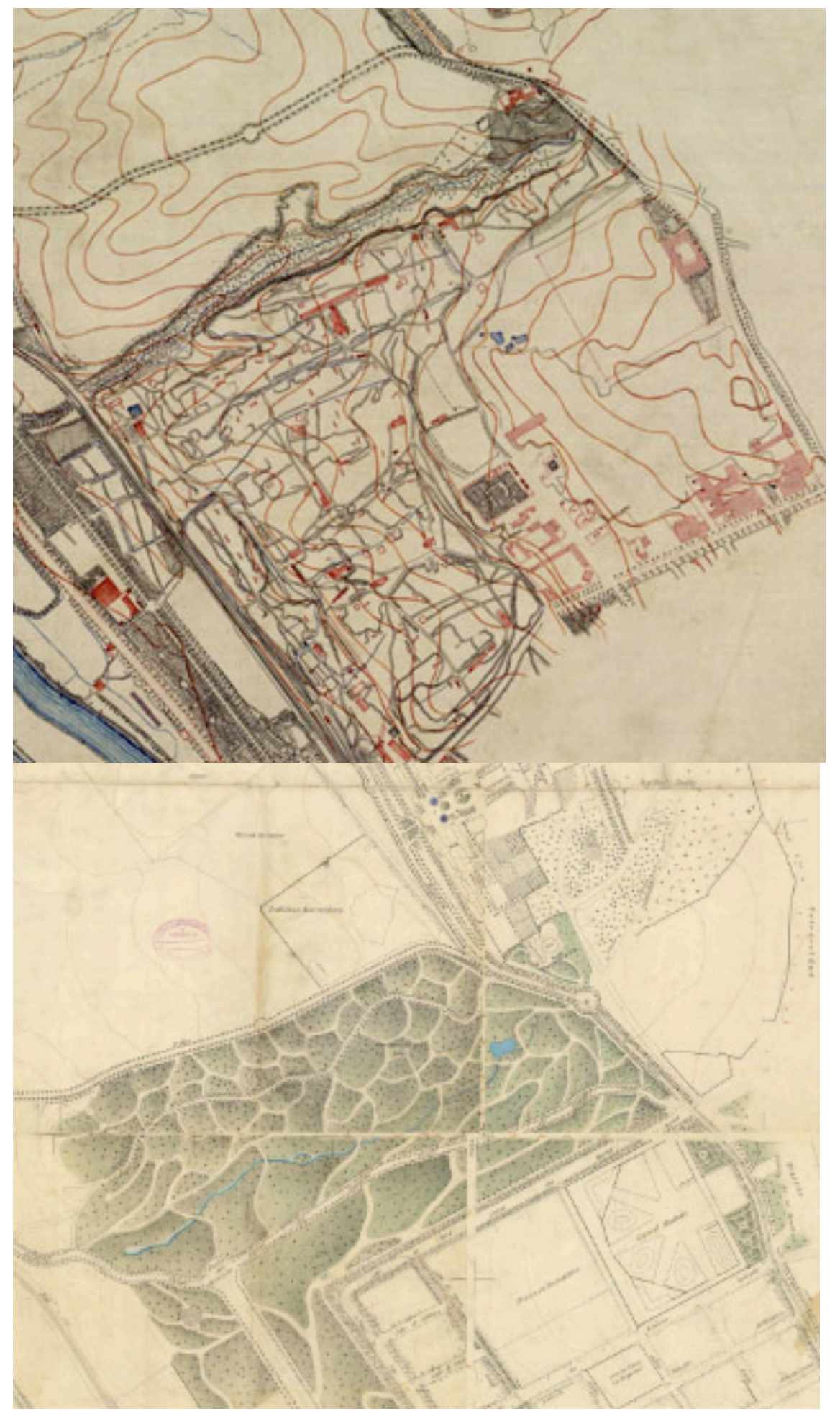

Fig. 26. Comparativa zona Parque del Oeste-Cuña Barrio de Arguelles. Solar de Cárcel Modelo. Plano de la zona de La Moncloa_ (1872-1885) CGE.ACEG Centro geográfico del ejército. Archivo Cartográfico y de estudios Geográficos. Plano Distrito de Palacio 1910 IGN Instituto Geográfico Nacional 


\section{Continuidad.$_{-108}$}

Esta parte de la ciudad, se entendió como un lugar de continuidad, tanto desde el punto de vista de tránsito continuo, como por la concepción global de como las parcelas aisladas previamente, se unificaban formado un terreno y recinto continuo en su extensión. Aquellos que buscaban la unidad, la extensión y la continuidad como elemento básico para la escala y el trazado, valoraron quizá poco la importancia del fragmento como pieza capaz de recomponer de una u otra manera una parte de la ciudad, generándose varias lecturas diversas en el todo continuo.

- Continuidad temporal del recinto, como una sucesión de diferentes momentos de parcelación. Uso la mayoría agrario, de huertas, de cultivo y con la aparición de elementos de índole docente, benéfico-sanitario, lúdico o de recreo.

- Continuidad espacial, por ser la pieza que faltaba, para comunicar la zona de terrenos reales de el Palacio Real y la Casa de Campo, al sur, con la zona mas al norte de el Palacio de El Pardo.

Los terrenos eran accidentados, llenos de desniveles y continúas vías de agua que hacían que a nivel ecológico y paisajístico no hubiera otro igual cerca de la capital. Como se ha visto, por la existencia de numerosas huertas en la orilla oeste, era una zona de gran influenciada por el río Manzanares, que por el discurrir de una profunda vaguada, se inclinaba hacia él, quedando la finca partida por esta gran depresión, que creaba el barranco de Cantarranas. Así mismo si se estudiara la finca por zonas afines, quedaría divida en cuatro partes que formarían uno todo continuo central:

- La orilla del río Manzanares.

- Las vaguada de agua y hondonadas de la zona oeste

- La meseta central donde se suavizaban las vaguadas (zona de las primeras construcciones y explanaciones).

- Las cornisas del este, con la situación predominante de la Colonia Metropolitana en el Cerro de las Balas y los pabellones Dockers en el Cerro del Pimiento. 109

\footnotetext{
108 Según la RAE:(Del lat. continuŭtas, -ātis). 1. f. Unión natural que tienen entre sí las partes del continuo.2. f. Mat. Cualidad o condición de las funciones o transformaciones continuas.

109 Distribución por zonas que sintetiza Pilar Chías en su Tesis. La Ciudad Universitaria de Madrid: Planeamiento y Realización 1983 p. 57
} 
Todos estos terrenos quedaban a su vez atravesados por una línea necesaria de conexión entre Puerta de Hierro y Plaza de la Moncloa que provenía de una más al norte de la zona de El Pardo. Desde 1905, la comunicación entre dichos puntos también se realizaba, por medio de la ampliación que se realizó de la vía del tranvía previo existente, inaugurando la prolongación de la línea 22 que unía Sol con Moncloa (donde se ubicaba la Cárcel Modelo). Discurría paralela a la vía que bordeaba al Parque del Oeste, pasaba por el Instituto de Higiene de Alfonso XII y el Asilo de Santa Cristina hasta llegar a la Escuela de Agrónomos. Fue en 1919 cuando la línea se amplió llegando hasta el Club Puerta de Hierro, configurando la que sería la línea 41, Santo Domingo- Moncloa- Puerta de Hierro ${ }^{110}$. Posteriormente la vía fue modificada con la urbanización y creación del complejo universitario.

Era por tanto una zona de topografía ondulada, fraccionada y movida, que contenía edificios previos, pero cuya conexión o comunicación era la base organizadora y formal, adaptándose al terreno, por medio de los viales rodados y el tranvía. Dichos medios de comunicación y continuidad en la parcela atravesaban el recinto creando una vía que servía a la vez como bisagra y conexión con la ciudad.

En 1910 con el Proyecto de Urbanización del Extrarradio111, se propuso una línea formando una ronda circular entre Sol- Cuatro Caminos- La escuela de Agricultura-, cerrando el anillo con la otra zona de Cuatro Caminos-Asilo de Santa de la Paloma- Escuela de Agricultura, ronda o vía de circunvalación a la que se llamó Paseo de Ronda. Fue duramente criticado y la propuesta en 1922 del Plan General de Extensión se originó en parte por este, aunque la nueva propuesta se diferenció poco del anterior, tuvo en cuenta un poco más la topografía y la orografía del lugar.

Es justo en esta época, en los primeroS años del siglo XX, cuando observando el plano parcelario de 1910 denominado "Distrito Palacio"112 aparecen nuevas edificaciones, viales y parcelas, algunas ya con nombres y designaciones específicas. El Paseo de La Moncloa comunica el Palacete y la Casa de Labor con la renombrada Escuela de Agricultura de Alfonso XII, llegando hasta la Cárcel Modelo en el borde de la ciudad frente al Parque del Oeste (estando delimitado el perímetro y diseñado todos sus caminos y trazados internos). A ambos lados

\footnotetext{
110 Datos extraídos de la documentación de la Exposición Temporal "De Moncloa a Puerta de Hierro hacia una exposición permanente de la Ciudad Universitaria de Madrid realizada por el Consorcio en colaboración con la ETSAM en 2007.

111 El proyecto realizado por Núñez Grañez definía más las líneas de comunicación y viarios, definiendo a los futuros terrenos de la Ciudad Universitaria como Parque Público.

112 Plano Comparativo 1910. 
aparece el Asilo de Santa Cristina y la Parisina y se delimitan las parcelas del Instituto Rubio, del Instituto Antirrábico y la zona del Tiro Nacional113. Dos caminos aparecen al norte de la finca "El camino de la Almendros" y el "Camino alto de la Casa de Labor" ambos con un trazado claro de cerrar y comunicar esta zona con el norte de la capital que ya estaba creciendo de acuerdo a la previsión de su desarrollo.

Pequeñas construcciones entre parcelas nuevas muchas de ellas denominadas como tierras de labor o cultivo de viñedos rellenan y colmatan la finca, con la zona de las huertas junto al Palacete y el Río aunque con menos extensión en anchura y menos significación en el plano. Una finca real que había comunicado las zonas verdes de procedencia real como la Casa de Campo o la Finca del Pardo, y en la que ninguna de las propuestas de planeamiento le había afectado hasta entonces por su carácter agrario y natural.

Con el plan de 1922, el Plan General de Extensión, se concretaba algunos detalles en la zona de La Moncloa: La transición parque-casco urbano con viviendas, una adaptación a la topografía por medio de trazos más orgánicos y una zona universitaria, anexa donde ya existían espacios sanitarios ${ }^{114}$.En 1926 se creó la definitiva comisión que realizaría el Plan General de Extensión de Madrid; pero hasta que no apareció el proyecto de la Ciudad Universitaria entre 1919 y 1927 no se realizaría urbana y de manera definitiva la ordenación de esta finca, apareciendo dos comisiones, siempre proyectando el hospital y los servicios sanitarios junto a la facultad o universidad anexa..

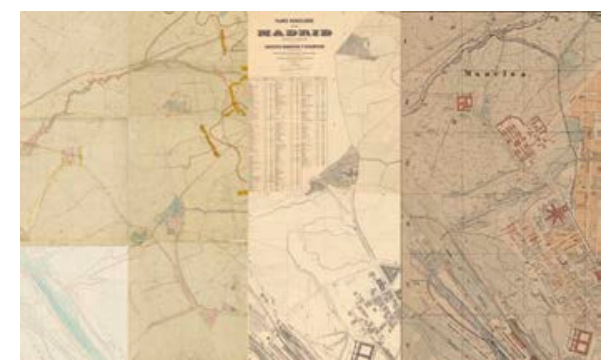

Fig. 27. Plano Catastral 18701.200 Kilométricas Instituto Geográfico Nacional. IGN - Parcelario Urbano López Ibero 1874/1875 Instituto Geográfico Nacional IGN. Plano de Madrid y sus contornos_(1877) 1/10.000 Centro geográfico del ejército. Archivo Cartográfico y de estudios Geográficos

\footnotetext{
113 Importante es reseñar y nombrar estas edificaciones y parcelas, ya que serán objeto de reparcelaciones, expropiación y modificaciones, tanto en el proceso de proyecto y construcción de la Ciudad Universitaria, como durante los tres años de la guerra civil.

114 Estos espacios sanitarios eran los antiguos Pabellones Dockers, el Instituto Rubio y el Instituto Alfonso XIII, renombrando posteriormente con el nombre de Instituto Antirrábico durante la época de la Republica.
} 


\section{Planos S. XIX (1808-1886)_}

BNE Biblioteca Nacional Española. Archivo Digital./IGN Instituto Geográfico Nacional. CGE.ACEG. Centro Geográfico del Ejército y Archivo Cartográfico y de Estudios Geográficos. IHCM. Instituto de Historia Y Cultura Militar /Archivo General Militar del Madrid. Cartoteca

*BNE 1850-1900

Plano de Dehesa de Amaniel. Campamentos Militares. (parcial) Campamento de las Tropas del ejercito de África en la Dehesa de Amaniel BNE Biblioteca Nacional Española. Archivo Digital

\section{*CGE.ACEG 1885}

Plano de la zona de aguas de la Dehesa de Amaniel_ (1885) (parcial)

Centro geográfico del ejercito. Archivo Cartográfico y de estudios Geográficos

NODO 1808

Plano de Madrid, Tropas napoleónicas 1/5.000

http://www.nodo50.org

BNE 1849

Plano de Madrid, grabado bajo la dirección de Juan Noguera, 1849_ (1849) Ultramar 1/5.000 BNE Biblioteca Nacional Española. Archivo Digital

\section{CGE.ACEG 1856}

Plano de la zona de La Moncloa_ (1877) 61(5)

Centro geográfico del ejercito. Archivo Cartográfico y de estudios Geográficos

\section{BNE 1857-1861}

Ensanche de Madrid : anteproyecto, 1857-1861_(1857) 1/2500

BNE Biblioteca Nacional Española. Archivo Digital

BNE 1870-1879

Madrid y medios de defensa,_(1870-79) 1/20.000

BNE Biblioteca Nacional Española. Archivo Digital

BNE 1866

Plano de Madrid ,_(1866) 1/20.000

BNE Biblioteca Nacional Española. Archivo Digital

BNE 1879

Plano de Madrid -publicado por D. José Pilar Morales

Pedro Peñas y Otto Neussel Litografía_ (1879) 1/10.000

BNE Biblioteca Nacional Española. Archivo Digital

BNE1883

Plano de Madrid por D. Emilio Valverde, 1883_(1883) 1/10.000

BNE Biblioteca Nacional Española. Archivo Digital

IHCM 1885

Plano de Madrid_(1885) 1/10.000

D. José Pilar Morales (ingeniero) y D. Enrique Sánchez y Rodríguez (Arquitecto)

Archivos General Militar de Madrid

\section{IHCM 1886}

Plano de Madrid por el Instituto Geográfico y Estadístico_(1886) 1/10.000

D. Benito Martínez y D. José Méndez (topógrafos)

Archivos General Militar de Madrid 
IGN Catastral-Kilométrica 1860

Plano Distrito de Palacio

IGN Instituto Geográfico Nacional

IHCM 1872-1885

Planos Cartográfico 1872-1885

Centro geográfico del ejercito.

Archivo Cartográfico y de estudios Geográficos

IGN 1874/1875

Parcelario Urbano López Ibero

Instituto Geográfico Nacional

IHCM 1877

Plano Cartográfico 1877

Centro geográfico del ejercito.

Archivo Cartográfico y de estudios Geográficos

BNE Real Posesión de la Florida.

Reducción del Plano Levantado por la Direc. Gral. de Operaciones Geográficas.

Centro geográfico del ejercito. Archivo Cartográfico y de estudios Geográficos

\section{Planos S. XX (1900-1929)}

BNE Biblioteca Nacional Española. Archivo Digital.. IGN Instituto Geográfico Nacional. CGE.ACEG. Centro Geográfico del Ejército y Archivo Cartográfico y de Estudios Geográficos

BNE 1900

Plano hojas no 1 y no 3 de la plano de Facundo Cañada López.

Plano de Madrid y pueblos Colindantes

Biblioteca Tomás Navarro Tomás (CCHS-CSIC) (Fuente Original)

BNE Biblioteca Nacional Española. Archivo Digital

IGN 1910

Plano Distrito de Palacio

IGN Instituto Geográfico Nacional

CGE.ACEG 1927

Plano de la zona viario y conexión de la Plaza de la Moncloa_ (1927)

Centro geográfico del ejército. Archivo Cartográfico y de estudios Geográficos

CGE.ACEG 1929

Plano de población Madrid_ (1929)

Centro geográfico del ejército. Archivo Cartográfico y de estudios Geográficos

IGN 1929

Plano Parcelario 1/2000

IGN Instituto Geográfico Nacional 


\section{NOTA EXPLICATIVA}

Se ha considerado necesario estudiar las preexistencias del lugar de su implantación como sustrato base donde se desarrolló todo el proyecto generador del recinto universitario. Esta tesis se centra en los siguientes capítulos a los primeros treinta años de un proyecto y sus procesos de conformación (Génesis/ Trasformación y Distorsión) Un periodo de casi tres décadas desde 1926, hasta el final de los años 60,dejando un camino o puerta abierta para otro estudio continuado y secuencial donde se termina este trabajo, que serían los siguientes 50 años hasta la actualidad. 


\section{CONCLUSIONES DE LUGAR / Espacio-Tiempo.}

- Su localización y conectividad, y no su heterogeneidad paisajística o topográfica, fue lo que originó que se escogiera este lugar para la implantación del proyecto universitario docente de la capital.

- Las numerosas parcelas de uso agrario y alguna edificación preexisten, no impidieron su unificación y anexión con límites rectilíneos y artificiales.

- De las preexistencias, durante la reparcelación, sólo se mantuvo algunos edificios "intocables" y el vial de comunicación principal, como articulación diagonal de salida. Fueron los condicionantes que organizaron su desarrollo en dos zonas

- El lugar pierde su identidad de espacio natural al introducir el eje en la articulación central como columna del programa universitario y otras parte orgánica junto al río. Desaparecen los elementos naturales centrales (la meseta, solares y cultivos) al igual que perjudica y oprime la zonas mas periféricas (de vaguadas, canales de agua), que terminarán también modificándose con posterioridad.

- Los vacíos, desmontes e infraestructuras alteraron completamente el terreno y orografía inicial, pero se realizaron posteriormente (tras el conflicto bélico); cambios mucho mayores y con peores consecuencias, considerados la mayoría de ellos necesarios en su momento de ejecución por los intereses del momento, pero pocos positivos o favorables para el desarrollo positivo del lugar.

- Lo anteriormente indicado fue un condicionante que tuvo que salvarse con una gran modificación del terreno, cotas y rasantes, (ya que se prefería un lugar a igual cota) se convierte en el mejor valor para los procesos de proyecto de trasformación y posterior de distorsión, aunque ya en un estado modificado.

- La ciudad quedaría, tras la realización del proyecto, como gran cornisa posterior a modo de fachada de fondo tras un espacio verde de transición a modo de "cinturón-colchón" o zona de filtro, independizando mas si cabe a la universidad de la urbe que solo se comunicaría por la vía de acceso a la capital.

- El lugar, entendido como suelo independiente y anexo que sustenta el proyecto universitario, se ha modificado en igual grado o magnitud, a como se ha desarrollado la universidad a través de los procesos proyectuales en los diferentes periodos espacio temporales. Cada uno con diferente grado e intención, de unificación o funcionalidad, de necesidad de protección y estratégico o de perspectiva y limpieza.

- La independencia, insularidad y conformación como isla separada de la ciudad, generó (y continúa) problemas de comunicación y desarrollo, pero ha facilitado un marco físico con una legibilidad de identidad propia y sentido de ciudad anexa a otra pero de características diferentes. 


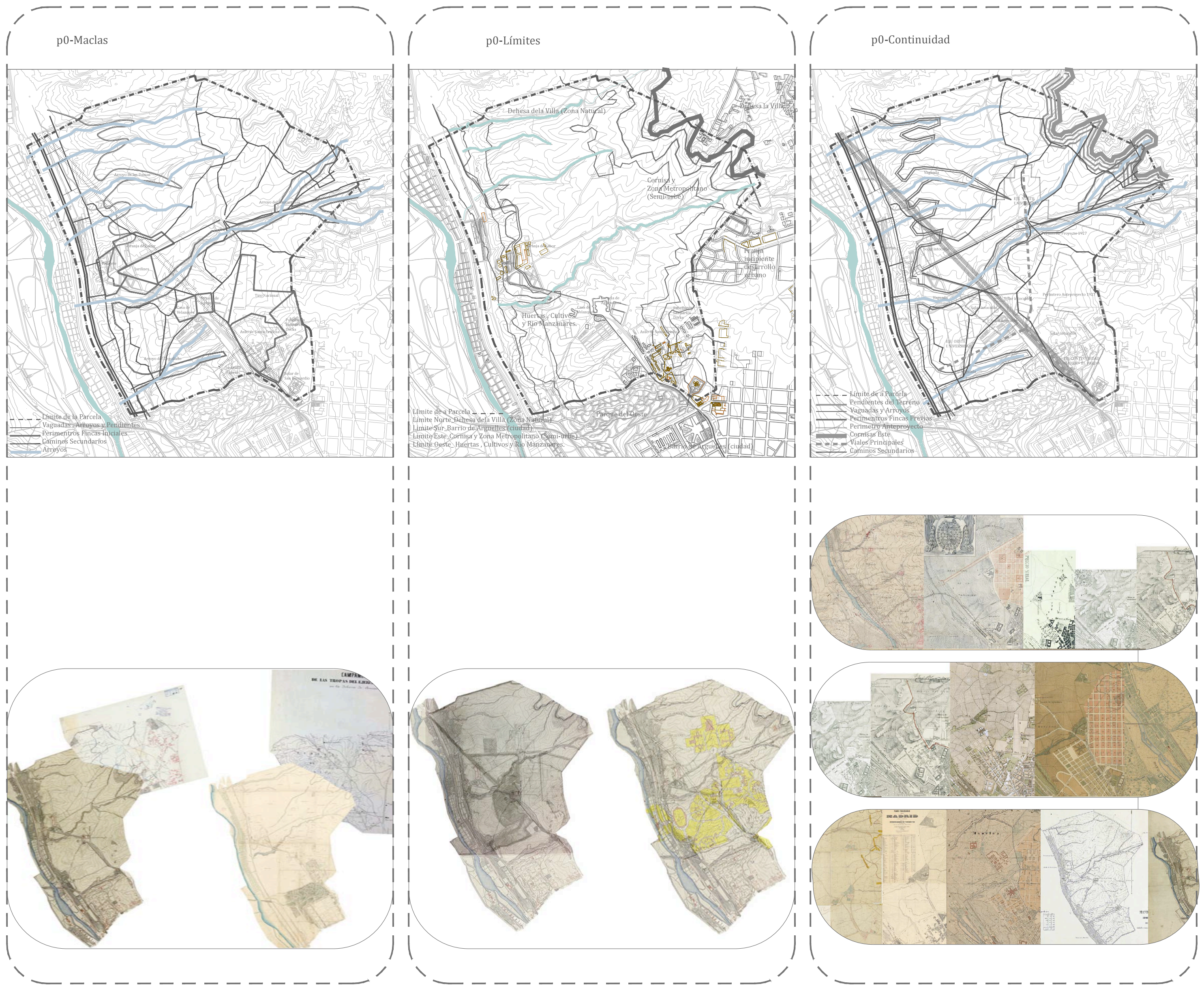

La Reparcelación de la CUM p0-Maclas
p0-Límites
Continuidad

La MACLA es el proceso por el cual se realiza la agrupación simétrica de Se llaman «de contacto» Se llaman «de contacto» unen en un plano, $y$ «de compenetración»si estáncruzados y
e compenetrados entre sí.

p.0 real o imaginaria, frontera que separa dos cosas. Se pude enntender como el fin, el grado extension. Es el término o extremo superficial de algunas cosas.

La CONTINUIDAD 0 definie desde vista territorial punto de vista teritocial, espacial
o proyectual como la circunstancia de suceder o hacerse algo sin estaps ss a union o interrupcion entre las partes que forman un todo que se desarrolla en el tiempo.

La Ciudad Universitaria de Madrid Año 1808-1929 Escala 1:30.000 


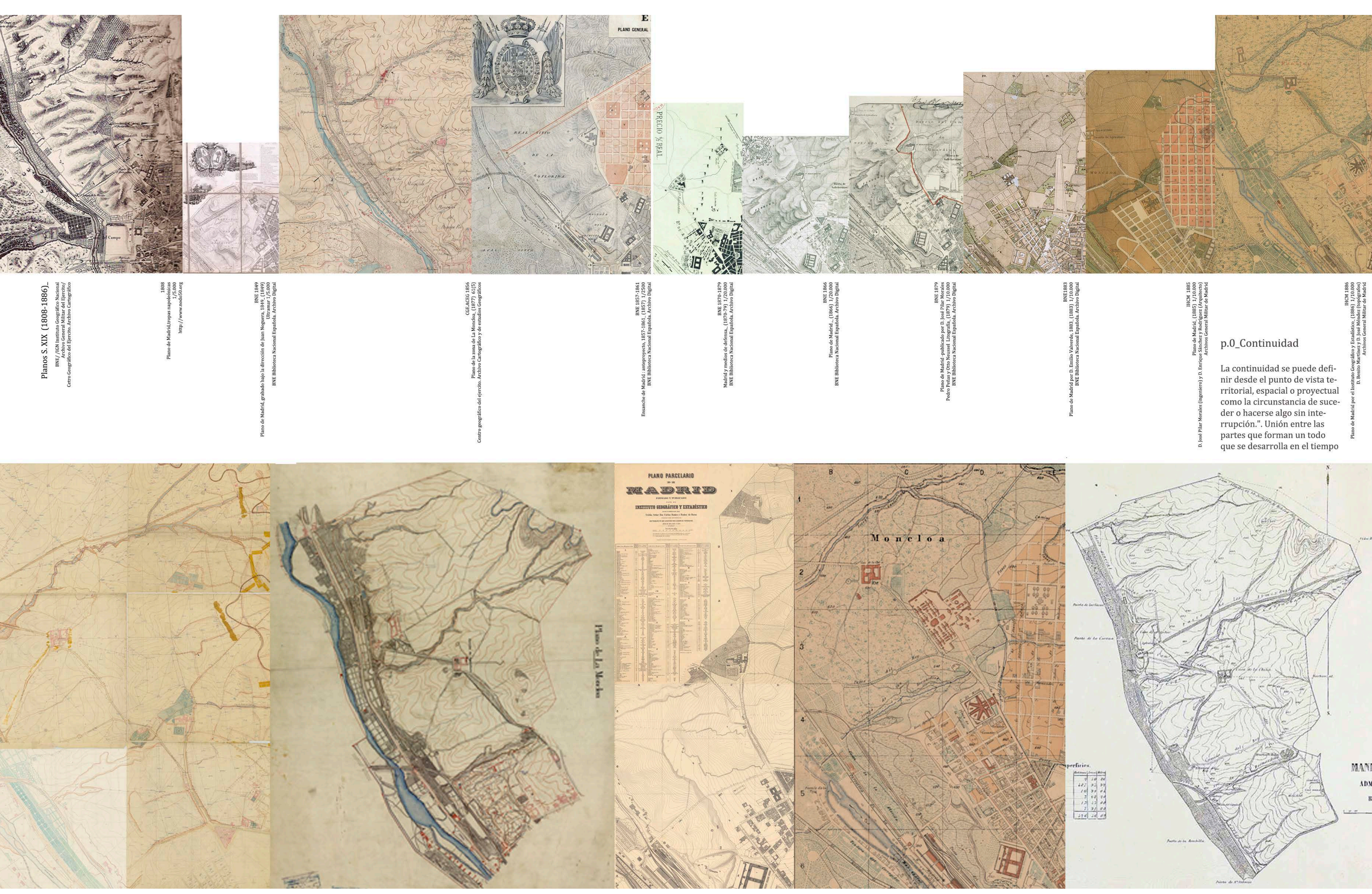



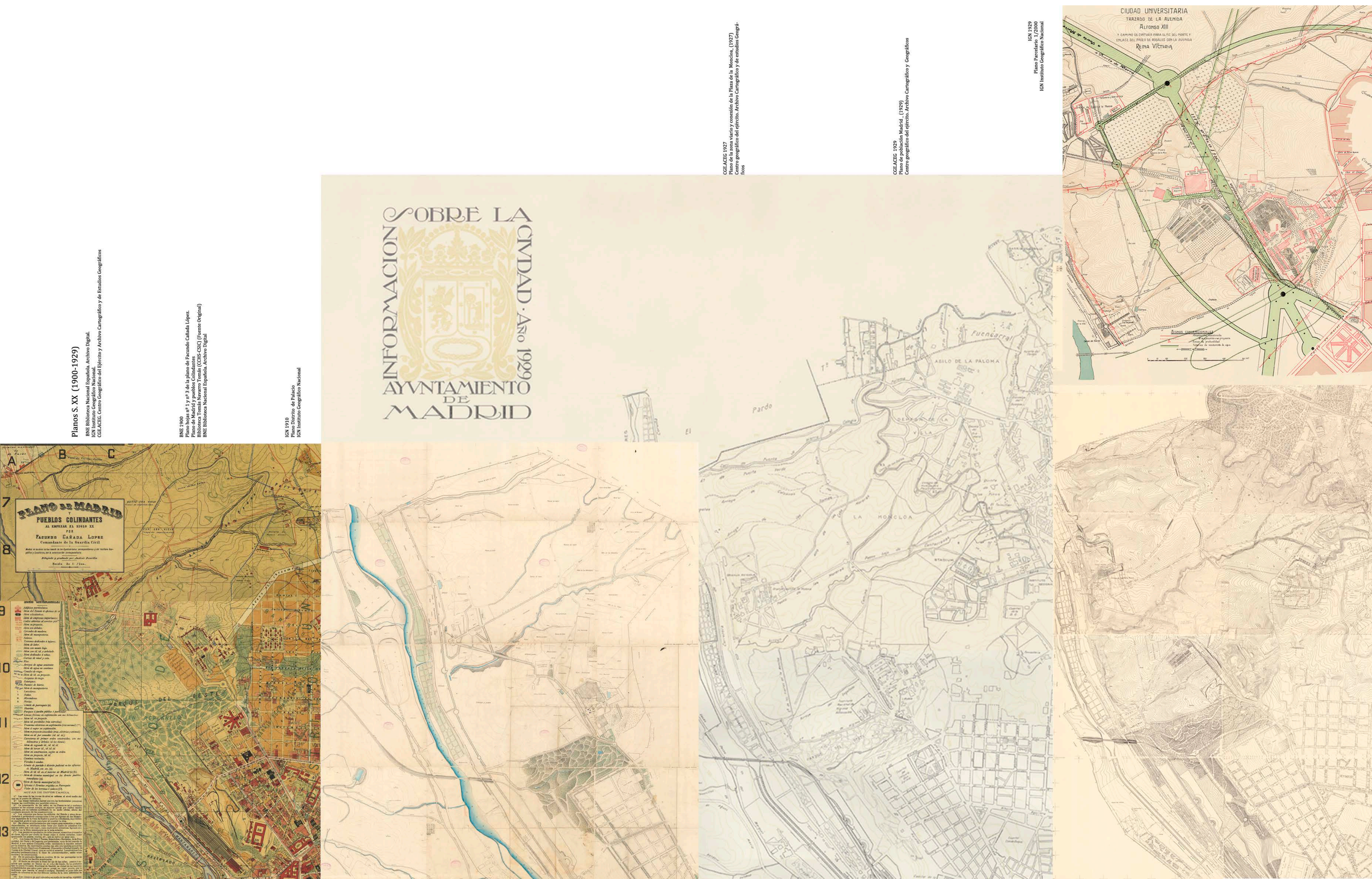

M DED
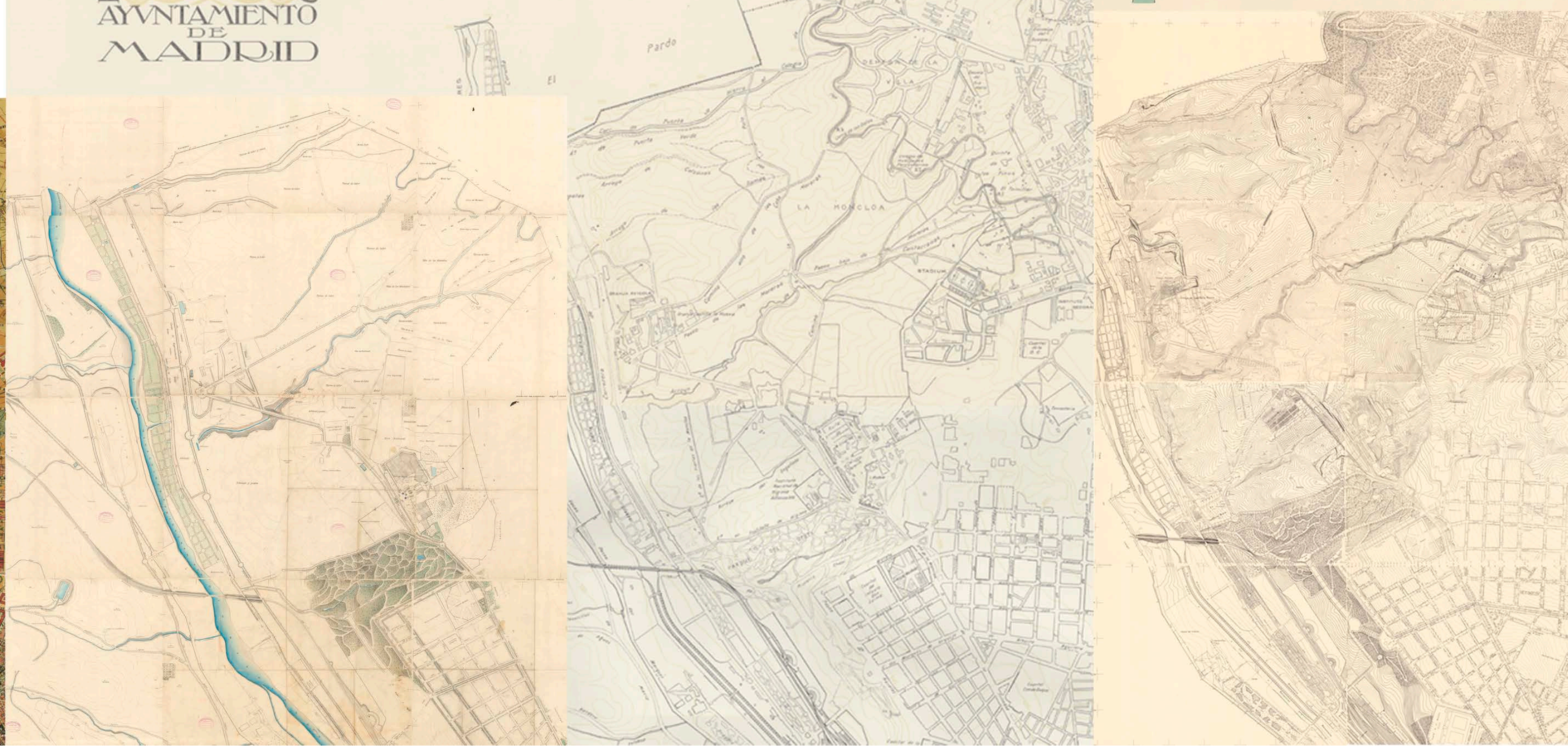
Detrás de todo buen proyecto arquitectónico - urbano existe un concepto, un núcleo generacional, una idea; y su construcción se basa en nociones de generación de la forma matemático - geométricas, y una base material que la sustenta aplicada con maestría en un contexto determinado. Para que una forma espacio-urbana tenga significación se requiere de un concepto que le de contenido, engendrado con una clara y potente intención que se apoye en el conocimiento del problema que implica el yo, los otros, el contexto sociocultural, el entorno.. ${ }^{1}$

${ }^{1}$ Coccato Juan Carlos . El concepto de forma en Arquitectura. Departamento de Morfología, Facultad de Arquitectura y Urbanismo UNNE. Área Digital Nro1, Resumen, Octubre de 2001. 
CAP2 _ FORMA [LO JUSTIFICADO] _ GÉNESIS

La Ciudad Universitaria de Madrid era un proyecto urbanístico y arquitectónico donde las edificaciones y espacios generados establecían una serie de relaciones, axialidades $y$ direcciones visuales por diversas operaciones de diseño y ordenación. De la forma en que se implantó anexa a la ciudad, se establecieron unas relaciones morfológicas y compositivas en el recinto escogido para ello. Dicho proyecto no se ejecutarían sin que antes se produjera un viaje, sin precedentes, para buscar una inspiración que cambiaría la historia y la fisionomía de la ciudad de Madrid.

Las ideas audaces son como piezas de ajedrez. Pueden ser vencidas, pero también pueden iniciar una partida victoriosa. Goethe (1749-1832) Poeta y dramaturgo alemán. 


\section{C.2.1_ UN GRUPO HETEROGÉNEO PARA UN PROYECTO UNITARIO}

Si el siglo XIX se caracteriza por el triunfo de la ciudad sobre el campo, el siglo XX será, y en buena parte se debe, a la victoria del campo sobre la ciudad; menos asfalto y más vegetación, menos ordenacismo y más personalidad, menos querer que el hombre se adapta a la arquitectura y más procurar que la arquitectura se amolde a la necesidades del hombre...2

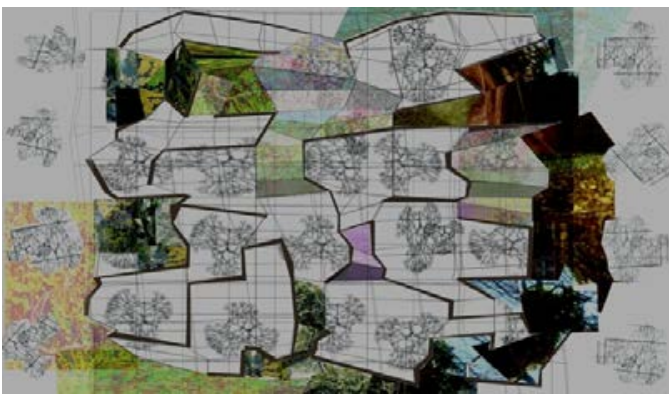

"Arquitectura doblegada por la naturaleza" Belén Butragueño Díaz-Guerra. Imagen de la propuesta para Becas "Caja de Arquitectos", 2001

Esta idea de la adaptación de la arquitectura a las necesidades, se reflejó en 1927 en el proyecto de La Ciudad Universitaria de Madrid como simbiosis entre conceptos antes alejados y ahora próximos, contestando a la necesidad de estar estos interrelacionados: Naturaleza y Arquitectura. Campo y Ciudad. Llenos y Vacíos. Formalismo y Funcionalidad. Conjunto y Orden frente a Individualismo y Anarquía.

El proyecto sería famoso en el extranjero, por verse como una idea novedosa para la nueva Europa, donde la cuestión de adaptación de la necesidad a la arquitectura se justificó en sus decisiones tanto formales como compositivas. Un proyecto que recogía los cambios ideológicos y artísticos que se estaban originando, e incluía las necesidades básicas sanitarias, docentes o incluso de publicidad al exterior, como se ha tratado en el capítulo anterior. Cambios y novedades, que se aplicaron también en la elección de un modelo de organización, peculiar para aquel momento: un equipo multidisciplinar, tanto técnico, administrativo como de financiación, ${ }^{3}$ para llevar a cabo la ejecución y materialización de la obra. Los arquitectos de la Generación del 25 solían trabajar en parejas o en solitario, pero nunca lo habían hecho en un grupo tan numeroso y todos bajo un plan director común.

\footnotetext{
2 Palabra de José Luis Arrese, primer ministro de Vivienda, articulo-obituario de la revista Arquitectura año 5, núm. 49.Enero 1963, sobre el fallecimiento de Modesto López Otero.

${ }^{3}$ Diéguez Patao, Sofía. La generación del 25. Primera arquitectura moderna. Cátedra. 1997. p. 10 
Un proyecto nuevo e innovador. Un proyecto hibrido entre tradición y modernidad. Un proyecto a modo de operación de prestigio para una ciudad y una nación, este estuvo expuesto en Nueva York en la Spanish Society donde fue muy alabado por miembros de otras universidades, como Columbia y Cornell ${ }^{4}$ y más tarde premiado en la Exposición de Barcelona de 1929 por un jurado internacional.

Las decisiones formales y la confluencia de estilos varios en el proyecto dependían exclusivamente de la Junta de Construcción de la Oficina Técnica, sin embargo, sus miembros proveían de diferentes enseñanzas e inclinaciones estéticas e ideológicas, por lo que en las propuestas presentadas como proyectos iniciales, fueron de muy diferentes estilos:

- Mezcla de influencias ente el clasicismo y el eclecticismo.

- Tendencias más académicas o tradicionalistas.

- Las nuevas ideas o concepciones mas propias de un posible Racionalismo.

- Ideas funcionales en planta y alzado, pero con la traslación a las fachadas principales de posibles formas más tradicionales y castizas. ${ }^{5}$

- Algunas formas de los modernismos, importados de Francia, Alemania o Italia, que tenían una ventaja ideológica y cultural, ya que no encontraban oposición a las nuevas corrientes vanguardistas. ${ }^{6}$

Esta mezclas de tendencias de sus creadores, fue el preámbulo que dio lugar una serie de proyectos heterogéneos de fuerte identidad individual pero que siempre han sido explicados y entendidos con una clara concepción unitaria y de conjunto. Concepción de unidad y conjunto, importante en este trabajo de investigación, que se explicará tanto durante el momento de la generación del proyecto como durante su ejecución y construcción, y que en capítulos próximos pondremos en consideración, duda y valoración.

El equipo de arquitectos para la Junta fue escogido por Modesto López Otero7, éste a su vez fue designado directamente por el rey, como director; formando el

4 Era un proyecto novedoso que se basaba en un $90 \%$ es su ideal de campus universitario americano, término y concepto de recinto universitario desconocido en España y Europa hasta ese momento. Por el hecho de llevar e imponer esta idea novedosa en Europa fue galardonado, no tanto de la idea en sí.

${ }^{5}$ Algunas de las fachadas podrían parecerse o recordad en orden y composición a las clásicas de algunos edificios de Alcalá, idea que respalda la mayoría de historiadores y la tesis de Pilar Chías.

${ }^{6} \mathrm{~A}$ veces mal interpretado tanto por el público o el pueblo español (que no las entendía) e incluso por los mismos arquitectos, las clases sociales altas y los intelectuales.

${ }^{7}$ López Otero, Modesto (Valladolid, 1885-Madrid, 1962) Arquitecto. En 1910 se gradúa en Madrid y llega a decano honorario del Colegio de Arquitectos de Madrid desde 1923 hasta 1955. Aunque colabora en la realización de monumentos conmemorativos y obras, como el edificio de La Unión y el Fénix de la calle Alcalá de Madrid, dedica la mayor parte de su carrera a la planificación y realización 
"Dream Team" de arquitectos madrileños del momento. Según artículos de la época, en su criterio de selección primó la experiencia previa en edificios aplicados a la investigación, enseñanza o sanidad. A cada arquitecto se le encomendó uno o varios proyectos, pero todos eran y serían un equipo. Aunque en esa época muchos de ellos ya habían trabajado juntos o por parejas, los arquitectosmiembros, de manera acorde debían redactar los proyectos repartidos bajo el plan común de ordenación urbanística para que el conjunto funcionara siempre con una composición formal base, unitaria y ordenada.

Es ese momento cuando empezó la concepción formal de proyecto, este seria urbano y arquitectónico a la vez, mas hibrido que heterogéneo. Un proyecto, que tiene que ser estudiado en su conjunto, como un compuesto o conglomerado de elementos arquitectónicos y urbanos, no puede ser entendido ni analizado de manera individual. Las arquitecturas y el urbanismo de la Ciudad Universitaria de Madrid como proyectos, en esta tesis serán interpretadas, como un todo.

La conjunción de diferentes formas de entender y realizar arquitectura, en edificios de uso parecido pero con muy diferentes programas, dentro de un plan ordenador, fue una ardua y dura tarea. Un difícil compromiso tanto de los académicos, como de los arquitectos y el resto de los miembros de la Junta, sumando a todo ello que muchos programas, de uso, estancias o función, no se regían solamente por las necesidades docentes básicas o necesarias, sino también por las exigencias de despachos y cátedras con sus respectivas dependencias espaciales a petición de académicos de mayor o menor peso político. Idea que expone claramente Luis Lacasa en sus escritos, junto con la forma de dirección de obra de aquellos tiempos. La política, podemos decir, estuvo presente en algunos momentos clave del desarrollo del proyecto, entorpeciendo en la mayoría de los casos, y mas adelante se explicaran las razones, al desarrollo de una arquitectura real, funcional que debía ajustarse a las necesidades docentes que se pretendían y no siempre se hizo.

Dentro de la Junta Constructora, al igual que había miembros de diferentes inclinaciones políticas, había otros con diversidad de criterios sobre el Plan de Conjunto, o sobre los criterios estéticos o formales de la arquitectura de las edificaciones que se tendrían que aplicar. No coincidían con el resto de miembros: Luis Lacasa y Sánchez Arcas, por un lado, Agustín Aguirre, Miguel de los Santos y Pascual Bravo, por otro, y Modesto Lope Otero siempre como mediador.

de la Ciudad Universitaria de Madrid, que comienza en 1927. Al instaurarse la Segunda República, López Otero fue relevado de la dirección técnica y sustituido por el arquitecto Sánchez Arcas. 
Era un grupo de arquitectos heterogéneo pero en el que debía imperar esa ley ordenadora común y necesaria, para así adaptarse y llevar a cabo un proyecto de gran dimensión tanto política como conceptual, y lo mas importante a diferentes escalas tanto en extensión como de diseño o detalles arquitectónico. En la mayoría de los escritos, o artículos consultados sobre La Ciudad Universitaria de Madrid impera y se elogia este hecho de unidad y conjunto, el olvido de la diferencia tanto ideológica y estilística de cada arquitecto, ejecutando cada uno su propio proyecto muy próximo a otros en distancia, quizá pudo mejorar las tensiones que si surgieron y que mucha veces se obviaron a favor de la idea de proyecto unitario ${ }^{8}$.

MODESTO LOPEZ OTERO (Director)

- Proyecto urbano y organización de Campus (1927-1936)

- $\quad$ Proyectos del Paraninfo (1920-1950-...)

LUIS LACASA

- Residencia de Estudiantes (1928-1932)

MANUEL SANCHEZ ARCAS

- $\quad$ Pabellón de Gobierno (1932-1936)

- Central Térmica (1933-1935)

- Hospital Clínico-San Carlos (1932-1936)

MIGUEL DE LOS SANTOS

- $\quad$ Facultad de Medicina (1930-1935)

- $\quad$ Facultad de Odontología (1930-1936)

- $\quad$ Facultades de Ciencias (1930-1936)

- Hospital Clínico San Carlos (reconstrucción) (1941-1946)

AGUSTIN AGUIRRE

- $\quad$ Facultad de Farmacia 1930-1935

- Facultad de Filosofía y Letras 1932-1936

- Hospital Clínico San Carlos (reconstrucción) (1941-1946)

PASCUAL BRAVO

- Escuela Técnica Superior de Arquitectura de Madrid (1933-1936)

- $\quad$ Arco del Triunfo de la Moncloa (1950-1956)

RAFAEL BERGAMIN Y BLANCO SOLER

- $\quad$ Fundación del Amo (1928-1930)

EDUARDO TORROJA (ingeniero)

- Obras de Infraestructura, alcantarillado y red de saneamiento

- Viaductos (Aire, Deportes y Quince Ojos, Damas y Palacete)

- Muros de Contención (Zona el botánico y zona de Paraninfo)

El director Modesto López Otero, al que se le atribuye, una clara influencia decimonónica y ecléctica, intentó adaptarse a la modernidad y a las arquitecturas de las primeras décadas del siglo XX. Una actitud bastante progresista que le llevarían a él y al resto de arquitectos, a tener momentos de contraposición y diferencia de soluciones a adoptar, pero que generaron un proyecto lleno de tensiones, espacios y relaciones, tanto en trazado como en soluciones formales de heterogeneidad estética. Aparte de los arquitectos escogidos para las distintas

${ }^{8}$ Luis Lacas en su libro Escritos. 1922-1931 lo compara el proyecto de la nueva universidad para Madrid con la obras Versalles de un nuevo Rey Sol, y otros con la obra del reinado de Felipe II y el Monasterios del Escorial. 
edificaciones, tuvo gran importancia la elección del ingeniero de Caminos, Eduardo Torroja Miret ${ }^{9}$, para el cálculo de estructuras y búsqueda de soluciones de infraestructuras e ingeniería en la mayoría de las mismas. Al trabajar tanto con arquitectos, su concepción de la formal, la función y la técnica le hacían a veces pensar mas como diseñador que como ingeniero.

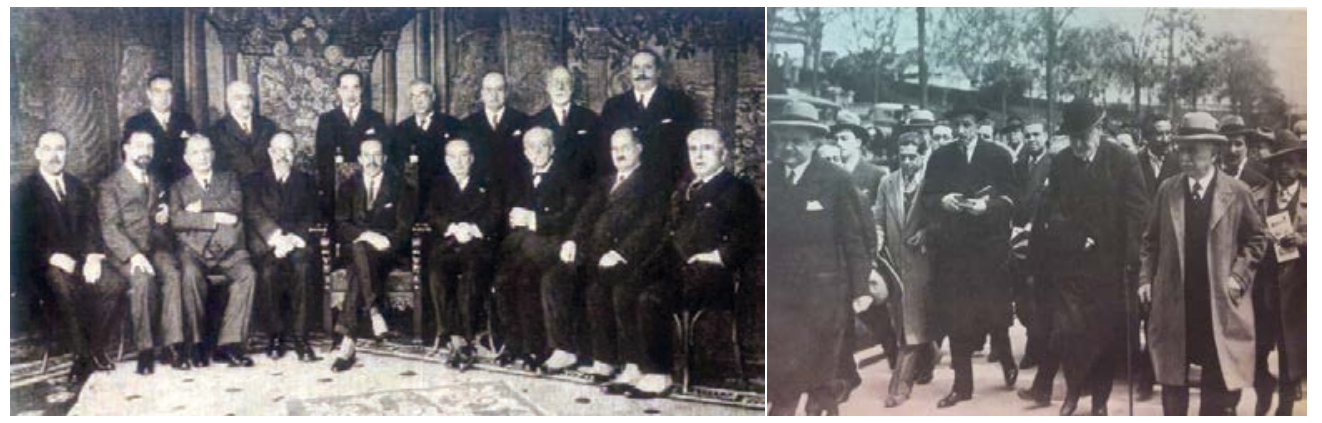

Fig.1. Fotografía de los miembros de la Junta Constructora 1931.

Fig.2. Fotografía de la junta de paseo por los terrenos de la universitaria del rey Alfonso XIII, junto con el alcalde de Madrid, José Francos Rodríguez, el arquitecto Modesto López Otero y Florestán Aguilar. Revista de Arquitectura Nacional nํ⒍1943

En la Revista Nacional de Arquitectura de Enero 1963 del COAM, año 5, núm. 49, en un artículo obituario sobre Modesto López Otero, compañeros de profesión hacen mención al carácter mediador, templado, humilde y generoso de este arquitecto; no es raro por tanto pensar porqué el arquitecto "organizador" y "coordinador" del proyecto, solo se quedara con el plan director y urbanizador, pero reservándose la cabecera que nunca se llegó a construir ${ }^{10}$. Para algunos, esta actitud de dejar de lado las ideas previas de acuerdo a su formación ecléctica, para dar paso a ideas más pragmáticas, racionales organizativas y más relacionadas con la coordinación técnica y económica eran quizá una postura para reservase el protagonismo después. Él haría la labor mas difícil, ser el director de orquesta, dirigiendo a los arquitectos como músicos para que proyectaran en armonía, de igual modo que organizaría los elementos y edificaciones en la trama urbana para que formalmente funcionaran como una obra musical melódica. ${ }^{11}$

\footnotetext{
${ }^{9}$ Casi todas los cálculos y diseños de las estructuras de las obras fueron realizadas por este ingeniero de caminos, considerado durante su vida un genio en el cálculo de estructuras de construcciones de hormigón armado. Era especialmente conocido por el diseño y cálculo de la cubierta del Frontón de Recoletos y de una estructura innovadora como fue el Hipódromo de la Zarzuela de Madrid. Ambos resistieron, como la mayoría de sus obras de La Ciudad Universitaria, (como se explicaran en el siguiente capítulo de este trabajo de tesis) los ataques y envistes de la Guerra Civil española.

10 Zona de el Paraninfo Norte, entre los grupos de Ciencias y Letras, donde se ubicaría el edificio cabecera y principal del conjunto, que nunca se llegó a construir aunque si quedaron numerosos bocetos, croquis e ideas graficas del proyecto fechados en diferentes momentos de la historia de la universidad.

${ }^{11}$ Siendo él, el director, se reservó una obra emblemática, aún a sabiendas, que por necesidad y urgencia de ejecución, quizá nunca se realizaría
} 


\section{IDEALES IMPORTADOS PARA LA UNA NUEVA UNIVERSIDAD}

Las ansias de renovación y de modernidad de los integrantes de la Oficina Técnica hicieron que La Ciudad Universitaria se convirtiera en un campo de experimentación y ensayo. Un verdadero laboratorio urbano de aquel momento.

Los estilos adoptados recuerdan vagamente a los empleados en la Universidades norteamericanas de la época, pero resueltos aquí según la personalidad de cada autor ${ }^{12}$

¿Cómo un proyecto con un concepto novedoso y nuevo, se implantaría en España con una variedad tal de arquitectos y trabajando bajo un sólo plan director? ¿Podría el proyecto superar las ideas y las intenciones propias del individualismo arquitectónico de cada edificio? ¿Son los proyectos de cada zona, independientes entre sí? ¿Prima más las obras o el espacio entre ellas? ¿Cómo se relacionan, que geometría formal, espacial y constructiva del proyecto que se ejecutó?

La Ciudad Universitaria podría decirse que fue, a pesar de la idea motriz de unidad y orden en el planeamiento y zonificación, como se suele definir, un proyecto de lucha de cada uno de sus elementos frente a un todo, de cada arquitecto frente a la junta, de los edificios frente a la trama y la ordenación. Una lucha que se establecía desde los trazos iniciales en una serie de relaciones, axialidades y direcciones compositivas contrapuestas, por diversas operaciones de ordenación en la que se implantó estableciendo un diseño morfológico en un terreno escogido para ese fin en concreto.

Los primeros bocetos, planos y tanteos, insertando la traza en el lugar, parecen ser ordenada y vinculando siempre las construcciones, zonas y grupos entre sí , por las vías de comunicaciones a modo de piezas de unión, entre ellas y con la ciudad

Una idea de un "campus" 13 diferente, que habría sido planteado e ideado simplemente como un recinto docente o un espacio universitario como tal, pero del que se modificó su destino, tras un "viaje de ideación” previo y por el resultado de la mezcla de ideas, e influencias arquitectónicas exteriores de aquel momento:

\footnotetext{
12 José Luis Arrese, primer ministro de Vivienda, Articulo de la revista Arquitectura año 5, núm. 49 Enero 1963 sobre el fallecimiento de Modesto López Otero

13 Termino de origen americano que hace referencia al Espacio, terreno, edificios y jardines pertenecientes a una universidad. Se podrá utilizar haciendo referencia a las distintas zonas- plazas o espacios en que se pueden dividir los recintos universitario docentes y de investigación.
} 
- La mezcla de estilos entre la tradición compositiva en planta de la Écols de Beaux Arts, el monumentalismo escenográfico y el eclecticismo. ${ }^{14}$

- La influencia de las visitas-recorrido de las Exposiciones Internacionales ${ }^{15}$ y extremando el énfasis de la axialidad.

- Y la utilización de los criterios de zonificación por la influencia higienista16 que se impuso como necesaria en esta época (volumen, aires, luz, viento, iluminación y espacio)

Palabras como "heterogéneo", "híbrido" o "mezcla", aparecen como definidores de este campus madrileño en 1927, quizá por las corrientes europeas de zonificación, ideas higienistas, o cambios arquitectónicos que estaban en proceso de consolidación en aquel momentos entre viejos y nuevos modelos. Términos que aparecen describiendo y evidenciando la superposición de criterios de aproximación al proyecto arquitectónico que se generó, mientras se ideaba y se originaban los primeros proyectos arquitectónicos para el recinto universitario.

Para algunos autores o críticos de estilo, la influencia de la arquitectura norteamericana superó a la tradición clásica de la época. Se podría decir que los primeros edificios iniciales que se proyectaron de la universidad, no eran racionalistas sino funcionales y clasicistas, pero sin olvidar el uso de la buena técnica constructiva y de materiales. Por esta marcada influencia se pueden caracterizar a los edificios, sin ámbito de duda, como el resultado de la inspiración americana por la que se engendraron.

Entre las numerosas muestras que utilizaron, quizá las más claras serían: La Universidad de Virginia en Charlottesville, La Universidad de Columbia en Nueva York o la Universidad de Pittsburg en Pennsylvania, buscando y encontrando semejanzas o detalles inspirados en los ornamentos clasicista, academicistas o de Art Decó de las universidades europeas, pero con valores e innovaciones constructivas con los avances de la época en España, sin olvidar que implantaban una nuevo concepto espacial con una composición formal y planimetría basada en los modelos espaciales y urbanos de campus de los recintos americanos

\footnotetext{
14 Tanto de edificios con su fondo natural como en el recorrido jerárquico por la avenida.

15 Se utilizarían los recorridos efectistas en varios de sus ejes.

${ }^{16}$ El Movimiento higienista arquitectónico y de urbanístico aparece a finales del XIX en Inglaterra, pero se hace aplicable en arquitectura a principios del siglo XX, con el desarrollo de las teorías higienistas. Es el resultado, de los trabajos de médicos, científicos y políticos luchando contra la insalubridad de las viviendas parisinas y la propagación de la tuberculosis. En relación a arquitectura y a la enseñanza se basaba en que el volumen de las aulas y la medida de las ventanas, fueron calculadas según los datos científicos de la época para optimizar la oxigenación y las horas de sol para los jóvenes alumnos, en la mayoría de todas las escuelas en Francia.
} 
Este trabajo de influencias o análisis de estilos, no es el fin mismo de esta tesis, pero si es importante remarcar la concepción formal y espacial de aquellos campus; como un camino y punto de apoyo para analizar e interpretar las decisiones del proceso del proyecto, el diseño y espacialidad acertadas o equivocadas; con las ideas o conceptos que se adquirieron como punto de partida y que se implantaron en el proyecto urbano y arquitectónico en la universidad de Madrid.

El valor conceptual de dichas decisiones y conceptos que se aplicaron en el recinto universitario en la finca de La Moncloa para crear formas, trazas y morfologías espaciales de proyecto, son de clara apreciación posterior del carácter arquitectónico y paisajístico ${ }^{17}$ que marcaron el lugar de manera determinante.

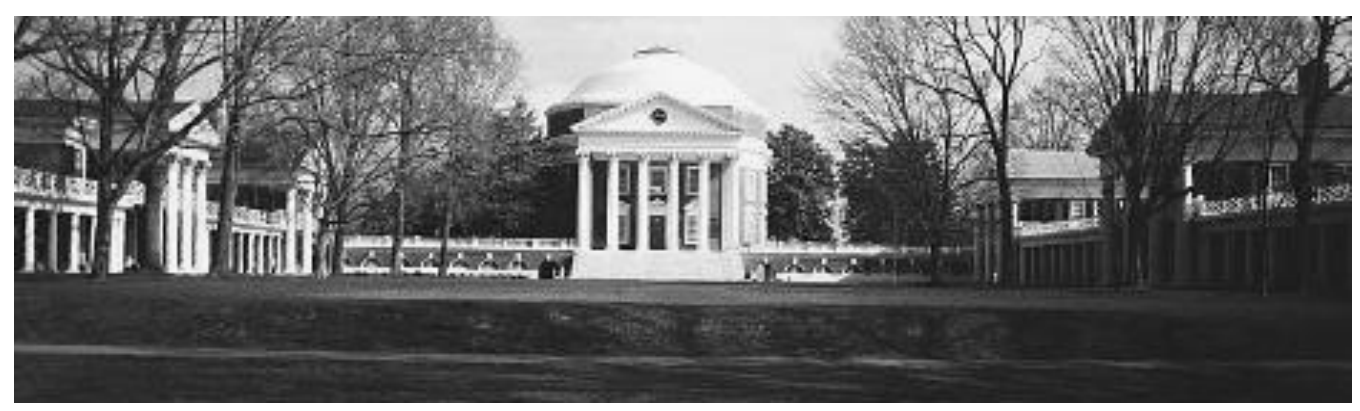

Fig. 3. Universidad de Virginia en Charlottesville-

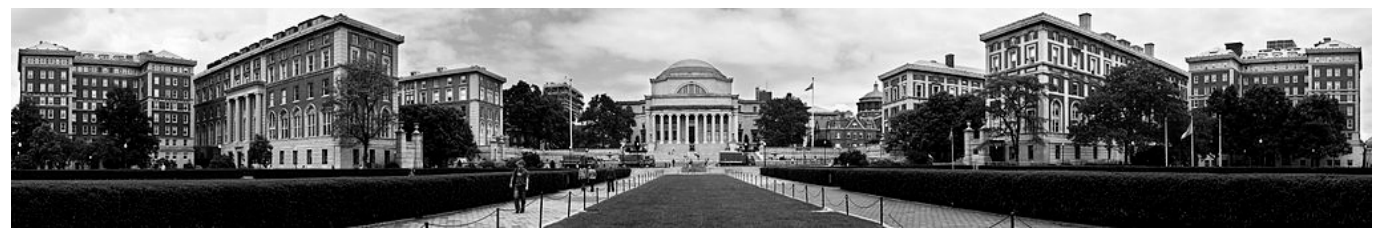

Fig. 4. Universidad de Columbia-

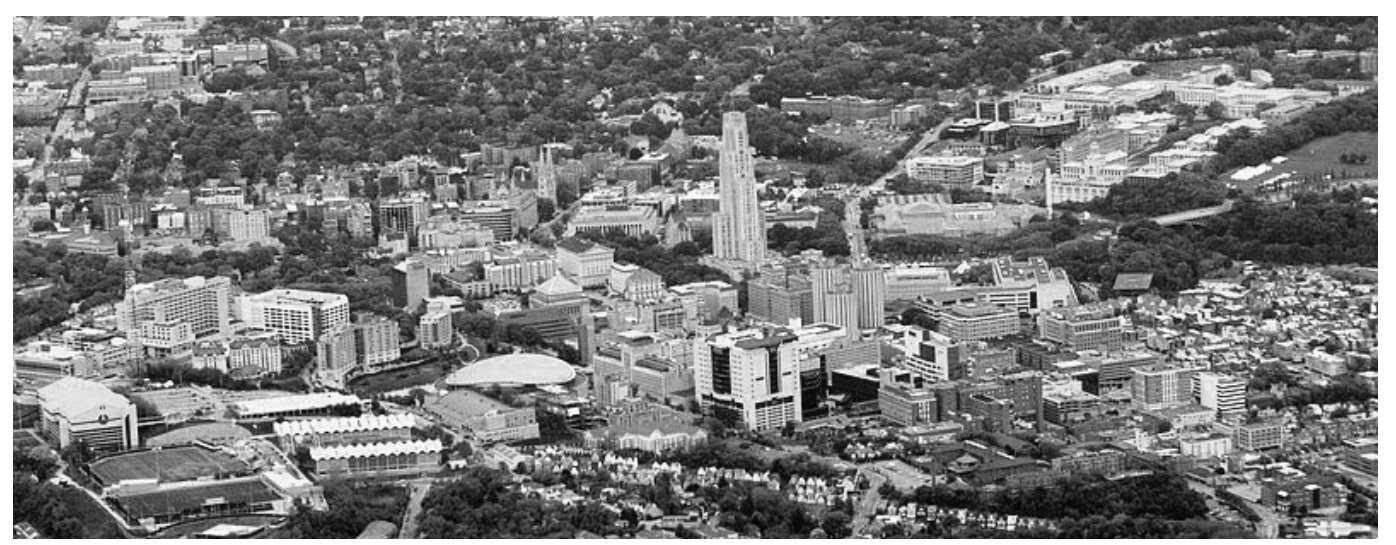

Fig.5. Universidad de Pittsburg en Pennsylvania (Universidad de Pitt)

${ }^{17}$ Se desarrollarán y se detallarán los diferentes paisajes bajo un análisis espacial por la toma y ejecución de estas decisiones proyectuales. 


\section{IMAGEN}

PUNTOS DE REFERENCIA

\section{MATERIALES}

\section{PAISAJE}

ESTILO

Uso de los campus

Redes- Caminos de Circulacin

Localizacion de las edificaciones

Medio Ambiente

Infraestrucucturas
1. Un campus es una obra de arte cuya administración debe llamar la atención y el respeto de las sucesivos generaciones.

2. El arte se expresa a través de la fusión de edificios y paisajes en un entorno físico diseñado llamado "campus".

3. Los diseños de los campus en el lugar apropiado deben reflejar una propósito, los logros y aspiraciones de la institución que representan.

4. La adecuación se logra al resolver el problemas de continuidad y cambios, de los elementos físicos y las formas que generan el diseño del campus.

5. Para dar y no menospreciar el legado de diseño del campus es demostrar la vitalidad de una institución simbólica

6. Cada institución debe realizar una evaluación de su diseño de campus patrimonio - la identificación de los edificios y paisajes que son o podrían ser componentes esenciales en la creación o el mantenimiento de la imagen de la escuela y el sentido del lugar.

7. Constituida en el plan general de la escuela, la evaluación se debe utilizar para buscar y gravar los fondos para conservar, mejorar y ampliar el diseño del campus como legado. Un legado que legitima y proclama la institución.

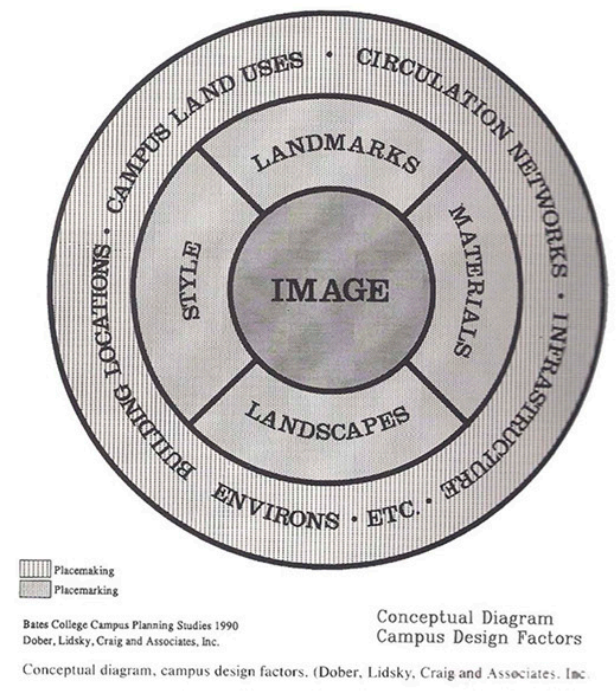

SCUP SEATTLE STATEMENT

1. A campus is a work of art whose stewardship should command the attention and respect of successive generations.

2. The art is expressed through the melding of buildings and landscapes into a physical environment called the campus design.

3. Appropriate campus designs define and celebrate an institution's purpose, territory, accomplishments and aspirations.

4. Appropriateness is achieved by addressing and resolving the

5. To deny or demean the campus design legacy is to diminish an institution's vitality - symbolically or actually.

6. In support of this statement of principle, each institution should undertake an assessment of its campus design heritage - identifying those buildings and landscapes which are or could be essential components in creating or sustaining the campus image and the sense of place.

. Incorporated in the overall campus plan, the assessment should be used to seek and encumber funds to conserve, enhance and enlarge the campus design legacy - a legacy hat legitimizes, facilitates and proclaims the institution's

A statement of principle on campus design adopted by the Society for
College and University Planning, 1991.

Fig. 6. Diagrama conceptual. Factores esenciales de diseño de campus universitarios

Fig. 7. Estamentos principales en el diseño del Campus (Dober, Lidskin, Craig y Asosociados,) Dober, Richard P. Campus design. Wiley, 1992. (Edicion Original 1976). p.p. 12-15 
La concepción e idea de una nueva universidad comienza, como se ha visto en el primer capítulo LUGAR [LO CONTEXTUAL], cuando el rey Alfonso XIII, decide crear "la obra de su reinado". La universidad como un nuevo modelo reuniendo a los arquitectos, junto con filósofos y humanistas. A ellos les encargaría la función de diseñar en todos los ámbitos, disciplinas y técnicas el proyecto. Esta junta fue llamada "Junta Constructora", siendo los arquitectos, anteriormente citados con sus respectivas obras, los encargados de su construcción ${ }^{18 .}$ Se buscaba crear un espacio dedicado al saber para una ciudad que se estaba trasformando y que también reclamaba un proyecto trasformador universitario, a la vez actual e innovador. ${ }^{19}$.

He pensado en la necesidad de emprender la construcción de los edificios de una gran Universidad 20

Nuevas ideas filantrópicas y humanistas que se debía traducir en arquitectura y por qué no, en el primer complejo universitario de Europa pero aplicando ideas formales, espaciales y compositivas, nuevas. Propias de las nuevas necesidades y tendencias. ¿Pero cómo y dónde buscar estas nuevas ideas?

La evolución a las universidades americanas desde la tradición de las universidades inglesas antiguas, junto con algunas características de modelos europeos germánicos, serían la respuesta. Ideas espaciales, compositivas y arquitectónicas importadas que, como se comprobará con el resultado del proyecto ideal original, no debían olvidar las ideas humanistas, sociológicas, y espirituales propias de la institución de la universidad y de la nación.

El trabajo de la Junta debe encaminarse, no solo a plantear los edificios, sino a lograr que la Ciudad Universitaria sea una institución modelo que sirva para regenerar y perfeccionar la educación superior y donde el estudiante viva en un ambiente $y$ encuentre cuanto necesita para su bienestar espiritual y físico"21

\footnotetext{
${ }^{18}$ El 3 de diciembre de 1928 se promulgo el Real Decreto Ley por el cual la finca de la Moncloa, que pertenecía al estado, pasase junto con otros terrenos monárquicos y cesiones a depender del Ministerio de Instrucción Pública y Bellas Artes y sirvieran de emplazamiento de la nueva Universidad.

19 Toda esta idea se plasmó en el Real Decreto de 17 de Mayo d 1927 creando una Junta Autónoma con personalidad jurídica propia, ejerciendo el Rey su presidencia, legando parte de terrenos monárquicos para su localización.

${ }^{20}$ Conversación en 1924 entre Alfonso XIII y algunos arquitectos que habían acudido al Congreso Nacional de Arquitectos de Santander, sobre la nueva Ciudad Universitaria.

${ }^{21}$ Declaración de intenciones de la Junta como explicación de su labor a la opinión pública. Acta 1 de Junio de 1927. Notas. Chías Navarro, Pilar. Tesis. La Ciudad Universitaria de Madrid. Planeamiento y Realización. ETSAM 1983
} 
La Ciudad Universitaria de Madrid, según Antonio Bonet Correa, fue considerada como "La nueva Atenas", "La ciudad platónica del Saber", el "Templo de la sabiduría", ya que suponía una universidad novedosa, un recinto universitario americano diferente de las universidades europeas instaladas en pleno centro urbano o con formas compactas en recintos pequeños. Según sus palabras durante uno de sus discursos universitarios: La Ciudad Universitaria era y fue no sólo una realización posible sino también un símbolo de la cultura moderna a la que, con pleno derecho, aspiraba España.

La decisión de utilizar unos terrenos de propiedad real implicaría una gran remodelación, planificación y trasformación completa de esta parte de la urbe para llevar a cabo los planes del proyecto. Dichos planes del proyecto no se ejecutarían, sin que antes se produjera ese viaje de inspiración y esa razón proyectual que cambiaría la historia y la fisionomía de la zona norte de ciudad de Madrid. Era por tanto necesario, y así lo hicieron, estudiar previamente los diferentes tipos de ciudades y recintos universitarios que ya existían más allá de las fronteras españolas. La universidad entendida como ciudad o "microciudad"22, dentro o anexa a otra, no solo como elemento o piezas arquitectónicas individuales e inconexas, como habían sido hasta ese momento.

Lo mas anecdótico de este viaje, es que el artífice del mismo fue el amigo y dentista del rey, Florestán Aguilar ${ }^{23}$ que había informado, gracias a su etapa de estudiante en EEUU, de la existencia de recintos universitarios donde los pabellones se distribuían aislados dentro de un recinto delimitado, algunos con más o menos carácter monumental; pero de marcadas volumetría y orden entre sí, sólidos y de sencillos materiales, con grandes vanos de ventanas que proporcionaban luz y aire abundantes. Era lo que allí se llamaba "campus". Un conjunto de volúmenes arquitectónicos que creaban un conjunto o complejo espacial de relaciones con finalidades docente y vivencial.

El viaje que realizó en el año 1927 por Europa y América del Norte, generó gran cantidad de información, datos, croquis y apuntes que se mandaron regularmente a la Junta. Información que se ordenó y se clasificó para tomarla como base en la

22 Chías Navarro, Pilar. Tesis. La Ciudad Universitaria de Madrid. Planeamiento y Realización. ETSAM 1983. P. 62.

23 Don Florestán Aguilar y Rodríguez, Vizconde de Casa Aguilar, obtuvo. Licenciado y Doctor en Medicina y Cirugía en la Facultad de Madrid, estudió Odontología en Filadelfia. Se estableció en Madrid como ayudante de un doctor que prestaba sus servicios en la Casa Real. Gran amigo del Rey Alfonso XIII, se involucró activamente en la iniciativa del Rey Alfonso XIII para la construcción de la Ciudad Universitaria en la Moncloa, debido a sus conocimientos en los medios y formas de la docencia universitaria americana, donde él había estudiado. 
ejecución posterior del proyecto ${ }^{24}$.La idea de mandar a López Otero al viaje inicial, al igual que posteriormente encargarle a él la dirección urbana y arquitectónica de todo el proyecto, fueron quizá las ideas previas más sensatas e idóneas 25 . Se realizaron dos viajes, el primero europeo ${ }^{26}$ y el más importante el transoceánico a Estados Unidos y Canadá (costa este).

\begin{tabular}{|c|}
\hline Viaje previo en Solitario de López Otero a: \\
\hline Hamburgo, Copenhague, Berlín, Praga, Varsovia, Zúrich \\
\hline Viaje por EUROPA: \\
\hline En Europa a centro universitarios-sanitarios y hospitales: \\
Estrasburgo, Lyon, Varsovia, Londres, y Cambridge \\
\hline Viaje por EEUU y Canadá: \\
\hline $\begin{array}{c}\text { New Haven, Boston(Harvard y MIT ) Montreal (Mc Gill, Universidad de Montreal) Toronto (Universidad } \\
\text { de Toronto) Ann Arbour, Rochester, Washington (Universidad de Georgetown, } \\
\text { University, George Washington University) Baltimore (Universidad de } \\
\text { York (Universidad de Columbia) }\end{array}$ \\
\hline
\end{tabular}

Tras el viaje de vuelta, sus cuadernos, notas, bocetos y dibujos vinieron cargados de nuevas conceptos y terminologías que serían la base para la nueva experiencia en el proyecto de campus madrileño. El proyecto que se empezó a generar como idea en 1924, se comenzó en 1927 y su construcción empezó en 1928, siendo el lugar físico escogido La Finca de la Moncloa, el contenedor o laboratorio de las nuevas tendencias proyectuales importadas

NOTA: VER Anexo c2_El Viaje de la nueva realidad

\footnotetext{
${ }^{24}$ Ese proyecto contó con estudios preliminares y numerosos proyectos que se desarrollaron para cada fase, siendo la primera solamente la que se pudo ejecutar ante de que empezara la Guerra Civil en 1936. Los más de 5.000 planos y un avance del presupuesto de 250 millones de pesetas para todo el complejo, da idea del grandioso y amplio proyecto inicial que podría haber sido si las tres fases se hubiera ejecutado y construido de manera ininterrumpida.

25 Ideas y opinión que quedan constancia en la mayoría de los libros de Pablo Campos Calvo-Sotelo y en el resto de libros y artículos del mismo autor .

${ }^{26} \mathrm{La}$ ausencia de grandes desarrollos universitarios determinó que la visita fueran más a centros sanitarios, hospitales y de laboratorios, mientras que en América se centraría más en los campus.
} 

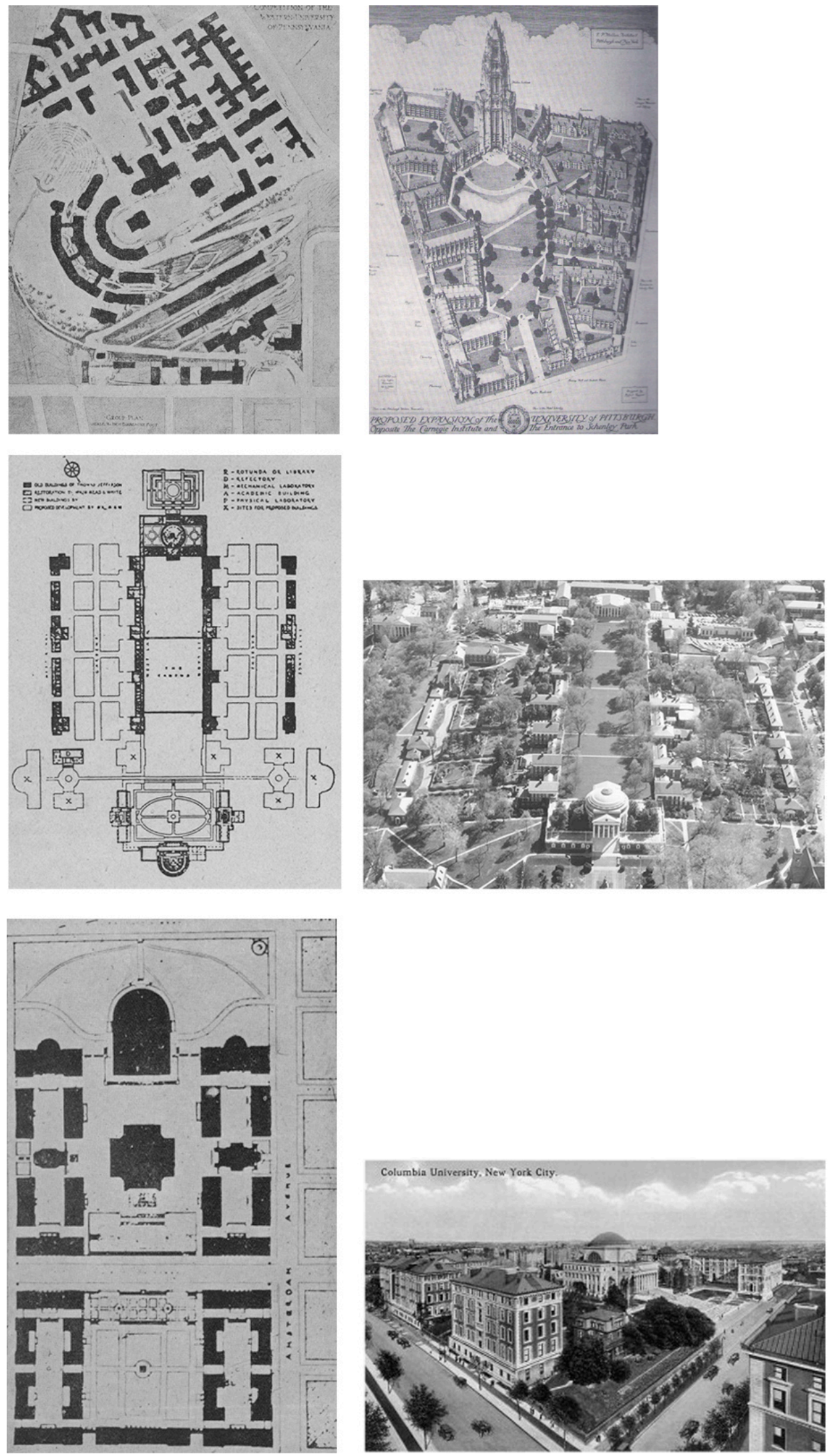

Fig. 8. Universidad de Pittsburg en Pennsylvania (Universidad de Pitt).

Fig. 9. Universidad de Virginia o Jefferson en Charlottesville.

Fig. 10. Universidad de Columbia- en Nueva York. 


\section{C.2.2_CIUDADES DEL SABER. EL ESCENARIO URBANO-UNIVERSITARIO}

La universidad como institución en el desarrollo arquitectónico y urbano, comienza en la historia de Occidente en la época medieval, siendo en este momento cuando se empieza a considerar un mundo propio y autónomo. El saber como concepto universal. La Universidad como resultado de la unión entre escuelas libres y grupos de estudiantes y maestros con estatutos y privilegios propios. Todo esto unido a que los edificios y las áreas eran un territorio aparte con característica propias (lo que antiguamente denominaban "Palacios de las Musas" o actualmente "Ciudad del Saber") les han hecho ser merecedoras de una evolución arquitectónica exclusiva en sus formas, ya que desde el pasado las universidades han mantenido un modo de vida único y diferente. ${ }^{27}$ Un modo de vida donde rigen las duplicidades:

- La unión del saber y el conocimiento.

- Los estudiantes y profesores.

- El espacio y el lugar.

Hay que recordar que la Universidad, independientemente de su desarrollo o relación con su entorno circunstancial, siempre forma un mundo unitario en sí mismo, cerrado en un territorio aparte y diferente del que le rodea. Es un espacio distinto, esté o no delimitado físicamente, esté o no inserto en la ciudad o en la periferia. Es un espacio-ciudad autónomo y aislado. Es una ciudad liberada e independiente de la ciudad en la cual se encuentra ubicada, tanto de manera anexa, periférica o completamente integrada. Siempre habrá una barrera psicológica de forma de vida en un espacio del saber, aunque esta barrera sea imaginaria o simplemente sensorial. Será esta la barrera por lo que tratamos al recinto y espacios de la universidad o campus como islas, acrópolis o palacios, todos ellos elementos con un claro sentido perimetral y de unidad independiente del contexto urbano.

Durante el proyecto de ideación de la Ciudad Universitaria de Madrid, esta mentalidad de hacer un ente separado supuso una concepción moderna con respecto a la tradición, la Universidad-Antigua frente a la Universidad-Nueva. La supuesta dicotomía entre los patios medievales o el campus americano, el espacio urbano de la Universidad renacentista frente al espacio frontera de la Universidad más reciente como modelos muy diferente, como ejemplos pioneros de la universidad de origen y estilo medieval construida a base de edificios y centros distribuidos o ubicados sin ninguna relación entre ellos por la capital.

27 Bonet Correa, Antonio. Arquitectura y universidad. Del palacio de las musas a la ciudad del saber. Instituto de España, Madrid. 2002 y articulo "La Ciudad del Saber". Ciudad, universidad y utopía. 1293-1993. COAM, 1995 pp. 49-61 


\begin{tabular}{|l|}
\hline UNIVERSIDAD RENACENTISTA XII-XV- Patios monásticos-Espacio Urbano \\
\hline UNIVERSIDAD RECIENTE- XIX-XX- Campus Americanos- Espacio Frontera \\
\hline
\end{tabular}

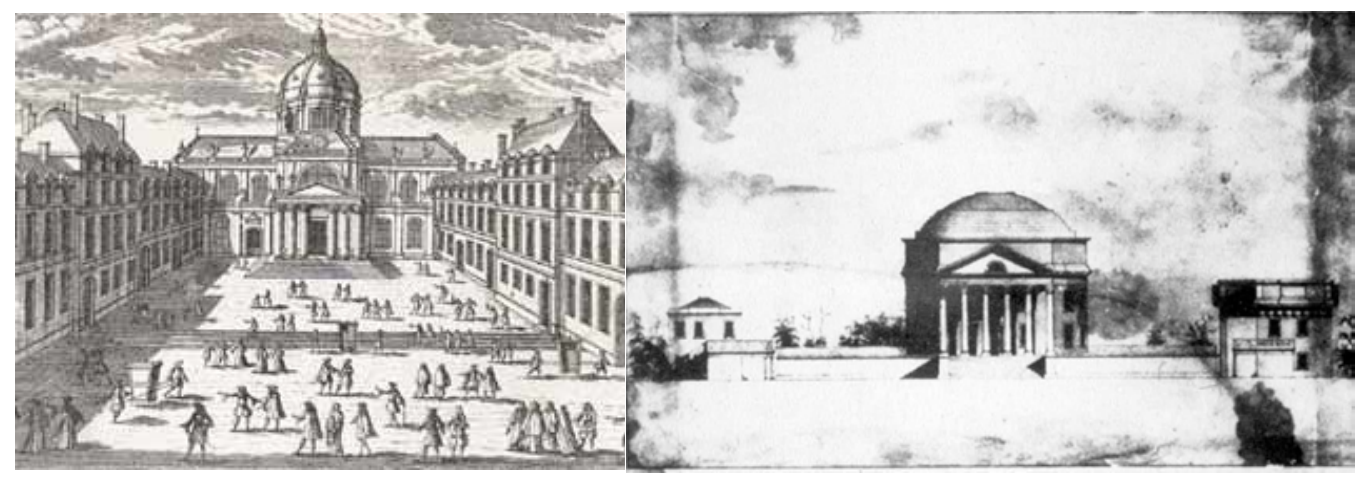

Fig. 11. Universidad la Sorbona. Univ. Renacentista- Patios Monásticos.

Fig. 12. Universidad de Virginia Univ. Reciente- Campus Americano.

Los antecedentes históricos previos en Europa, empieza con universidades como La Sorbone, Bolonia u Oxford que se trasformaron rápidamente en ciudades de carácter universitario, en contraposición a otras españolas como Salamanca o Valladolid u otras extranjeras como Cambridge, Heidelberg o Pisa que continuaron como centros universitarios dentro de una ciudad de tamaño medio. La variedad de ciudades de carácter urbano-universitario, no hacía pensar cual sería la deriva o el desarrollo de La Ciudad Universitaria de Madrid con respecto a la ciudad que la mantenía y en la que se apoyaba. ¿Podría quedar el recinto que se había escogido para implantar la universidad, asfixiado o absorbido por la urbe? ${ }^{28} ¿ 0$ se podría mantener como una zona autónoma pero anexa e independiente?

La idea inicial para proyectar el recinto tomaría los mejores modelos hasta ese momento desarrollados, en base a los posibles futuros fines e ideas que podrían ocurrir. Ejemplos americanos y canadienses como, los que hemos nombrado antes (Universidad de Virginia en Charlottesville, La Universidad de Columbia en Nueva York o la Universidad de Pittsburg en Pennsylvania) pero también con influencia o detalles de soluciones de otros, como la concepción espacial en cuesta de los terrenos de la Universidad de Berkeley, o el monumentalismo y uso de hitos o terrazas de la Universidad de Montreal, que distaban mucho de lo que se conocía hasta ese momento en Europa. Modelos que fueron estudiados en su forma de desarrollo o ampliación respecto a la urbe que los contenía o como escenarios

${ }^{28}$ Comparativa con universidades. Universidades asfixiadas (Columbia - Nueva York, Harvard/YaleBoston). Universidades absorbidas (Roma, Atenas y Oslo) 
"ciudad" - "isla" cercanos o anexos a una urbe con mayor o menor semejanza con el modelo español que se pretendía realizar en la capital.
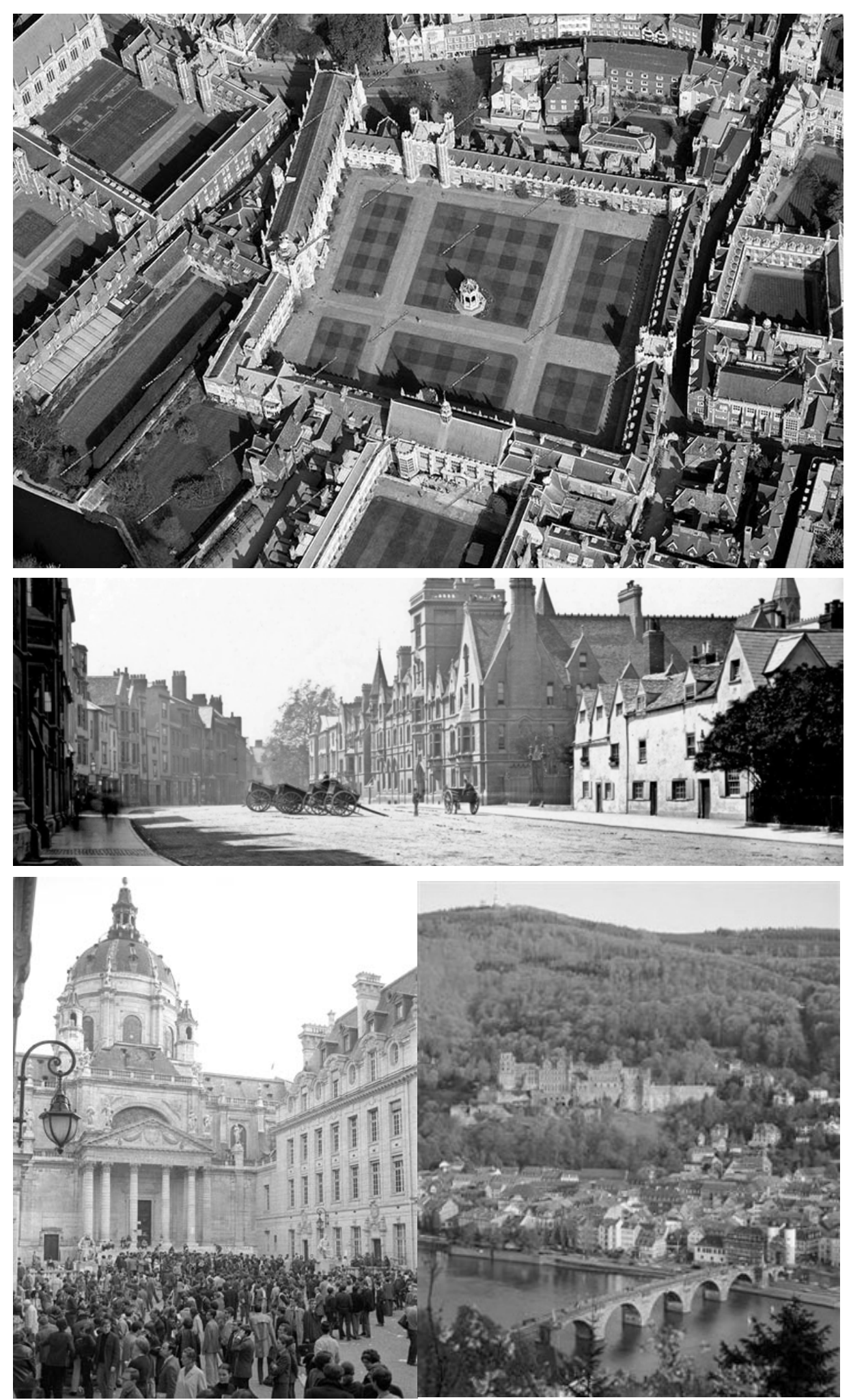

Fig. 13. Universidad Cambridge.

Fig. 14. Universidad Oxford.

Fig. 15. Universidad Sorbona y Heidelberg. 


\section{C.2.2.1_concepto de Campus en la Ciudad Universitaria de Madrid}

Según un artículo en la Revista Nacional de Arquitectura №6 de 1941 que hace referencia a todas las obras de reconstrucción que se estaban efectuando en ese momento en La Ciudad Universitaria, en 1938 la Sociedad de Arquitectos de la República Argentina editó un documento sobre la "Ciudad Universitarias de Buenos Aires", en la que se dedicaría una gran cantidad de dinero público para la edificación de una zona universitaria, solicitando al gobierno de aquella época el inicio de su diseño. En dicho documento se nombra las palabras "Ciudad Universitaria" como "una agrupación racional de elementos en uno todo armónico, para llegar a conseguir integridad en la intelectual, salud y moral, armonía en el vivir y la cordialidad en la relación, lo que permitía la realización del tipo cabal universitario" 29 .

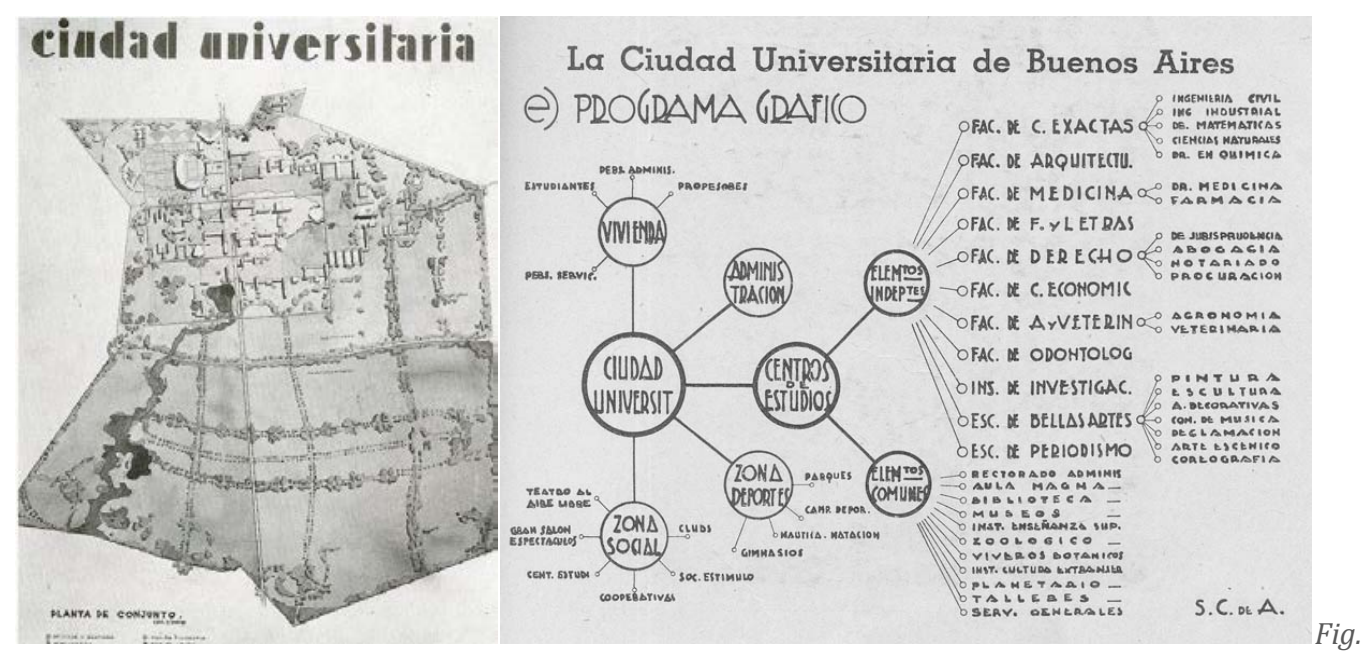

Fig. 16. Ciudad Universitaria de Buenos Aires en Argentina.1959 Planta. RNA no6

Fig. 17. Esquema general de zonificación de Ciudad Universitaria de Argentina. RNA no6

Esta Junta ha realizado toda clase de estudios, llegando a la conclusión, confeccionados los planos de la futura ciudad universitaria, de que ha de ser la más perfecta del mundo ${ }^{30}$

Se podría afirmar también, que el escritor de aquel extracto del artículo argentino claramente estaba haciendo referencia a la misma descripción que hicieron algunos de los autores y de los miembros de la Junta Directiva durante el diseño de la Ciudad Universitaria de Madrid años antes. Fue el término "Ciudad Universitaria" utilizado en los proyectos de los recintos docentes como el de Caracas, Buenos Aires o México , 1942-1943, 1959 y 1954 respectivamente, lo que

\footnotetext{
${ }^{29}$ Extracto de artículo de Revista Nacional de Arquitectura 1946. № 6- "Las ciudades universitarias en el Mundo" p.s/n

30 Declaración de Modesto López Otero sobre las intenciones de la Junta en la elaboración del proyecto urbanístico y arquitectónico de la Ciudad Universitaria.
} 
hacía que todos estos recintos tuvieran, además del nombre, un vínculo común que se manifiesta en su concepción formal, compositiva y arquitectónica.

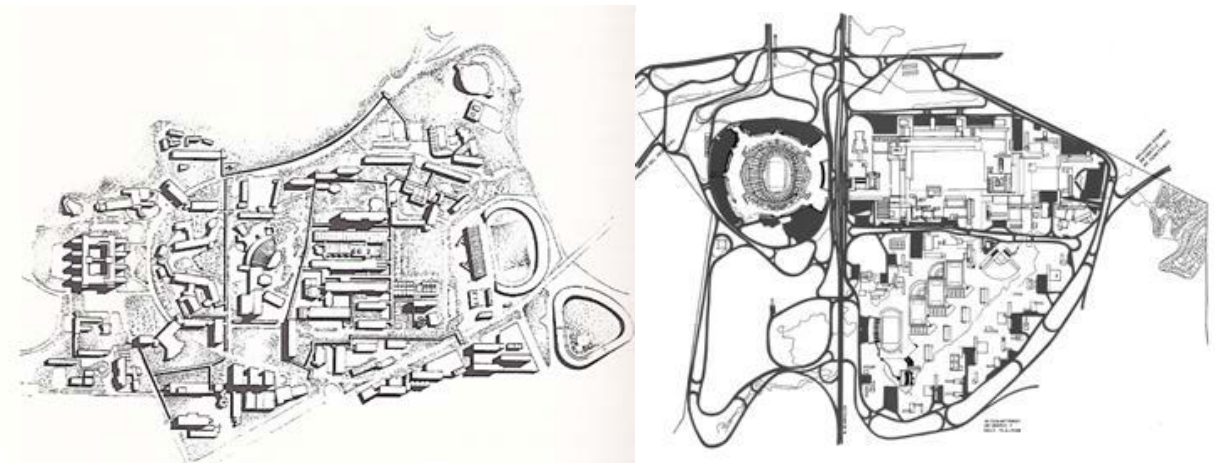

Fig. 18. Ciudades Universitaria de Caracas . La Ciudad de Saber. Ciudad y Utopía

Fig. 19. Ciudades Universitaria de México . http:www.scielo.org.co

El descubrimiento del "campus" americano como nueva forma de proyecto "urbano-espacial-arquitectónico" y los nuevos modelos vivenciales para una zona de estudiantes, supuso un hallazgo y un descubrimiento, modificando una parte del paisaje de la capital, contagiándola para siempre de espíritu universitario moderno que siempre se ha dicho que ha tenido Madrid. Se decidió que la nueva universidad tendría que ser planteada, diseñada y ejecutada, con ese modelo de ejemplo importado, a partir de todos esos conceptos estudiados en las universidades - campus que provenían de su concepción formal en planta de las traslación de los collage y quads de las universidad medievales anglosajonas. La idea o concepto espacial que se había trasformado en América dando lugar a los campus americanos de tradición anglosajona pero aplicando a las extensas superficies que allí disponían, volvía de nuevo a Europa, para volver a ser aplicada esta vez por primera vez en una universidad española.

Coetánea a la realización de proyecto universitario de Madrid, se produjo en Roma otro campus de conceptos y estrategias completamente opuestas, realizado por Piacentini. En su caso utilizó la tradición clásica de edificaciones y volúmenes entorno a un ágora o espacio central en un perímetro condensado y delimitado en manzanas. Un proyecto de mucha menor escala que el madrileño y con un sistema según su arquitecto creador, como una plaza arquitectónica y volumétricamente definida donde vuelcan creando el espacio las distinta edificaciones. Una concepción de tradición urbana de procedencia greco-romana de los foros y de los palacios del Renacimiento. Ciudad paradigma del neoclasicismo moderno. ${ }^{31}$

${ }^{31}$ Idea desarrollada por Antonio Bonet Correa en su articulo "De la Ciudad del Saber a la Isla Universitaria" . La Ciudad de Saber. Ciudad y Utopía. 1995 p. 59 
Todo lo contrario se realizó en Madrid, donde se disponía de demasiada extensión y el campus quedó delimitado, con un perímetro en torno a un espacio ciudad-isla, conectado con la ciudad, de acuerdo a la tradición americana, y cuyos edificios y arquitecturas respondieran al binomio:

\section{(Collage + Sports) Facultades y Deporte sobre un base de naturaleza}

De acuerdo también con la tradición anglosajona; pero con edificios de marcado carácter funcional y racional propio de la época, y de tradición más nacional se avanzó hacia un diseño importado y extranjero en organización y distribución de espacios pero con proyectos más tradicionales en su ejecución y materialidad. Agrupando los edificios por disciplinas, zonas o grupos, entorno a un espacio., provocando la creación de pequeños campus dentro del campus general.

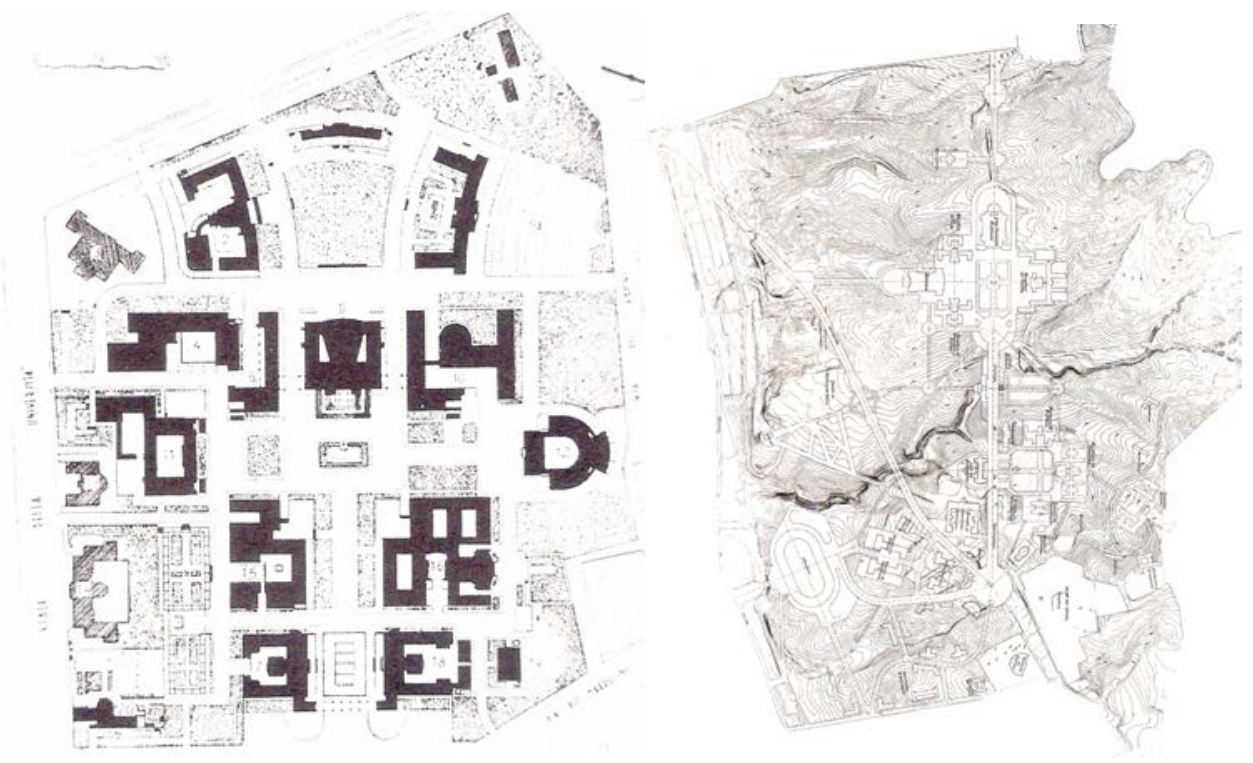

Fig. 20. Ciudades Universitaria Roma . Fuente: La Ciudad de Saber. Ciudad y Utopía. Pág. 58

Fig. 21. Ciudades Universitaria de Madrid. Plano proyecto 1929. Tesis Pilar Chías

Comparativa de composición formal de las edificaciones del conjunto a diferente escala

Ideas que fueron bastante bien acogidas entre los intelectuales de la época que solicitaban una mejora de la enseñanza profesional y de investigación, a las que se les sumaría la importancia del entorno o cambio de modelo espacial en que se realizan los estudios, la educación física, la formación espiritual y la vida en sí. Lo importante era el estudiante y su entorno.

Para ello se escogió un lugar idílico (la zona de la Moncloa), se programó un proyecto de relaciones y espacios bajo la idea clara de unidad (modelo importado de campus), pero sin tener en cuenta la escala y el impacto visual del proyecto (mas de 320Ha).Es llamativo que a la vez que se habla de la "unidad del conjunto", 
este concepto se enfrenta a la heterogeneidad de modelos e influencia de su concepción y a la heterogeneidad de estilos de los arquitectos que llevarían a cabo el proyecto urbanístico y arquitectónico

¿Es realmente la Ciudad Universitaria de Madrid un proyecto unitario?

¿Es heterogéneo o es híbrido?

En los campus norteamericanos, esta unidad se marcaba como un objetivo principal en la formación integral y completa de sus alumnos, tanto física, intelectual, moral, espiritual o religiosa pero también aplicándolo en la zona de influencia, recinto o perímetro como lugar espacial y físico dentro del desarrollo urbano de dicho campus. El propósito que se tenía era adecuar y apoyar todo un entorno y espacio físico único para cumplir dichos objetivos humanistas. Una nueva forma de vida unitaria que se estrenaría en Europa en la universidad de Madrid. El "campus", una palabra casi no utilizada en Europa, y menos en España, excepto en algún documento aislado, se convertiría en el gran descubrimiento de los cuatro miembros de la Junta constructora que hicieron el viaje, y que conocerían su aplicación en la selección de universidades visitadas. De cada una de ella se extrajo unos conceptos espaciales y urbanos que se destacarían entre el resto para más tarde mezclar, elegir y escoger entre todos ellos las ideas proyectuales generadores del proyecto que se desarrollaría.

Así, retomando la idea de "Campus" americano, como idea base que daría respuesta a las necesidades programáticas y de servicios necesarios, siendo sus concepciones formales el punto de partida en el diseño urbano y arquitectónico del recinto, no hay que olvidar que el campus respondía a unas condiciones extranjeras que se alejaban mucho de las realidades sociales-económicas españolas. Era una traducción espacial de principios selectivos, segregadores y

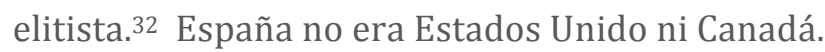

Otro error más que no siendo de diseño y concepción formal, influyó quizá también en el desarrollo global del recinto. El estudio se basaría no solo en el funcionamiento didáctico, administrativo y forma de vida sino mas bien su emplazamiento, urbanismo, composición, servicios, agrupación y relación de los edificios y todos los aspectos relacionados con la construcción.

En resumen, se buscó una idea motriz generadora, un modelo formal y espacial, que diera garantías de que el modelo adoptado era el más idóneo pudiendo funcionar de manera casi perfecta. Citando la anterior orientación doctrinal, de

${ }^{32}$ Chías Navarro, Pilar. Tesis. La Ciudad Universitaria de Madrid. Planeamiento y Realización ETSAM 1983 p. 62 
vida y sumando las pautas configurativas que habría que exportar en la concepción formal de la universidad como zona física y espacial delimitada, quedaría claramente definida, por el sumatorio de ambas a diferentes escalas:

- El carácter general de la universidad con la capacidad de abstraerse del entorno de la ciudad como "isla-ciudad" del saber o del conocimiento.

- La base del primer "campus" europeo como la idea filantrópica y elitista de un campus americano.

- Un entorno paisajístico que uniera la idea de parque y universidad. La mayor perspectiva visual y paisajística en el eje axial principal hacia un modo de eje escenográfico.

- Los elementos, construcciones jerárquicas y monumentales como hitos, ejes y tramas ortogonales como orden subyacente con un crecimiento gradual del espacio concatenado a partir del eje principal pero con sentido de globalidad.

- La construcción de elementos nuevos que se organizaban a modo de agrupaciones irregulares articuladas y concatenadas por medio de secuencias visuales de llenos y vacíos de paso entre los diferentes campus, sub-campus o quads.

- Las ideas de carácter monumental, unidad, composición, ejes generadores directores, perspectivas visuales, patios, paseos y bulevares, comunicación y ordenación, bajo una base con cierta asimetría y orden jerarquizado.

- El binomio ingles de "Collages + Sports". Los "collages" de estilo colonial se traducirían en zonas o grupos por temáticas y disciplinas en los subcampus. La naturaleza y los deportes "sports" como compañera de las construcciones en los espacios de comunicación y transición.

- Los espacios regulares abiertos y cerrados de los "Quads".

- La unión de la docencia con el sistema médico, con una nueva tipología y elementos configuradores del hospital en la zona anexa a la ciudad pero con acceso a la universidad por el lado docente. Los sistemas germanos basados en seminarios y laboratorios.

NOTA: VER Anexo CUADRO II: Recintos universitarios 


\section{C.2.2.2_ISLA DEL SILENCIO Y DEL SABER}

La profunda relación entre la universidad y la ciudad se puede definir como la clara integración de la institución social universitaria y el territorio donde se desarrolla o se sustenta. Es lo que comúnmente llamamos "vida universitaria". Esta idea de vida, relacionando la persona, el saber y la institución de la universidad, queda plasmada en el libro "An Oxford University Chest" escrito por el poeta Sir John Betjeman ${ }^{33}$. La idea de vida universitaria también queda reflejada en el proyecto urbano y arquitectónico, ya que no puede vivir la una sin la otra.

\section{UNIVERSIDAD(Institución)_Estudios+ Vida _ Collage+ Spots}

- Collage_Aulas+ Residencias+Zonas de Relación

- Sports__ Deporte+Zonas naturaleza

Un nuevo concepto universitario desconocido hasta ahora en Europa y que se impondría por primera vez en Madrid, con influencias de :

- La universidad inglesa_Educación ciudadana del estudiante.

- La universidad francesa_Educación orientada al enciclopedismo.

- La universidad alemana_ Educación de las ciencias por medio de clases prácticas en seminarios y laboratorios.

- La universidad española_ Hasta ahora de clara influencia francesa, cambiaría hacia un modelo más norteamericano (en trazado urbano) conjugando la tradición inglesa (estilo de vida del estudiante) con la investigación alemana (forma y carácter de los edificios y construcciones).

Un tipo de estudios y de enseñanza, como diría el filósofo Alfredo Lledó, sobre el saber y el pensar de su libro "La educación hace al alma navegable"34. Una zona de soledad y alejamiento de la gran ciudad, donde el estudiar necesitaba de sitios adecuados para recoger el conocimiento, y de espacios amplios y verdes a modo de paseo o retiro para fijar esos cocimientos en los tiempos libres.

\footnotetext{
33 Sir John Betjeman Poeta que escribió An Oxford University Chest en 1938 y reeditado en 1979 que describe la antigua y nueva ciudad de Oxford, su vida, costumbres y su organización interna, tanto funcional como arquitectónicamente. Esta relación profunda sobre el tema universitario, conllevaría un amplio estudio de lo urbano, sociológico, arquitectónico y tipológico en relación con la forma de vida y las relacionares de estos lugares de docencia con su entorno.

${ }^{34}$ Documental "Voces y Formas de la Memoria". La Ciudad Universitaria de Madrid (1927-2006) 1parte. Extracto de frase literal publicado en Magia y Maravilla del Lenguaje, el poder de la palabra del niño al adulto.
} 
Un lugar donde la arquitectura en el lugar tenía que dar respuesta a unas necesidades, ideas y ampliación hacia el futuro.

Con el proyecto de la Ciudad Universitaria se intentaría responder a los mismos ideales de la universidad moderna alemana que Guillermo de Humboldt fundó en 1910 en Berlín, basándose en los principios de:

- Libertad y soledad de los estudiantes.

- Colaboración de los estudiantes con los profesores en los laboratorios. 35

Por tanto, si entre todos los ideales, análisis y conocimientos previos en que se basó la nueva universidad de Madrid, se tuvieran que definir las bases formales e ideológicas, cinco ideas claras serían a destacables:

- Localización - Aire, vistas y viales como buena comunicación.

- Sociabilización - Conocimiento recíproco entre materias/disciplinas.

- Vida universitaria - Estudio-Silencio. Libertad-Soledad.

- Edificios adecuados - Clases-Seminarios y Laboratorios.

- Espacios Verdes - Parques y Zonas de deporte.

La creación de una "Microciudad", cuya apariencia fuera, a la vez urbana y campestre, pero que careciera a la vez de los problemas respectivos ${ }^{36}$

El conjunto, por el carácter natural del lugar escogido para su implantación, debía responder a una imagen de "Universidad - Ciudad" dentro de un gran parque diseñado, parcialmente boscoso y con espacios libres intentando mantener lo máximo posible la orografía y la topografía de la finca (cosa que por supuesto solo se consiguió en parte). Una zona de transición, una isla, entre la ciudad y el final de la urbe, que debería ser un ente independiente u "organismo viviente" alejado de la ciudad para darle independencia ${ }^{37}$.El alejamiento de locales comerciales, negocios, bancos hizo que la universidad se separase de la especulación capitalista, pero también de ser de alguna manera un foco en sí de vida, que no fuera la docente o la estudiantil38. Una acrópolis sin un perímetro físico y material, pero como una isla del silencio y saber en lo que constituía la periferia de la capital.

\footnotetext{
35 Frente a la universidad pragmática de solo estudiar para la búsqueda de un trabajo futuro.

${ }^{36}$ Chías Navarro, Pilar. Tesis. La Ciudad Universitaria de Madrid. Planeamiento y Realización. ETSAM 1983. P. 62.

${ }^{37}$ En referencia a la isla del silencio que se ha explicado en el epígrafe anterior.

38 Nota explicativa del autor: Comprobable es como la Ciudad Universitaria de Madrid en fines de semana y épocas fuera el calendario académico de clases, queda solitaria y vacía. De igual modo solo una pequeña sucursal de banco y algunos cajeros están en usos en determinadas facultades. No hay locales comerciales ni comercios ni negocios que no estén administrativamente y legalmente 
La coherencia y la unidad de diseño serían, como dijo López Otero, tanto a nivel urbanístico como arquitectónico, la mejor manera de diferenciarse de la heterogeneidad morfológica y funcional de la gran ciudad próxima, y así elevar la independencia y la personalidad de la universidad. Era preciso, como diría Pilar Chías en su tesis, reinventar el concepto de campus norteamericano como modelo teórico de ciudad, pero con enfoque español, "reinventarlo" en función de los condicionantes del terreno y de las capacidades técnicas de la junta o los medios constructivos.

En el caso concreto del recinto de Madrid, se escogió el lugar como zona independiente natural para la localizaciones de sus edificaciones, pero creando un cinturón verde exterior de suelo no urbanizable como aislamiento de la ciudad; así ésta no llegaría a asfixiarla, sin embargo, se mantendría un contacto mediante las vías de comunicación con el centro de la urbe, ya que éste era necesario y conveniente para el funcionamiento y actividad de la nueva "ciudad". Esta relación que se estableció tan necesaria y conveniente, se interpretó quizá de manera errónea como veremos durante los procesos de génesis en este mismo capítulo (c.4). Error de conexión que se mantuvo y no se modificó en ningún momento de su conformación, ni de manera posterior manteniéndose hasta la actualidad. Esto les hizo plantearse la búsqueda de nuevas soluciones de diseño y proyecto. Identidad y espíritu en un mismo lugar. Un ejemplo de donde copiar.

La franja urbana que conectaba la universidad con la capital era un filtro de zonas verdes o servicios que separaba la zona de edificaciones universitarias de las edificaciones residenciales y de vivienda del límite de los barrios de Arguelles y la zona de la colonia metropolitana. El Hospital Clínico era la única edificación de la universidad con uso y entrada a ambos lados, y el Parque del Oeste funcionaba como un gran espacio verde y de transición, siendo el inicio del límite de las facultades.

Una gran masa arbórea que hacía de transición, pero ésta era buscada y consentida. El espacio del asilo, se impuso de manera obligada en el diseño. El Parque del Oeste fue un punto de apoyo como gradación y metamorfosis entre la ciudad y la universidad 39.

vinculados con alguna universidad. Esto se ha mantenido así desde los comienzos en los años treinta hasta la actualidad.

${ }^{39}$ La zona del Asilo de Santa Cristina, sin embargo, siempre fue el objeto a salvar en el proyecto, un punto negativo ya que el intento de expropiación no se consiguió y toda la ordenación, ejes o zonificación se realizar entorno a esta "bolsa" que separaba a la universidad de la urbe. 
El campus funciona como un ente autónomo, uniéndose a la capital por una sola vía a modo de cordón umbilical. Es por tanto un elemento aislado de la ciudad. Seguramente por la idea de hacerla un espacio del saber lejano y tranquilo con idea de ensimismamiento para el estudio y la investigación; un "Espacio del Saber" como un ente separado de la ciudad, pero conectada sutilmente. Un entorno independiente del entorno urbano pero, desarrollando una de sus dualidades:

- Entre campus de acuerdo al modelo americano: Organización, unitario, aislamiento, residencia, construcción para la docencia y espacios libres.

- El campus de acuerdo al modelo europeo: Tradición, armonización, relación de la universidad con la ciudad.

Pero no hay que olvidar que la intención de base, no era aplicar modelos innovadores sin razón, sino realizar una nueva universidad acorde a los tiempos modernos y a las nuevas formas de enseñanza, utilizando la mezcla de las mejores solucione formales y compositivas como respuesta.

Ideas proyectuales de formalización y organización fueron copiadas de estas universidades de origen americano e inglés, al vivir y comprobar in situ, la organización de la vida universitaria. Pero aparte de la idea generadora y organizadora del proyecto en sí, se dieron cuenta de la importancia social de varios conceptos que plasmarían en el proyecto de arquitectura y urbano. 


\section{C2.3_ Planeamiento de un proyecto a diferente escala}

... los edificios universitarios son viejos en inadecuados comparados con los que he visto en otros países. Me han dicho que ustedes los arquitectos tienen una escuela impropia de su misión... Yo he pensado en la necesidad de emprender la construcción de los edificios de una gran universidad que no fuera solo nacional, sino hispanoamericana.... Ya sé que todo esto es económicamente difícil para nuestro Estado, pero se puede organizar con el tiempo, según un plan bien organizado...40

Las obras comenzaron en diciembre de 1928 en una extensión de 320Hac., obtenidas de fincas y terrenos, y sin ser todavía el Ministerio de Instrucción Pública dueño del terreno41.Proyectistas, diseñadores, usuarios y profesores fueron consultados sobre las ventajas y los inconvenientes de cada uno de los sistemas de diferente tamaño en cada recinto visitado durante el viaje. Ya que la gran extensión, seguramente preocupaba, al igual que la relación del costo de la universidad y su posterior mantenimiento. 42

La idea de aglutinar, de acuerdo al modelo de campus americano, todo en un recinto, se difuminó en la aplicación de la escala del proyecto. Quizá poseer tanta extensión para proyectar no tuvo tantas ventajas como se pudiese pensar, y sí más inconvenientes. Al estirar, en el eje norte, el trazado manteniendo el espacio verde de parque-bosque de comunicación, no se tuvo en cuenta que los cuatro núcleos o zonificaciones, los "sub-campus", adoptaron más el uso de plazas o zonas de relación entre ellos y no con el resto de disciplinas, como se quería desde el primer momento. La unidad y vida la relación entre espacios se ponía en juego.

Lo que está claro es que su localización en la zona norte era lo que más beneficiaba al proyecto. Los aires limpios de la sierra y su cercanía-cierre entre con dos grandes masas verdes la protegían: El Pardo y la Casa de Campo. Esa cercanía física y la buena comunicación, por medio de una gran avenida que la atravesaba en continuidad desarrollaron el programa de edificación y de zonas verdes estudiando las condiciones ideales de emplazamiento, accesibilidad y comunicación. Una zona delimitada pero con posibilidad de ampliación y con un marcado carácter de ciudad jardín rodeada de parques o zonas verdes que la aislaran pero sin perder la relación directa con una de las zonas más habitadas de la urbe. ¿Pero se consideró adecuadamente la escala del proyecto?.

\footnotetext{
40 Conversación entre el Rey y López Otero, según la conferencia pronunciada el 22 abril de 1939 en el Colegio Oficial de Arquitectos de Santander

${ }^{41}$ Hecho que sucederá con la promulgación del Real Decreto de 3 Diciembre de 1928.

42 Ideas basadas en la variedad de universidades visitadas de diferentes tipologías, pero la mayoría de extensos terrenos y algunas en proceso de proyecto o construcción poco avanzado.
} 


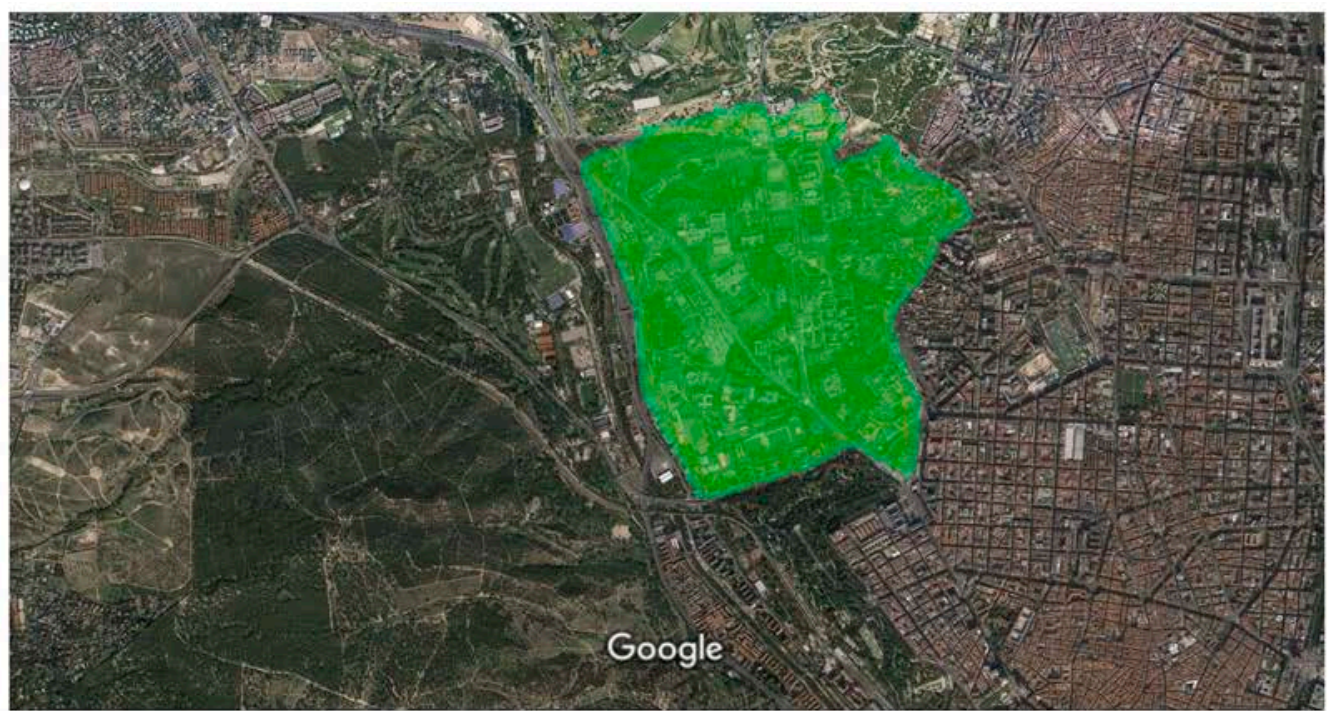

Imágenes @2015 Cnes/Spot Image,DigitalGlobe,Datos del mapa @2015 Google,Inst. Geogr. Nacional $200 \mathrm{~m}$

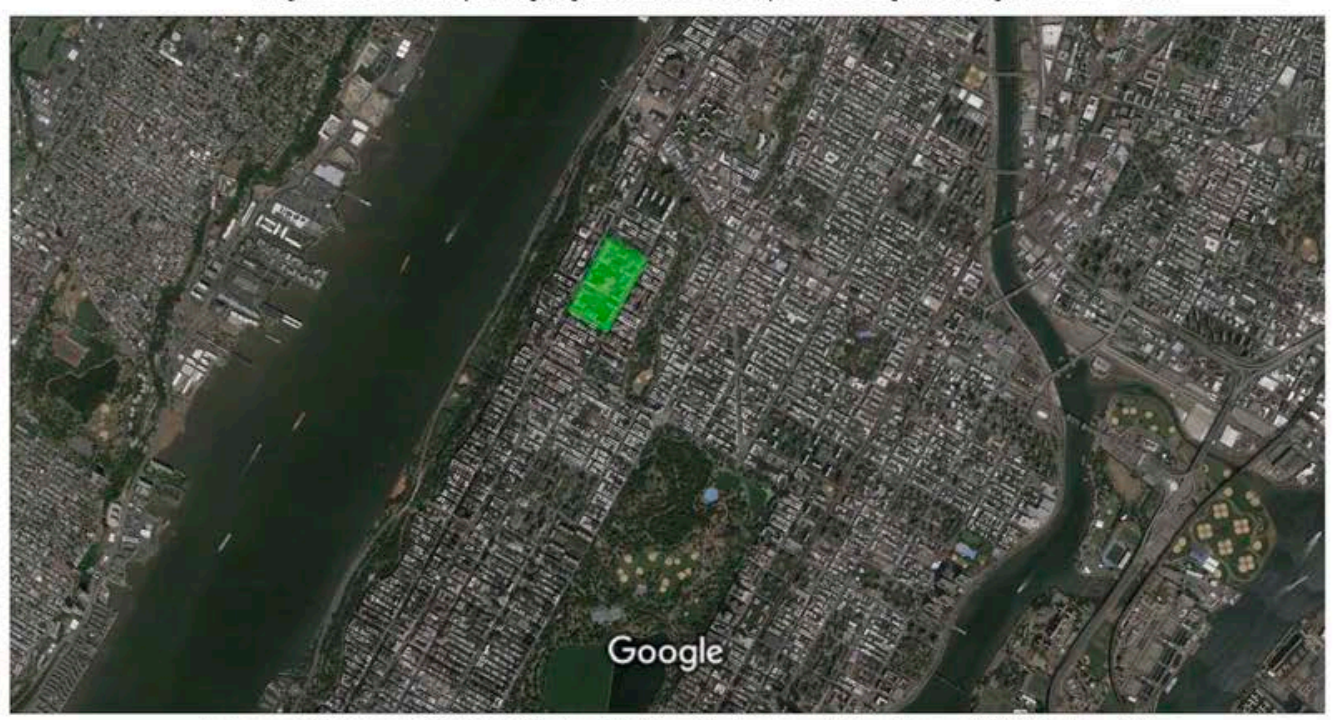

Imágenes ๑2015 Bluesky,DigitalGlobe,Sanborn,USDA Farm Service Agency,Datos del mapa @2015 Google $200 \mathrm{~m}$

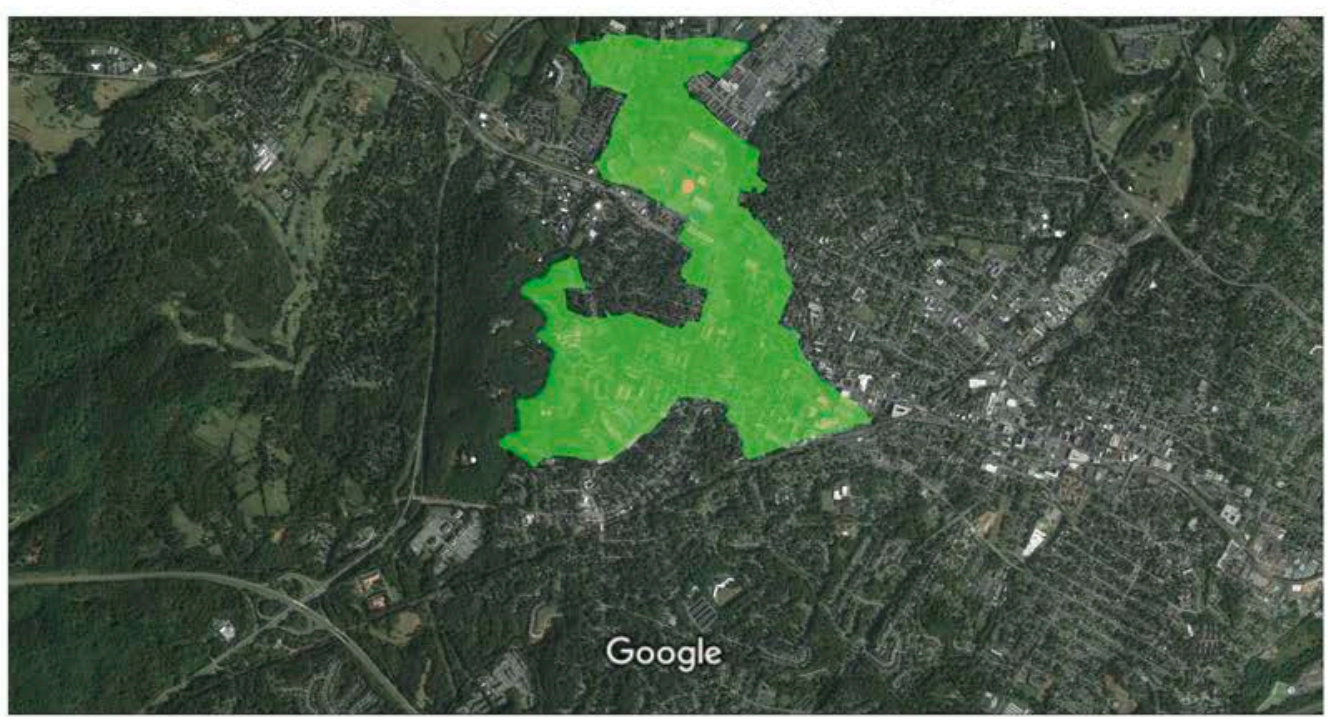

Imágenes 2015 Commonwealth of Virginia,DigitalGlobe,USDA Farm Service Agency,Datos del mapa $\odot 2015$ Google $200 \mathrm{~m}$ L

Fig. 22. Imagen comparativa sobre base cartográfica GOOGLE Map, de los campus de Ciudad Universitaria de Madrid, la Universidad de Columbia de Nueva York y la Universidad de Jefferson de Virginia en Baltimore. 


\section{C.2.3.1_Composición Urbana y Planimetría}

La primera decisión del proyecto fue la planimetría y la composición urbana en función del programa en zonificación o grupos por disciplinas que tendrían que quedar comunicadas y relacionadas por viales; lo segundo sería la ubicación en el terreno extenso pero delimitado, de las zonas intentando igualar la cota, por lo que se realizaron plataformas por medio de movimientos de tierras y desmontes; esto se consiguió con eje longitudinal ordenador en función de la pendiente, y lo tercero sería su relación con la ciudad de manera gradual, anexa e independiente a ella pero mediante una zona de transición y bisagra que la siguiera vinculando tanto física como visualmente con la ciudad.

Pero todas estas decisiones, tan drásticas y ordenadas, no eran fruto de una conjunción de idea de todos los arquitectos de la Junta. Ni fueron la idea clara y simple de Modesto López Otero con conocimientos previos clásicos y todas sus experiencias previas constructivas en la capital. No fue una casualidad ni una imposición de las condiciones del terreno que hacían esa solución única posible...

Cada decisión, idea o trazo sobre el papel, tanto del proyecto como de las edificaciones fueron fruto quizá, a mi modo de ver, de la confluencia de dos hechos importantes y decisivos:

- La adecuación de la mejor idea que habían conocido en el extranjero, en concreto de la vida universitaria americana, intentando utilizar y controlar la mayor extensión posible de la que disponía colonizando el espacio.

- El saber y el rigor de realizar una serie de edificios bajo la idea común de favorecer el conjunto, y la humildad de cada arquitecto que no quisieron que cada una de su obra fuera un objeto individual con identidad propia.

\section{Lugar(Suelo) + Urbanísimo/Arquitectura (Procesos Proyecto)_CONJUNTO}

Siendo un proyecto en planta que se presenta como unitario y extensivo, intenta abarcar lo máximo del perímetro establecido. Se plantea, por un lado, un proyecto horizontal y disperso, pero cono una ley general organizadora del conjunto.

Las imágenes que se realizan asemejan a los campus americanos y canadienses que se representan claramente con elementos-hitos que conforman la espina dorsal que era el paraninfo; concentrando la fuerza visual y carácter representativo en el eje ordenador, en la extensión y en carácter unitario independiente. 


\section{Grupos de zonificación- ORGANOS}

Si analizamos de manera abstracta el conjunto, mirando o analizando el proyecto "en planta", comprobamos que en gran parte el proyecto SI se intentaba adaptar a la topografía, ya que la disposición del eje de la avenida, se colocó de manera extensiva y con la dirección que menos inclinación produjera en el vial; permitida por el hueco que permitían los "solares intocables" existentes previos. Estructurando una zona simétrica y ordenada en la zona norte, a modo de "cabeza"; una pieza longitudinal que estructura a un solo lado el grupo médico 43 ,a modo de "columna vertebral" con el gran vacío como "corazón", y una zona más disgregada, aleatoria y orgánica conformando el Grupo de Bellas Artes y Deportes, a modo de extremidades y pies.

Fueron los cuatro grupos o campus de disciplinas, y la idea de abarcar todo el mayor ámbito posible, lo que generó la distribución de los campus:

\section{ARQUITECTURA_Estudios}

- CABEZA_ Grupo general, más amplio formado por el Paraninfo, Rectorado y la Biblioteca unidos a Filosofía, Ciencias y Derecho - La cabeza de la universidad, al final del eje generador de la estructura

- COLUMNA/CORAZON_ Grupo Médico formado por Medicina, Farmacia y Odontología; relacionándose entre sí y en especial Medicina con el Hospital Clínico, conectándose éste con acceso público independiente a la ciudad.

- PIES_ Grupo de Bellas Artes, que estaba compuesto por la Escuela de Arquitectura, Pintura, Escultura y Grabado, además del conservatorio de Música y Declamación

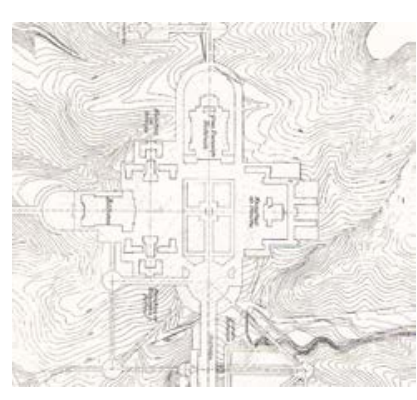

Fig.23. Grupo General

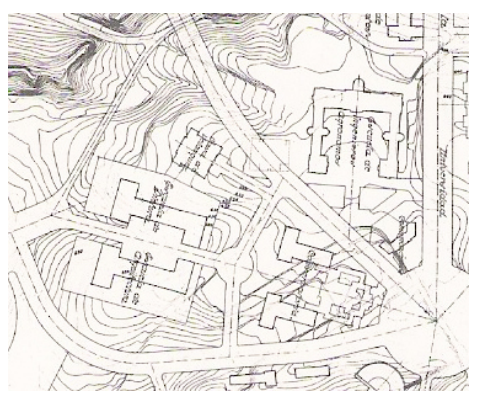

Fig. 25. Grupo Bellas Artes

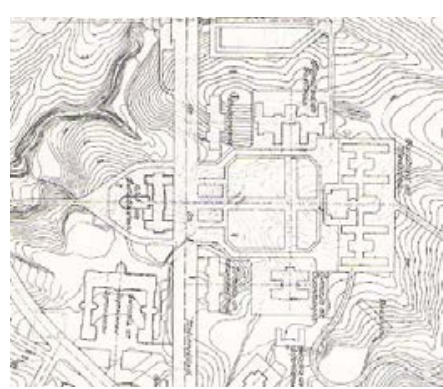

Fig. 24. Grupo Medico

Imágenes parciales de zonificaciones o grupos del Primer Proyecto-Ideal 1928

\footnotetext{
43 Quizá a modo de cornista, mirando al paisaje de la sierra de Madrid por el momento no se pensó en la colocación de su simétrica si no fuera estrictamente necesario. 
Los principales núcleos tienen a su vez una ordenación propia, con ejes normales entre sí, dando lugar a un espacio interno, cuadrado o rectangular ${ }^{44}$.

\section{ESPACIOS DE RELACION_Vida}

- Grupo de Residencias y Deporte, con campos de juego y zonas verdes. Continúas, anexas a las otras, con capacidad para dar cabida a un gran número de estudiantes.

- Grupo de edificios complementarios: comedores, residencias de profesores, centros de comunicación, y el gran Templo de la Universitaria.
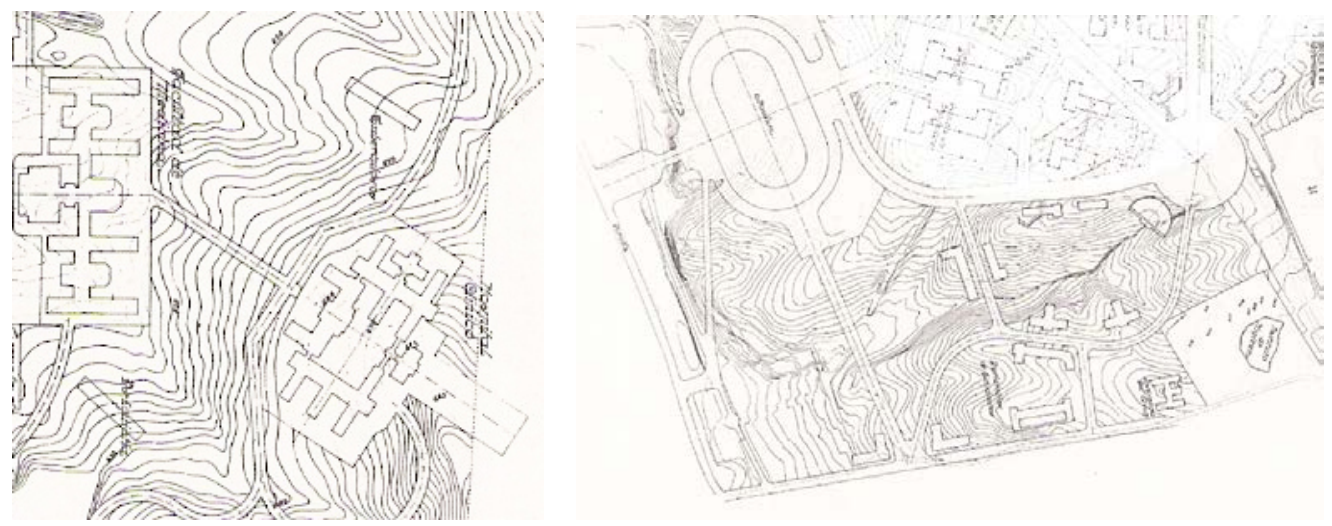

Fig. 26 y 27 Zonas de relación Grupo Medico y Zona de Deportes-Edificios Complementarios Imágenes parciales de zonificaciones o grupos del Primer Proyecto-Ideal 1928

\section{Viales- ARTERIAS}

En un emplazamiento paisajístico con una topografía tan acusada, solares o parcelas con construcciones previas y un proyecto tan extenso y heterogéneo, el programa unitario de elementos individuales que había que distribuir ordenadamente, tenía que cumplirse con una adecuada organización de cada edificio en relación a su propio espacio y bajo una disciplina orgánica ${ }^{45}$. Una adecuación a las condiciones del entorno, contextualización formal y fluidez espacial que configuraba su jerarquía de ejes, sus zonas y la relación de estas por los viales.

\footnotetext{
44 Idea y explicación de Pablo Campos Calvo- Sotelo durante corrección

45 Los principios fundamentales de la arquitectura orgánica, disciplina constructiva caracterizada por la funcionalidad, adecuación a las condiciones climáticas del entorno, contextualización formal, y fluidez espacial.
} 
Un eje que emerge de la ciudad y se dividía en un tridente configurando:

- Eje de salida original que comunicaba Moncloa, con la Escuela de Agrónomos y el Palacete ${ }^{46}$. Esta rectilínea nueva avenida, se constituía sobre un trazado antiguo de las fincas originales, que comunicaba Moncloa con el Palacete y a continuación con El Pardo. Consecuencia de ésta fue la aparición como eje del proyecto de una segunda avenida.

- Dos ejes secundarios. Uno principal y más largo que configuraría la Av. de la Universidad, menos respetuosa con la topografía, con orientación SurNorte y de la que surgirán de manera perpendicular a ella, las calles o ramales hacia cada núcleo de edificación o núcleos del programa, y otro secundario más sinuoso que comunicaría con el Estadio y el río en la zona de deportes. Del primero a su vez se configurarían ejes menores perpendiculares con acceso a los grupos.

Los conceptos de linealidad y ortogonalidad se identificaban claramente con los de representatividad e importancia, y por conseguir estos efectos quedaban más que justificados el gasto y la intervención tecnológica ${ }^{47}$

Una mezcla de ejes y edificaciones que dio lugar a la planta de un conjunto, conjugando la mezcla de la tradición compositiva beausxartiana con el sentido de axialidad de los ejes con el monumentalismo escenográfico de la perspectiva de las edificaciones. Los conceptos de linealidad y ortogonalidad se dieron claramente en la zona de cabeza y columna del conjunto. Mientras conceptos más orgánicos o naturales de escalonamiento en pendiente, por la topografía del terreno, organizaron la parte que se podría llamar, continuando la terminología anatómica, pies o extremidades.

La separación y distancia entre las edificaciones del conjunto de cada zona no favorecieron sin embargo la mejora del estudio interdisciplinar, la relación entre los espacios de los grupos/zonas que se pretendía. Ya que incluso estando adecuadamente dispersos y a la vez conectados, los espacios entre ellos, no fueron capaces de generar y organizar a la vez la unidad del conjunto. Toda una serie de conceptos de espacialidad y relación que se pueden entender desde una escala más lejana o urbana, a una escalas mas cercana y arquitectónica. La subdivisión, a pesar del orden, hacía desaparecer en parte la idea de unidad o coherencia entre

\footnotetext{
${ }^{46}$ Nunca se pensó que este eje tomaría más tarde tanta importancia y tráfico hasta convertirse en la salida norte de la ciudad. La salida a la carretera de la Coruña era un pequeño vial que discurría lateral al rio Manzanares y empezaba en la zona de la Moncloa y se comunicaba por el Paseo Moret. 47 Chías Navarro, Pilar. Tesis. La Ciudad Universitaria de Madrid. Planeamiento y Realización. ETSAM 1983. p.70 
las zonas que tanto se pretendía, a favor de un espacio mas individual y de relación interna consigo mismo, pero no de manera colectiva con los del resto del campus

Al igual que las inquietudes de Leonardo eran establecer el canon perfecto del cuerpo humano, relacionándolo con las formas geométricas más simples y perfectas, por la correspondencia de sus partes con el todo y entre sí, en un cuerpo ideal. Haciendo una traslación, el trazado de la vías y ramales, tendría que ser similar. Idea original y previa de ser concebida de una manera unitaria y no por edificios puntuales. Una relación de sus partes (edificios) con el todo (Campus)
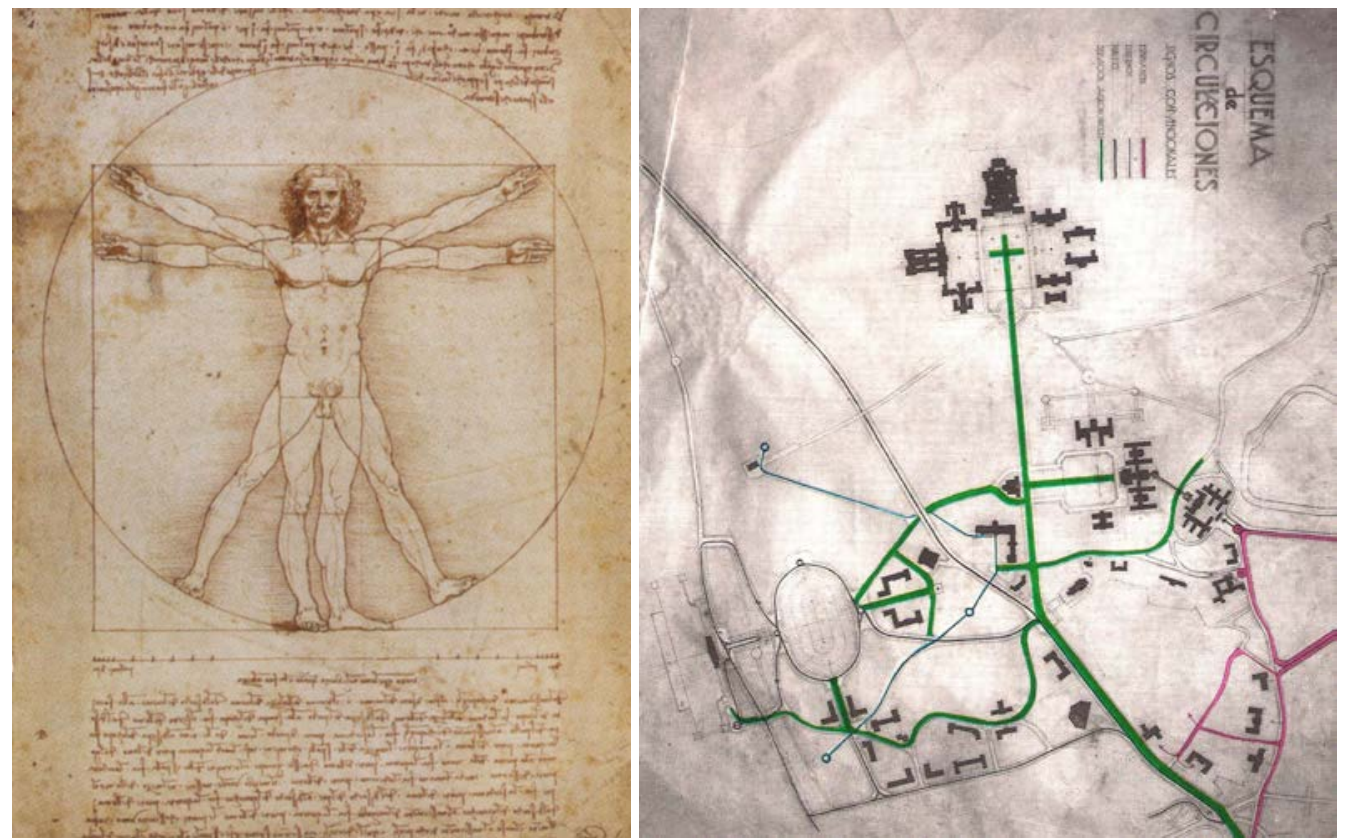

Fig. 28 y 29. "Esquema de las proporciones del cuerpo humano" ( conocido por "Homo Cuadratus" u "Hombre de Vitruvio") Imágenes de Esquema de Circulaciones. Proyecto1928 

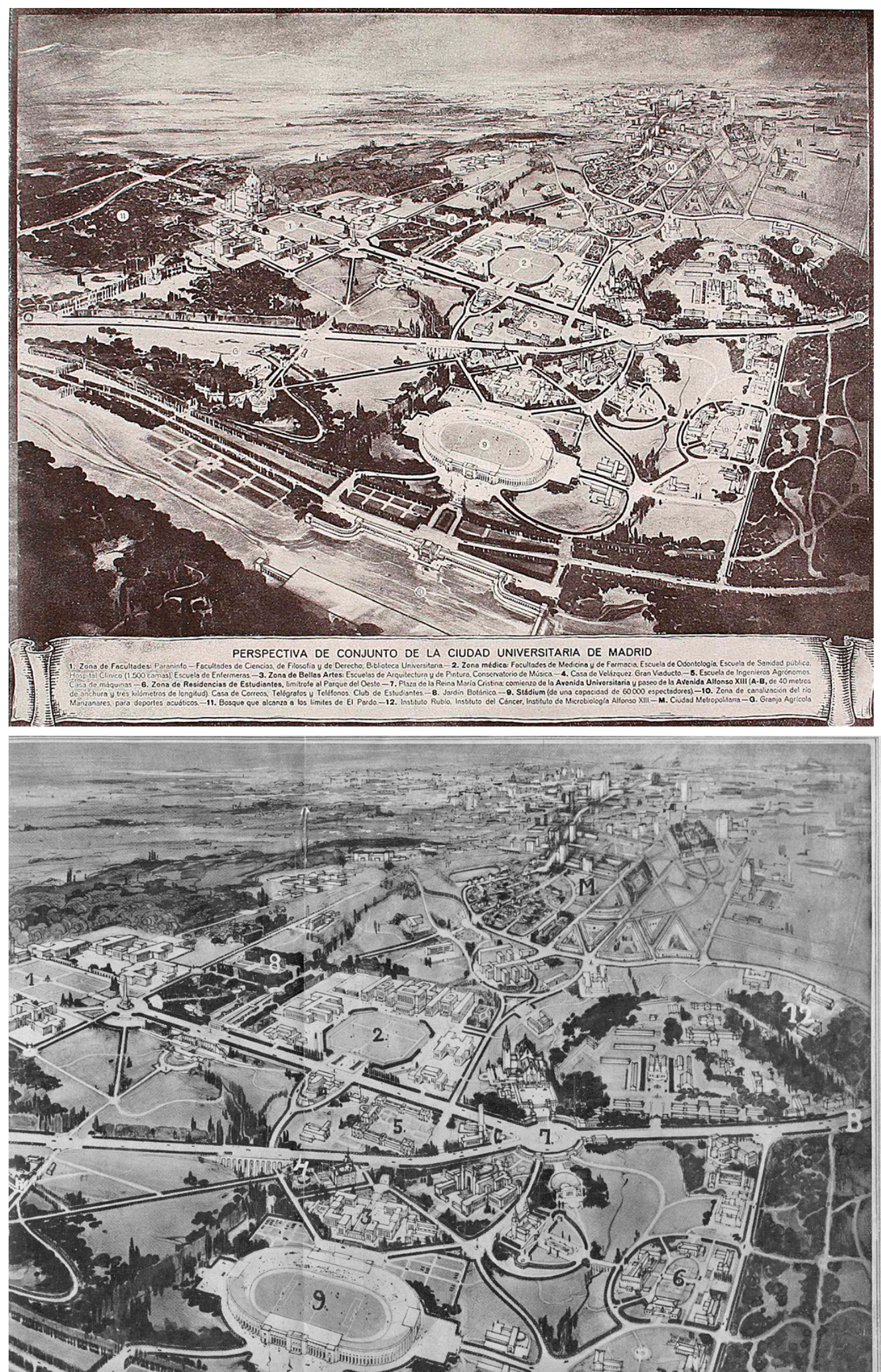

Fig. 30. Perspectivas ideales de la Ciudad Universitaria de Madrid. Diciembre 1928.

1- Zona de Facultades. 2-Zona Medica.3-Zona de Bellas Artes. 4-Casa de Velázquez y Gran Viaducto.

5-Escuela de Ingenieros Agrónomos. 6- Zona de Residencia de Estudiantes. 7- Plaza de Reina Cristina (Avda. la Universidad y de Alfonso XIII) 8-Jardín Botánico. 9- Stadium. 10- Canalización del río y deportes acuáticos. 11- Bosque. 12- Instituto Rubio, Instituto del Cáncer, Instituto de Microbiología Alfonso XII.M-Ciudad Metropolitana. G-Granja Avícola. 


\section{C.2.3.2 _PROYECTO REALIZADO POR GRUPO Y POR FASES}

\section{PRIMER PROYECTO 1928}

Tras la estrategia inicial de la elección del emplazamiento, la planificación formal, la unidad arquitectónica y la planificación, se creó un sistema con un plan por fases para realización del recinto, aglutinando una serie de grupos, sub-grupos y con posibilidad de ampliación y con una visión de un crecimiento y modificación flexible futura.

- Una $1^{a}$ fase de movimientos de tierras, creación de infraestructuras (alcantarillado, agua, calor, arbolado, y la realización de por lo menos dos edificios de cada campus o zona).

- $2^{\mathrm{a}}$ fase de edificios emblemáticos

- $\quad 3$ a fase de edificios complementarios

\section{PRIMERO PROYECTO - CORREGIDO 1929}

Durante los concursos de obras se iban introduciendo progresivamente modificaciones tanto en el proyecto general, en las edificaciones, como en la desaparición y modificación de algunas vías. La construcción de los centros de grupos se había basado en varios proyectos y tanteos que coordinaran los elementos con cambios de la topografía con adecuación de la circulación y la posibilidad de correlación o comunicación entre ellos. Entre lo más destacado:

- Los cambios en la situación y ubicación del campus de Medicina y su relación con el Clínico, que quedó prácticamente tangente y desvinculado.

- Entre la zona de Residencias y el Campus de Bellas Artes (zona orgánica al otro lado de la avenida hacia el río) apareció una nueva zona deportiva (La Vaguada del Degollado). Debido a la concesión de terrenos a nuevas residencias y realizando movimientos de tierra para la explanación de terrazas, la zona se modificó a favor del uso deportivo.

- Se realizó el primer replanteo de la zona del botánico (la vaguada del Cantarranas) entre Farmacia y Ciencias, como zona de relación entre disciplinas

\section{PRIMER PROYECTO - IDEA REPUBLICANA 193148}

Tras el cambio de gobierno, el proyecto se encontraba muy avanzado, y considerando tan trascendental y necesario, no se dudó en hacerlo propio y

${ }_{48}$ Debido al cambio de nombre que sufrieron edificios y calles al instaurarse la República tras la Monarquía, es posible encontrar los mismos lugares con nombres diferentes. En este trabajo se utilizará el nombre establecido durante la época que se esté estudiando, sirviendo así para ubicar el período cronológico en que nos encontremos 
continuar sus obras; manteniendo así a la mayoría de los arquitectos-redactores, pero simplificando el programa, cambiando algunos ejes o viales y eliminando elementos secundarios o usos más superfluos.

La construcción tenía que ser rápida y eficaz, por la necesidad de inauguraciones parciales de facultades para entrar en funcionamiento las clases de docencia cuanto antes. Una $1^{\underline{a}}$ fase de continuación de obras de la anterior directriz monárquica; una $2^{\text {a }}$ fase donde se complementarían los campus perimetrales cerrándolos con el cuarto lado, ( creando de ese manera la consolidación de los campus en espacios cerrados a modo de claustro), el avance en los equipamientos deportivos y la construcción del jardín botánico; y la $3^{a}$ fase de edificios complementarios, como el observatorio pero desapareciendo del programa el templo o parte del campus de Bellas Artes.

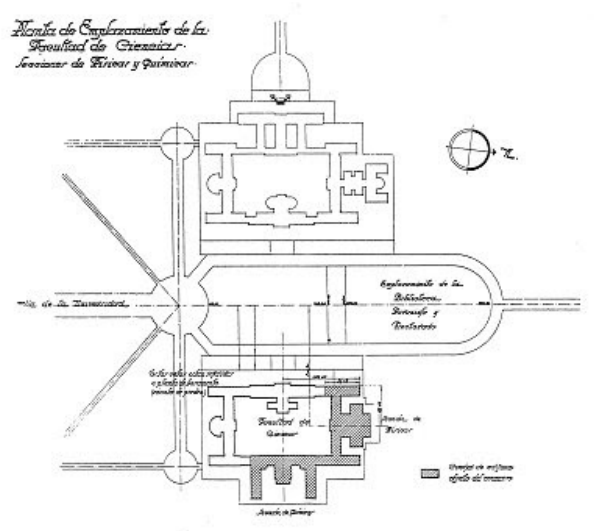

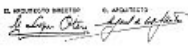

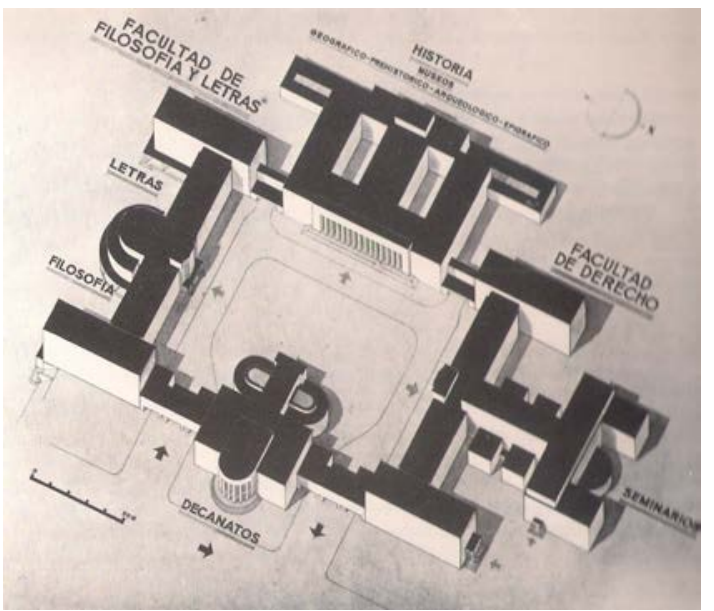

Fig. 31 y 32. Planta del Conjunto. Encabezamiento de la Facultad de Ciencias Y Proyecto del Emplazamiento general de los edificios de la zona de Letras. La CUM vol II. p. 37 y 53.

El viario seguía siendo un elemento de articulación y orden , pero se modificaron sus nombres, no así su trazado. La Av. de Alfonso XII pasaría a ser de la República, considerado como el acceso más bonito y bello de entrada y salida a la capital; y la Av. de la Universidad cobraría nueva importancia al convertirse en zona de paso rodado hacia la Dehesa la Villa

Desde el punto de vista de proyecto, durante la República se favoreció los usos realistas y quizá simplificó eliminando elementos superfluos, pero desde el punto de vista urbanístico modificó el concepto de unidad y relación al cerrar los campus y permitir el uso rodado por la mitad de la zona que estaba destinada solo a peatones y estudiantes. ( uno de los mayores y primero errores, provocando la separación de campus; creando la primera barrera física dentro del campus) 

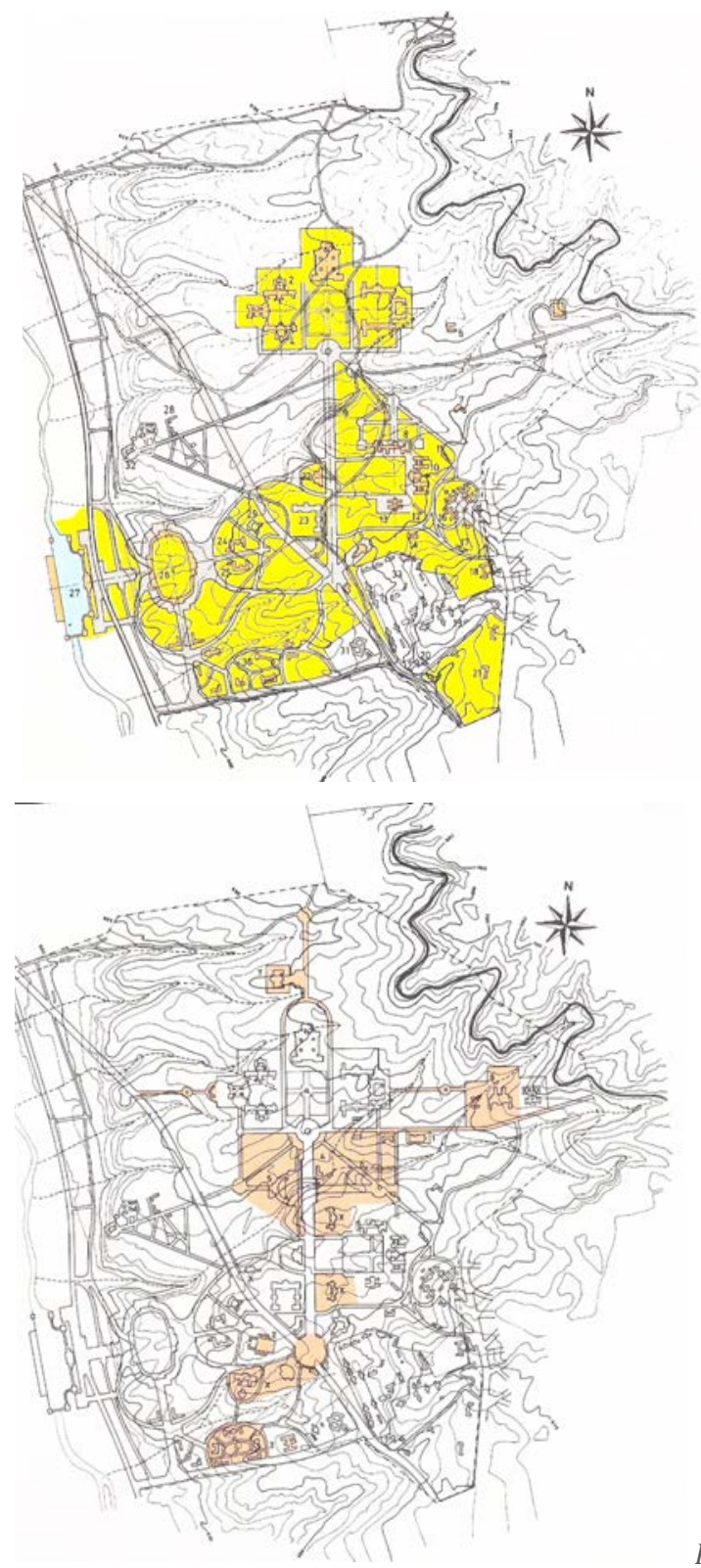

Fig. 33. Proyecto Inicial 1928 .

Fig. 34. Modificaciones 1928-1929.

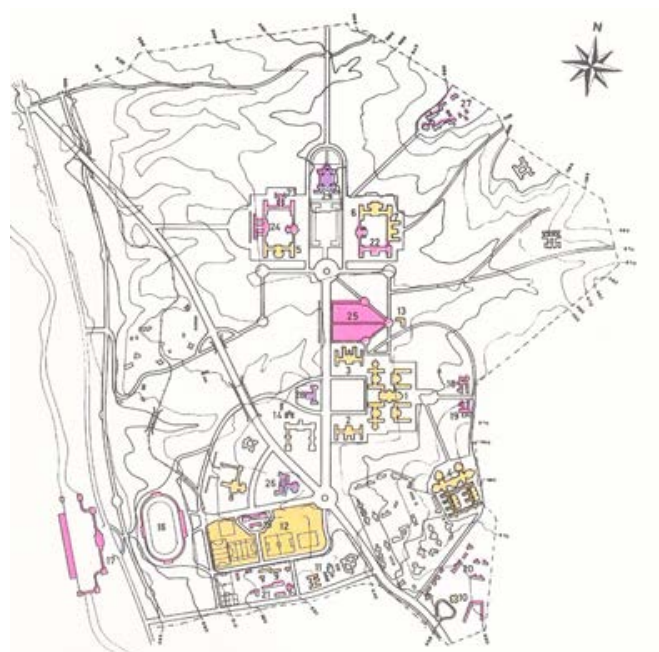

Fig. 35. Proyecto Republica 1931.

Planos tesis Pilar Chías. La Ciudad Universitaria de Madrid. Planeamiento y Realización. 1983 


\section{PRIMER PROYECTO- CONTRUIDO 1936}

Aunque se pensó en un inicio la realización de un concurso internacional, se valoró mucho que la obra pudiera ser realizada y supervisada por arquitectos españoles locales, residentes en Madrid bajo el mando y supervisión de uno como director ${ }^{49}$. Sería un proyecto de campus como un proyecto de conjunto, realizado por una serie de arquitectos heterogéneos pero arquitectos españoles que darían leyes propias a una ciudad dentro de otra.

Se aunó al final, así ejecutándose las obras, la idea de crear un imponente conjunto a base de grande ejes viarios y extensas zonas ajardinadas, con zonas o grupos ordenadas bajo un plan trazado unificador y de conexión entre las partes que se intuían que se extenderían en toda las direcciones a tratar . Los planos muestran de forma gráfica la evolución del "campus", pudiendo concretar hasta aquí a una primera etapa de génesis desde 1926 hasta 1936.

Un proyecto inicial, secuencial con modificaciones, pero un proyecto construido inconcluso. Diez años de ideas, bocetos, tanteos, proyectos y replanteos de una universidad que empezaba a materializarse en infraestructuras, construcciones, espacios de relación y un largo etcétera de elementos.

Según palabras de José Manuel Barbeito y Javier Ortega en su artículo sobre "El Edificio y su proceso de Proyecto" ${ }^{50}$, en referencia al proyecto universitario madrileño especifican que este complejo sistema ${ }^{51}$ debería de ser objeto de atención y estudio tanto de los tanteos previos a su realización, como a las causas y circunstancias de su primera concreción y conjunto de avatares ocurridos a lo larga de su ya dilatada vida materialidad.

\footnotetext{
49 Idea que se podría haber confirmado y comprobado, imitando el sistema de supervisión de la Universidad de Rochester, que se prefirió encargar a un estudio y conjunto de arquitectos noveles y con menos experiencia, pero que tenían más facilidad y rapidez en acercarse a la supervisión de las obras de campus.

50 Ideas extraídas del libro del "Edificio de Filosofía y Letras en la 2a Republica" que se complementan con las anteriores explicadas en el capítulo 1 sobre la idoneidad del lugar por otras circunstancias más estratégicas o de interés político.

${ }^{51}$ Haciendo referencia al sistema de creación, proyecto y construcción del recinto. 


\section{C.2.4_PROCESOS DE GÉNESIS}

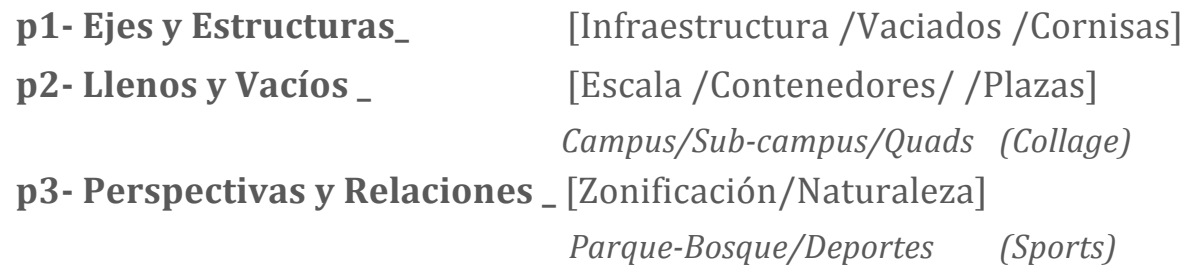

Si se hubiese proyectado en el momento actual, quizá no se hubiese dudado en hacerlo en el credo de la nueva arquitectura racionalista y funcional, pero con la modalidad más reciente, es decir dando su valor a las preocupaciones eternas que surgen del sentimiento, de lo sensible, en la actividad imaginativa del proceso, a saber, la proporción, la armonía, el sistema de ejes, el juego de masas y volúmenes y relieves con la luz, la ornamentación bien aplicada, la gracia, la belleza en fin... ${ }^{52}$

Para analizar y descubrir EL PROCESO DE CONFORMACIÓN generador del proyecto a nivel formal, físico y conceptual, había antes que conocer sus ancestros, y su desarrollo formal en el lugar concreto para así entender bajo que leyes subyacentes el proyecto se conformó. Forma y lugar son términos que remiten a términos como : (figuración, composición lenguaje) el primero y ( contexto, ambiente y preexistencia) el segundo. La invención que conlleva la "forma" y la atención que conlleva el "lugar", constituyen factores clave para impulsar una aproximación y análisis del proyecto.

Una vez entendido el origen y fuentes de la tradición arquitectónica universitaria previa, el desarrollo y la conformación del recinto urbano, podríamos definir este proceso de GÉNESIS en una seriación de capas o estratos. Un proceso de variación y aprovechamiento del espacio que cambio la finca de La Moncloa hasta la actualidad pero donde el campus proyectual original sigue encontrándose toda la base de la concepción del recinto urbano universitario original.

La concepción y realización de líneas y trazos base, de diagramas o esquemas abstractos, capaces de resumir o simplificar el proyectos a esquemas, movimientos o trasformaciones que experimenta el proyecto. Son como dispositivos o términos que reflejan los aspectos mas formales y materiales de un objeto arquitectónico. Dispositivos de procesos planteados desde la capacidad creativa, individual y subjetivo, siempre desde la mirada y posiblemente intransferibles .

52 Palabras de Modesto López Otero durante una conferencia en Santander en 1959 sobre el proyecto original y la ideación de la Ciudad Universitaria. 
Una actitud buscando la forma y una reacción frente al lugar.

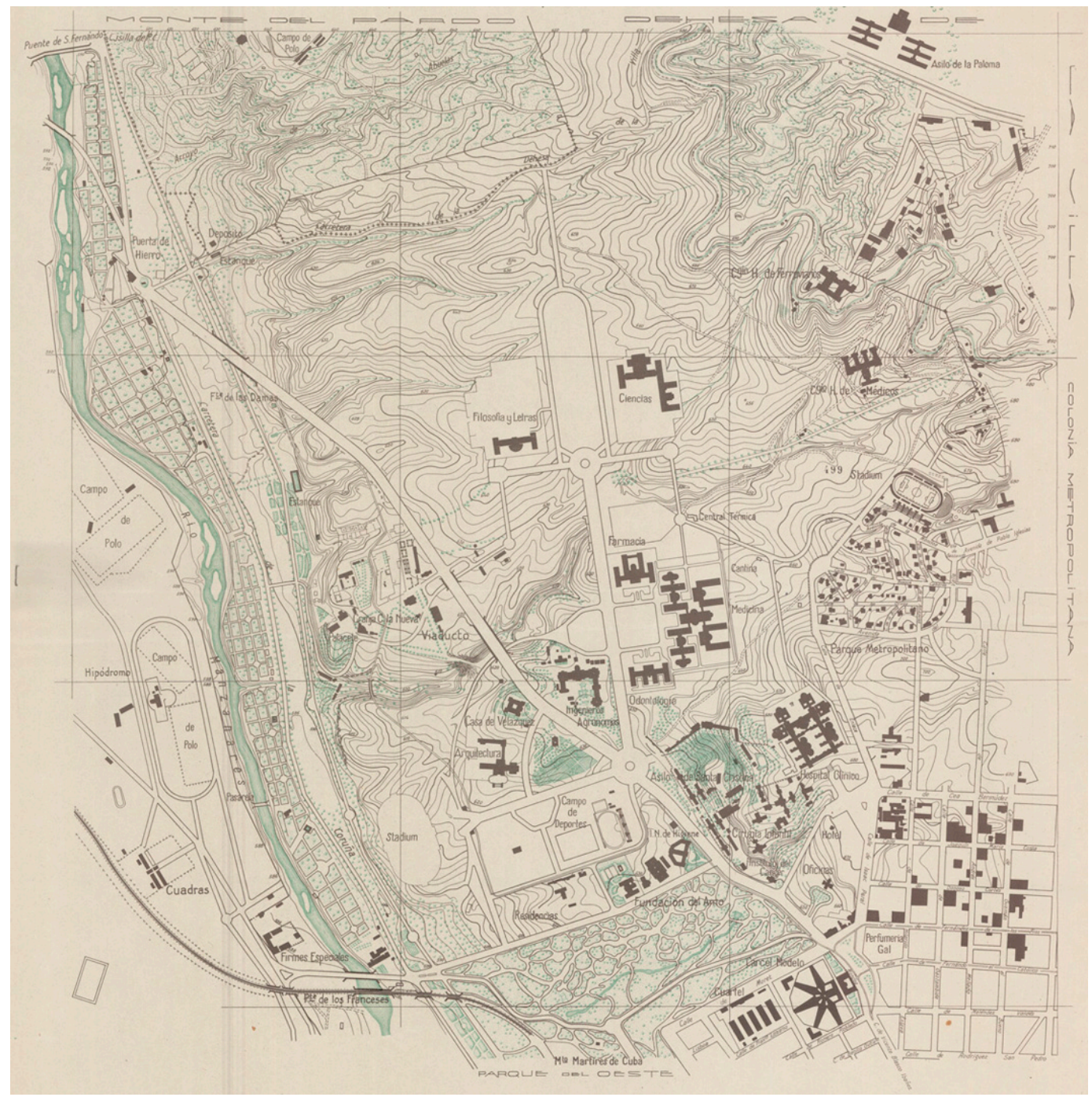

Fig. 36. Plano Cartográfico 1939 realizado por los militares, que representa el estado de la Ciudad Universitario Construida en 1936, estado previo al conflicto armado. Centro Geográfico del Ejercito. Archivo Cartográfico y de estudios Geográficos 


\section{p1- Ejes y Estructuras_ [Infraestructura /Vaciados /Cornisas]}

Ejes_Los ejes, son en arquitectura, las líneas definidas por puntos en el espacio, en torno a la cual se disponen formas y espacios. Normalmente se refieren a ejes de simetría, ortogonales o espaciales, respecto a la cual una figura se analiza o se describe su posición y relación en el espacio o plano.53

Estructura_ La estructura es el conjunto de relaciones que mantienen entre sí, la disposición y orden de las partes dentro de un todo. También puede entenderse como un sistema de conceptos coherentes enlazados, el modo de estar organizadas y ordenadas. ${ }^{54}$

La idea de implantación era, como se ha explicado anteriormente, abarcar lo máximo de terreno y de superficie disponible, junto con la reserva de zonas para futuras ampliaciones. Las agrupaciones de los edificios en zonas independientes, enlazados entre sí por los viales, configuraron el sistema de ejes del conjunto, que se disponían teniendo en cuenta los lugares más adecuados para cada uno en el emplazamiento. Los espacios generados que resultaban entre ellos, entre estos grupos, eran igual o incluso más importante que los generados en su interior. 55

El proyecto no surgiría como un todo completo, sino como un todo completo y unitario; en sentido estricto, bajo una concatenación de espacios con la posibilidad de ampliación en el sentido longitudinal del eje y de manera simétrica respecto a él. El esquema adoptado fue en base de un esquema axial configurado por un gran eje Norte-Sur, a modo de columna vertebral en cuya cabeza estaba al norte y la unión con la ciudad al sur. La ocupación del área se realizó en función de la menor modificación de la pendiente y la topografía para que la estructura de comunicación entre la partes y las visiones fueran lo más clara y continua posible en todo el recinto.

Un campus con sub-campus, escogidos sus emplazamiento con unos ejes organizadores a modo de arteria principal y varias arterias secundarias cardinales

\footnotetext{
53 Según la RAE:( (Del lat. axis). 1. m. Barra, varilla o pieza similar que atraviesa un cuerpo giratorio y le sirve de sostén en el movimiento. 8. m. Línea que divide por la mitad el ancho de una calle o camino, u otra cosa semejante. 9. m. Geom. Recta fija alrededor de la cual se considera que gira un punto para engendrar una línea, una línea para engendrar una superficie o una superficie para engendrar un sólido.

54Según la RAE:( (Del lat. structūra).1.f.Distribución y orden de las partes importantes de un edificio. 2.f. Distribución de las partes del cuerpo o de otra cosa.

55 No hay que confundir estos espacios con los jardines perimetrales y geométricos que rodeaban a los edificios y en relaciono con su perímetro arquitectónico. Estos espacio se mejoraron posteriormente con la plantación de árboles a modo de bosque, con especie propias y autóctonas del paisaje.
} 
creando el orden y base subyacente, basándose en los viales, en las plaza, y en los edificios que adoptaban una situación ya pre-ordenada.

La avenida, que se fracturaba e inclinaba para conectar con la ciudad, creaba una distorsión que diferencia claramente: zona central jerárquica (Paraninfo, Avenida de la Universidad y Campus de Medicina), con un segundo eje oblicuo que llegaba hasta Moncloa (camino hasta la ciudad), y desde la rótula de ambos, un tercer eje hasta el río Manzanares donde se ubicaban el Campus de Bellas Artes y varios sectores más heterogéneos y de apoyo o servicio.

La Avenida de Alfonso XIII era dentro de la estructura que organiza todo el campus, un eje continuo de visuales y perspectivas mas cortas o cercanas . La Av. de la Universidad era el eje principal a modo de un esquema "elástico" y "adaptable", permitiendo una elasticidad y variedad controlada, que más tarde se desvirtuó y malentendiós6. Funcionaba a la vez como eje visual, columna de la ordenación de los grupos o sub-campus y elemento de relación entra las dos zonas más alejadas del recinto (Paraninfo Norte y Paraninfo Sur). Era el eje principal que empezaba en la rotonda de triple trayectoria. Un especie de tridente (hacia los sub-campus norte, hacia la ciudad, y hacia los sub-campus de la zona del rio). Cada una de estas trayectorias responde a una trayectoria de la columna vertebral, las tres zonas más amplias determinantes en la configuración espacial (Suelo, Ciudad y Paisaje).

- Eje Av. de la Universidad_Suelo.

- Eje Av. de Alfonso XIII (Av. de la República)_Ciudad.

- Eje Av. Seneca_Paisaje

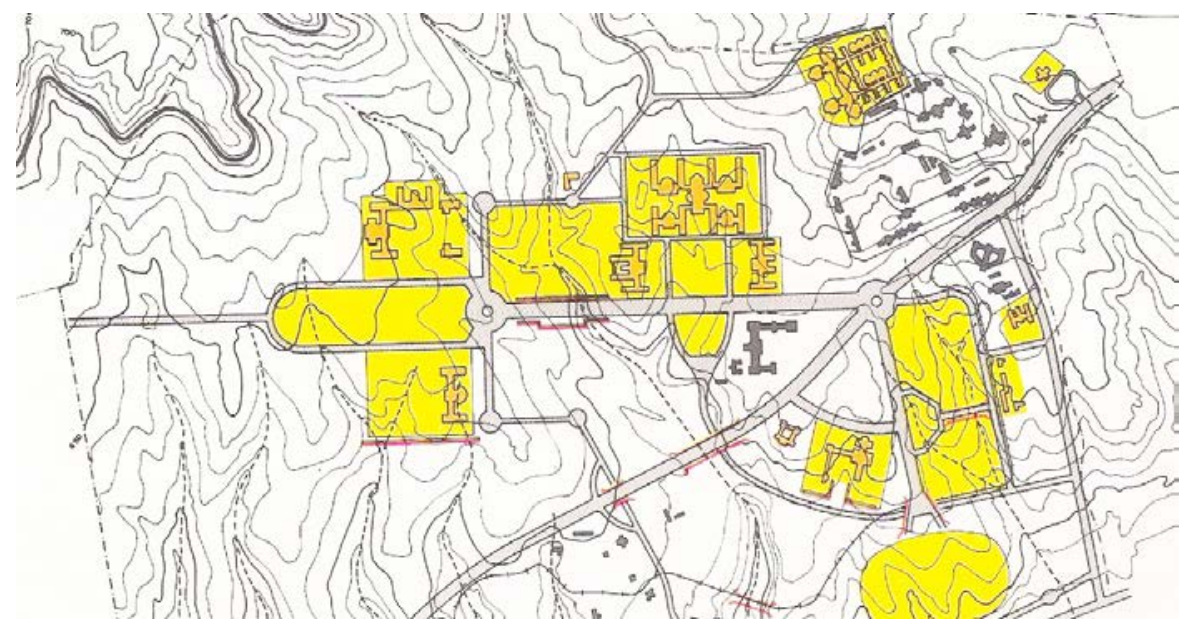

Fig.37. Plano de Infraestructuras y Plataformas. Tesis Pilar Chías

${ }^{56}$ La flexibilidad controlada de la estructura urbanística permitía la amplitud o la relación de los grupos en sentido de la Av. de la Universidad. Pero en época de desarrollo posterior estos espacios se colmataron y densificaron por la construcción descontrolada. 


\section{Infraestructura /Vaciados /Cornisas}

Como se aprecia comparando los planos de topografía con los de movimientos de tierra, el proyecto ordenador apenas tuvo en cuenta, a priori, la topografía y la vegetación del lugar, lo que provocó importantes daños paisajísticos ${ }^{57}$. Vaciados y desmontes que se realizaron para crear las plataformas donde se apoyarían las construcciones, destrozando parte del recinto del lugar, grandes modificaciones y variaciones de la topografía en la parte más al norte y cercana a la cornisa de la ciudad.

Una modificación como error y destrozo, para muchos, junto con la idea de trazar la salida entrada de la capital por la Av. de Alfonso XIII, como un gran acceso por la Ciudad Universitaria, lo que la convertiría más tarde en una arteria de tráfico insalvable y continua, que no haría más que dividir y seccionar más el lugar58.

El resultado final de esta fase de movimientos de tierra produjo la disponibilidad de una banda de terreno en sentido Norte-Sur, a una cota oscilante entre los 635 y los $645 \mathrm{~m}$ de altura, así como la de otras en las zonas de deporte y residencias que se configuraron en terrazas, entre los 600,los 610 y los $620 \mathrm{~m}$ de altura. La variación con respecto a las topografía primitiva era sustancial y los encuentros entra ambas hubieron de forzarse en mucho casos acudiendo a las tecnologías disponibles. De esta forma empezaron a aparecer viaductos, puentes para el viario, muros de contención... se llegaron a emplear 20.000 m3 de hormigón ${ }^{59}$

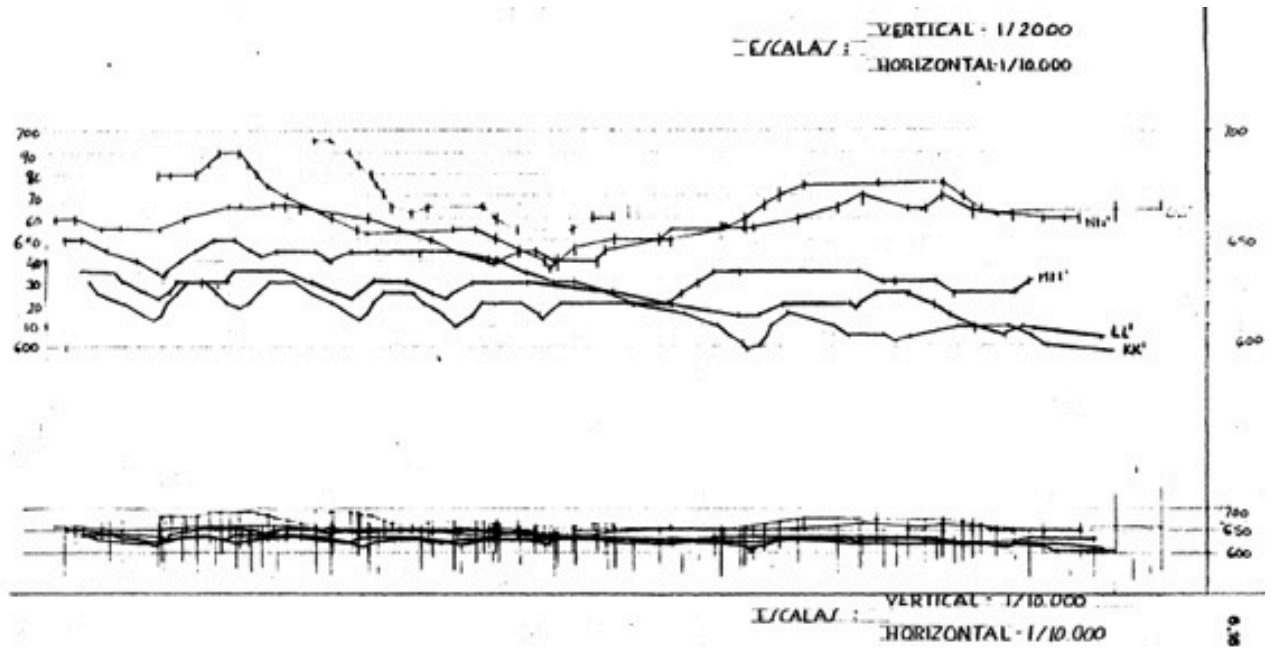

Fig.38. Secciones Trasversales Verticales y Horizontales. 1928 Tesis Pilar Chías

\footnotetext{
${ }^{57}$ Se calcularon en más de un millón de metros cúbicos removidos.

58 Permitir el paso de coches y carruajes a la Av. de la Universidad, rodando por la "espina", como se ha detallado en el Proyecto de la Republica, también agravó la separación de las zonas en disciplinas, la creación de barreras física y psicológicas que obstaculizaban las relación entre los alumnos de diferentes enseñanzas.

${ }^{59}$ Chías Navarro, Pilar. La Ciudad Universitaria de Madrid. Editorial Complutense. p. 117. Fuente de Datos: Folleto publicado editado por la junta en 1930.
} 
Torroja fue el ingeniero que planteó y organizó las primeras obras de infraestructuras ( 3 viaductos, 3 pantallas de contención y 7 plataformas) con los movimientos de tierras, plataformas y vaciados. La creación de muros pantalla y viaductos para salvar los grandes desniveles de terreno y vaguadas, en función del viario diseñado, era el elemento configurador de los ejes y la estructura del solar. La técnicas se puso a disposición del proyecto urbano y arquitectónico , pero en contra del paisaje natural existente. Las obras de infraestructura comenzaron hacia 1929, intentando:

- Crear la mejor línea de rasante homogénea en el campus.

- Facilitar la comunicación entre edificios en un mismo nivel.

- Conseguir un máximo de diez metros de diferencia de cota entren los campus de Ciencia y Medicina, lo que se consideraría prácticamente plano.

Una de los pasos más importantes era continuar la línea del tranvía desde Moncloa hasta Puerta de Hierro; con esa idea de continuidad propia que tenia la finca. La línea pasaría por la Vaguada de Cantarrana que provenía a su vez de la línea desde la estación del estadio (también obra de Torroja) ${ }^{60}$. Este paso ocasionó la construcción de un viaducto para salvar el gran desnivel, el llamado Viaducto del Aire. Al igual que este, se hicieron dos mas el de los Quince Ojos y el de los Deportes, construyéndose prácticamente a la vez que las primeras edificaciones. Todos ellos, junto a las pantallas de contención, con el Viaducto de las Damas y el muro de contención bajo la Avenida de la Complutense (actual facultad de Periodismo) son las grandes obras de infraestructura que se realizaron para salvar las pendientes, vaguada y desniveles de terreno

\section{_Viaducto del Aire (enterrado)}

...el viaducto llamado del Aire, ubicado en uno de los valles más hermosos de la Ciudad, valle muy encajado y sobre el cual la rasante del tranvía pasa alta,..61

Se realizó en 1930 con la idea de no perturbar la belleza del paisaje, o hacerlo de manera mínima, un solución ligera, formada por dos arcos gemelos de 36 metros de luz y 18 de altura, muy esbeltos, y sobre los que apoya también un tablero. La idea de la esbeltez y menor cantidad de material, mejoraban tanto la visualización en el paisaje como las condiciones económicas.

\footnotetext{
60 Posteriormente la desaparición de los tranvías en la universitaria, que dejaron de circular, ocurriría en 1967.

61 Torroja Miret, Eduardo: "Los viaductos de la Ciudad Universitaria [Madrid]", Arquitectura no 163 164, noviembre-diciembre 1934. pp. 329-336 
_Viaducto de los Quince Ojos (Dañado y degradado)

El viaducto de Cantarranas o de los Quince 0 jos $^{62}$ sería el de mayor tamaño63. salvando la mayor anchura y altura de la vaguada del arroyo de Cantarranas, con $115 \mathrm{~m}$. de luz y $35 \mathrm{~m}$. de anchura. Se proyectaron 15 arcos de 7,7m.de luz entre ejes en sentido longitudinal y otros 3 en sentido trasversal, en hormigón armado visto Las pilas centrales llegaron a $1,70 \mathrm{~m}$ de anchura y las laterales de $6,80 \mathrm{~m}$ para alcanzar la anchura total. los cuatro medio arcos trabajando como 4 ménsulas capaces de soportar el tablero plano superior del viaducto. ${ }^{64}$.

El límite de la cornisa de la ciudad estaría en el lado opuesto, entre ambos, y con una diferencia de cota entre $660 \mathrm{~m}$ y $695 \mathrm{~m}$, se produce un brutal gradiente de variación de terrenos y vistas, frente al cual la arquitectura de los edificios futuros del proyecto ocasionó una respuesta formal (previamente con la necesidad de aterrazar y unificar las cota de replanteo). La decisión de colocación de todas las construcciones en terrazas, bajo las cornisas en una banda lateral más cercana a la ciudad, originó un espacio que actuaría simultáneamente como un zócalo semienterrado de observación privilegiada y a lo largo de una espina dorsal de la actuación que actúa como barrera entre la ciudad y la universidad. La elevada diferencia de cota entre el río y la ciudad, dejaban a las futuras edificaciones como observadoras desde el límite de la ciudad. Se podría conceder quizá junto, pero lejos del valor paisajístico preexistente, el que la propuesta de cornisa noroeste de la ciudad se convirtiera en una visión de los edificios a modo de vigías o torres elevadas mirando a la sierra, proponiendo un nuevo diálogo o dualidad dentro del recinto de la universidad

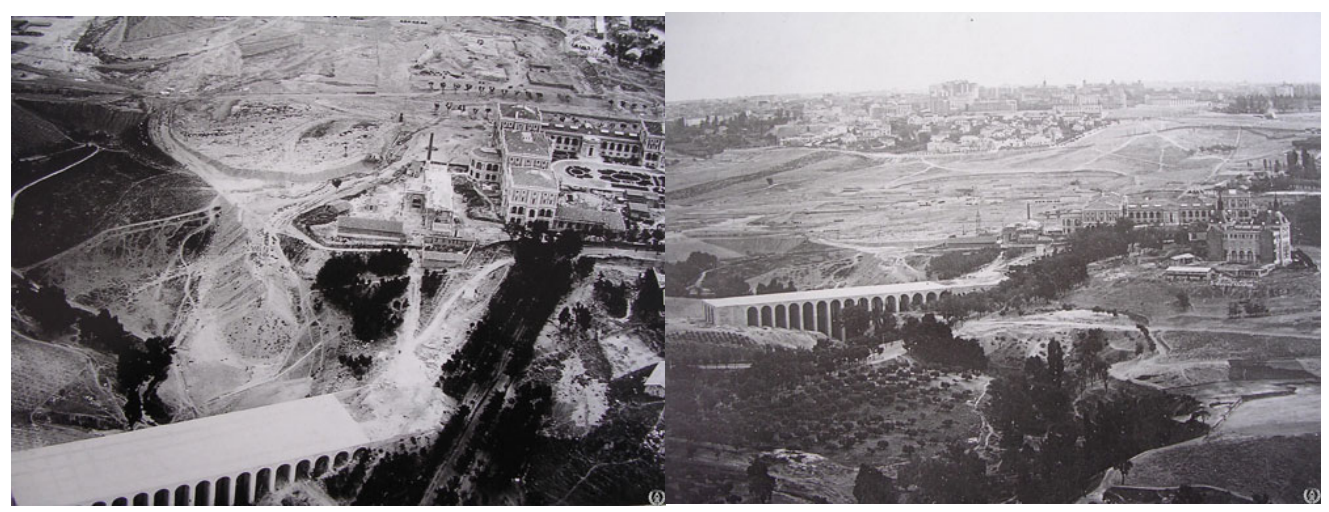

Fig.39 y 40. Imágenes del Viaducto de los Quince Ojos, de un vuelo s/f. aproximadamente de 1930, en las que se aprecian los edificios en construcción. Fondos bibliográficos de la ETSAM

${ }^{62}$ Llamado así por su número de arcadas visibles desde el exterior.

63 Pasos sobre la actual carretera de La Coruña y la antigua Avenida de Alfonso XIII.

${ }^{64}$ Ha sido en la segunda mitad del siglo XX, cuando la degradación y olvido ha sido mayor en esta construcción. Rellenos, ocupaciones y modificaciones que ha degradado el diseño original con cierres de ladrillo, enfoscado y carpinterías sin orden ni jerarquía. En la actualidad solo quedan libres dos de sus quince ojos, los cuales se emplean para el paso inferior de vehículos, otros tres están ocupados como almacén. El diseño y las arcadas originales son irreconocibles. 


\section{p2- Llenos y Vacíos_ [Escala /Contenedor/ /Plaza]}

Los llenos_Se refiere dentro del proyecto arquitectónico para lo material y lo concreto, un espacio que contiene todo cuanto su capacidad permite o que está total o parcialmente cubierto por materia. La volumetría y el espacio masivo que se conforma en el lugar.

El vacío en el lugar_ es la ausencia total de material en los elementos de un determinado espacio. El concepto de vacío arquitectónico sería un equivalente al de espacio arquitectónico, relacionando el vacío con la luz, el aire y el sonido, como Bruno Zevi, historiador y crítico de la arquitectura, los define:

...la comprensión del vació arquitectónico exige una distinta y más completa pericia. Quien no se afane en adquirir la capacidad para verlo y leerlo podrá formular juicios exactos y hasta luminosos sobre la arquitectura, puesto que el arquitecto se expresa no solo manejando vacíos, se expresa también con el manejo de los volúmenes, de las superficies y con la grafía de las molduras; sin embargo debe renunciar a comprender la arquitectura en la matriz secreta de su integridad. ${ }^{65}$

El condicionante de un terreno natural y frondoso de la finca de La Moncloa no podía desparecer solo imponiendo unos ejes, modificaciones topográficas o desmontes para la ubicación de los edificios. El diálogo entre la geometría que configuraban las edificaciones por grupos, con los vacíos que eran la libertad e irregularidad del componente natural, tenía que unirse y fundirse en el mimo proyecto.

Las edificaciones o facultades de cada campus, debían colocarse abiertas en un entorno de zonas verdes. Todas estos campus relacionadas a su vez por la avenida principal. El proyecto permitía la variación y movilidad de los sub-campus en función del diseño y con idea de posibles ampliaciones ${ }^{66}$.El proyecto se basaba en una serie de concatenación de sub-campus- espacios que se repiten sucesivamente, de modo que la repetición de espacios y la utilización de sucesivos quads era la fórmula espacia utilizada. Es normal que al utilizar la forma de células compactas de elementos rectangulares abiertos a uno de sus lados abrazando la idea de relación intersticial dejaran entrever la posibilidad de permitir posibles ampliaciones.

65 Zevi, Bruno. Arquitectura, Poseidón. 1969, P. 68-69.

${ }^{66}$ Se consideró la posibilidad de un aumento del número de alumnos en un $20 \%$, dejando los espacios libres alrededor de las construcciones para ampliaciones futuras. Sin embargo, según la tesis de Pilar Chías Navarro esto sería contradictorios con el diseño de los edificios cerrados en sí mismo. Quizá las ampliaciones no sería de los edificios sino a base de repeticiones de conjuntos de manera paralela y secuencial. 
El campus madrileño sería el resultado de la adición, sumatoria o articulación de una serie de entidades semiautónomas, que compartirían tanto la fidelidad e una estructuración de honda raíz unitaria o de conjunto como el ejemplo de un leguaje arquitectónica común. ... la suma de varios campus articulados sobre un gran eje central

\section{Escala /Contenedores/ Plazas}

La solución del conjunto respondía al lugar idóneo por localización, pero no así tanto por topografía y orografía. Todo ello, con una clara relación de que el conjunto universitario era similar a una acrópolis o lugar reducto del saber, diferente a la ciudad y con una relación con la misma de la que parece que estaba a sus espaldas como de fondo y protección, con la sierra y el paisaje madrileño de frente como visión.

Unidad y extensión sería la simbiosis o guía para el trazado pero no tanto la escala del conjunto. Debido a la extensión, que era el soporte físico sobre el que actuar, el proyecto respondería como con un planteamiento parecido a las universidades extensivas americanas, pero con una tamaño muy superior a las mayorías estudiadas como modelo

Las características topográficas del terreno obligaban al proyecto a modificarse para poder extenderse, ocupando y colonizando la mayor parte del recinto, pero sin ninguna necesidad formal de extenderse tanto. El conjunto intentando quizá hacer la menor de las variaciones de tierras, desmontes o vaciados (hecho que quizá no se consiguió, pero sí se tuvo en cuenta) perdió parte de esa unidad que tanto ansiaba.

Cada uno de los núcleos está, a su vez, bajo una ordenación propia, en ejes normales y perpendiculares entre sí; dando lugar a las pequeñas plazas o recintos cuadrados o rectangulares que son los que la tradición americana e inglesa, llamaban campus ${ }^{67}$. Este complejo recinto universitario-campus, era por tanto, un espacio con una configuración espacial interna por geometrías dispuestas entre sí a distancias articuladas, espacios de relación y con edificios completos configurando "plazas" como en un gran contenedor. El complejo de esta familia de agrupaciones de edificios y espacios de relación con sentido, es como pueden ser cada uno de los edificios con los espacios anexos de la Acrópolis de Atenas.

\footnotetext{
${ }^{67}$ Estas agrupaciones o núcleos, de temática y disciplina similar, fueron dispuesto así con una visión de posibles ampliaciones y extensiones para futuras actividades o zonas afines entres ellos. Como era la zona dedicada a Botánica, dispuesta entre Farmacia y Ciencias para que sirviera a las dos y en las que se interpuso años más tarde Biológicas y Geológicas, ampliando la relación pero cortándola desde el punto de vista línea.
} 


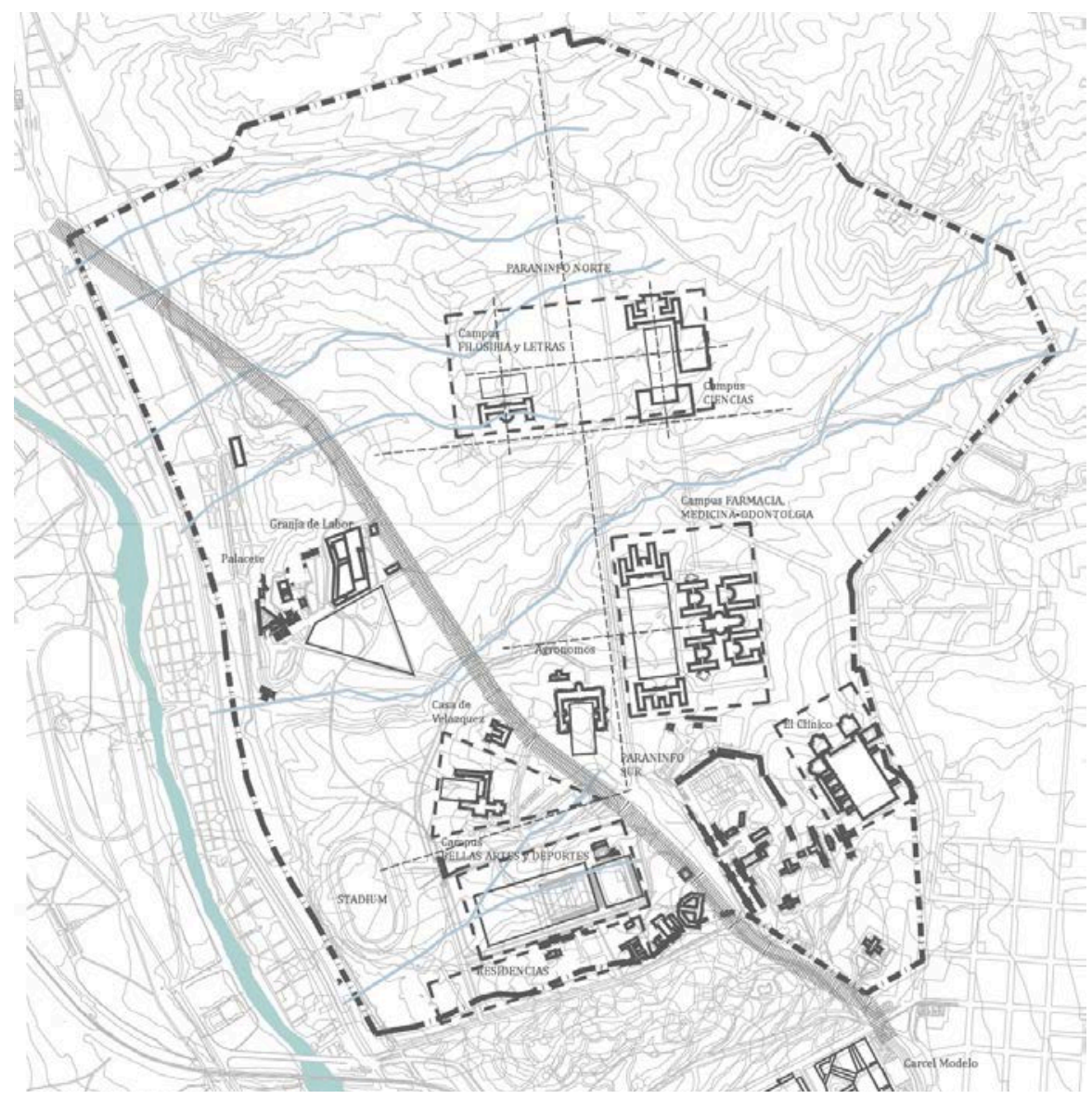

Fig. 41. Llenos y Vacíos. Proceso de Génesis. p.2

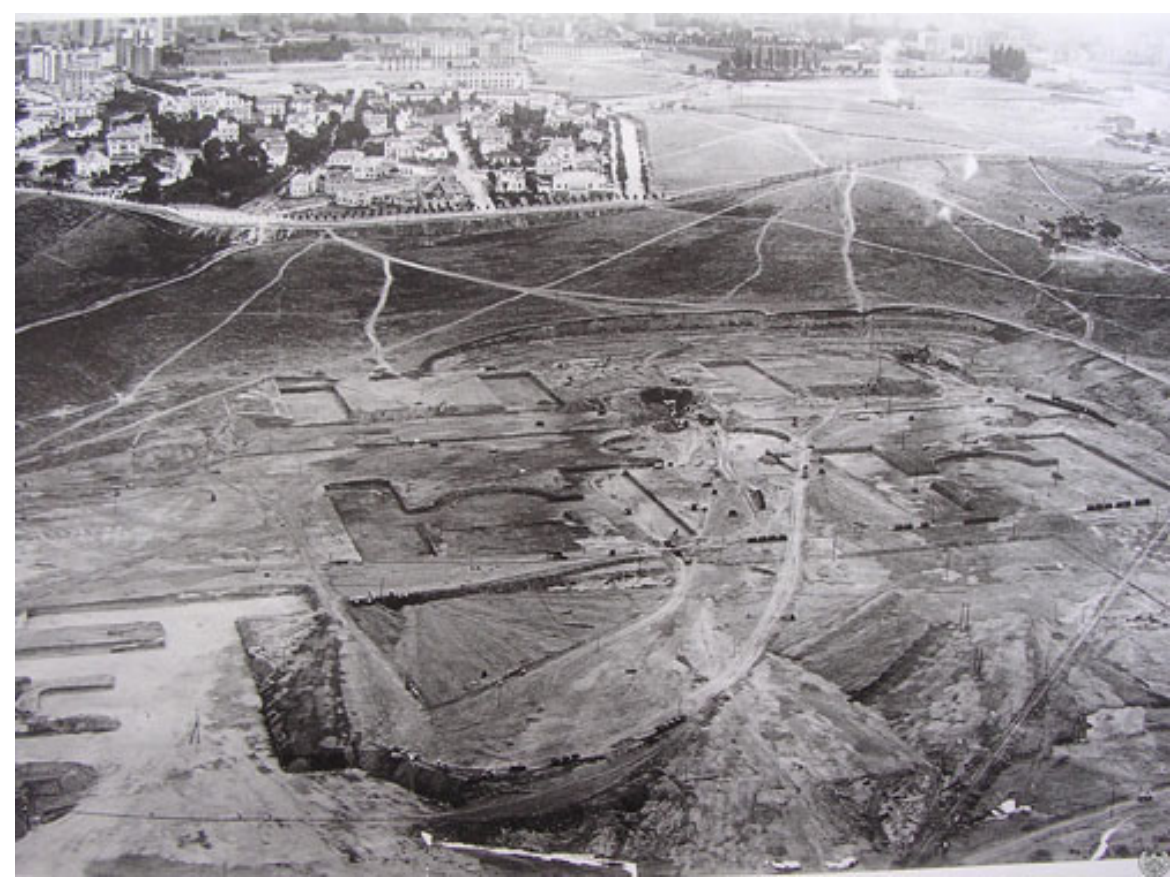

Fig.42. Imágenes del replanteo y vaciado de las obras de Medicina y Farmacia sobre 1930 Fondos bibliográficos de la ETSAM 


\section{Campus/Sub-campus/Quads}

\section{(Collage)}

"Campus"

Era un proyecto de campus múltiple formado un campus único. Pero, que a su vez, cada sub-campus, plaza o "quads" funciona como un collage o campus más pequeño en sí mismo. Independientes pero dependientes entre sí. Un espacio conformado por varios núcleos principales pero que guardan entre sí unos mismos fundamentos espaciales y geométricos que los unen y homogenizan a lo largo de un hilo o línea común que era la Av. de la Universidad. El campus como sostenedor de los espacios abiertos en los que aparcan y se colocan los edificios docentes con la idea de establecerse de manera lógica y ordenada una relación secuencial entre ellos.

\section{"Sub-campus"}

Los sub-campus o grupos pedagógicos en torno a un espacio común, poseen un lenguaje arquitectónico similar y una presencia subyacente. Una serie de células, núcleos o grupos que representaban una forma espacial de "plaza" relacionándose y comunicándose sobre un eje común que se había insertado y organizado como estructura jerarquizándote y conformadores visualmente de todo el ámbito. Esto dio lugar a los grandes grupos en que se dividió los usos:

- Grupo de Ciencias y Letras- Cabeza

- Grupo Médico- Columna

- Grupo de Artes, Residencias y Deportes- Extremidades

"Quadrangle"- "Quads"

Los quadrangles, tradicionalmente en las universidades, fueron la célula espacial de corte geométrico-ortogonal, consistente en un número de edificaciones articuladas perimetrales en torno a un vacío, normalmente ajardinado que actuaba como "alfombra verde" o espacio de estar y relación68. La creación de estos "cuadrados" o plazas, abiertas hacia el eje eran la base compositiva de los grupos en el campus en el proyecto original. Los tres quadrangle en la zona del Paraninfo, uno el de la zona médica, y el último en el diseño original de la zona de Bellas Artes ${ }^{69}$.

\footnotetext{
68 Recordaban y tiene sus orígenes en la traducción de los claustros de los monasterios medievales donde se empezó la enseñanza del saber, y que tuvieron también una aplicación directa tanto en los colegios universitarios hispanoamericanos.

${ }^{69}$ La plaza generando en la Escuela de Agrónomos no se considera sub-campus ni quad en sentido estricto, ya que era una construcción anterior al proyecto y que contaba solamente con un ala y parte principal. Pero a nivel formal y espacial, el conjunto hacia la mimas función.
} 
Los planos del proyecto original de 1928, reafirman la morfología y la utilización del quad como instrumento repetido en la ordenación, configurando un espacio libre geométrico rodeado por volúmenes que servirían para, en el caso de la Ciudad Universitaria una opción formal pero adoptando un estilo arquitectónico afín a los gustos locales.

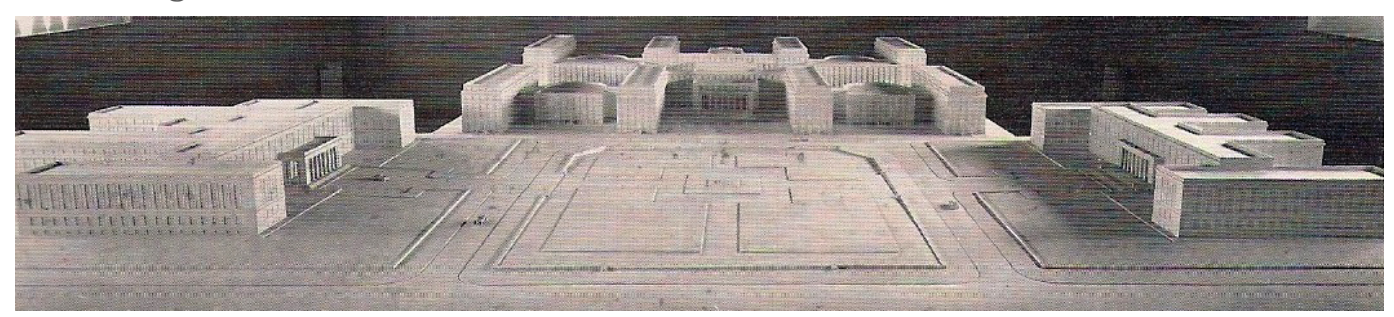

Fig.43 Maqueta modelo del Grupo Sanitario durante la elaboración del proyecto, expuestas en la sala sótano del Pabellón de la Junta o posterior edificio de Gobierno. Plan conjunto 1929.

En los recintos universitarios americanos los edificios que conformaban los quads tenían una "cara" principal con su acceso y un revés, volcando la vida hacia el espacio central. Una relación introvertida, si no se rompen los ángulos, decisión proyectual que sí se hizo en el los grupos o espacios zonales del recinto madrileño. El proyecto de 1928 comprendía los tres grandes núcleos

\section{GRUPO PARANINFO+ LETRAS+ CIENCIAS __ Zona norte (Cabeza)}

- Paraninfo Rectorado

- Facultad de Filosofía y Letras

- Facultad de Ciencias

GRUPO SANITARIO+ HOSPITAL_Z Zona central (Columna vertebral).

- Facultada de Medicina, Odontología y Farmacia

- Hospital el Clínico.

GRUPO DE BELLAS ARTES+ RESIDENCIA _ Zona de río (Pies)

- Arquitectura, Pintura y Grabado.

- Agrónomos y Casa de Velázquez.

- Instituto Nacional de Higiene. Fundación del Amo y Residencias de Estudiantes.

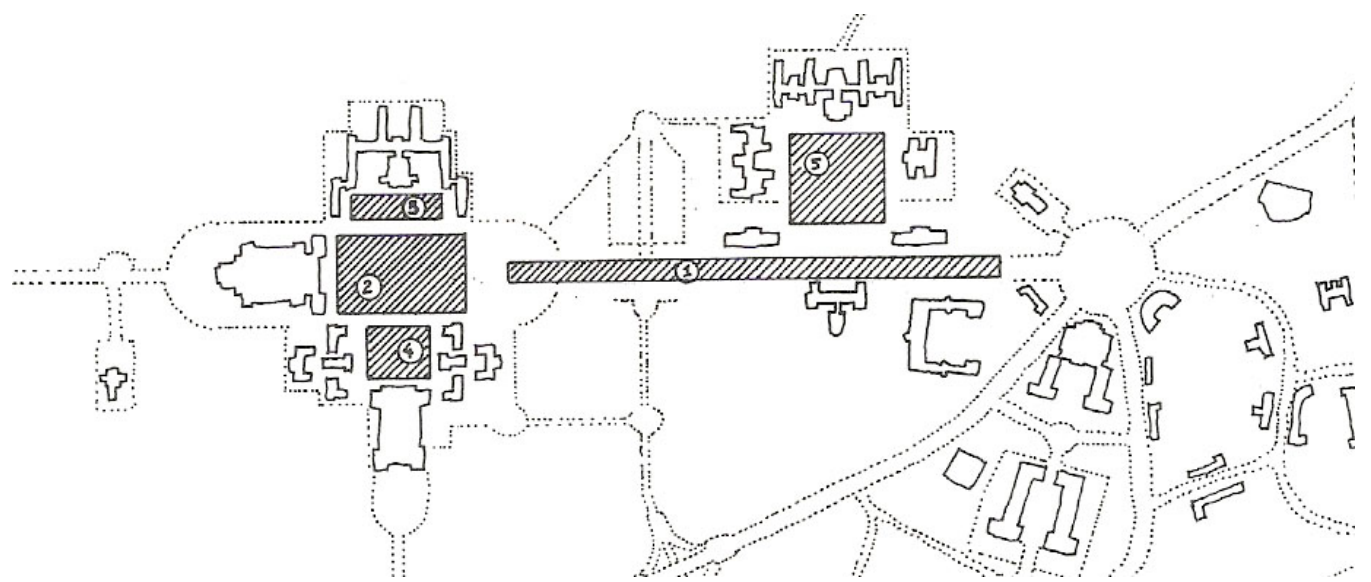

Fig. 44. Esquema grafico de la disposición de quads según el plan conjunto de 1929. CAMPOS CalvoSotelo, Pablo. El Viaje De La Utopía. Editorial Complutense, 2002. p. 92 


\section{GRUPO PARANINFO+ LETRAS+ CIENCIAS}

La intención de proclamar una pieza espacial mediante su volumen y escala a la vez que por la lejanía y amplitud, se hizo presente visualmente mediante un elemento aislado como hito singular a modo de cabeza de la gran espina dorsal. Hay que recordar y mencionar su importante factor simbólico y espacial, que se vera en mayor detalle en el capitulo (c.4), aunque nunca se llegara a realizar.

El Paraninfo como elemento cabeza y con la mayor intención conceptual dentro del campus, como un elemento de marcado carácter con significado propio,. Hubiera conformado un nuevo quad o subcampus con los campus de Ciencias y Humanidades como lados laterales del cuadro o "quad".70

La Facultad de Filosofía y Letras formaba parte del campus más grande de la zona o grupo de letras junto con el Decanato, la Facultad de Historia y la Facultad de Derecho ${ }^{71}$. Por el marcado espíritu funcional, se realizó un edificio moderno y vanguardista que formaba parte de un quad inicialmente abierto que derivó y se trasformó hacia uno cerrado.72.Era un edificio realizado por Agustín Aguirre en dos alas y un cuerpo central a modo de entrada; tenía como fachada principal la cara norte y la fachada semicircular en la fachada sur. De marcada tendencia longitudinal resaltando las ventanas corridas en banda, las impostas de los huecos de fachada y la disposición de las crujías paralelas a la fachada más larga.

Un pieza volumétrica clara con su fachada posterior visible con un cuerpo semicircular, tenía acceso a los jardines ${ }^{73}$ siendo el tratamiento de las zonas bajas lo más importante a nivel de proyecto y relación espacial con el exterior. El jardín era una prolongación del edificio, la construcción se realizó en estructura de hormigón armado y fachada de ladrillo visto, las impostas, cornisas y detalles en piedra caliza cerámica marcaban todavía más la horizontalidad en su visión lejana ${ }^{74}$.Fué el primer elemento arquitectónico terminado del conjunto. Un edificio que esta situado de espalda que reconvierte su fachada posterior en su mas relevante.

\footnotetext{
70 Nunca se llegó a construir y todavía hoy la Ciudad Universitaria permanece inacabada y descabezada.

71 Del conjunto proyectado solo se realizaría Filosofía y Letras (actual Filología y Filosofía) y más tarde la facultad de Derecho por Agustín Aguirre y su ampliación de Francisco Javier Carbajal. Nunca se realizaría el proyecto de la plaza cerrada al lado norte de El paraninfo.

72 Esta facultad falló el proyecto en 1932, al años siguiente empieza su funcionamiento en una de sus alas y se concluye su totalidad en 1936. Fue la primera inaugurada.

${ }^{73}$ Fue llamativo la utilización tanto en construcción como en temas de acústica de los últimos avances, medios de proyección y mejoras técnicas del momento.

${ }^{74}$ Quedó prácticamente destruido durante la guerra por ser un blanco bien visible desde la lejanía.
} 
¡Renovación del cuerpo y del espíritu! La facultad de Filosofía y Letras despierta a una nueva vida en un nuevo paisaje"75

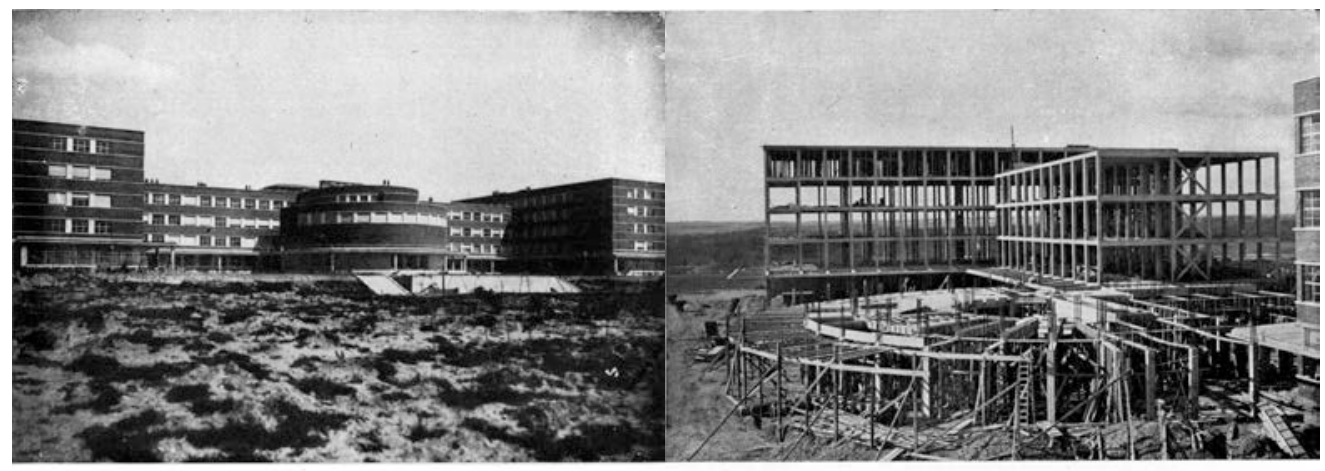

2. Fachada posterior.

12. La estructura de la gran cátedra en 27 noviembre 1932

Fig. 45. Fotografías de la Escuela de Arquitectura durante su proceso de construcción 1934. Libro Huarte y Cía. S.L. Fuente: Archivo histórico digital ETSAM

La Facultad de Ciencias formaba parte del quad o campus del mismo nombre El grupo de Ciencias lo conformaba inicialmente cuatro pabellones o edificios que se clasificaban por cada una de la secciones que compone la facultad de Químicas, Físicas, Naturales y Exactas, conformando un nueva plaza o quadrangle dentro del campus norte; el conjunto de volúmenes era de escala y tamaño muy semejante a su homólogo, estando emplazado simétricamente al otro lado de la zona donde se ubicaría el Paraninfo. Durante la evolución del los distintos tanteos del proyecto, apareció como un campus cerrado como su simétrico, pero solo se llego a contruir dos de sus tres lados. Era de estructura de hormigón y se empleó la fábrica de ladrillo con una marcada tendencia por la imposta longitudinal y la seriación o ritmo de las ventanas ${ }^{76}$.

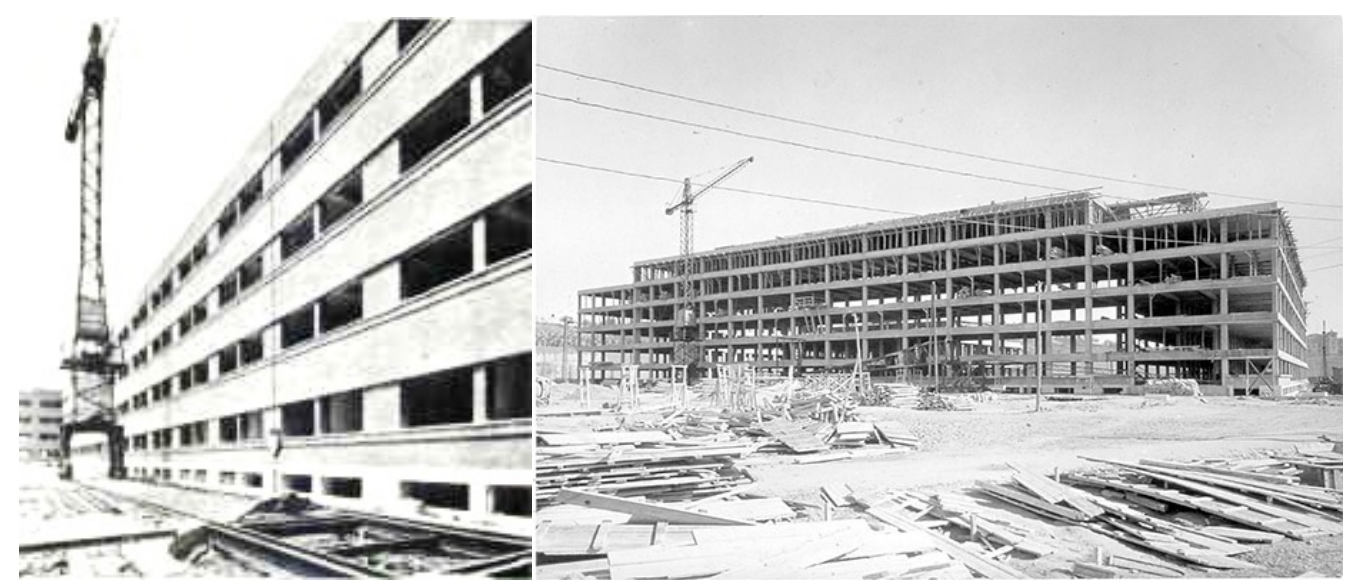

Fig. 46. Fotografías de la facultad de Ciencia tras su reconstruccion.1943. La CUM. Vol. II. COAM

75 Palabra de Agustín Aguirre sobre La Facultad de Filosofía y Letras,

76 El Proyecto original de 1928 y su construcción parcial entre 1933-36 fue realizado por los arquitectos Miguel de los Santos y las estructuras por Eduardo Torroja La reconstrucción y ampliación posterior entre 1941 y 1943, por Miguel de los Santos y Ernesto Ripollés se realizó sin los otros dos cuerpos que cerraban la plaza, por lo que quedó inconcluso. 


\section{GRUPO SANITARIO}

El grupo sanitario componía el sub-campus de mayor tamaño y envergadura. La localización de las tres facultades en medio del eje y su apertura al mismo le hacen visible a ambos lados de la avenida. Los tres edificios de plantas puramente academicistas, simétricas y clasicistas generan un espacio interior a modo de gran plaza-patio de comunicación y relación. Un cuarto "quad" donde las fachadas, a pesar de ser tres diferentes, parecen similares en composición y formando parte de un mismo elemento. Su disposición casi anexa y la poca apertura en sus ángulos las hacen parecer más cerca de lo que están asemejando alas de un edificio en bloque ${ }^{77}$.

La posición, orientación y forma del hospital Clínico, estaba condicionada por su relación con la Facultad de Medicina. El hospital se localiza sobre la ladera o explanación que se ejecutó a espalda de la facultad con la posibilidad de tener una doble entrada y visión de todo el recinto universitario. La relación entre los hospitales con los centros del grupo sanitario, y dentro de éste, su orden y relación entre las piezas que lo conforman, hacen que en el caso de La Ciudad Universitaria funcione diferente con respecto a los modelos americanos en los que se basó.

La simetría del grupo de Medicina y su doble acceso, era un claro ejemplo de su idea de comunicación directa con el hospital, aunque la topografía no lo permitiera y esa relación quedara más en cercanía en plano que en la realidad.

La Facultad de Farmacia es el edificio situado más al norte que cierra el subcampus sanitario78. Su arquitecto Agustín Aguirre lo diseñó pensado quizá que funcionara de manera unificada con los otros dos, para formar un solo conjunto, realizando las fachadas en ladrillo visto y un gran pórtico monumental como acceso (simétrico a Odontología) y similar al de Medicina. Pese a la similitud en apariencia y forma volumétrica a las construcciones anexas de Miguel de los Santos $^{79}$, es ejemplo de la limpieza y claridad, en la limpieza de sus huecos y la proporcionalidad de los ritmos en fachada.

Era un edificio en planta bastante similar al de Odontología, aunque los cuerpos más septentrionales eran más largos y desarrollados, añadiendo un cuerpo central a modo de fachada posterior por el que ser tendría acceso al Jardín Botánico ${ }^{80} \mathrm{y}$

\footnotetext{
77 Podrían parecer le espacio central del MIT, cuando en verdad función como el campus médico de Harvard, cuyos ángulos están abiertos.

${ }^{78}$ Llamada erróneamente la "plaza de Medicina".

${ }^{79}$ Arquitecto que diseño las Facultades de Medicina y Odontología.

80 Proyecto de Jardín Botánico que nunca se realizaría y que quedan numerosos planos y propuestas
} 
que podría haber sido compartido con Ciencias ${ }^{81}$. La doble entrada de la Facultad de Farmacia hacía que su relación con Ciencias por medio del Jardín Botánico y con el exterior pudiera funcionar como un edifico-pasante y de comunicación fácil con el exterior. Hecho que se olvidó y no funcionaría nunca como tal.

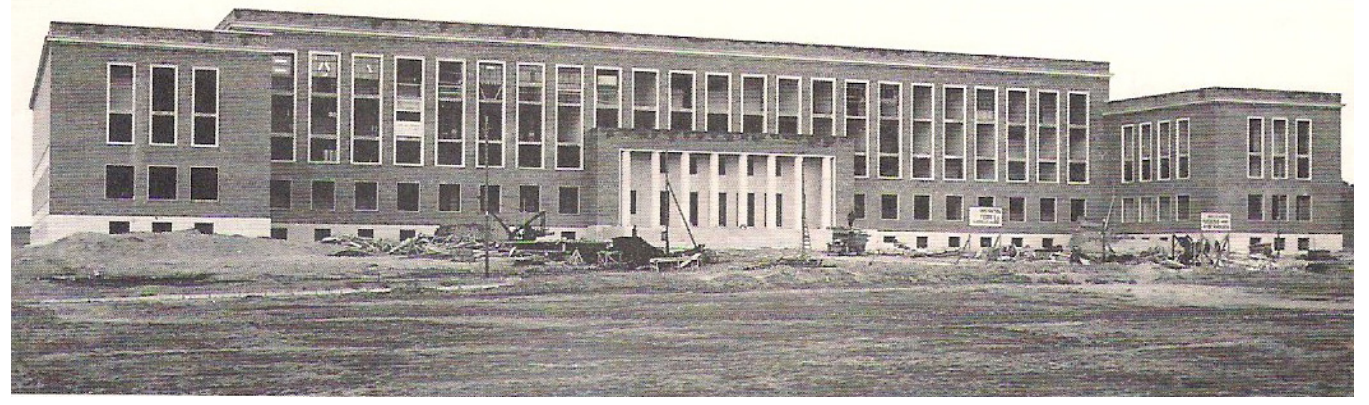

Fig.47. Fotografías de la facultad de Farmacia. 1932. La CUM. Vol II. COAM

La fachada posterior parecía enfrentarse en la lejanía a la Facultad de Filosofía y Letras, y al ala futura de ciencias, que no llegó a construirse. Elementos en el conjunto cuyas fachadas posteriores funcionarían como elementos de relación y favorecían la interacción entre laos campus tan distanciados en le campus.

La Facultad de Medicina, siendo el volumen central y más lejano respecto al eje del complejo de tres cuerpos, fue realizado por Miguel de los Santos, siendo el de mayor influencia americana. Estando localizado en el centro neurálgico y más visible del campus, en el eje principal de llamado Campus de la Medicina, queda flanqueado entre las dos construcciones anexas. De planta compleja, los accesos se realizan siempre al interior del edificio de manera axial, siendo la entrada principal el gran pórtico monumental con columnatas situado en el eje central del conjunto y los accesos secundarios por cada pabellón o cuerpo en el eje de los mismos $^{82}$. La monumentalidad, limpieza y rotundidad de los ocho volúmenes primaticos y su conexión por galerías retranqueadas es lo le hizo ser el más característico y remarcable en todo el campus del recinto.

Tanto desde la parte superior (a la cota del Clínico) como desde la zona de la Avenida a nivel inferior (plataforma de la universidad). Los volúmenes realizados con crujías paralelas a las fachadas de mayor longitud favorecen la modulación de todo el conjunto. La estructura ${ }^{83}$ conformaba sus vanos rítmicamente dispuestos

\footnotetext{
${ }^{81}$ Con la realización de los proyectos de Biológicas y Geológicas en la época desarrollista esto ya se convirtió en casi imposible

82 Esto se realizó de manera contraria a las salidas en el complejo médico de Harvard, donde las entradas se producen por el lateral de los edificios. Quizá por una idea más de plaza de tránsito y comunicación.

83 De hormigón armado a base de pórticos perpendiculares 
en función de la distribución interior que se hizo un sistema métrico estándar84. Las fachadas eran de ladrillo visto, Molduras, jambas, cornisas, zócalo y demás elementos decorativos eran de piedra gris granita, Las ventanas y antepechos (antiguamente negros y ahora blancos) le dotaban de una marcada verticalidad en todas sus fachadas, unidades verticales que le dan un ritmo secuencial y marcado en todo el perímetro ${ }^{85}$.

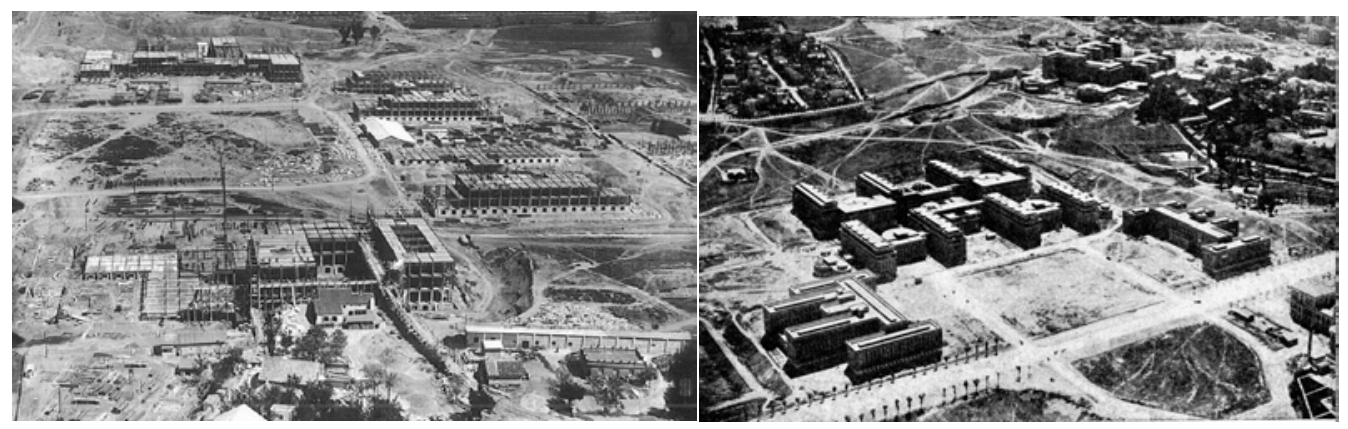

Fig.48 y 49. Fotografías de el Grupo Medico en fase de construcción y terminación. 1932-1936.

La Facultad de Odontología, cierra y termina el lado sur con el campus sanitario. Fue proyectada por Agustín Aguirre86, siendo una edificación que se proyectó con planta en " $H$ " con cuatro pabellones salientes posteriores de igual longitud. Su fachada era acorde con el de medicina y funcionaba casi como un ala lateral, su pórtico y columnata de entrada (simétrico a Farmacia) resulta más llamativo y pesado debido a la escala del conjunto y su menor anchura. Su horizontalidad es más marcada, solo rota por los ejes verticales de las ventanas.

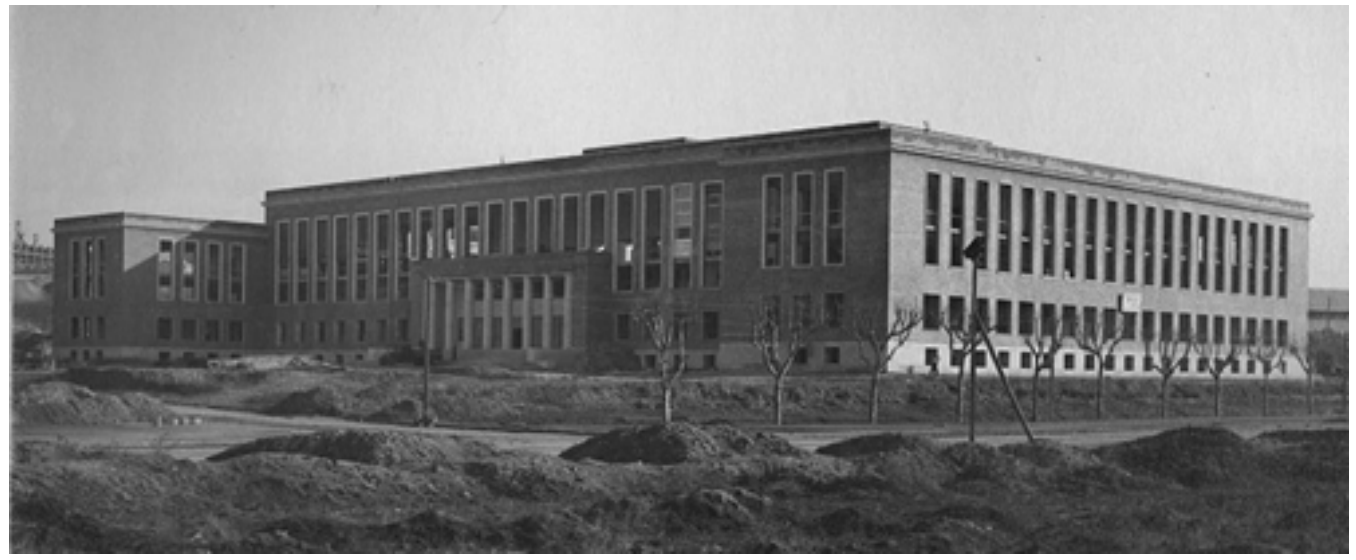

Fig.50. Fotografías de la facultad de Odontología..Fachada principal y lateral, 1933. AGUCM, SG-2402,4q.

${ }^{84}$ La medida de las mesas y material de laboratorio, así como del número de alumnos que podría albergar se basaba en sistemas métricos modulares en función de las luces y las crujías utilizadas para la mejor adecuación y aprovechamiento del espacio.

85 Cuando esto se pintó en blanco en reformas posteriores, el efecto se anuló totalmente. A diferencia de las universidades americanas de referencia, la influencia clásica y de estilo monumental en los pórticos de entrada, la alejaban del estilo más victoriano o gótico que utilizaba aquellas.

${ }^{86}$ Su mayor aportación fue sugerir que los técnicos y arquitectos estudiaran ejemplos extranjeros, 
El Clínico (Hospital Clínico San Carlos) El edificio ${ }^{87}$, de gran visibilidad y porte desde la cota o plataforma base de las universidades se asemeja como un castillo en la lejanía. Su localización más próxima a la ciudad le hacía tener una cierta independencia del resto de los edificios del complejo universitario, tanto por su posición más elevada como por su acceso principal próximo a la urbe. Se construyó el edificio de enormes proporciones con una planta compleja alrededor de un patio central, cuya volumetría externa es muy variada y singular, pero limpia y racional. En su diseño se siguió todos los preceptos importados de la arquitectura sanitaria internacional, rompiendo con el modelo tradicional de hospital formado por pabellones independientes que se había realizado en España hasta ese momento.

La planta proyectada originalmente por Sánchez Arcas era de una marcada geométrica en la que predominaba el uso de exedras ${ }^{88}$, ejes de simetría y formas basilicales $^{89}$ (nave central a modo de corredor y naves laterales con funciones varias). La modulación se extiende en todas su planta y se organiza con una planta rectangular a partir de un elemente modular modificable, en función de las necesidades 3,15x5,50 y 3,15x1,50. El exterior era de volúmenes sobrios y las fachadas de líneas sencillas en ladrillo visto tratadas con sobriedad y despojamiento la línea de las construcciones "racionalistas" iniciales de la Ciudad Universitaria ${ }^{90}$.

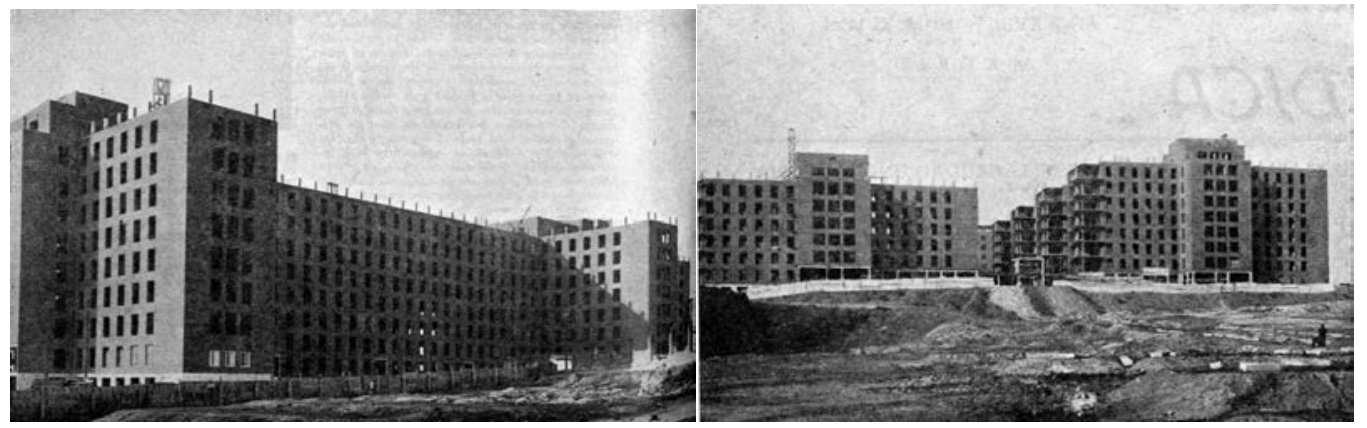

Fig.51 y 52. Fotografías de el Hospital El Clínico, antes de su destrucción.

Fuente: Gaceta Médica Española, 206, nov. 1943, 328-P

${ }^{87}$ El Hospital Clínico se proyectó y se diseñó tomando como ejemplo el Medical Center de Nueva York Uniendo el uso hospitalario y académico en un mismo edificio. Su influencia norteamericana es clara ya que Sánchez Arcas viajo durante tres meses por Estados Unidos y Canadá para conocer los últimos y más modernos avances en este campo.

${ }^{88}$ Construcción de planta circular, con asientos y respaldos fijos en la parte interior de la curva.

89 Planta basilical, basada en la basílica romana y característica del Paleocristiano es una nave central (con o sin naves laterales, separadas de la central por una arquería) con un espacio que dirige la visión hacia la cabecera de la iglesia, donde está el presbiterio con el altar mayor (habitualmente en un ábside). El acceso se sitúa a los pies de la iglesia (habitualmente con atrio y pórtico).

90 Todas las estructuras de hormigón armado fueron calculadas por Eduardo Torroja. El hospital prácticamente terminado durante la Guerra Civil tuvo que ser reconstruido. 


\section{GRUPO DE BELLAS ARTES}

La Escuela de Arquitectura es de los pocos edificios originales que no tenía las llamadas influencia o tendencias americana. Su arquitecto fue Pascual Bravo, ${ }^{91}$ quien realizó la obra en el lugar donde, en el proyecto original de 1929, se localizaba el campus que conformaban Arquitectura con Pintura y Grabado. Un espacio central entre dos alas sobre una plataforma mirador, próxima al museo que se localizaría en la cuña vacía. Un nuevo quad o sub-campus en la zona de trazado vial mas orgánico y curvilíneo.

Su planta está inspirada en la de Gropius en la Bauhaus. ${ }^{92}$. Su bloque central, con una gran escalinata en una fachada simétrica, era el acceso a una construcción sobre una plataforma intermedia entre el rio y la plataforma del campus Sanitario. Su patio sobre la terraza- patio posterío, configuraba un espacio de jardín interior- exterior como prolongación del edificio.

Realizando en un estructura de hormigón armado con un cerramiento de fachada de ladrillo visto trasdosado, la fachada principal del cuerpo de acceso, estaba chapada en la zona central. Esta mezcla de materiales de ladrillo y granito relacionaba a este edificio con el resto de edificaciones de la universitaria a la vez que se relacionaba con los otros edificios con el sentido de monumentalidad de la fachada por las pilastras de orden gigante a la entrada y su marcada y estricta volumetría rectangular en el paisaje.

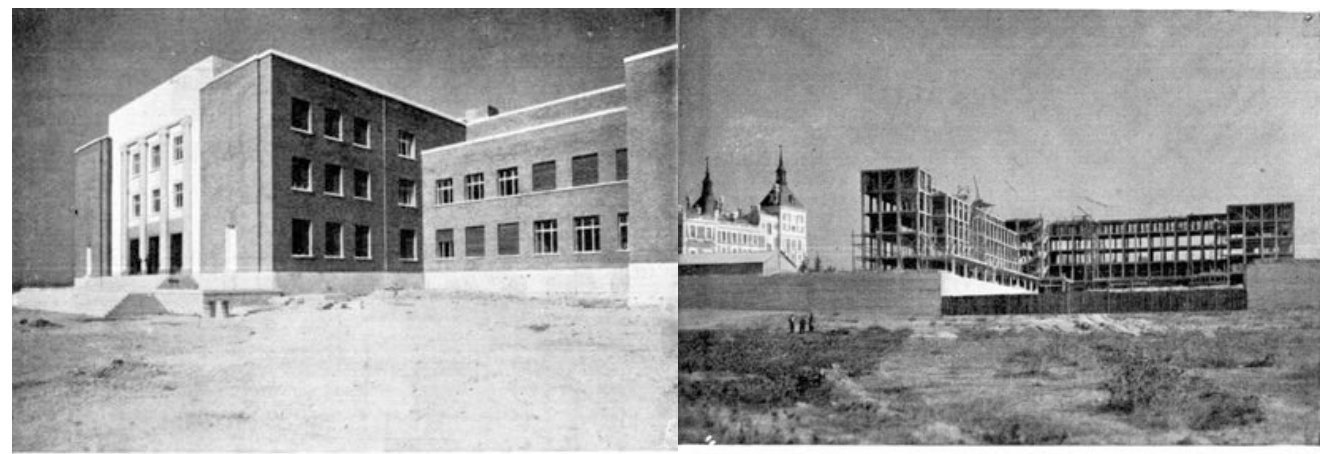

3. Fachada principal. Vista lateral sobre la Biblicteca.

12. Otra vista de la estructura en 28 de enero de 1934

Fig. 53 y 54. Fotografías de la Escuela de Arquitectura durante su proceso de construcción 1934. Libro Huarte y Cía. S.L. Fuente: Archivo histórico digital ETSAM

\footnotetext{
91 Era junto a Modesto Otero de los arquitectos más eclécticos, pero no por ello historicista 92 No así su fachada con su convencional seriación de huecos, muy distinta al lenguaje racionalista de la fachada de la escuela alemana de 1919.
} 
La Casa de Velázquez fue una de las construcciones previas a la construcción de los edificios universitarios en la finca ${ }^{93}$. Su arquitecto fue Chiffot y Lefevre y terminó su construcción en 1936. Era un edificio planteado como un palacio barroco en torno a un patio central cuadrado, con entrada o fachada majestuosa y monumental, con un escalinata en el eje principal y saliente de las torres castellanas en la esquina rematada en chapiteles de pizarra, nada que ver con la edificaciones docentes. El exterior con zona de terraza posterior y un estanque que dejaba ver las mejores vistas de la sierra ${ }^{94}$.

La Escuela Superior de Ingenieros Agrónomos era una escuela también previa al proyecto, en el que quedó integrada. Se construyó en 1869 Junto al edificio, del que solo se construyó la zona central y el ala este. Se añadían pabellones de arquitectura industrial. Los tres bloques en forma de $\mathrm{U}$ se rematan al final con una gran exedra. Sus marcados volúmenes de fachadas de ladrillo, aunque no fue proyectado como tal, la disposición de su segunda ala podría haber configurado un posible "quad" en espacio intermedio entre el campus sanitario y de Bellas Artes.

El Instituto Nacional de Higiene (o de Alfonso XIII) era uno de los edificios sanitarios previos que existían en la finca de la Moncloa, y que se integró en el proyecto. Era una construcción ecléctica al estilo francés y decimonónica ${ }^{95}$

La Fundación del Amo, realizada de manera conjunta entre Rafael Bergamín y Luis Blanco Soler, es una de sus obras primitivas más conocidas, aunque ya ambas inexistentes. Estaban localizadas entre el Parque del Oeste en la zona de residencias de estudiantes, frente a los campos de deporte, y conformaban junto con la residencia del estudiante el campus o zona mas cercana a la urbe.

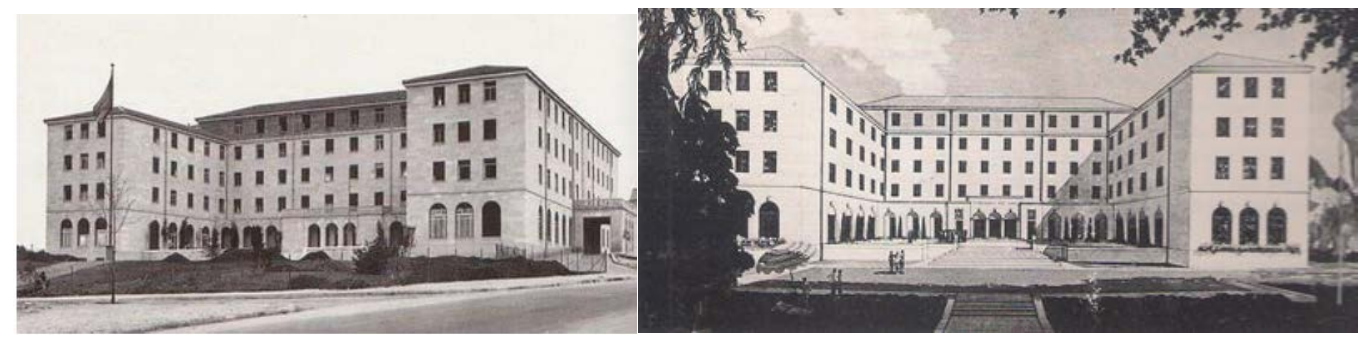

Fig. 55 y 56. Imagen y dibujo Fundación del Amo. www.madrid1936.es

${ }^{93}$ El gobierno francés tras la Primera Guerra Mundial movilizó a intelectuales y a artistas de renombre como estrategia de acercamiento a España. Por iniciativa francesa y gracias a que el rey, que cedió un terreno de 20.000 m2 a Francia, en 1920, se empezó a construir la edificación.

${ }^{94} \mathrm{~A}$ este lugar iba el pintor Velázquez a realizar sus cuadros y al que debe su nombre. Era conocido también porque en la portada de entrada se colocó la fachada el Palacio de Oñate, destruida durante la Guerra Civil que no se pudo recuperar.

${ }^{95}$ Nota aclaratoria. Edificación que podría recordar a al Estación de Príncipe Pio de la Madrid. Algunas fotos desde determinados ángulos, recuerdan en volumen, forma, material e iluminación a la estación de trenes madrileña de la zona Oeste de la capital. No se han encontrado planos ni proyecto de esta edificación. 


\section{p3- Perspectivas y Relaciones _ [Zonificación/ Deporte]}

Las universidades americanas se caracterizaban por amplios campus llenos de relaciones, perspectiva y juego de diferentes visuales entre edificios, algunos de aires historicistas y con amplios espacios ajardinados. El espíritu de la vida al aire libre y la vida joven y espontánea que también surgía en alrededor de las construcciones. Hacían que el espacio entre las edificaciones fuera tan importante como la arquitectura del lugar

Perspectiva_ Como sabemos se define como la capacidad de representar los objetos en la forma y la disposición con que se aparecen a la vista, o como el conjunto de objetos que se visualizan desde el punto de vista del espectador que los contemplan. Es la manera de ver algo desde un punto espacial determinado o la forma de percibir visualmente los objetos en una superficie plana, que da idea de la posición, volumen y situación que ocupan en el espacio con respecto del observador.

Relaciones espaciales_son conceptos que surgen de la interacción entre los espacio entre sí que generan un conjunto y proyecto mayor y los eventos que en el ocurren.

\section{[Zonificación/Naturaleza]}

La topografía del terreno y los ejes en el campus de la Universitaria se pensaron con la idea de provocar continuas visuales y perspectivas en todos los sentidos. Más longitudinales pero con visiones en la zona de la avenida, dirección hacia la "cabeza". Más direccionales y naturales en los viales que bajaban hacia el río por Bellas Artes y los deportes, con visiones más cortas y abarcables. Y las perspectivas panorámicas desde las zonas altas como era la zona del Clínico y las azoteas del grupo médico hacia el paisaje exterior de Madrid. Diferentes perspectivas en un conjunto que aunque heterogéneas demostraban el hacer organizado y homogéneo en su concepción de todos los ámbitos.

... zonificación y viario, en los que se preveía ocupar menos de la dos terceras parte de la finca, manteniendo especialmente intacto el anejo pinar del norte que haría de telón de fondo a la construcciones universitarias. La rectilínea avenida de Alfonso XIII,... divida de forma obligada el recinto universitario y se constituyó erróneamente en la base de la propia urbanización... ${ }^{96}$

Esa sensación de libertad, flujos y relación entre la vida y el estudio se quiso trasladar a la escena universitaria madrileña. Son las edificaciones, su ubicación y

${ }^{96}$ Chías Navarro, Pilar. "La génesis de la Ciudad Universitaria", La Ciudad Universitaria de Madrid. Vol. I p. 187. 
su relación entre ellas generando vacíos, perspectivas y relaciones. Eran base de la trama subyacente en el proyecto:

- Perspectivas y direccionalidades.

- La geometría intrínseca.

- Los contrastes visuales.

- La escala y el volumen.

- La concatenación de espacios.

- Las visiones y comunicaciones diagonales.

- La relación con la ciudad.

- Las relaciones entre las edificaciones.

- La relación entre los grupos zonales.

- El espacio de lleno y vacíos.

- La relación entre zonas, subzonas, grupos o subgrupos.

- La relación ente los cambios en la topografía.

- La relación entre las plataformas de base y cornisas.

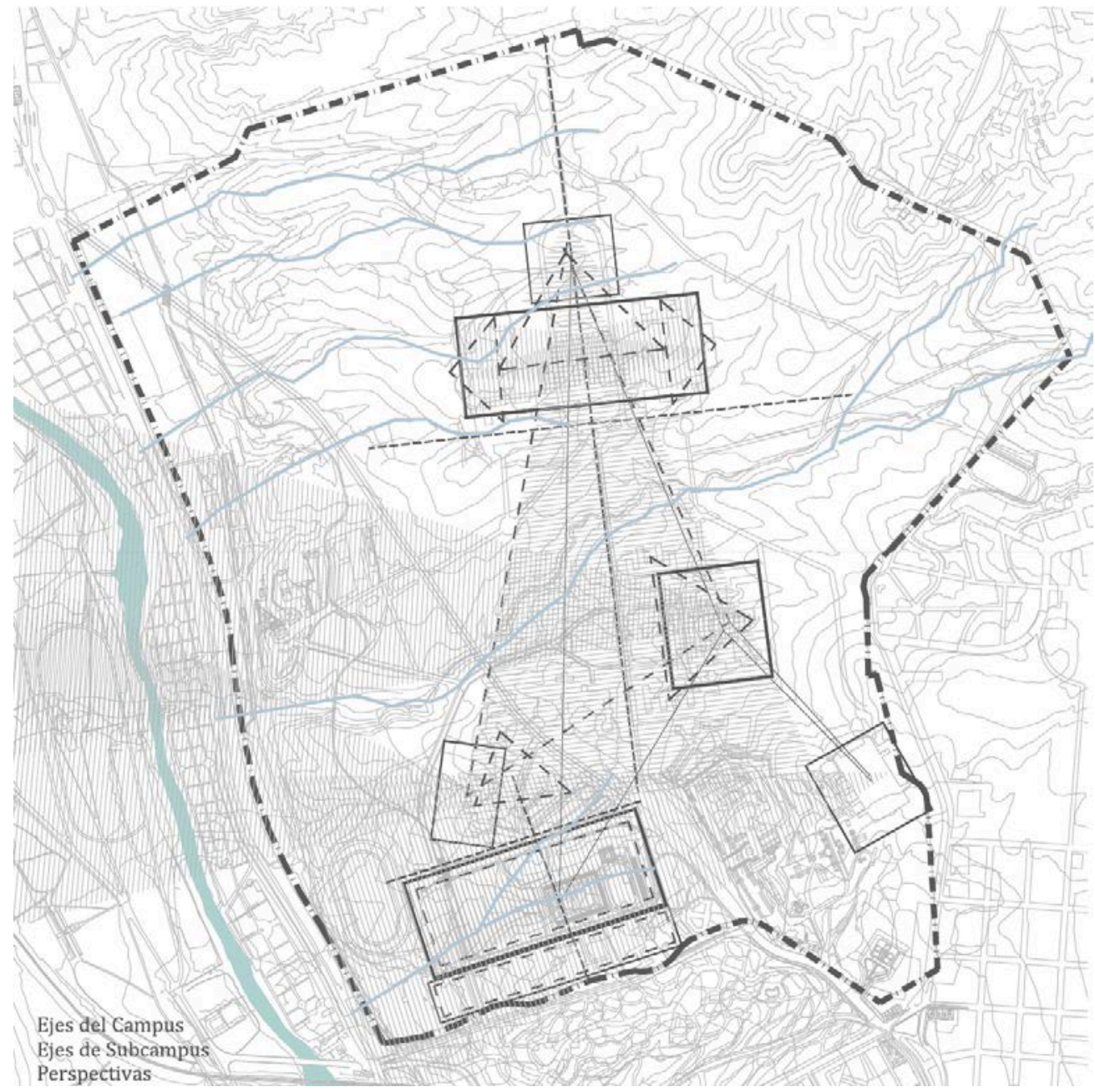

Fig. 57. Perspectivas y Relaciones. Proceso de Génesis p.3 


\section{ESPACIOS VERDES +CAMPO DE DEPORTE}

En el plan inicial de la Universitaria era fundamental la creación de zonas deportivas que se entremezclaran con zonas verdes y edificios. La importancia de estas zonas era una novedad como complemento en la actividad docente y su relación tanto con las facultades como con las residencias. En el proyecto del primer conjunto, solo aparece representado la zona del "Stadium" junto al río Manzanares, la zona más cercana al río, en comunicación con el grupo de Bellas Artes y el Conservatorio. Es en la modificación del primer proyecto 1928-1929 donde aparecen unos usos sin especificar, en una zona cercana a las Residencias de Estudiantes y con un acceso más próximo a la capital, que se dedicarían al uso de actividades al aire libre, con la idea de grandes festejos y celebraciones deportivas.

Durante el trascurso de las obras y con la República, se decidió adaptar el terreno en tres terrazas debido al fuerte desnivel existente. Con una pista de atletismo, una de rugby y otra de futbol ${ }^{97}$, terminando con la piscina y el tenis en el último nivel. En la terraza más baja se proyectó un gran estadio para más de 80.000 personas, situado en el eje con la gran avenida Juan de Herrera, bajo la cual se posicionó le estación del tranvía del Stadium ${ }^{98}$, que comunicaría esta zona con la capital. Un estadio y pantanal para los deportes acuáticos se había proyectado situado a lo largo del Manzanares aprovechando su curso. Una zona aterrazada en cuatro niveles sucesivos que salvaban la diferencia de altura entre la zona del río con las facultades.

Los Campos de Deporte, no formaba parte del proyecto inicial. Junto con Torroja trabajó el arquitecto Luis Lacasa en el diseño de los campos y graderíos del complejo deportivo. Entre las dos grandes campos a diferente cota, se realizó entre 1929 y 1932, un viaducto para comunicar y salvar el desnivel a ambos lados de lo que hoy ocupan el campo de Rugby y de Futbol y que se llamó la Vaguada de la Degollada.

Por tanto se puede entender la construcción de dos maneras: la primera la longitudinal servía como calle para conectar las zonas de los Colegios Mayores con la zona de las universidades y de la calle bajo la que se localizaba la estación "Estadio". La segunda, en sentido trasversal de la vaguada el viaducto (con escasos

${ }^{97}$ Entre estas dos terrazas, el viaducto sería más tarde club deportivo y gimnasio

${ }^{98}$ La estación del estadio así como el viaducto fueron obra de Eduardo Torroja. 
y ligeros pilares) de gran "permeabilidad" servía de conexión visual en tres las dos grandes superficies aterrazada de deporte lo que ampliaba y conectaba los dos espacios y le daba continuidad 99 .

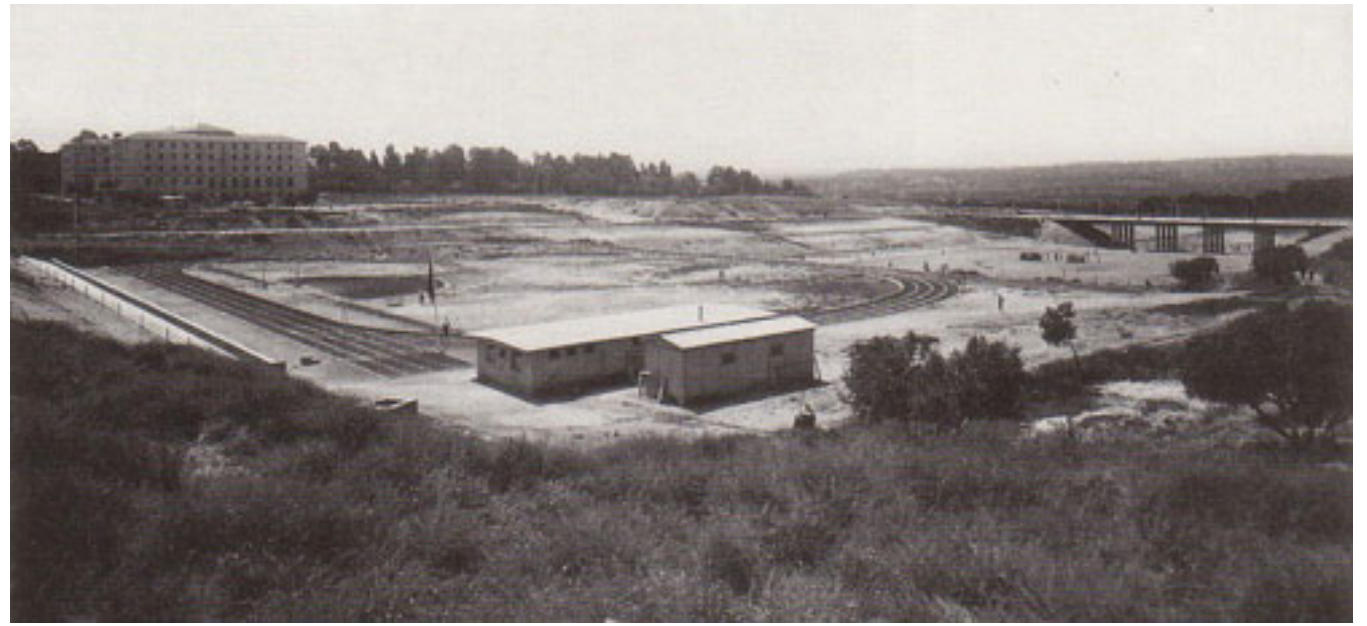

Fig. 58. Campos de deporte 1936.: www.madrid1936.es

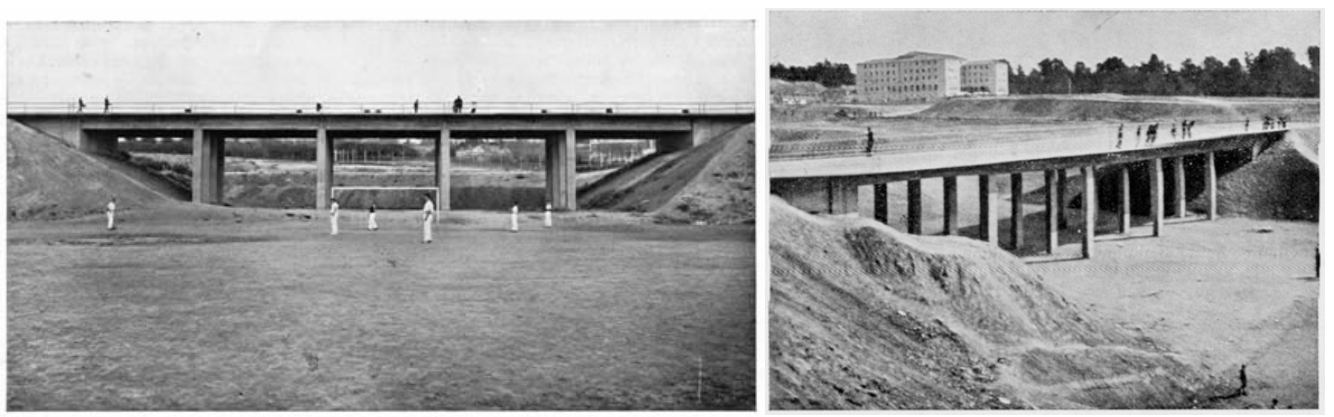

Fig. 59 y 60. Campos de deporte 1932. Fondo del Archivo de la Universidad Complutense.

Aparte de estas obras que por su tamaño pueden considerarse como las principales ha sido necesario construir también un viaducto de menor importancia sobre la vaguada actualmente destinada a campo de deportes, para unir la zona residencial con la zona docente; este viaducto está formado por tramos aislados de hormigón armado, formados por cuatro nervios longitudinales, unidos por el tablero que forma su cabeza de compresión en la forma corriente de viga "pi" múltiple ${ }^{100 .}$

\footnotetext{
${ }^{99}$ Fue en la postguerra cuando el viaducto, sufrió mayores modificaciones del proyecto original. Mientras se diseñó siendo ligero y permitiendo la continuidad visual, la creación de nuevos graderías y el cerramiento por tramos con tres arcos de medio punto, la obra del arquitecto Javier Barroso Ladrón de Guevara99, hizo que se perdiera toda imagen del concepto inicial. Sucesivas reformas en los años ochenta destrozó y borro toda muestra del viaducto inicial.

100 Torroja Miret, Eduardo: "Los viaductos de la Ciudad Universitaria [Madrid]", Arquitectura no 163164, noviembre-diciembre 1934. pp. 329-336
} 


\section{CONCLUSIONES DE FORMA/Génesis.}

- El recinto universitario se ha mantenido separado e independiente en mayor medida que a nivel físico, formal administrativo, ideológico y urbano de la ciudad en todas sus épocas de conformación. ${ }^{101}$

- El proyecto arquitectónico y urbanístico se puede entender como un conjunto de edificaciones y elementos individuales, ordenados en un conjunto. Su relación espacial, compositiva, volumétrica y material la hace ser entendida mas como un todo unitario de "campus" extensivo y subdivido en otros más pequeños a modo de plazas abiertas, "sub-campus" a modo de quads", mas que elementos aislados.

- El concepto de universidad-isla, utópica e idealista, utilizando el campus como modelo, aunque distorsionado en escala, mezclando ideas filantrópicas y humanistas extranjeras y nacionales, supo adecuar un modelo a nivel global, pero no a nivel interno, debido a extensión desmesurada y al nivel o sistema de gestión de la universidad española, a pesar de los buenos integrante del equipo de la Junta.102

- La idea de conjunto y unidad se desarrolló desde el inicio de su concepción, con la idea de cota única; la relación de espacios a nivel horizontal y la intención de visibilidad directa entre las construcciones, originando los primeros drásticos replanteos, vaciados y desmontes iniciales, pero con la idea diluida por la escala desproporcionada en comparación con otros recintos coetáneos o que se habían tomado de muestra.

- El proyecto formal inicial generó unos ejes y estructura de sucesivas axialidades en la zona norte en contraposición a la más natural u orgánica en la zona sur del río. Ambas parte se acoplaron de diferente manera a la de topográfica del lugar. Esta ultima zona seria ejecutada de manera diferente a lo proyectado por lo idílico e irreal del proyecto inicial. ${ }^{103}$

- La decisión de articulación en tridente, desde la vía diagonal principal ocasionó la división en dos zonas opuestas (Cabeza/Paraninfo Norte - Pies/Zonas de Bellas Artes y Residencias) comunicándose por la vía principal de la Universidad (Columna- Eje longitudinal) favoreciendo la coherente coordinación de conjunto unitario, comunicándose por una línea de rasante única, y sin desnivel.

- La idea de campus y sub-campus se distorsionó por las distancias y escala utilizada. Demasiado grande y extensa por las necesidades y las previsiones de uso para el futuro. Hecho que favoreció su ampliación y desarrollo en épocas posteriores, pero no en la línea de coherencia de unidad y conjunto.

- Los espacios centrales al que vuelcan los edificios, por sus dimensiones, no permiten la idea de estancia y permanencia en el campus.

\footnotetext{
101 A pesar de la maniobra de articulación de entrada en la última década de conformación.

102 Junta Técnica Constructora de la Ciudad Universitaria de Madrid

103 Proyecto ideal de 1929 con la realización de la perspectiva en planta caballera del conjunto.
} 

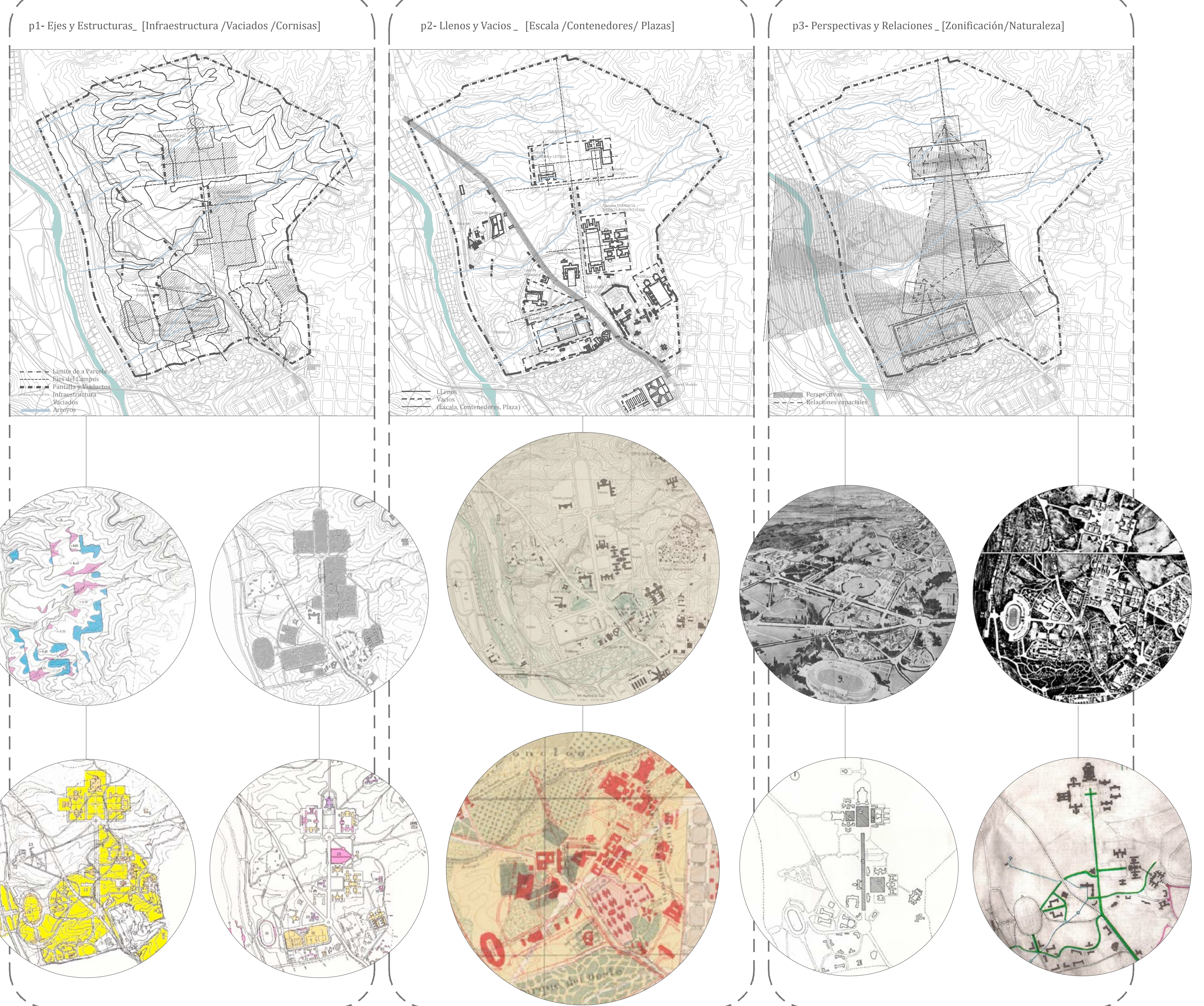

1- Ejes y Estructuras_[Infraestructra Procesos de Génesis 3- Perentivas - [Escala /Contenedores/Plazas] ficación/Naturaleza

Los EJES son en arquitectura, las línea definidas por puntos, en torno a la cual se disponen formas y espacios. Normalmente se refieren a ejes de cual una figura se insertao se describe su posición y relación en el espacio o plano.

La ESTRUCTURA es el conjunto de relaciones que partes dentro de un todo. También puede

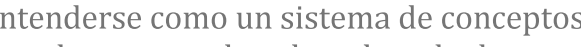
coherentes enlazados, el modo de estar
organizadas y ordenadas.

El VACIO en el lugar es la ausencia total de elementos de un determinado spacio. El concept un equivalente al de espacio arquitectónico, 列cionando el vacio con la luz, el aire y el sonido, Bruno Zevi, historiador y critico de la arquitectura, los define: "...la comprensión del vació arquitectonico exige una distinta y mas
a capacidad para verlo y leerlo podrá formular juicios exactos y hasta luminosos sobre la arquitectura, puesto que el arquitecto se expresa no solo manejando vacíos, se expresa también con el manejo de los volúmenes, de las superficies y de las molduras; sin renunciar a comprender la arquitectura en la
matriz secreta de su integridad"

Los LLENOS se usan para lo material y concreto, espacio que contiene todo cuanto su capacidad permite o que está total o parcialmente cubierto por a que esta tot lo o pas se pueden relacionar edificaciones con respecto al espacio donde se proyecta o construye.

La PERSPECTIVA es la capacidad de representar los objetos en la forma y la disposición con que se aparecen a la vista. Es el conjunto de objetos que se visualizan desde el punto donde esta el espectador que lo contempla. Es la manera de ver algo desde un punto espacial determinado o la forma de percibir visualmente la edificaciones en volume situriona, que da idea de la posición, respecto del observador.

Las RELACIONES espaciales son conceptos que urgen de la interacción entre los espacio entre si que genera el conjunto de edificaciones y los
eventos que entre ellos ocurren La Ciudad Universitaria de Madrid Escala 1:30.000 

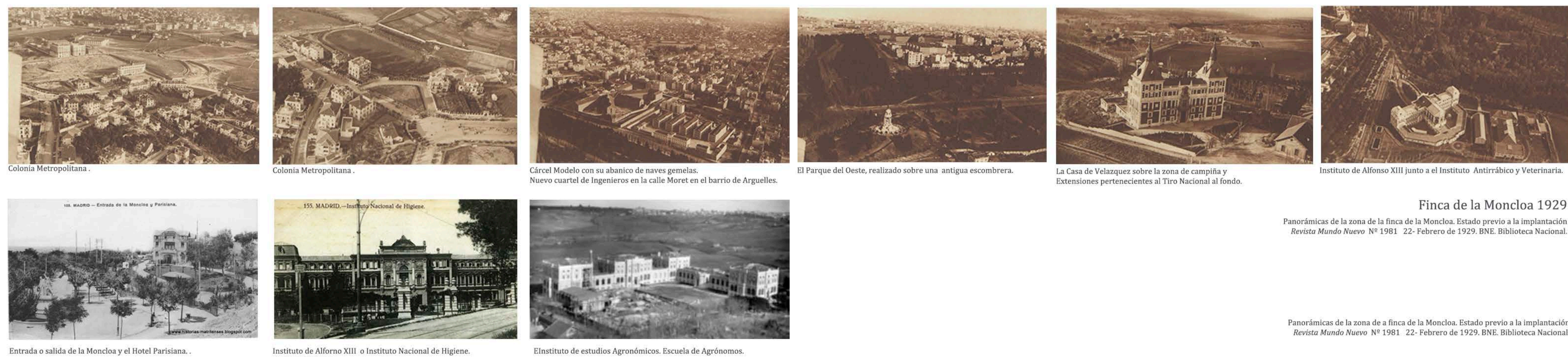

Finca de la Moncloa 1929

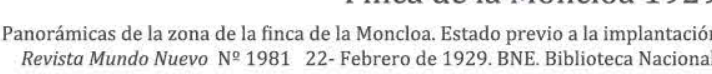
Instituto de Afferno XIII o Instituto Nacional de Higiene
Fachada Principal.
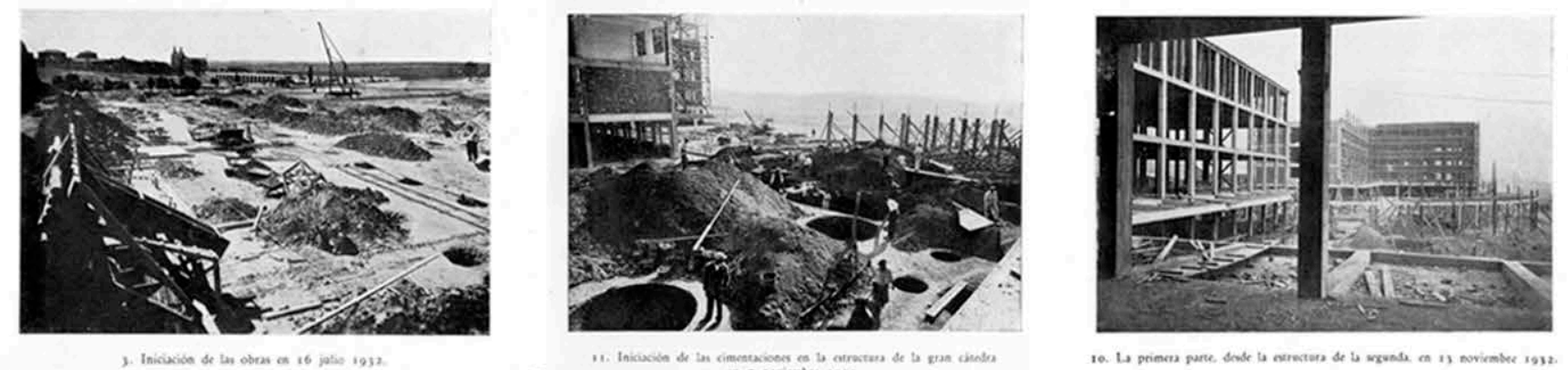

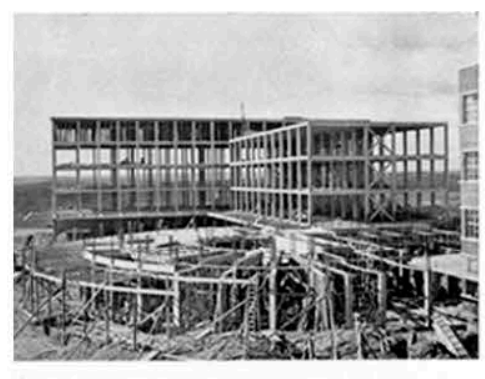

1.
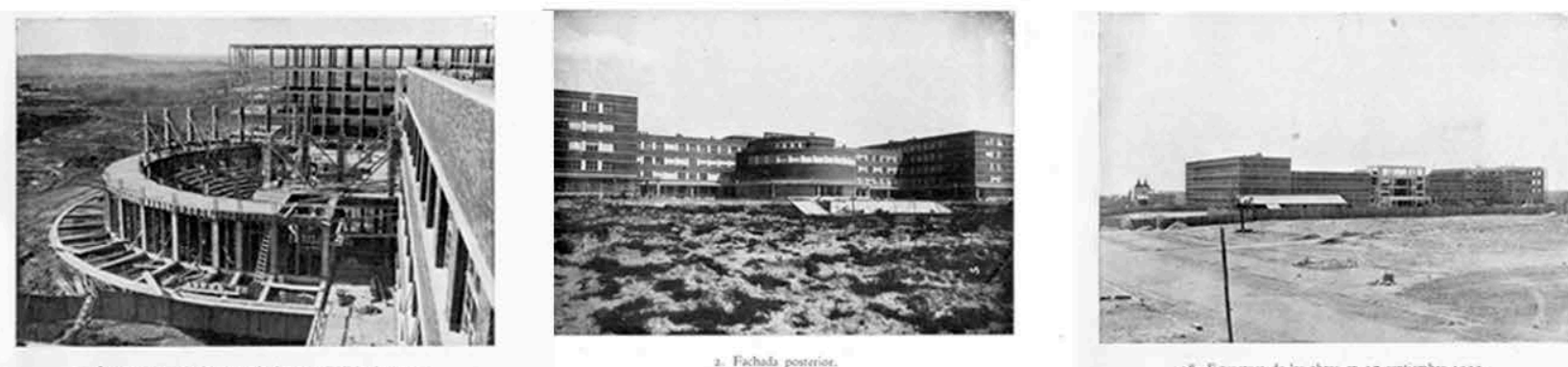

20.0.

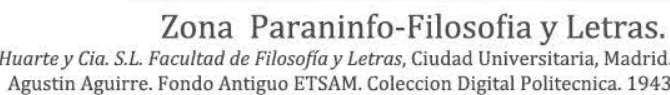
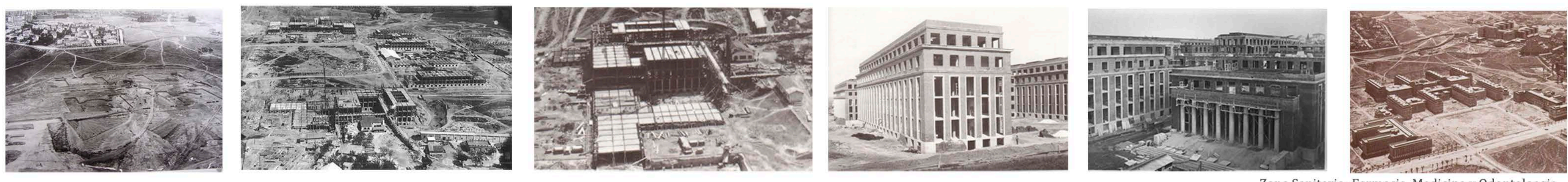

Zona Sanitaria- Farmacia, Medicina y Odontoloagia

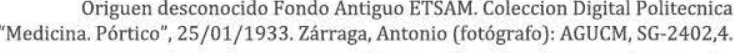
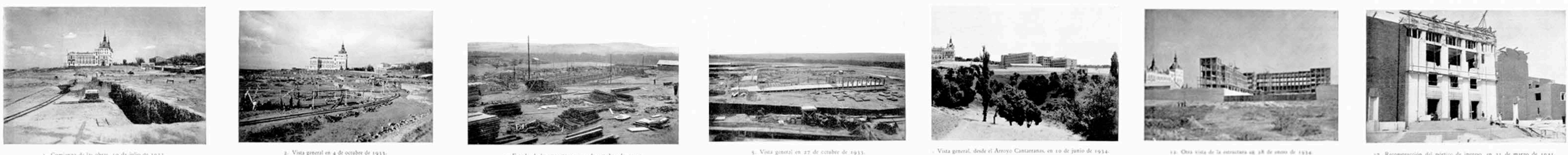
En este capítulo no se nombrarán o especificarán tanto las unidades militares o mandos militares más que lo estrictamente necesario. Al ser una tesis de proyectos arquitectónico, su objetivo es fundamentar los procesos proyectuales de diseño basados en la arquitectura y el entorno. Procesos en este caso concreto, apoyados en teorías y conceptos militares, ya que en parte por éstas surgieron la mayoría de las modificaciones que trasformaron el terreno, el proyecto, el paisaje y el lugar sobre el que nuestro estudio se asienta. 
CAP3 _ FÍSICO [LO AJENO] _ TRASFORMACIÓN.

La Ciudad Universitaria, no fue sólo un campo de batalla sino un lugar periférico urbano que se convirtió en una zona fortificada e impenetrable durante los más de dos años de confrontación. El lugar que había absorbido un proceso proyectual de carácter docente y universitario por una acción ajena y sin precedente, lo trasformó en un lugar nuevo, absorbiendo un nuevo proyecto, unos nuevos paisajes circunstanciales y temporales.

Aunque tenemos muchos comandantes capaces de hacer marchar una división de soldados por un parque, jni siquiera uno de ellos sabe lo suficiente de tácticas militares como para poder sacarlos de allí! 1

Winfield Scott

${ }^{1}$ El general Winfield Scott, sirvió al ejército de los EEUU y fue diplomático y candidato a presidente de su país. 


\section{C.3.1_La escuela de La mirada. Un paisaje bélico - arquitectónico.}

El paisaje es, [...], algo subjetivo, se trata de una interpretación realizada sobre una realidad, el territorio, que viene determinada por la morfología de sus elementos físicos, pero en la que intervienen factores estéticos, que le unen a categorías como la belleza, lo sublime, lo maravilloso y lo pintoresco, y a factores emocionales, que están estrechamente vinculados con los estados de animo con las experiencias de quienes contemplan. ${ }^{2}$

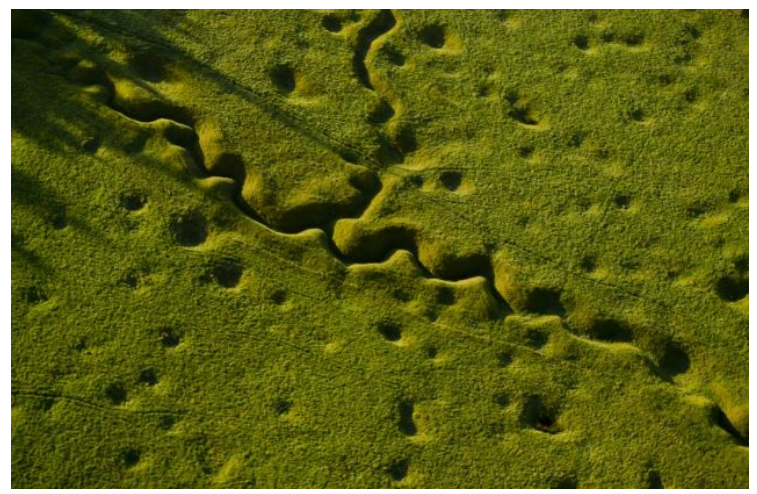

"Trincheras e impactos de artillería son aún perfectamente visibles en los verdes campos de Somme" Michael St. Maur Sheil Imagen de la revista "Smithsonian", 2014

El paisaje, como extensión que se ve desde un sitio, es lo que se ve al contemplar una superficie, al contemplar un territorio o un país. Es una palabra de la que deriva el termino país/paisa-je. El paisaje, aunque es un terminó antiguo y ambiguo a la vez, no existe en todas las culturas, algunas carecen de este concepto y otras lo han adoptado bastante tarde, como la nuestra. El paisaje, no es meramente el entorno, la naturaleza o el territorio, es un concepto que llega de Oriente en el siglo XVI y surge cuando el hombre deja de mirarse a sí mismo como centro del universo y mira al mundo que lo rodea. “...mirar con un proceso, esfuerzo y técnica."3

De acuerdo esta teoría, se puede llegar al disfrute de la contemplación de un paisaje y generar unos sentimientos propios, pero requiere de un aprendizaje para mirar de manera diferente. Es lo que Maderuelo llama, a lo largo de la mayoría de sus libros sobre el paisaje, "La escuela de la mirada". De esta escuela proviene el origen de lo que se empezó a llamar paisaje; paisaje íntimamente unido a lo pictórico, porque fue en los cuadros y en la pintura donde se dieron las primeras representaciones de esta palabra, de este concepto, hasta aparecer escrita por primera vez, y tomar así significado propio dentro de la pintura. Mucho más tarde

\footnotetext{
2 Maderuleo, Javier y Rivera Blanco, Javier. Arquitectura: paisaje y patrimonio en la Comunidad de Madrid:[exposición]. Servicio de Publicaciones de la Universidad de Alcalá, 2011. p.21 ${ }^{3}$ Ibídem. 
y casi en la contemporaneidad, sería la disciplina arquitectónica quien adaptaría este término a sus propios intereses, estudios o investigaciones.

La ciencia se ha apoderado, en parte, de ese paisaje, que empezó siendo puramente pictórico, y es ahora calificado por los geólogos, biólogos o geógrafos con un vocabulario puramente científico por sus capacidades geológicas, agrarias, biológicas etc. pero sin olvidar, que estos paisajes siguen teniendo o poseyendo unas cualidades formales, estéticas y plásticas como las de aquellos cuadros que aprendimos a mirar...

Según Javier Maderuelo, los arquitectos a lo largo de la historia se han "autorreferenciado" y no se han relacionado con su entorno o su medio físico; una ceguera que llevó durante mucho tiempo a planificar ciudades inhóspitas, a construir lugares con falta de identidad o a la destrucción de lugares de gran valor ambiental a favor de lugares construidos sin ningún valor arquitectónico ni urbanístico, no relacionando su obra con el paisaje que la rodea.

En este proceso en que los artistas han sido cada vez mas sensibles en la contemplación del paisaje, y mas diestros en la trasmisión de la emociones surgidas frente a él, a la vez que los científicos han desarrollados infinidad de técnicas para valorar el territorio, su actividad y sus capacidades, los arquitectos parece que se han encerrado en un lenguaje autorreferente que se justifica a si mismo sin necesidad de relacionarse con el entorno en lo que enclava sus producciones: las edificaciones ${ }^{4}$.

Sin embargo, en algunas "ramas" del paisajismo, como fue en el caso de Olmsted, uno de los primeros arquitectos paisajistas que trabajó con Calvert Vaux, ${ }^{5}$ arquitecto de profesión, se veían capacitados a relacionar las construcciones, edificios y encargos con el entorno que los rodeaba, con el diseño de sus jardines, parques públicos y zonas aledañas. Incluso a modificar y cambiar el terreno con capacidades estéticas, compositivas y técnicas. A diferencia de los arquitectos, los arquitectos paisajistas llegaron mucho antes a entender, observar y valorar los paisajes; pero fueron los arquitectos los que supieron, en un momento, añadir este valor a su obra, valor intrínseco en su manera de proyectar y elaborar sus obras, sin entenderlo, como una cualidad adicional, sino como algo natural. Con la capacidad de no solo mirar, observar y contemplar, sino ahora también de modificar.

Las interpretaciones que se dieron a esta disciplina o denominación fue el termino "La arquitectura del paisaje", siempre resultando compleja y contradictoria la

\footnotetext{
${ }^{4}$ Maderuleo, Javier y Rivera Blanco, Javier. Op. cit. p.26

${ }^{5}$ Arquitecto y paisajista británico, diseñó el Central Park de Nueva York junto con Frederick Law Olmsted.
} 
relación entre las palabras, pareciendo que no pueden convivir una al lado de la otra. Una por su carácter estático o artificial (arquitectura) frente a la otra por su carácter dinámico y natural (paisaje). No siempre han sido bien entendidas y hasta hoy la mezcla y utilización de ambas palabras de manera conjunta o en amplio sentido sigue dando lugar y alimentando a una mayor confusión sobre el tema.

En 1858 es Frederick Law Olmsted, el diseñador del Central Park de Nueva York, quien acuñó el termino "arquitecto del paisaje". Por primera vez estas dos disciplinas, que podrían considerarse antagónicas (Artificial-Natural), empiezan y se utilizan unidas, pero no con la misma precisión ni significado en todos los países. Escogió este término, este concepto y demostró razones para hacerlo merecedor basándose en su productiva y extensa carrera en el diseño de parques, espacios urbanos, infraestructuras, redes de circulación, modelos de tramas urbanas, zonificaciones, propiedades particulares y en particular en campus universitarios. Sus conocimientos en arquitectura e ingeniería, su facilidad para, dirigir y organizar le hicieron ser el maestro que otros que le imitaron como Horance Clevelan ${ }^{6}$ o Charles Eliot ${ }^{7}$. Sin embargo, pronto empezaron las pugnas por ámbitos comunes con otras profesiones como biólogos, ingenieros, topógrafos y urbanistas, que dieron lugar mas tarde a la mal entendida "arquitectura del paisaje".

Para Olmsted, bajo su criterio y pensamiento, la "arquitectura del paisaje" era el contacto con el paisaje natural, era la esencia para la moralidad, la salud y la felicidad del hombre8. Sin embargo, poco tiempo después, para Gareck Eckbo ${ }^{9}$, paisajista posterior a aquel, la definición se complica y se amplia. Es aquella parte del paisaje que el hombre desarrolla y conforma mas allá de edificaciones, carreteras o servicios y hasta incluyendo la misma naturaleza salvaje. Aunque el término se diseña como un espacio para que viva el hombre, es una ampliación de la arquitectura por otros medios, pero son el mismo trabajo. Por tanto, las diferencias entre arquitectura y "arquitectura del paisaje" no es tanta sino en los materiales, las técnicas y la obra en que se ejecuta; no tanto en el proceso o forma

\footnotetext{
${ }^{6}$ Horace William Shaler Cleveland (1814-1900) fue un arquitecto paisajista americano. Su conocimiento del paisaje natural y del diseño, su teoría de la observación directa y el estudio de la naturaleza a través del dibujo y la cartografía, se pueden comprobar en toda su obra, entre lo más conocida, el cementerio de Sleepy Hollow en Concord, Massachusetts.

${ }^{7}$ Charles Eliot (1859-1897) fue un arquitecto paisajista , conocido por ser pionero en la planificación regional y sentar las bases de zonas de conservación en todo el mundo. Él fue uno de los participes en la configuración del Sistema del Parque Metropolitano de Boston, diseñado una serie de paisajes públicos y privados, y escribió ampliamente sobre variedad de temas relacionados con el paisaje y el planeamiento.

${ }^{8}$ Laurie, Michael. Introducción a la arquitectura del paisaje, GG, 1983. p.23

${ }^{9}$ Arquitecto paisajista estadounidense conocido por su libro Paisaje para la Vida escrito en 1950. Tras estudiar en Harvard y Berkeley, asistió a clases en el Bauhaus con Gropius como director. 
de actuar, pensar y analizar. Pero frente a una arquitectura abstracta, separatista y autónoma, la arquitectura del paisaje pretende desarrollar la obra arquitectónica creativa siempre a favor y en relación al entorno y las cualidades del territorio que la rodea. Y en un campus universitario se podrían unificar todas estas relaciones.

En las últimas tres décadas del pasado siglo XX este concepto se expandió y se popularizó, empezando a ser objeto de estudio y trabajo por parte de los arquitectos, viéndolo como una ampliación a su trabajo de mera construcción edificatoria. Ahora es mucho mayor la pugna que se desarrolla con los urbanistas, paisajistas, biólogos, geógrafos, ingenieros agrónomos, civiles o incluso jardineros. La arquitectura del paisaje y el paisaje arquitectónico se nos muestra como un conjunto de ambos conceptos.

...es un concepto que hoy se halla relacionado con la ordenación del territorio, el proyecto urbano, las trasformaciones geográficas, la gestión de recursos turísticos, la preservación de sitios históricos, la regeneración social de regiones deprimidas un largo etcétera de actividades... ${ }^{10}$

Es por todo ello que el término paisaje, en su desarrollo durante la modernidad ha sido mayormente relacionado con la pintura, con la geografía o con la ecología. Sólo en un época más actual y reciente se han involucrado en él, los estudios técnicos de arquitectura o el urbanismo. El interés que ahora tiene el paisaje, olvidándonos de lo turístico, tiene su razón en niveles quizá mas intelectuales, profesionales incluso filosóficos. Se ha ampliado su forma de estudio, pero también se ha perdido su relación de referirse a algo concreto y preciso. Por eso, a veces, el amplio abanico al que se refiere la palabra paisaje, tiene algo más de negativo que de positivo, ya que es casi imposible dar o enunciar una definición general de la palabra "paisaje" en sí misma.

En esta tesis, el término "paisaje bélico-arquitectónico", se utilizará para integrar en él, el recuerdo de lo que fue el lugar de estudio; un proceso y transición, que tanto arquitectónica como paisajísticamente, fue una acción de transformación, cambiando de uso y de apariencia. Un cambio drástico del lugar y de la mayoría de las construcciones allí enclavadas.

Aunque se utilice la palabra "paisaje" desde su concepción más generalista o común, el análisis y la reinterpretación de nuestro ámbito de estudio, dará lugar a la definición de procesos (acciones) de cambio en el proyecto que desdibujaron el proyecto inicial, dándole temporalmente otro uso. Una forma al proyecto de fortificación que se generó sobrepuesto. La mayoría de las destrucciones, desde distintos puntos de vistas físicos o memorísticos, fueron de carácter puramente

10 Maderuleo, Javier y Rivera Blanco, Javier. Arquitectura: paisaje y patrimonio en la Comunidad de Madrid:[exposición]. Servicio de Publicaciones de la Universidad de Alcalá, 2011. p.29 
físicos de lo que allí se había construido como un campus o recinto universitario hasta ese momento. Pero generaron una huella particular en las edificaciones y en su concepción o relación con el lugar en donde estaban enclavadas.

...la idea más general del paisaje se ve unida a la sensación de disfrute en la apreciación de la imagen de un territorio. ${ }^{11}$

\section{UN PAISAJE BÉLICO - ARQUITECTÓNICO.}

Las zonas devastadas y arruinadas, a las que hace referencia Iñaki Ábalos en su libro "Campos de Batalla", son aquellas que fueron descubiertas, renombradas y calificadas por Robert Smithson ${ }^{12}$ como zonas o áreas "entrópicas (antiguas minas, silos abandonados, vertederos, zonas industriales olvidadas y deterioradas) ${ }^{13}$ ". Aquellos paisajes o áreas que dieron lugar a un nuevo paisaje hasta ese momento desconocido y antes no valorado. La admiración de Smithson por aquellos paisajes industriales en ruinas era parecida al interés por los vacíos y los márgenes urbanos de algunos arquitectos coetáneos suyos de aquel momento. Son estas áreas, las que Ábalos toma de punto de partida en su libro, que dará lugar a un trabajo posterior de investigación. Un proyecto de redes a nivel territorial basado en los lugares que en la geografía peninsular habían sido testigo de las mayores confrontaciones.

Las ruinas y los restos de épocas pasadas siempre han sido objeto de admiración o estudio, lugares admirados o estudiados no solo por su condición urbana sino épica, dramática o monumental. Hechos que se podrían encontrar en ellos y que Ábalos en su libro se remarca desde el principio.
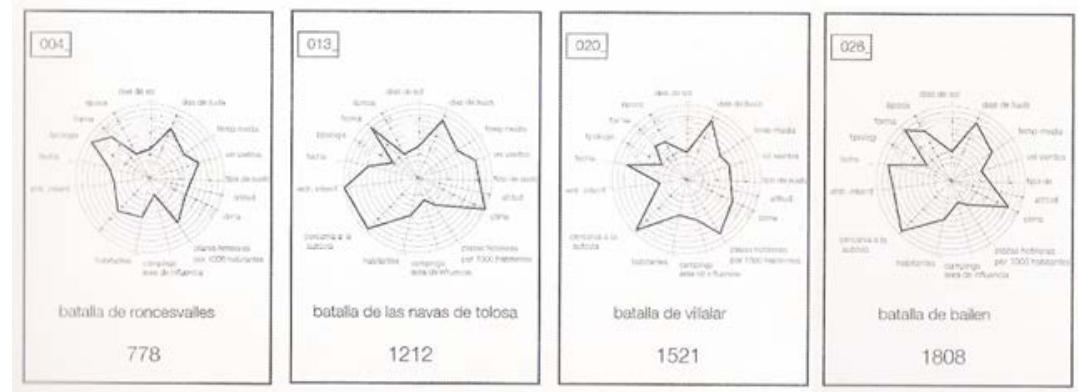

Fig.1. Representación fichas "campos de batalla". Libro "Campo de Batalla p. 133

\footnotetext{
11 Maderuelo, Javier . “Aquello que llamamos paisaje”. Visions, Diciembre 2003, núm. 2 p.20-21

12 Robert Smithson, artista estadounidenses relacionado con el movimiento Land Art.

${ }^{13}$ La entropía es la medida del desorden y del caos progresivo. La palabra entropía procede del

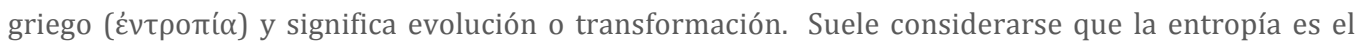
desorden de un sistema, es decir, su grado de homogeneidad.
} 
...como un paisaje de la memoria, ..., lleno de potencias multidireccionales por explorar. ${ }^{14}$

Volviendo a Smithson, y a su obra "Los monumentos de Passaic", el artista utilizó la metodología de tomar fotografías de los restos industriales, y por medio de éstas, reinterpretaba los suburbios de su lugar de nacimiento, siguiendo la idea de la mirada pintoresca. Buscaba la dialéctica del paisaje abandonado.

Las ruinas industriales que R.S. encuentra allí pasan a llamarse inmediatamente "monumentos", con todo el contenido que el término implica. Los artefactos industriales en desuso, tuberías, grúas, depósitos, etc., adquieren una dimensión monumental y heroica y se convierten en los nuevos hitos de la cultura post-industrial, en una continuación, quizás, de la idea duchampiana de santificar los objetos y las cosas que encontramos alrededor. Esta glorificación de las ruinas industriales podría tener su origen en esta línea, que de Duchamp pasa a los artistas Pop, y que Smithson comenta en el texto "Robert Smithson on Duchamp".15

De la misma manera que los paisajes abandonados y olvidados fueron admirados, los lugares y espacios bélicos, también podrían haber llegado a ser similares a los anteriores, no por el hecho de su condición monumental y heroica, que lo tendrían intrínseco, sino más por su condición de hito. Más si cabe, cuando de algunos de esos paisajes se desconoce de su existencia y otros han empezado a cobrar importancia y a ser valorados a raíz de nuevas interpretaciones y estudios. Pueden pasar como lugares desconocido, para las personas que los contemplan o caminan por ellos, pero el carácter paisajístico de su entorno, su valor constructivo y el haber sido testigo mudo en el pasado de un hecho histórico bélico, les dan un valor diferente. Estos nuevos valores artísticos y paisajísticos fue una parte de lo que descubrió Virilio ${ }^{16}$ en los bunkers y los elementos de hormigón armados en la zona del desembarco de Normandía durante la 2a Guerra Mundial. Eran los vestigios de una arquitectura bélica que comenzaba a ser entendía y valorada por la población tanto por su valor escultórico como por su concepción de ruina y algo propio en el lugar. Tanto Virilio como Smithson fueron los primeros en "mirar" a estas piezas arquitectónicas o elementos del paisaje, con una nueva "intención" en la búsqueda de nuevos significados.

\footnotetext{
14 Ábalos, Iñaki "Campos de Batalla”. Liga Multimedia Internacional .COAC. p. 8

${ }^{15}$ García-Germán, Jacobo. Los diez paisajes de Robert Smithson. Septiembre 2002. (Comentarios sobre algunos textos). Texto publicado en Circo № 98. M.R.T. Coop.

16 Paul Virilio, urbanista y filosofo francés, realiza en su libro Bunker Archeology, una taxonomía y reinterpretación conceptual de los bunkers, refugios y casamatas construidos durante la Segunda Guerra Mundial en la costa francesa.
} 

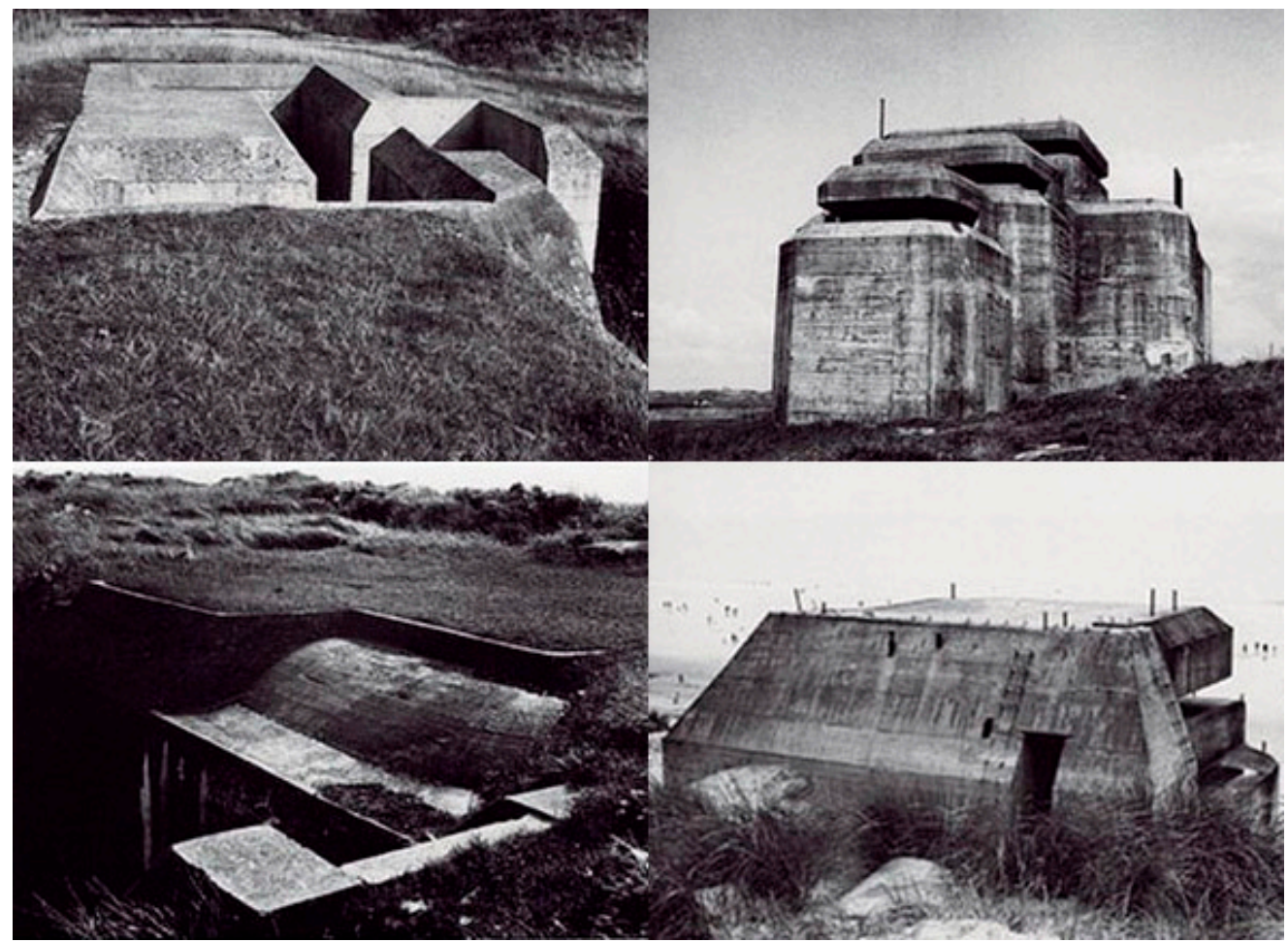

Fig. 2. Fotografías "Series and Transformation "Bunker Archeology " de Paul Virilio p. 162-149

Pero si hay que volver a "mirar" y "descubrir" los paisajes bélicos, de batalla, ofensivos o defensivos, de nuestro ámbito de estudio, se tiene que destacar el problema o la casuística de que no son visibles. Estos paisajes bélicos ya no están, han sido borrados, han desaparecido. Quedan solo en la memoria. Fueron de nuevo trasformados, con las reconstrucciones de la Universidad que tenía que volver a dar servicio a la población de la ciudad y para lo que, realmente, había sido construida. La mayoría de esas construcciones medio en pie, ruinas, escombros y restos de calles, viales o infraestructura se perdieron $y$ desaparecieron con el doble objetivo de olvidar y borrar, quizá para no recordar ni convertir ese lugar en zona de peregrinación o visita, o para hacerlo, como así se hizo, por medio de otros elementos más simbólicos o monumentales.

Todo lo que allí se construyó y a la vez se destruyó durante los años de confrontación (de noviembre 1936 a abril 1939), se realizó como algo ajeno al proyecto universitario (proyecto arquitectónico y urbano) que allí se estaba proyectado y construyendo. AJENO ${ }^{17}$, porque si hablamos de paisaje o arquitectura bélica en la Ciudad Universitaria de Madrid, hay que hablar de fortificación y arquitectura defensiva u ofensiva. Una acción de fortificación rápida y necesaria que se originó sin tener en cuenta el valor y proyecto arquitectónico o paisajístico

17 Según la RAE. (Del lat. aliēnus, de alı̌us, otro). 1.adj. Perteneciente a otra persona. 2.adj. De otra clase o condición. 3.adj. Distante, lejano, libre de algo. Ajeno de cuidados 4.adj. Impropio, extraño, no correspondiente. 5.adj. Que no tiene conocimiento de algo, o no está prevenido de lo que ha de suceder. 
del lugar, algo obvio ante un hecho como una guerra, pero con la peculiaridad que en dicho lugar, utilizándose todos sus valores formales, constructivos y espaciales, se llevó a cabo unos objetivos determinados muy diferentes al uso didáctico y docente. Un lugar que absorbió todo un proyecto nuevo, sin estar mucho menos previsto pero quizá de alguna manera si preparado, o con capacidad de adaptación, para lo que habría de acontecer durante los dos siguientes años. ${ }^{18}$

Durante el estudio de esta trasformación que se produjo del recinto universitario, a partir de un proyecto de campus a un completo y ajeno proyecto de fortificación, nos adentramos en la idea de unir o ligar paisaje, memoria bélica, proyecto y arquitectura. La idea de estudiar las consecuencias de una serie de hechos y decisiones que cambiaron el proyecto, uso, función y diseño del campus universitario, convirtiéndolo en un campus de batalla. El proyecto arquitectónico y urbanístico previo diseñado y construido quedaría como base y sustento de un nuevo proyecto de fortificación.

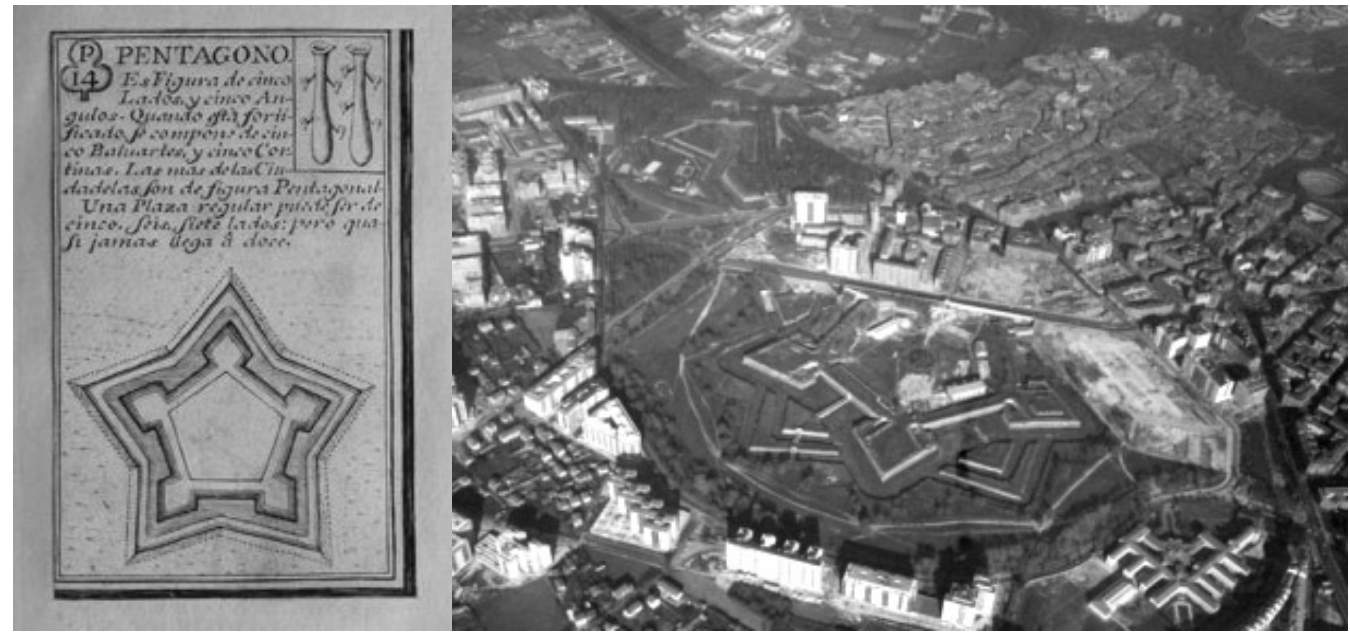

Fig. 3. Juego de la Fortificación. Madrid: Pablo Minguet Yrol, ca. 1733. 49/49

Fig. 4. Fortificación Ciudadela y murallas de Pamplona. Archivo municipal.

Según Steen Eiler Rasmussen, en su libro Ciudades y edificios. Descritos con palabras y dibujos, una ciudad no solo se vuelve regular cuando se convierte en un templo, sino que si un grupo se enfrenta a la necesidad de crear una nueva ciudad en un lugar extraño y desconocido, la levantaran de acuerdo a un plan preconcebido, o bien terminará siendo un caos.

$Y$ ese plan será, por necesidad, muy simple y estará fácilmente trazado, de tal modo que todos puedan descubrir rápidamente que tienen que hacer con la menor confusión posible. ${ }^{19}$

18 Será necesario, durante el desarrollo de este capitulo, utilizar algunos conceptos y palabras básicas mas propias de otras disciplinas, históricas o bélicas, para poder comprender los procesos de trasformación proyectual.

${ }^{19}$ Eiler Rasmussen, Steen Ciudades y edificios descritos con palabras y dibujos. Reverté, 2014 p.44 
Asemeja la construcción de las ciudades a como los soldados organizaban sus campamentos en largas filas rectas dentro de una superficie, para que la vigilancia y la defensa fuera lo mas fácil y eficaz o relaciona el tamaño y la escala de la ciudad de la antigüedad, en función de la capacidad de abastecer con comida a la población de su interior. Utiliza la Ciudad de Turín como ejemplo de cómo se introducen las murallas y los bastiones en la planta previa romana. Una la fortificación poligonal irregular a modo de protección del espacio interior, desarrollándose en etapas o líneas sucesivas perimetrales durante el Renacimiento. Sera esta época, cuando surge a su vez la idea de ciudad ideal, trazada u protegida, como un todo independiente y equilibrado para una vida en comunidad bien protegida contra cualquier agresor. La aparición de nuevas armas y la aparición de la pólvora, serian los verdaderos causantes de la trasformación de las ciudades ideales con saliente, muralla y bastiones en su perímetro.

Se comprobó que el contorno regular de las ciudades era el menos practico para la fortificaciones de murallas con bastiones, ya que dejaban flancos y zonas sin cubrir visualmente y los propios bastiones en las esquinas dejaban zona expuestas fácilmente a ser batidas o disparadas. Un pentágono era mejor que un rectángulo, y cuanto mas perímetro urbano poliédrico mejor.

Aparecieron por esto, gran cantidad de libros, tratados y nuevas teorías sobre la fortificación y la defesa de la ciudades, ya que el sistema defensivo era incuestionable en el diseño de una ciudad ideal, y cuanto mas poligonal fuera la muralla, también la ciudad debía tener muchos lados.

Nunca antes se habían escrito tanto libros sobre proyectos de ciudades ideales. La mayoría en Italia, libros entre la técnica y le arte, entre ello el de Franceso di Giorgio donde se representa una serie de ciudades ideales como mezcla de imaginación, técnica y teoría, fruto de sus conocimientos en arquitectura y constructor de fortificaciones.

En sus diseños las plantas de ciudades se basaban en el polígono de fortificación perimetral y la plaza central. La zonas intermedias estaban rellenadas de diversas maneras mallas geométricas de callas y plazas entorno al espacio central. 
Lo importante era el perímetro y el espacio central como núcleo de conexión entre la s partes, el espacios sobrantes eran retales y no tendría interés. ${ }^{20}$. De esta manera podemos entender cómo la idea de resguardo seguía vigente en cuanto a la protección de grandes masas de población. Las ciudades se tenían que defender de los ataques de enemigos y las murallas cumplían en gran medida este requerimiento, el funcionamiento de fortificación.
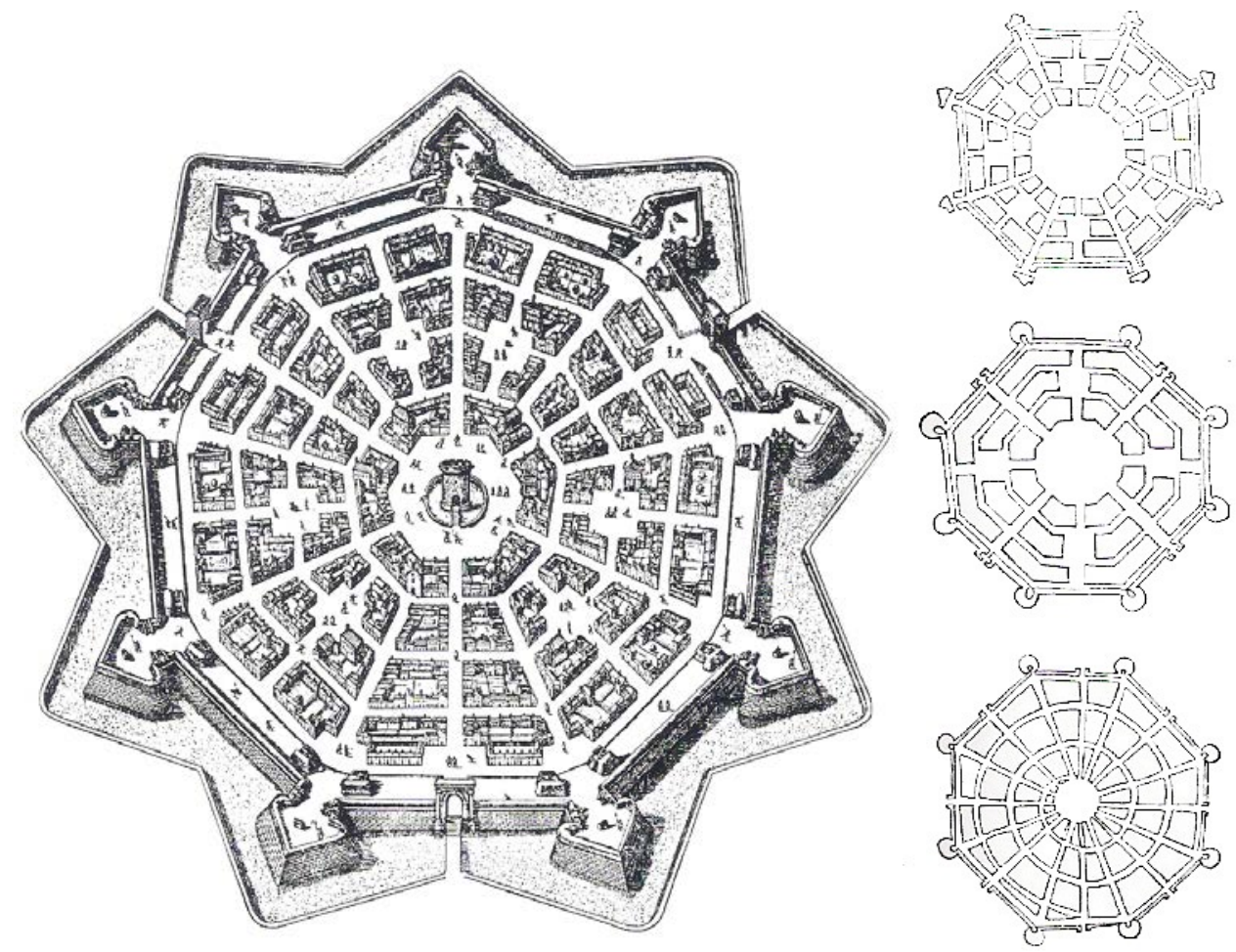

Fig. 5. Fortificación y Planeamiento Ciudad Palmanova 1593.

Fig. 6. Plantas ciudades Ideales Renacimiento 1500.

\footnotetext{
20 El ejemplo mas claro de ciudad ideal sería Palmanova, construida en 1593, con una muralla central de nueve lados y tres calles radiales que llevan hasta el centro. Las calles son anillos concéntricos y radiales con un edificio situado en el centro.
} 


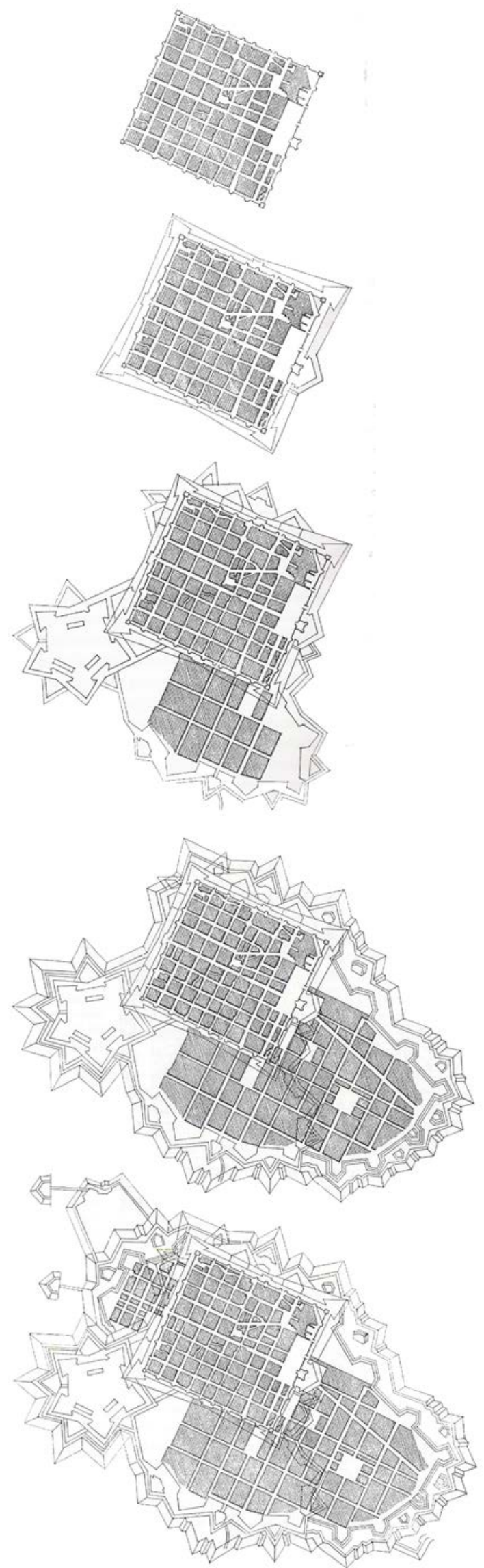

Fig. 7. Fortificación ciudad de Turín. Etapa Romana, , XVI, XVII, 1670 y finales de XVII. Ciudades y edificios descritos con palabras y dibujos. Reverté, 2014 p.50 y 51. 


\section{C.3.2 Metamorfosis del campus de Madrid.}

La fortificación es un fenómeno constructivo híbrido entre arquitectura e ingeniería militar y debe ser entendido teniendo muy presente el momento, el dónde y el cuándo se ha llevado a cabo. Es una acción militar por la que se prepara y se organiza el terreno para el combate y la resistencia, por medio de construcciones y trasformaciones localizadas para favorecer la acción de la lucha, dificultar el avance del enemigo y protegerse de los ataques de estos. 21

La fortificación es por tanto un tipo de proyecto edificatorio, de la disciplina militar más que arquitectónica o urbanística, pero en nuestro caso de estudio se puede entender en parte como tal, como arquitectónica pero con diferente fin que el habitual. Hay dos tipos de fortificaciones que es necesario que distinguir:

- Las fortificaciones permanentes: ejecutadas en época de paz o de entreguerras permitiendo la protección y la seguridad infranqueable de las fronteras. Se construyen con materiales duraderos para un tiempo ilimitado.

- Las fortificaciones de campaña: realizadas normalmente en zonas expuestas o de frente activo, se hacen por tiempo limitado para defender una posición militar ${ }^{22}$.

Mientras las primeras tienen en cuenta el terreno para favorecer su construcción y analizan las necesidades defensivas o los lugares idóneos de cada posición, las segundas se ven obligadas y condicionadas por las circunstancias de la posición del enemigo y se emplea el terreno tal y como se den las circunstancias.

En el caso de la fortificación organizada y construida por ambos frentes y en ambos lados, en la Ciudad Universitaria de Madrid, fue una fortificación de campaña teniendo en cuenta la fisonomía del terreno y la situación estratégica de la construcciones; la mayoría de ellas perdurarían (a pesar de los grandes destrozos y daños) aunque cambiando su uso ya que el carácter que tomaron durante la confrontación fueron principalmente como bastiones de protección o defensa. Verdaderos actores arquitectónicos en la punta de lanza de bolsa fortificada.

\footnotetext{
${ }^{21}$ Castellano, Ricardo. Los restos del Asedio. Fortificaciones de la Guerra Civil en el Frente de Madrid. Ejército Nacional . Almena. p.21-26.

22 Ver la división y catalogación simplificada de fortificaciones permanentes y de campaña acorde al libro Castellano, Ricardo Los restos del Asedio. Fortificaciones de la Guerra Civil en el Frente de Madrid. Ejército Nacional.
} 
Las edificaciones y construcciones recién terminadas, no siendo construidas para esa necesidad, de protección y resguardo, funcionaron como tal. Los espacios, plazas, las distancias físicas entre ellas, las organización en nuevos grupos, sus formas o estructuras constructivas se convirtieron de manera temporal en verdaderos puntos y zonas adelantadas en la fortificación urbana del campo de batalla. Sin embargo, este tipo de nuevo uso de las construcciones y de trasformaciones del lugar nunca fue motivo de estudio desde le punto de vista arquitectónico o paisajístico, quizá porque la necesidad de reorganización social y urbana fue rápida, y los planos y datos quedaron relegados a archivos militares. Su rápida reconstrucción formal y materia, la huella que quedó en el suelo, se borró y quedó debajo de las modificaciones y reconstrucciones, dando lugar a un nuevo "proceso" que se estudiará mas adelante como suma y consecuencia de los dos proyectos anteriores.

Al estudiar y analizar estos lugares, se han encontrado en ellos unas ciertas cualidades comunes, una épica e incluso dramática condición quizá sacramental. Paradójicamente cuando somos consientes o descubrimos el hecho que ese lugar sufrió, aparece la condición sentimental y memorística que incrementa su valor como un proyecto diferente al resto. En el interior de ese proceso de trasformación conlleva la memoria, la historia, el uso temporal en las acciones militares, estando lleno de energías y tensiones multidireccionales y significativas.

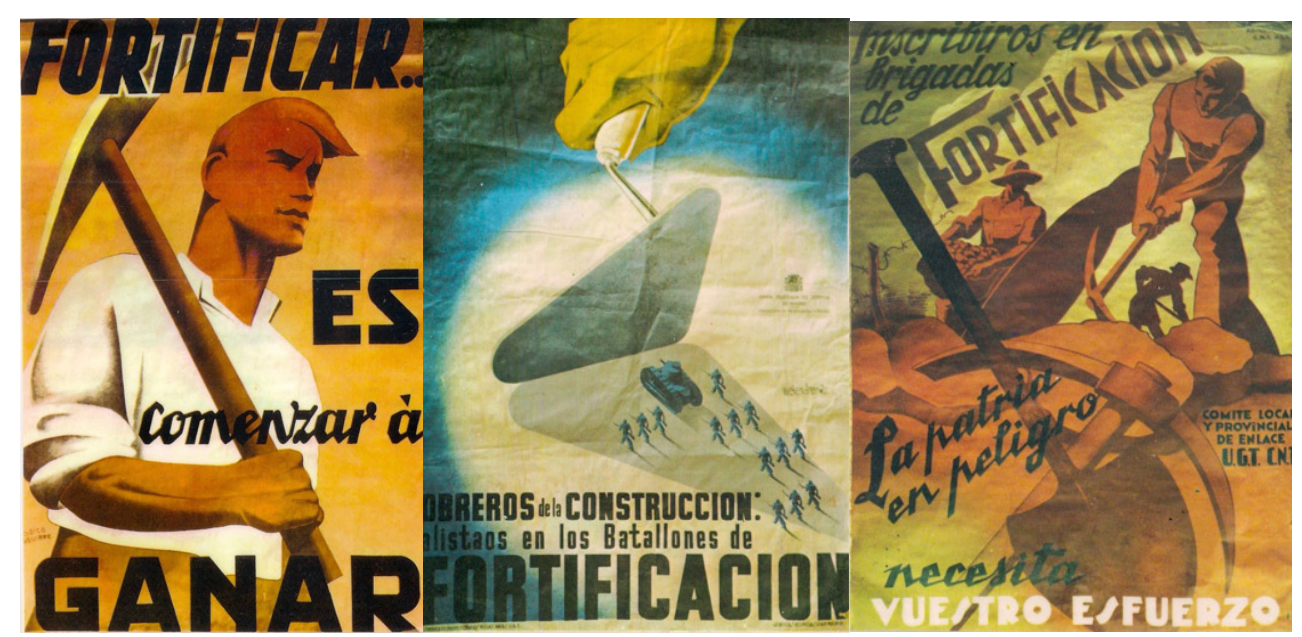

Fig.8. Imágenes de Carteles Publicitarios Republicanos animando al pueblo a participar en la fortificación de la ciudades en el período inicial de la confrontación. 1936-1937

NOTA: Anexo c3_Fortificaciones Permanentes y de Campaña_ Madrid Fortificada 


\section{C.3.2.1_NueVAS formas de ESTUdiar Un PAISAJE belico olvidado.}

Los campos de batalla, son como dice Teresa Galín ${ }^{3}$, en su artículo en el libro anteriormente citado de Iñaki Ábalos, lugares donde se han concentrado unas características comunes, y donde el hecho de la existencia aparece por el hecho en sí de la misma batalla o hecho bélico y su característica máxima es que son lugares que engloban partes de otros lugares. La definición del lugar de la batalla viene determinada por el mismo hecho y nada mas, que trascurre en un periodo de tiempo limitado y concreto, luego desaparece, dejando tras de sí este lugar que intentamos recuperar.

Esta situación distinta y diferente, ayuda a generar una nueva visión y mirada de un lugar determinado, más amplia y con nuevos parámetros a los antes utilizados. Parámetros como conceptos que permiten comprender y analizar distintas ópticas o reinterpretaciones. Conceptos, que en su caso de estudio, fueron definidos a partir de palabras claves como: Posicionamiento, Continuidad, SucesiónMovimiento, Potencialidad, Alteración Perturbación, Fisiología, Cultura y Artificialidad. Es en el mismo libro donde se describen estos conceptos, donde se escogen estos lugares como ámbito de actuación y futuro intervención como proyecto, por estar cargados de energía que se catalizan en futuras posibles actuaciones de proyecto en el tiempo sobre el lugar.

...batallas importantes pueden dar lugar a monumentos que son simultáneamente naturales y artificiales, no solo por lo que implican de proyección de la memoria y de la cultura sobre el territorio sin también porque, carentes de huella visible del pasado, es necesario escenificar para ella un espacio de rememoración que sea capaz de transmitir y evocar esa descarga de energía instantánea en términos paisajísticos. ${ }^{24}$

Hay que ver estos lugares con la característica más propia de poder ser lugares memorables; espacios que a nivel del proyecto pueden soportar o sustentar esas energías generadas por el tiempo $\mathrm{y}$, sobre todo, por la memoria, aunque sus hechos y restos ya no sean visibles. Ideas o afirmaciones que constatan como el paisaje y la arquitectura se pueden fundir en un mínimo gesto. Existirían razones y herramientas para entender el paisaje y la arquitectura de manera diferente a como se hacía hace un siglo. Esas malinterpretaciones y usos de los términos "paisaje" o "arquitectura del paisaje" quizá están llegando a entenderse en este lugar de La Ciudad Universitaria.

\footnotetext{
23 Teresa Galí Ingeniero de agrícola y postgraduada en Arquitectura del Paisaje de la Universidad Politécnica de Cataluña escribe el capítulo “Ochos Palabras Clave” del libro Ábalos, Iñaki Campos de Batalla. Liga Multimedia Internacional .COAC. p. 48

24 Ábalos, Iñaki . Campos de Batalla. Liga Multimedia Internacional .COAC. p. 68
} 
El paisaje bélico, como paisaje que pudo "admirar" o "rememorar" esos "campos de batalla", utilizando un método de análisis, un proceso, por medio del cual, a través de la mirada de arquitecto, se interpretan los valores físicos, geográficos, históricos, perceptivos y emocionales conjuntamente. Reinterpretando lo que ofrece el territorio y su relación con la arquitectura. Buscando el mejor punto de vista de intervención para su lectura e interpretación. Un estudio que continúa, como en los anteriores capítulos, adquiriendo los conocimientos a través de los diferentes estratos y escalas de este lugar, analizando y se separando las variaciones que ha sufrido el lugar con el paso del tiempo y su relación con las circunstancias históricas especificas de un hecho diferente a un proyecto arquitectónico previamente diseñado.

- Observación in situ. El conocimiento de forma directa y experimental del lugar. Aprender a distinguir los aspectos que le diferencian. Lo que se ve, requiere de un aprender a mirar para distinguir las diferencias, lo que no se ve, requiere de imaginar y reelaborar nemotécnicamente sobre el terreno aquello que existió y solo se mantiene en plano. El conocimiento del terreno, de lo que en él sucedió, es algo esencial en la toma de decisiones de los procesos de cambios, capas o rastros subyacentes, a nivel arquitectónico y urbano.

- Estudio de planos, mapas, fotografías, datos y documentos. Toda la documentación del pasado encontrada, se ha utilizado para elaborar hipótesis y resultados en base a mapas, planos, esquemas, apuntes, textos, clasificaciones, cuadros comparativos, vistas y reinterpretaciones, permitiendo explicar la complejidad de aquel proceso de trasformación secuencial temporal de fortificación de un espacio semiurbano.

- Interpretación gráfica de lo analizado e interpretación. La interpretación de los lugares de manera comparativa entre el antes y el después, no se hace de manera subjetiva, se tomarán prestadas técnicas o formas de interpretación de otras disciplinas, técnicas más militares o históricas, para realizar esta parte fundamental de la reinterpretación.

Son procesos que quedaron bien representados en planos, croquis, pinturas, fotografías, documentos escritos e incluso bocetos. Ejemplo de otros métodos de análisis y estudio de la confrontación o las guerras ya se han producido en el pasado. La guerra al igual que la historia se ha explicado, descrito y representado de muy diversas maneras; sobre planos, cartas de navegación y de muy diversas maneras gráficas. Como ejemplo de la representación de la historia, es el famoso 154 
plano Histomapa de John B. Spark un gráfico publicado en 1931, siendo a la vez una infografía a modo de desplegable de $150 \mathrm{~cm}$ que narraba y representaba por medio de colores y columnas, la historia del ser humano a través de los auges y caídas de los imperios a lo largo del tiempo.

De manera similar, a través de la representación de acciones de guerra podemos encontrar diferentes tipos de mapas, cartografías y planos. De los mas representativos es la carta figurativa de 1869 o el mapa de Charles Minard 25 , que describió el avance del ejército de Napoleón (en rojo), su retirada (en negro) desde Niemen a Moscú, representado con precisión y sencillez la relacionando de ese avance y la retirada con la cantidad de hombres, las bajas producidas en relación a la temperatura y la distancia recorrida. Para muchos el mejor grafico estadístico de la historia.

Así de manera también parecida, con la utilización de recursos gráficos realizó Florence Nightingale, en 1858, su representación estadística de las pérdida de vidas del ejército del imperio británico en la guerra de Crimea, en relación a las condiciones de higiene en los hospitales y no tanto por las heridas sufridas en la batalla ${ }^{26}$. En su informe "Notas sobre la salud, eficiencia y administración de la armada británica" 27 , dividió las pérdidas en tres clases: en rojo, muerte por heridas; en azul, enfermedades infecciosas, en negro, todas las demás causas; aunque no contaban nada nuevo, hacían clara la inmediata necesidad de una reforma sanitaria lo que se extrapoló a cada hospital inglés y dio lugar a la reforma sanitaria

En el proceso de génesis he organizado y estructurado una ciudad por zonas o grupos de acuerdo a disciplinas, ejes de comunicación o espacios de relación, todo ello se trasformó o modificó la agrupación, disposición y posiciones basándose en un orden más territorial y con carácter defensivo u ofensivo. Mientras que los viales que accedían y comunicaban a las edificaciones habían sido hasta ese momento lineales, ortogonales o radiales, mutaron a un laberinto ramificado, orgánico y adaptado a la topografía. Mientras el terreno se allanó y se realizaron desmontes para conseguir la mejor cota homogénea, las zonas altas, los montículos y las vaguadas servirían de protección, cambiando su objetivo inicial.

Con el análisis anterior en del proceso de génesis (descrito en el capítulo 2) del campus más la implantación del proyecto de fortificación, encontraremos una

\footnotetext{
25 Charles Minard (1780-1870),ingeniero civil francés que realizo sus mayores avances y logros en la realización de cartas y gráficos informativos.

${ }^{26}$ Diez veces más soldados morían de enfermedades que de heridas de batalla.

${ }^{27}$ Nota en Matters affecting the health, efficiency and hospital administration of the British Army.
} 
ciudad nueva urbanizada, que era en el fondo aquella ciudad docente, de caminos, edificaciones, viales y espacios, pero utilizada y generado por una necesidad de confrontación y estratégica, creando a su vez una ciudad subterránea, rasante y fortificada, de edificaciones-fortaleza y viales ramificados.
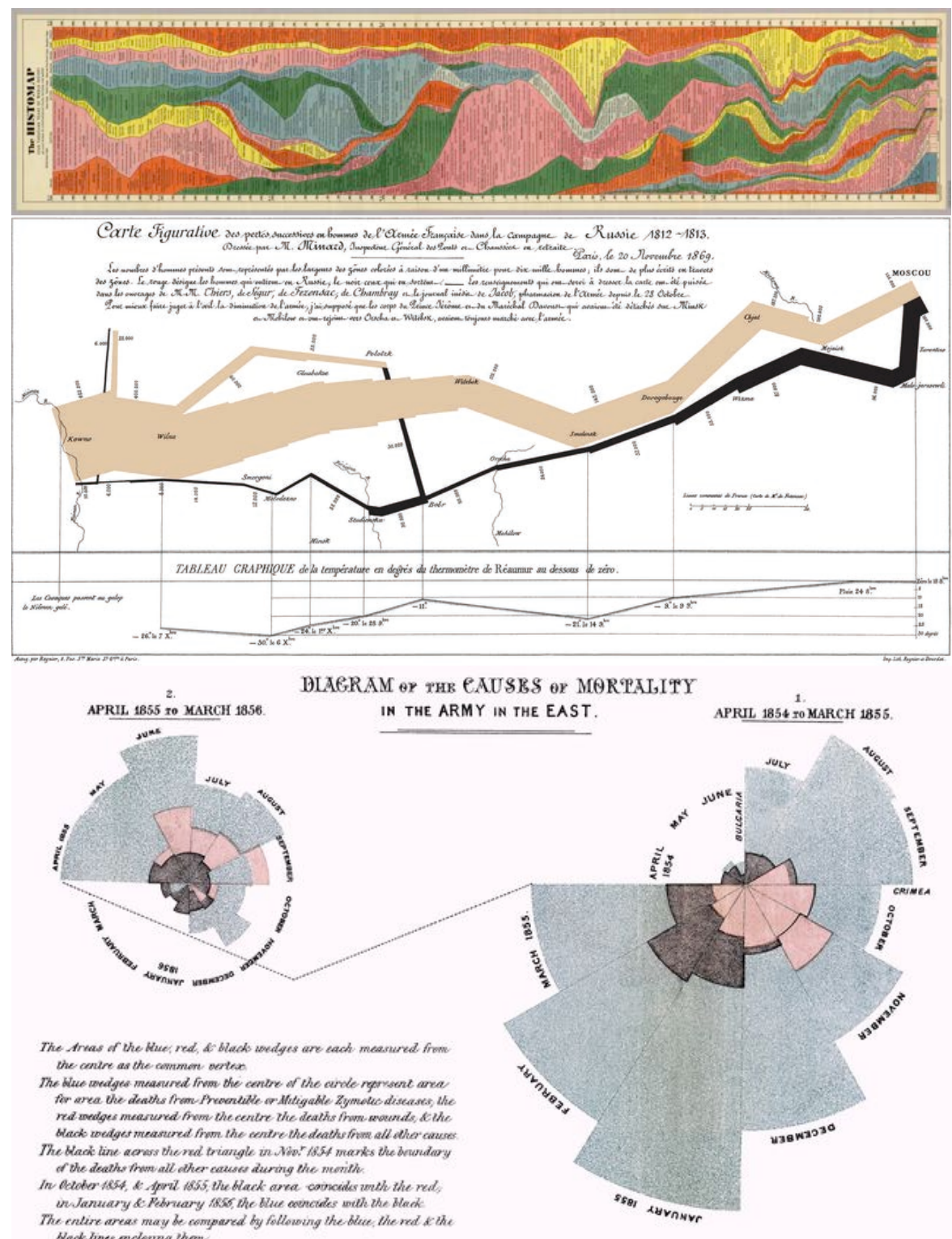

Fig. 9, 10, 11. Imágenes de Histomap, de las Cartas de Minad. y las Rosas

El caminar por la geografía bélica de nuestra guerra produce un sentimiento de evocación, de tristeza y de curiosidad a la par. No debemos perder de vista que aunque ahora sean mudos centinelas de una posiciones inexistentes, los restos de guerra también son la prueba de la irracionalidad a la que pueden llegar los hombres. Y como tal hay que preservarlos. Para que nos recuerden lo que no debemos repetir"z8.

${ }^{28}$ Castellano, Ricardo. Los restos del Asedio. Fortificaciones de la Guerra Civil en el Frente de Madrid. Ejercito Nacional. Almena. p.30 


\section{C.3.3.2_LUGARES ESTRATÉGICOS, TÁcticos Y LOGÍSTICOS}

Como se explica en el libro El Arte de la Guerra29:

Todo el Arte de la Guerra se basa en el engaño. El supremo Arte de la Guerra es someter al enemigo sin luchar.

En el caso de la batalla de Madrid la teoría del engaño solo se aplicó en parte, fue "necesario" luchar por la conquista o la defensa de la capital. Una lucha bajo técnicas militares acordes a la época en la que se produjo. Técnicas militares que se distinguen de tres tipos: la estrategia, la táctica y la logística. Cada una de ellas, influirá y nos llevarán a descubrir diferentes formas de trasformaciones del lugar.

- La Estrategia (diseño): técnica militar que se basa en el análisis de las condiciones del enemigo, tiempo, terreno y medios, con el fin de establecer el uso más eficiente de las propias tropas, para conseguir un objetivo y lograr la derrota del adversario, con el menor costo humano, de material, y económico posible. Es el conjunto de acciones planificadas y coordinadas en el tiempo que se llevan a cabo, para lograr un determinado fin o misión.
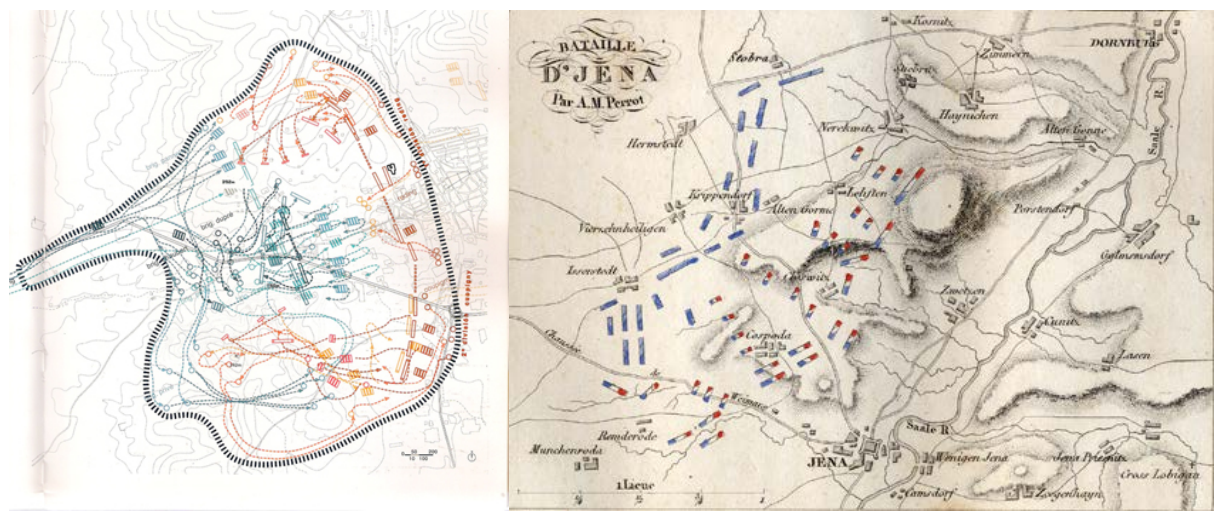

Fig. 12. Representación Batalla de Bailen ". Libro "Campo de Batalla Pág. 25

Fig. 13. Planos de juego de batallas militare (Waterloo y Jena /Don Benito)

- Táctica (medios) - Operaciones: es la parte de la técnica, que trata sobre el empleo de los medios de acción en el campo de batalla. Es el método o forma, empleado con el fin de tener un objetivo. La táctica, forma parte de la estrategia, pues es el conjunto de medidas y métodos que la llevan acabo.

\footnotetext{
${ }^{29}$ Es uno de los mejore libros clásicos chinos, sobre la práctica militar y la estrategia suprema. Escrito por Sun Tzu, fué un general chino del siglo $\mathrm{V}$ ad J.C. Todas sus recomendaciones son de aplicación en momentos de confrontación de naturaleza humana. No es, por tanto, un libro sobre la guerra; es una obra para comprender las raíces de un conflicto y buscar una solución.
} 

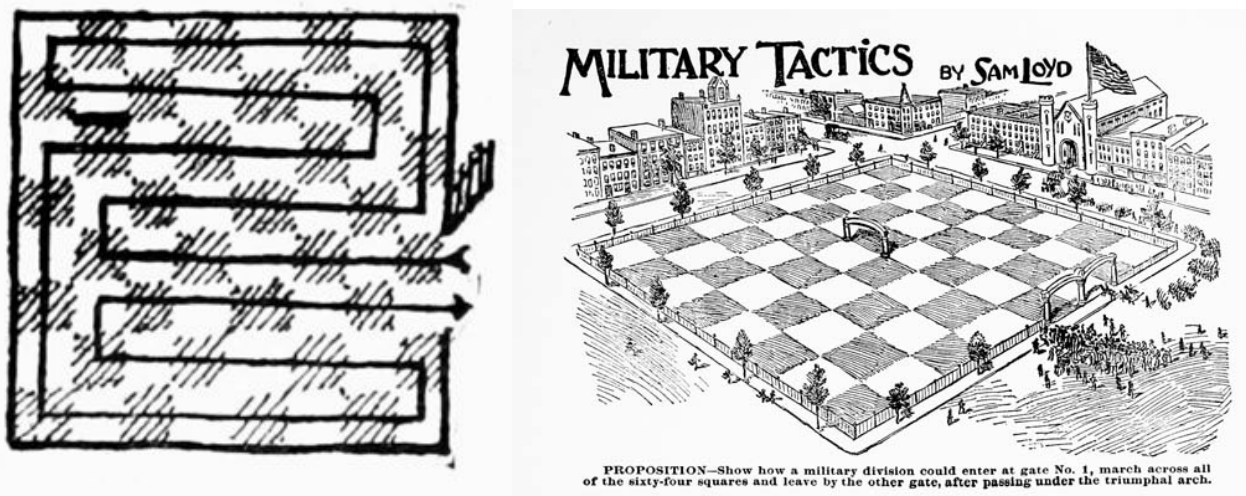

Fig. 14. Planos de juego de táctica militar.

- Logística (apoyos): es la capacidad de mover los ejércitos, los materiales. Los expertos en esta técnica, determinan cómo y cuándo movilizar determinados recursos en los lugares donde son necesarios. Lo importante es mantener las líneas de suministro propias e interrumpir las del enemigo.
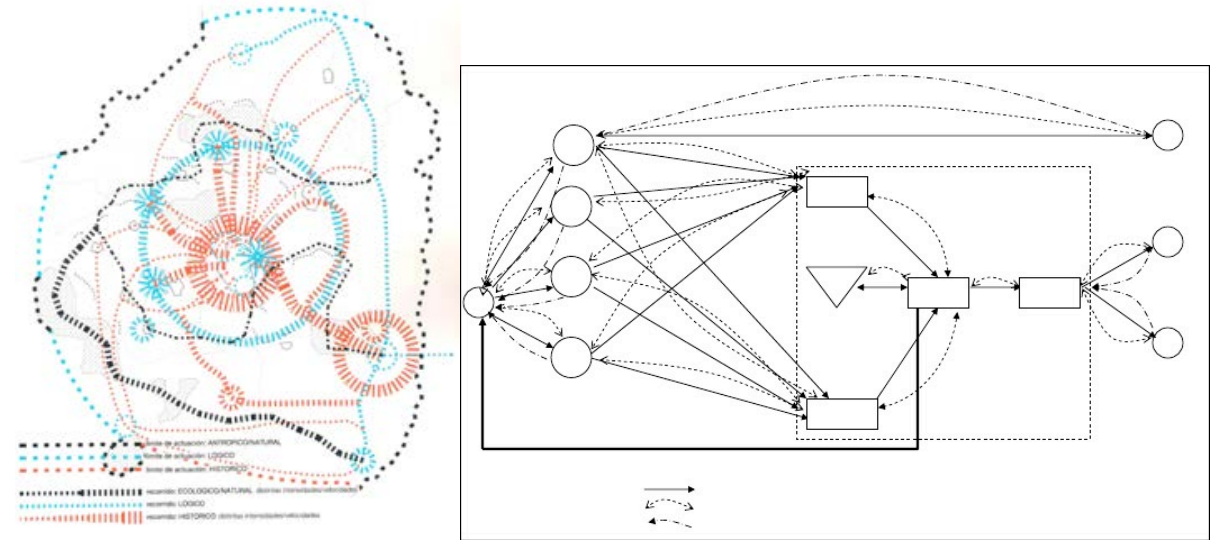

Fig.15. Miradores, entradas, recorridos y limites". Libro "Campo de Batalla Pág. 73

Fig. 16. Plano- esquema de táctica militar.

En conclusión, la estrategia es el plan general para lograr buenos resultados, y la táctica, son las formas o métodos específico que se aplican de acuerdo a las circunstancias ${ }^{30}$. La logística es la combinación de la estrategia y la táctica, infraestructura y medios para llevar a cabo las diferentes acciones. Para algunos expertos, en estas disciplinas, es la logística el elemento más importante de los tres. Ya que sin ella las dos anteriores son insostenibles.

\footnotetext{
${ }^{30}$ Las formaciones y el establecimiento de los puntos de resistencia en los campamentos sin atrincherar. 
Todas estas técnicas se gestionan y se aplican, durante un enfrentamiento sobre un terreno, un espacio y lugar determinado. Las características de estos lugares, como sustento de la batalla, darán lugar a que en la mezcla de ambas las consecuencias producidas en el mismo sean diferentes.

La interpretación de la representación del diseño y la transformación de un lugar bélico, junto con el inseparable vínculo entre la historia, el territorio y el espacio arquitectónico, es la base para comprender el papel de la batalla, de la confrontación y de la fortificación en el proceso de trasformación.

Los procesos de trasformación se considerarán todos como procesos continuos e inseparables, son el mecanismos a modo de superposición para entender cómo un paisaje urbano y arquitectónico cambia a ser un paisaje bélico; cómo la representación del movimiento y la penetración, la observación y el apunte, la fortificación, la defensa y la ofensiva y la destrucción... fueron procesos que sumaron características y proyectos al lugar, incluso a nivel arquitectónico; aunque, en algunos casos, fueran procesos de destrozo o destrucción, no reinterpretados, ya que quedaron solo en los planos, escritos, imágenes y en la memoria. Son procesos de los que nada queda de ellos. ${ }^{31}$

Desde los primero años del siglo XX, los avances técnicos y militares que se dieron lugar influyeron en el modo de entender y utilizar las técnicas estratégicas de guerra. Desde el punto de vista constructivo, arquitectónico, ingeniero y militar la idea clásica de fortificación parmente seguía teniendo su valor, no se destruían, pero se habían dejado de utilizar y por tanto de nuevas inversiones. Tras la Primera Guerra Mundial, y comprobar la nueva artillería, la nuevas técnicas y cambios producidos, hubo dos preocupaciones estratégicamente emergentes: La movilidad de las tropas y la importancia de las defensas costeras. ${ }^{32}$ Esto dio lugar a las mayores fortificaciones en Europa ante la cercanía de una segunda gran guerra que parecía que se esperaba.

\footnotetext{
${ }^{31} \mathrm{~A}$ excepción de pequeños restos o vestigios que se darán detalle más adelante en el epígrafe 3.4

32 Hernández, Rafael Mas. La presencia militar en las ciudades: orígenes y desarrollo del espacio urbano militar en España. Vol. 157. Los Libros de la Catarata, 2003.
} 

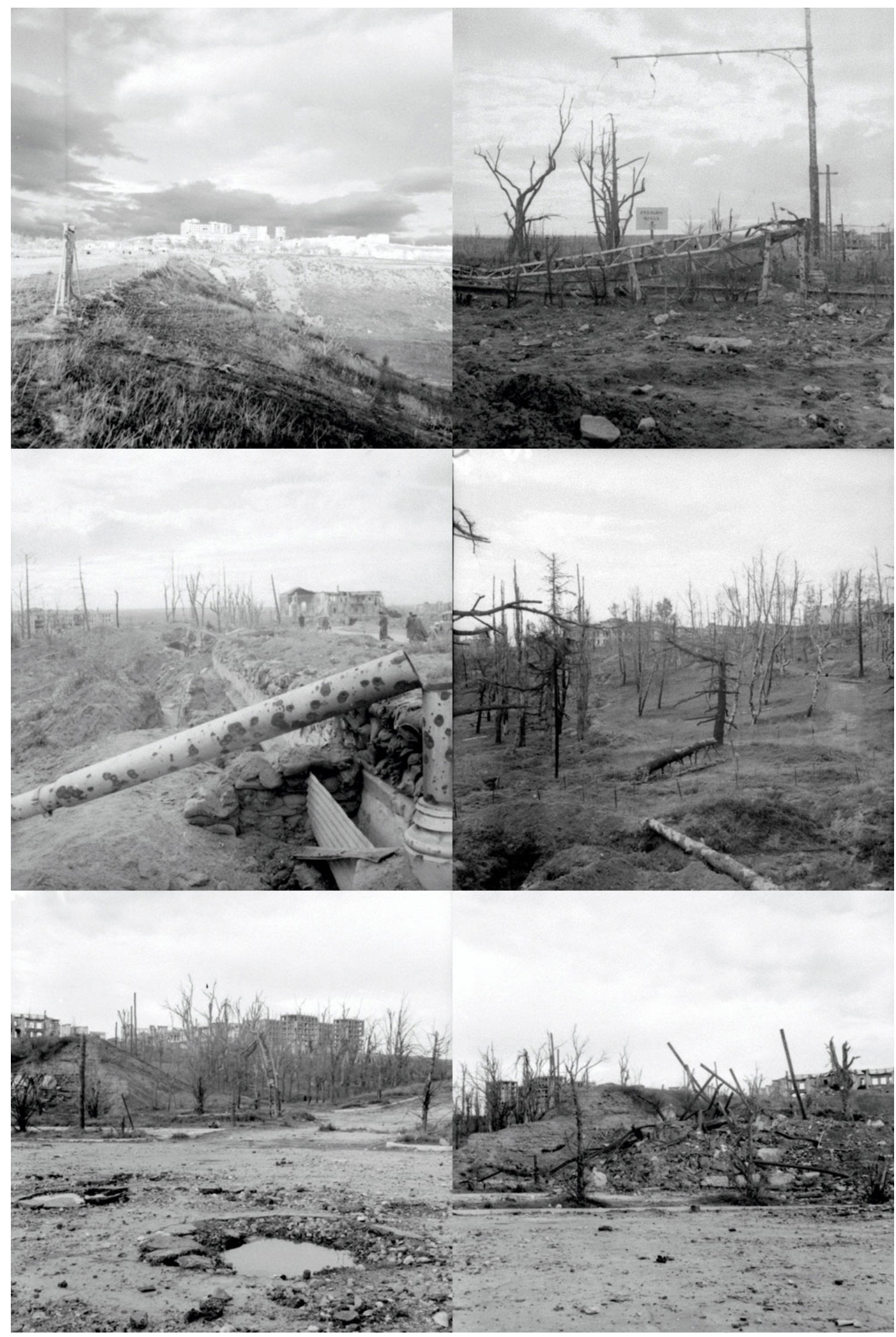

Fig. 17. Fotografías tomadas al finalizar la guerra en 1939 y que pertenece al Archivo General de la Guerra Civil Española del Ministerio de Cultura, de la zona delimitada entre la doble línea enfrentada o "tierra de nadie". La mayoría de ellas pertenecen a la Colección Albert Louis Deschamps. www.madrid1936.es 


\section{C.3.3_ Doble Línea y TierRa de Nadie}

...la visita a un antiguo campo de batalla puede ser mala o buena, según quién te guíe por él. Si dejamos a un lado la demagogia patriotera barata y la otra demagogia estúpida que se niega a aceptar que la Historia y la condición humana está llena de tantas luces como ángulos en sombra, un lugar así puede convertirse, para las generaciones jóvenes, en una excelente escuela de lucidez y tolerancia. ${ }^{33}$

El término "tierra de nadie", "no man's land" o "terrain vague" se considera en la disciplina arquitectónica y urbanística como la zona intermedia entre paisaje y ciudad donde reside la esperanza para una nueva síntesis de vida urbana y de forma urbana34. Según Wilfred Wang el concepto tiene unas raíces históricas arquitectónicas precisas ${ }^{35}$. Sin embargo, en este caso este término conlleva más bien un concepto de espacio y vacío, de límites y muros, de enfrentamiento visual pero no de proyecto y relación con la ciudad.

Las obras de La Ciudad Universitaria continuaron durante el verano de 1936, hasta que la proximidad y cercanía del frente por la confrontación civil, se hizo evidente. Algunas facultades ya estaban terminadas, como las del campus de Medicina y Arquitectura, la Central Térmica o el Edificio de Gobierno, otras en construcción como Físicas, pero solamente una de ellas estaba en funcionamiento, la Facultad de Filosofía y Letras.

El acceso y entrada a Madrid de los nacionales se organizó por el lado izquierdo de la capital. El movimiento envolvente fue inviable ${ }^{36}$, salvo a pequeña escala como ocurrió en la Casa de Campo. El plan general inicial era, tras un ataque de diversión por Carabanchel y Usera, entrar por la Casa de Campo, cruzar el río por la zona del Puente de los Franceses y llegar Madrid pasando por la Carretera del Instituto de Higiene (Avenida Séneca), plaza de La Moncloa y La Cárcel Modelo. La maniobra de flanco izquierdo, por parte de Varela y Franco, era una maniobra efectiva y ya utilizada hasta la saciedad por la tropas coloniales ${ }^{37}$ y aunque la más desfavorable, es la que se utilizó para intentar llegar a la atalaya de la Ciudad Universitaria $^{38}$ y acceder a la capital. Las columnas Castejón, Asensio, Delgado Serrano, Barrón y Tello, tan conocidas todas por los planos que explican este

\footnotetext{
33 Cita de Arturo Pérez-Reverte.

34 Palabra de Steven Hall en el articulo Tierra de Nadie- Espacios inaprensibles. Revista Quaderns Fórum Internacional 214 p. 98.

35 Ibídem p. 98

${ }^{36}$ La dirección del avance desde Toledo, la premura y la escasez de efectivos.

${ }^{37}$ En este caso el General Varela ya la había utilizado durante su avance hacia Madrid con las columnas que tenía al mando.

38 Forma con la Pilar Chías describe la posición y la forma de los terrenos como metáfora, en su Tesis. La Ciudad Universitaria de Madrid: Planeamiento y Realización 1983 p. 57.
} 
ataque gráficamente, fueron las que lo llevaron acabo. Pero varios hechos produjeron un cambio. ${ }^{39}$ La noche y la información extra hizo a los republicanos reorganizarse. Reorganización que favoreció la defensa de Madrid, por parte de Miaja y Rojo.

...estaban obligados a realizar el empeño pues moralmente no podían no intentarlo, estratégicamente no tenían ni otra masa de maniobra ni otro objetivo decisivo... tácticamente no podían elegir el lugar por donde intentarlo... 40

Los lugares que en su génesis habían sido realizados bajo una ley compositiva y ordenadora, desaparecieron en menos de veinte días, asignándoles un uso totalmente ajeno e impropio. Lo que era un recinto o lugar del saber, zona de espacios verdes y relaciones ${ }^{41}$ de uso docente se trasformó a la vez que sus edificaciones, en un lugar físico diferente, al principio provisional y desorganizado, pero debido a la estabilización de los hechos, en un nuevo lugar condensado, continuo y asegurado, con la claro intención codificada de proteger y defender.

- Las tropas nacionales se hacían llamar sí mismas "Ejército liberador" 42 o "Nacionales"43, al igual que las tropas republicanas se llamaban "El Bando Leal" o el "Ejército defensor o democrático" a sí mismos.

- Para los republicanos, el bando nacional eran "los fascistas", "bando sublevado" o "bando opresor", del mismo modo, que los franquistas se referían a los republicanos como "rojos", "marxistas", "bolcheviques", "comunistas"44 incluso "separatistas".

Tras veinte días de combate, la situación quedaría estabilizada hasta el final de la confrontación en una forma fija y prácticamente inalterable. Las tropas nacionales que habían accedido con la idea de alcanzar Madrid ocuparon la "bolsa", "cuña" o "península" que quedaba conectada a la Casa de Campo solamente por una plataforma o puente llamada "la Pasarela de la Muerte"; los edificios a los que accedieron fueron el Palacete, Casa de Labor, Arquitectura, Casa Velázquez y La

\footnotetext{
${ }^{39}$ Conocer la orden de avance por parte de los republicanos en la tanqueta de un capitán del bando nacional.

40 Calvo González Regueral, Fernando. La Guerra civil en la Ciudad Universitaria. La Librería. p.27.

${ }^{41}$ La mayoría de las edificaciones casi terminadas, o algunas de sus infraestructuras o viales mas importante estaban recién estrenadas o a punto de realizarse

${ }^{42}$ Tras la guerra civil, el Nuevo Régimen atribuyó las destrucciones a los hombres y mujeres que resistían el acoso del ejecito "liberador", porque la idea era liberar Madrid y también a España del Régimen de la Republica.

43 Termino costumbrista originado en la "Junta de defensa nacional" creada en Burgos al principio de la guerra. Por el bando sublevado.

${ }^{44}$ Con independientemente de su pertenencia o no al Partido Comunista. El bando Republicano tuvo un gran variedad de ideologías que llevaba a la confusión a que pertenecía cada miembro. 
Escuela de Agrónomos, en los de orientación más norte, hasta llegar al Clínico (punto más alto), y posteriormente al Asilo de Santa Cristina, Instituto de Higiene o zona de Residencias, en la orientación sur.

En el resto de edificios docentes -Paraninfo y campus de Ciencias- junto con la línea que se unía al Parque del Oeste se encontraban las fuerzas republicanas, a una distancia entre $50 \mathrm{~m}$ y $10 \mathrm{~m}$ en algunos puntos, conformando entre ellas la llamada "Tierra de Nadie".

No se puede negar que las tierras y las edificaciones de La Ciudad Universitaria después de los combates que empezaron en 1936 y terminaron en 1939 quedaron arrasadas. Tres años, donde las tropas nacionales, ocuparon los terrenos dentro de la zona cerrada (La cabeza de Galgo) al otro lado del río Manzanares, frente a las tropas Republicanas, que se apostaban bajo terrenos y construcciones mas próximos a la ciudad o en zonas periféricas alrededor de la posición de las tropas enemigas. 45

La defensa de Madrid se basó en gran parte en la resistencia, en la cornisa perimetral de la ciudad debido, principalmente, a la estabilización del frente en La Ciudad Universitaria. Una situación que una vez pasados los primeros días de batalla se tradujo en un proyecto completo de urbanismo y fortificación por medio de refugios, casamatas, caminos y trincheras, y con las trasformación de todas sus edificaciones y facultades como baluartes dentro del sistema de protección.

... A punto de ser inaugurada para la fiesta de la Hispanidad del año 36, la Ciudad Universitaria iba a cambiar muy lamentablemente la pluma por el sable, convirtiéndose pronto su recinto en un paisaje desolado de cráteres, embudos, trincheras, casamatas y ruinas $^{46}$.

Su forma variaba a lo largo del ámbito, se estrangulaba y se estrechaba en función de las posiciones de los edificios, del apoyo de la topografía y de la cercanía de los frentes. La zona "tierra de nadie" podía llegar a ser de escasamente $20 \mathrm{~m}$ de distancia, como sucedía en la zona del Clínico o del Parque del Oeste, o de zonas más amplia y distantes, como la que se daba entre el Palacete y el subsector de zona de Filosofía y Letras.

\footnotetext{
45 Es fácil identificar claramente, cuando se lee un texto, las ideas que defiende el escritor. En cualquier tipo de documento de investigación, y siendo este trabajo una tesis, la ideología debe quedar a un lado para dar una respuesta científica, contrastada y demostrable de los hechos y teorías que se explican o se presentan como un nuevo conocimiento con fuentes y documentación lo más veraz posible. La línea que separa el pensamiento no científico y el pensamiento científico es: que el primero no exige demostración, mientras el segundo tiene en ella su punto inicial de partida. De la demostración depende que un pensamiento tenga o no validez de investigación. ${ }^{46}$ Calvo González Regueral, Fernando. La Guerra civil en la Ciudad Universitaria. La Librería. p.50.
} 
Poco o nada quedaría y se conservaría de todo aquello, solo la reinterpretación y la imaginación que se podría hacer como una radiografía del lugar, gracias a los planos, fotografías, documentos y relatos que disponemos.

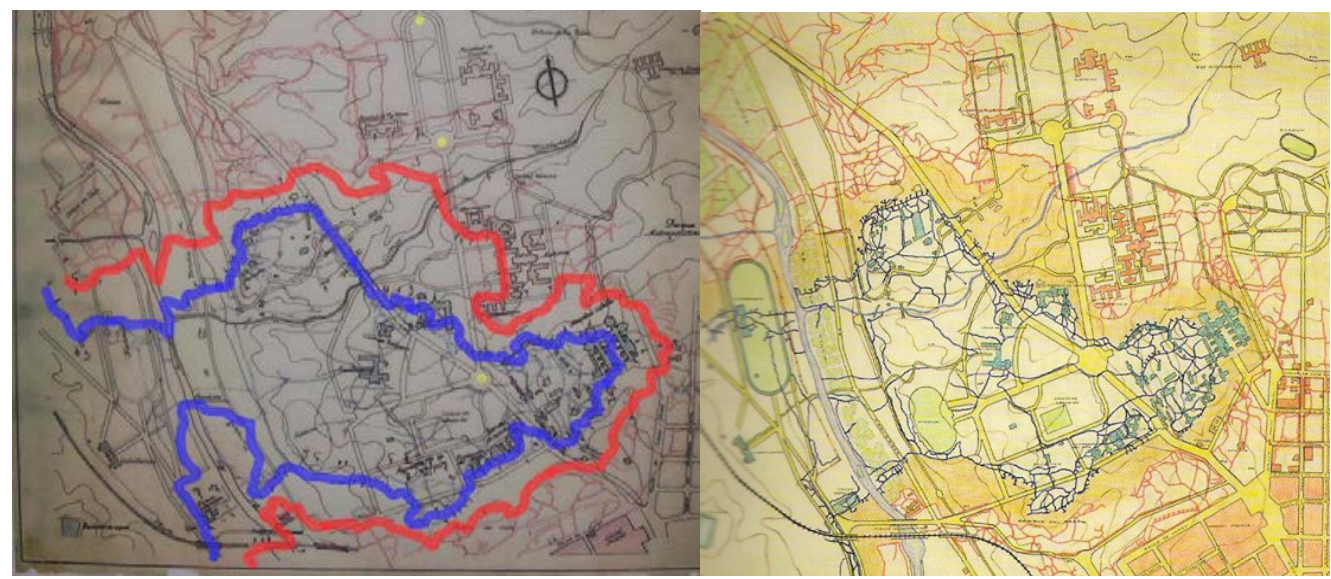

Fig. 18,19. Planos de trinchera y frentes. (modificado por el autor y recorte del original) (Archivo General Militar de Ávila (AGMA).-)

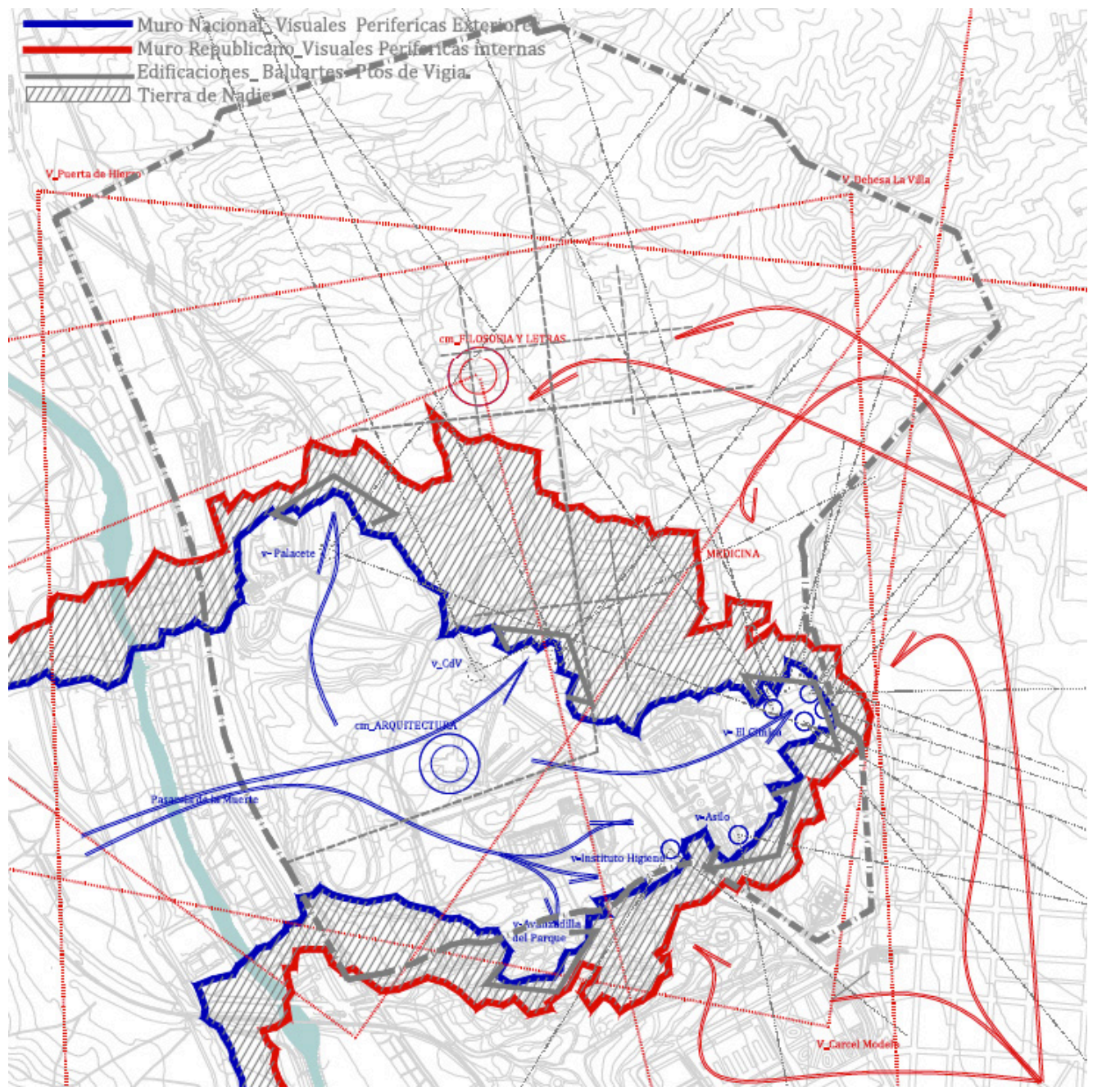

Fig. 20. Muros y Visuales. Proceso de Trasformación p.4 


\section{C.3.3.1 FISONOMIA TERRITORIAL. FRAGMENTACIÓN DEL SUELO}

El terreno que había sido modificado en grandes plataformas en la zona más próxima a la ciudad, bajo la cornisa perimetral, para la realización de las obras bajo la mirada, necesaria y funcional, de ingenieros, arquitectos y urbanistas; pasaría ahora a ser estudiado bajo otros condicionantes o necesidades, con una mirada militar, en la que prevalecía la aplicación de técnicas en beneficio del valor ofensivo y defensivo más que la mirada formal, estilística, funcional o compositiva que había primado antes.

Como dice Michael Laurie en su libro sobre las "Introducción a la arquitectura del paisaje", el suelo es un una de los bienes mas importantes que hay en el mundo y es necesario su valoración, planificación y conservación. El suelo se convierte en paisaje cuando se describe y se percibe en términos relacionados a su fisiográfica o característica-estructura ambiental. El paisaje cambia cuando cambian estas propiedades y con la influencia histórica del hombre. Esta influencia histórica en nuestro caso de estudio se amplió por esa trasformación de carácter bélico, analizándola como la visión táctica de actuación en el lugar, la estrategia de fortificación, aplicándose ambas sobre la fisiografía del lugar.

Nuestra operaciones dejaron de ser regidas por el Arte Militar y lo fueron por la atracción sentimental que ejercía Madrid [...] En Méntrida cerramos los libros de tácticas y abrimos los del corazón [...] No pueden enjuiciarse las operaciones militares de este periodo si se desconoce u olvida este importante dato psicológico. ${ }^{47}$

Las necesidades de comunicación y obtención a su vez de posiciones estables en el campo de batalla de la Universitaria originó una fragmentación completa del suelo proyectado. Una fragmentación más condensada y lineal, por el poco espacio cerrado, y otra más extensiva y radial porque aglutinaba todo lo extenso de la ciudad como conexión.

La proyección de las trincheras y los ramales de comunicación se planearon y proyectaron, de manera rápida e improvisada en los primeros momentos, pero en gradación y orden más tarde. Toda una serie de galerías, caminos, trincheras y ramales en gradación de tres bandas o niveles, que rompieron y fragmentaron todo el terreno. Una gran ciudad de calles exteriores y subterráneas de unas dimensiones y construcción, en un bando más burdas, por la precariedad de su material, en otra más definidas y bien ejecutadas, por contar con la protección y el espacios necesario.

${ }^{47}$ Kindelán, Alfredo. Mis cuadernos de guerra (1936-1939). Planeta. 1982 

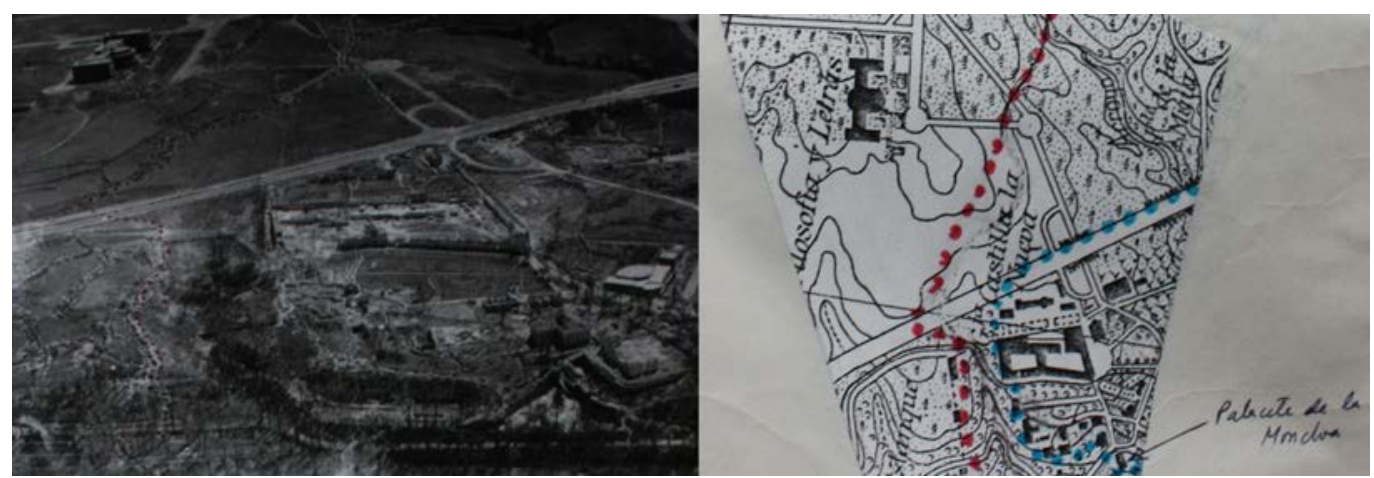

Fig.21. Foto y plano de zona de trinchera en zona del Palacete. AGHEA
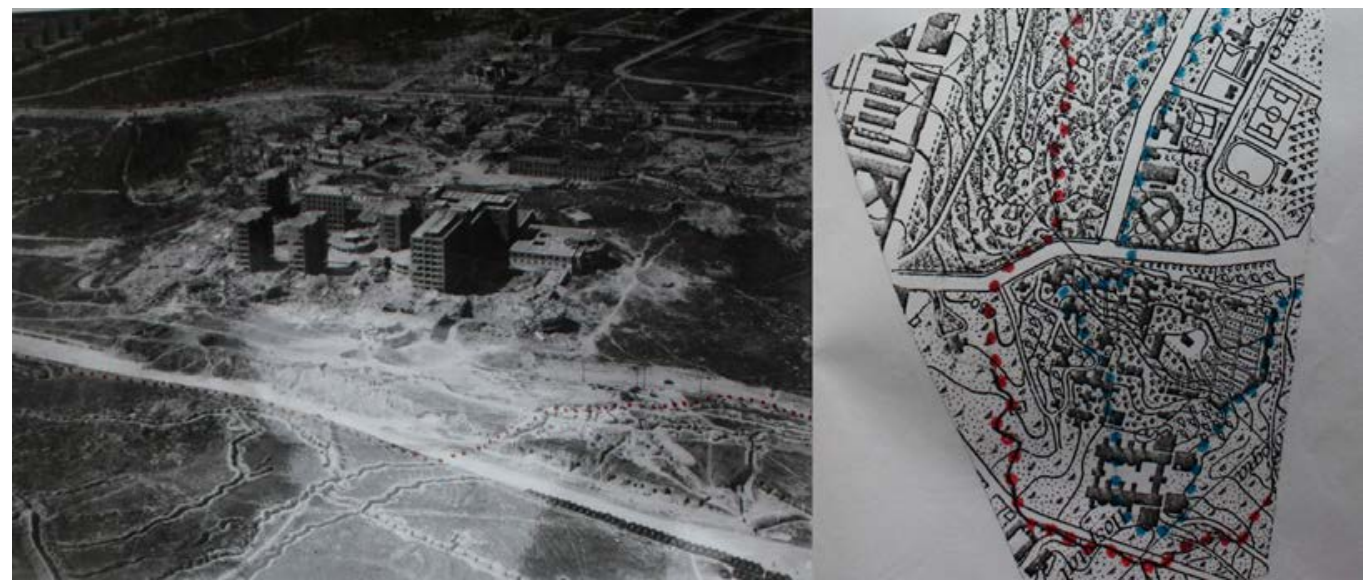

Fig.22. Foto y plano de zona de trinchera en zona de El Clínico. AGHEA
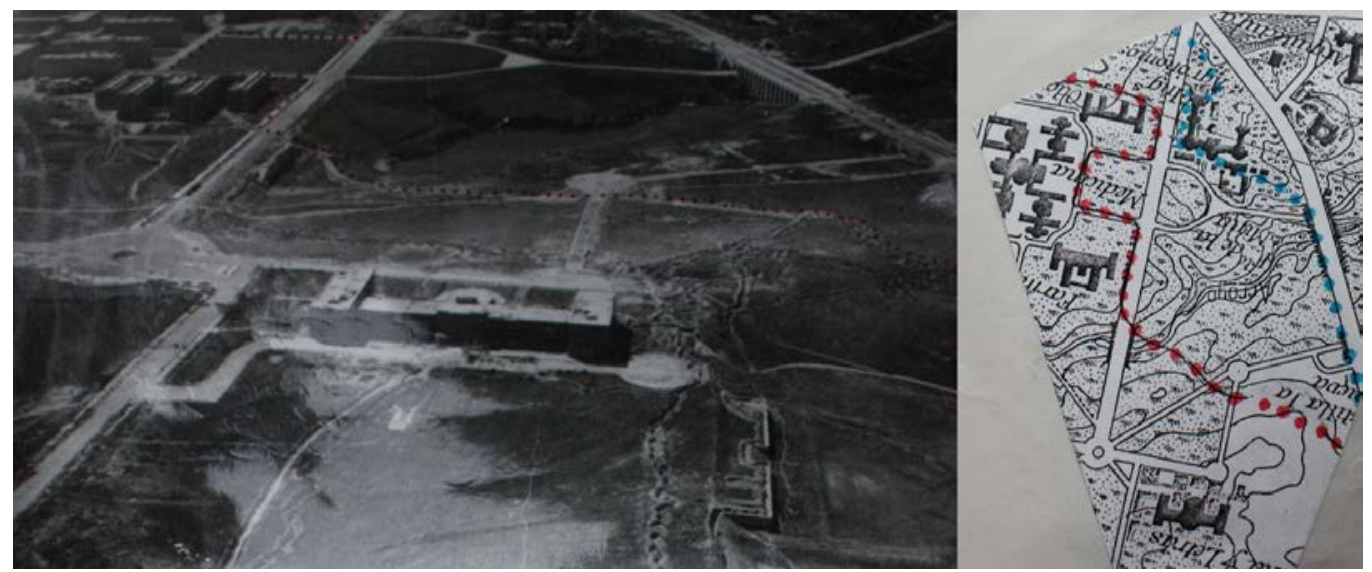

Fig.23. Foto y plano de zona de trinchera en Filosofía y Letras. AGHEA 


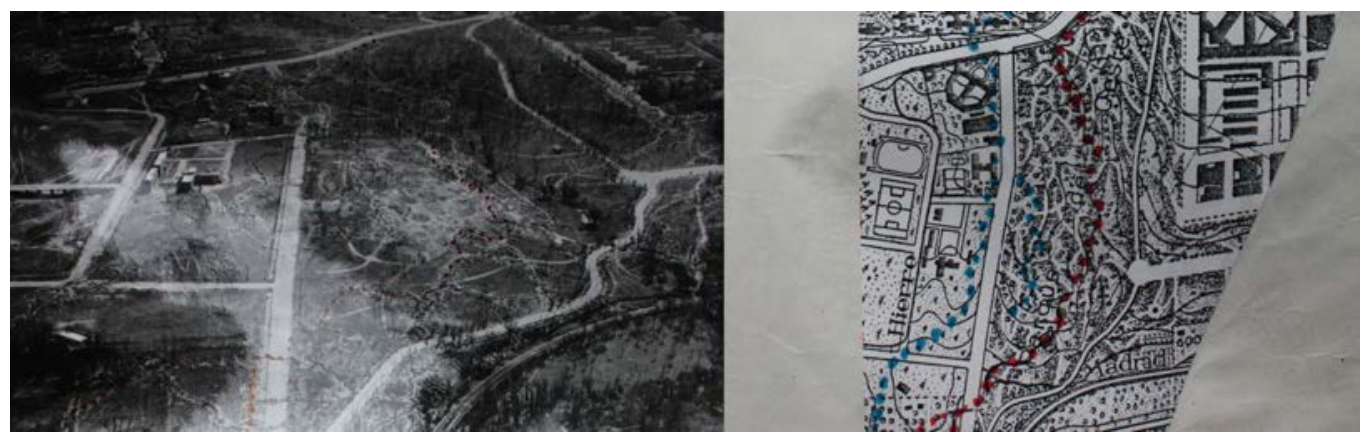

Fig.24. Foto y plano de zona de trinchera en Parque del Oeste. AGHEA
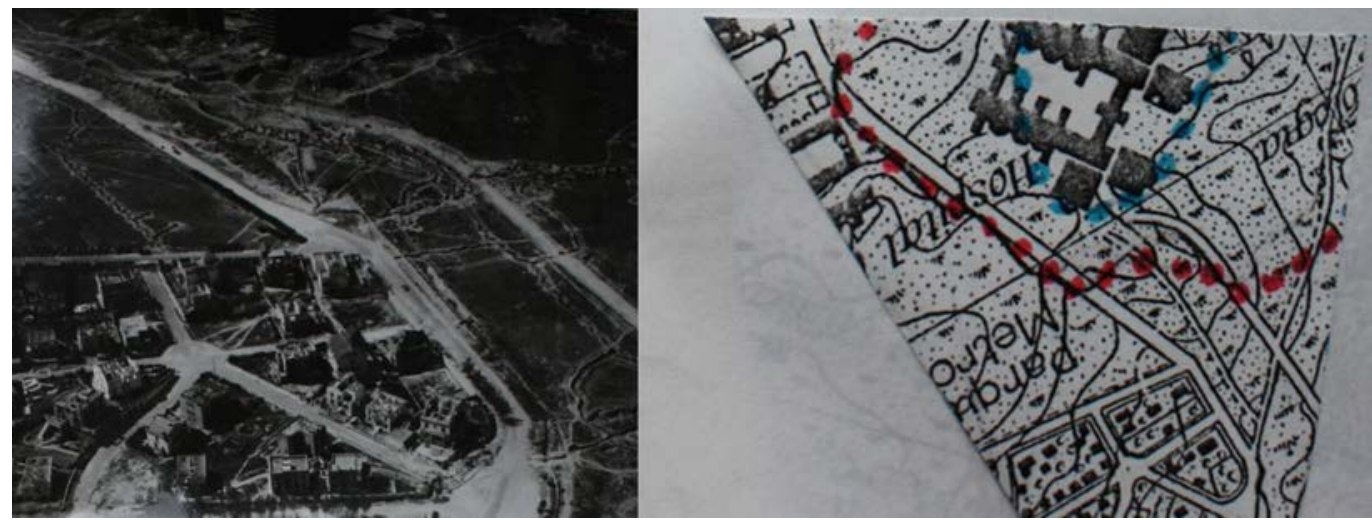

Fig.25. Foto y plano de zona de trinchera en zona de la Colonia Metropolitana. AGHEA
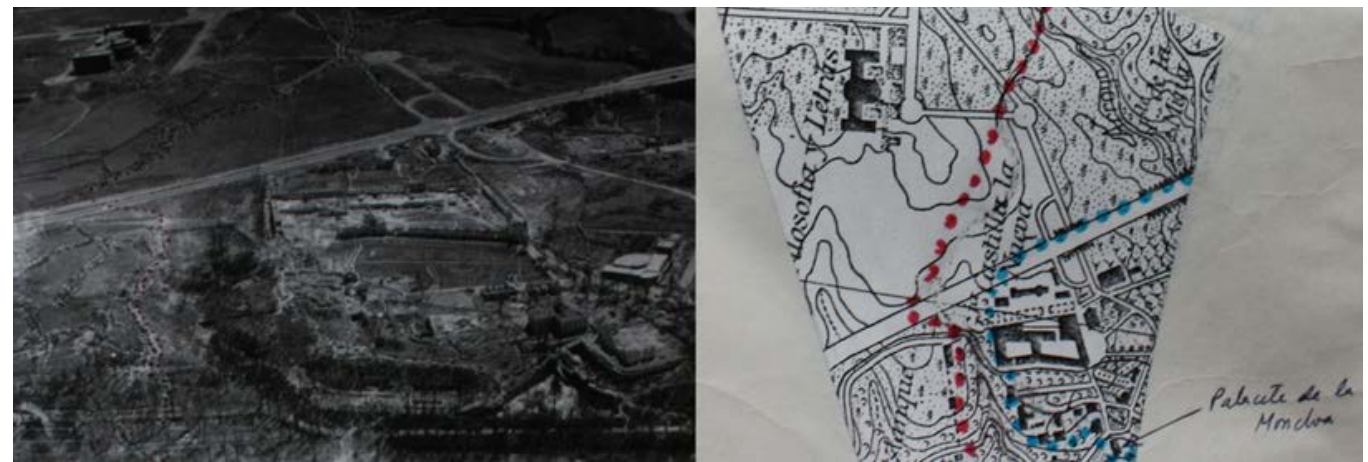

Fig.26. Foto y plano de zona de trinchera en Filosofía y Letras y Palacete AGHEA

Las trincheras y ramales configuraban un laberinto "ordenado" y "complicado" creando un red de comunicaciones entre las edificaciones, posiciones y puntos en que se subdividían cada centro de resistencia o sector de zona. Era una doble o incluso triple línea que se comunicaba con otras perpendiculares, llamadas ramales, dando lugar a varios niveles y profundidades respecto a la primera. La forma mas rápida y efectiva de su realización, y para favorecer la accesibilidad a casi todos los puntos cardinales en el terreno, era hacer una línea lo mas estrecha y lo mas profunda posible, prácticamente en sentido espacial vertical. 


\section{C.3.3.2_FISONOMIA ARQUITECTONICA.}

EXTERIOR DE LAS CONSTRUCCIONES.

El suelo, fue como un gran estrato donde se fragmentó y horadó más que se construyó. Un suelo con unas características fisiológicas que debido a sus características formales, extensión, altura y a sus grandes construcciones que allí esperaban permitió y absorbió que todas ellas formaran parte de todo;, un proyecto dual, un sistema dual de fortificación enfrentadas y yuxtapuesta. Una trama de caminos, ramales y trincheras que se comunicaban con edificaciones, cada una de ellas como zona de punta de flecha, conformando toda una línea o muro continuo. Continuidad y discontinuidad donde las edificaciones siendo blanco visible y claro, eran sus interiores las que servirían de resguardo y nodo estratégico.

- Las zonas bajas, sótanos y zonas bajo nivel de tierra servían de resguardo y protección. Los zócalos de piedra y sus huecos casi rasantes con el suelo fueron los mas utilizados y a la vez dañados.

- Las ventanas antes utilizadas como entradas de luz y ventilación, fueron la mayoría tapiadas y cerradas, solo algunas se utilizarían como punto de visual desde donde observar y atacar al enemigo. ${ }^{48}$

- Las entradas a las construcciones, centradas, simétricas y sobre grandes zócalos, ya no tenían ni el valor funcional ni de uso previa. Sus amplias escaleras de granito, grandes vanos interiores dejaron de ser el punto neurálgico de la edificación.

- Las estructuras de grandes pórticos de vigas y pilares de hormigón, y la buena construcción de fabrica de ladrillo y piedra, tomaron, sin haber sido pensado para ello, una importancia y valor circunstancial por los acontecimientos que se dieron lugar frente a sus muros. Parecía como si aquella envergadura, contundencia arquitectónica, y limpieza de volúmenes hubieran sido previamente proyectados a priori para el fin y el uso a los que ahora se dedicaban.

\footnotetext{
48 Fueron muchas las fotos tomadas desde ventanas Alguna con mas o menos intención o profundidad, otras como futuro material de haber sido el captor de los cambios sufrido en los edificios por la artillería. Fotografías que tras la edificación dañada o destruida, se rodean o complementa con un fondo de terrenos que originan el paisaje fotografiado que ya no lunar, es de destrucción y abandono. 